Prepared in cooperation with the Minnesota Department of Natural Resources

\title{
Water Quality and Algal Community Dynamics of Three Sentinel Deepwater Lakes in Minnesota Utillizing GE-QUAL-W/2 Models
}

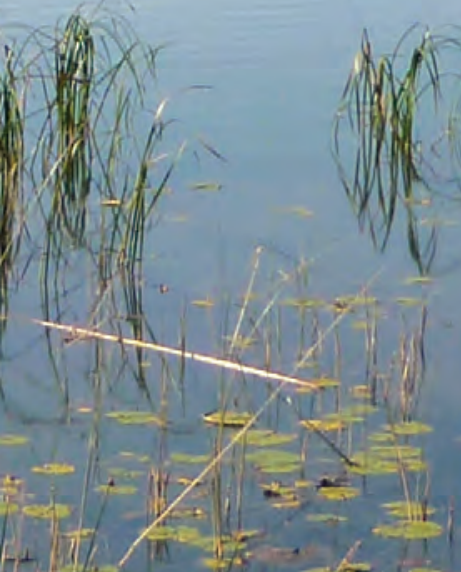

-Sciêntific Investigations Report 2014-5066

U.S. Department of the interior

U.S. Geologtgal suryey 
Cover photograph. View across Elk Lake, September 2011 (photograph by Richard L. Kiesling, U.S. Geological Survey). 


\section{Water Quality and Algal Community Dynamics of Three Sentinel Deepwater Lakes in Minnesota Utilizing CE-QUAL-W2 Models}

By Erik A. Smith, Richard L. Kiesling, Joel M. Galloway, and Jeffrey R. Ziegeweid

Prepared in cooperation with the Minnesota Department of Natural Resources

Scientific Investigations Report 2014-5066 


\title{
U.S. Department of the Interior SALLY JEWELL, Secretary
}

\section{U.S. Geological Survey Suzette M. Kimball, Acting Director}

\author{
U.S. Geological Survey, Reston, Virginia: 2014
}

For more information on the USGS - the Federal source for science about the Earth, its natural and living resources, natural hazards, and the environment, visit http://www.usgs.gov or call 1-888-ASK-USGS.

For an overview of USGS information products, including maps, imagery, and publications, visit http://www.usgs.gov/pubprod

To order this and other USGS information products, visit http://store.usgs.gov

Any use of trade, firm, or product names is for descriptive purposes only and does not imply endorsement by the U.S. Government.

Although this information product, for the most part, is in the public domain, it also may contain copyrighted materials as noted in the text. Permission to reproduce copyrighted items must be secured from the copyright owner.

Suggested citation:

Smith, E.A., Kiesling, R.L., Galloway, J.M., and Ziegeweid, J.R., 2014, Water quality and algal community dynamics of three deepwater lakes in Minnesota utilizing CE-QUAL-W2 models: U.S. Geological Survey Scientific Investigations Report 2014-5066, 73 p., http://dx.doi.org/10.3133/sir20145066.

ISSN 2328-0328 (online 


\section{Acknowledgments}

Funding for this study was provided by a grant from the Environmental and Natural Resource Trust Fund of Minnesota to the Minnesota Department of Natural Resources and by the U.S. Geological Survey Cooperative Water Program. This report presents a compilation of information supplied by several agencies and individuals. The authors would like to thank the Minnesota Department of Natural Resources and Minnesota Pollution Control Agency for assistance with field aspects of the study. The authors would like to thank Dr. Scott Wells, Portland State University, for assistance with setting up the CE-QUAL-W2 model. Ray Valley, formerly of the Minnesota Department of Natural Resources, is acknowledged for support of this study. Steve Heiskary of the Minnesota Pollution Control Agency is acknowledged for his technical review of the report. Additionally, Brian Herwig and Tim Cross of the Minnesota Department of Natural Resources are acknowledged for courtesy reviews of the manuscript.

Kasey Hutchinson of the U.S. Geological Survey is acknowledged for his technical review of the report. Sarah Elliott, Andrew Berg, Brent Mason, and Emily Resseger of the U.S. Geological Survey are acknowledged for assistance with office and field aspects of the study. 



\section{Contents}

Acknowledgments ..................................................................................................................ii

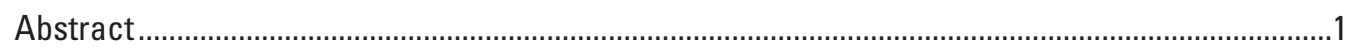

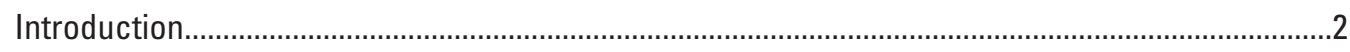

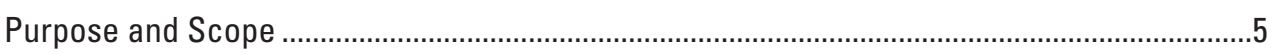

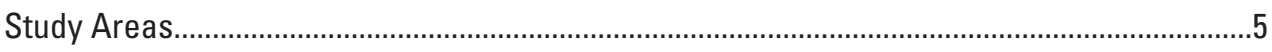

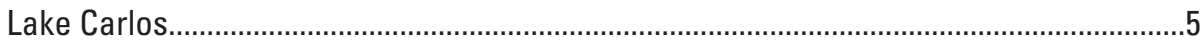

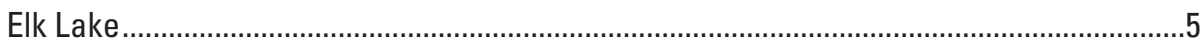

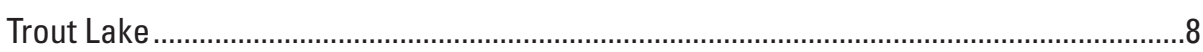

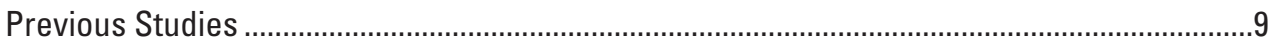

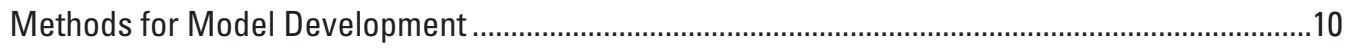

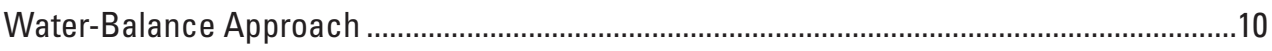

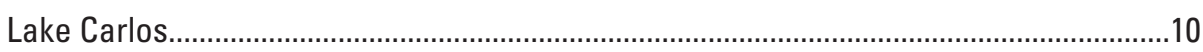

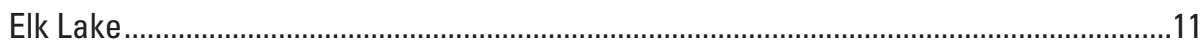

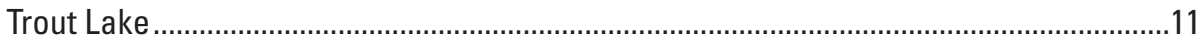

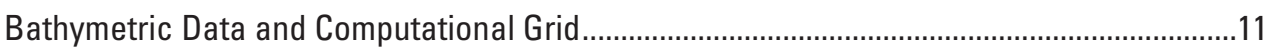

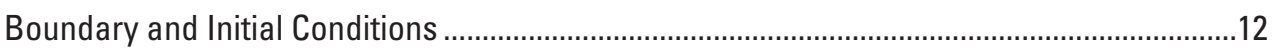

Hydraulic and Thermal Boundary Conditions ............................................................16

Lake Carlos...................................................................................................

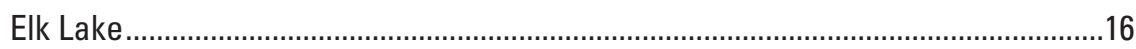

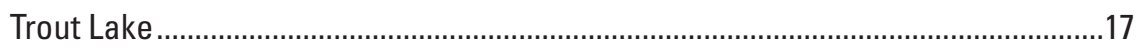

Water-Quality Data Collection, Vertical Profiles and Laboratory Analyses....................17

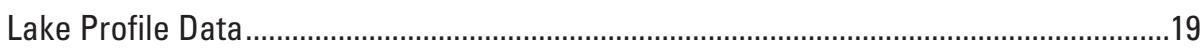

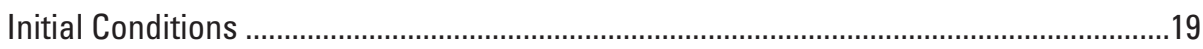

Chemical Boundary Conditions ................................................................................19

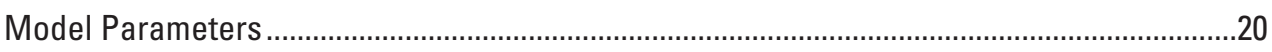

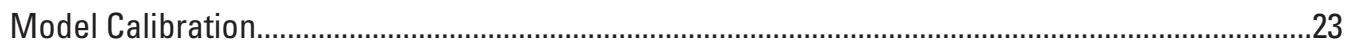

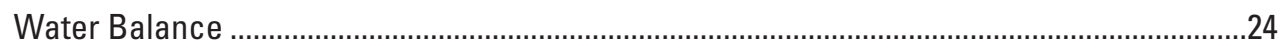

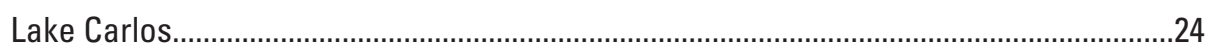

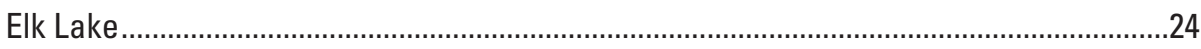

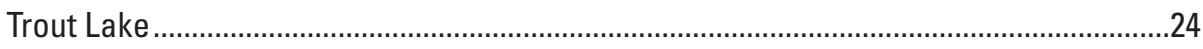

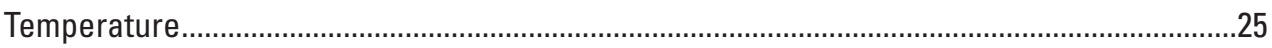

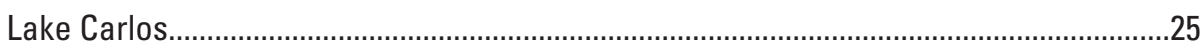

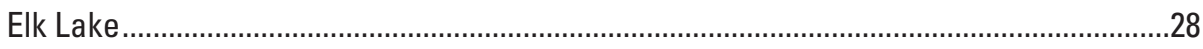

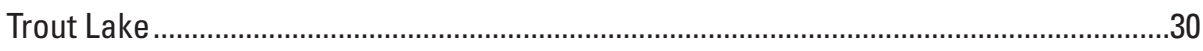

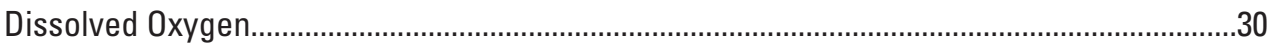

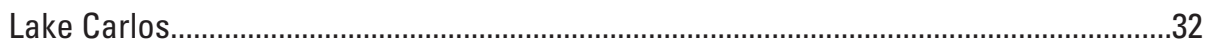

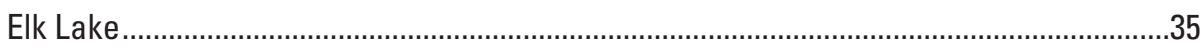

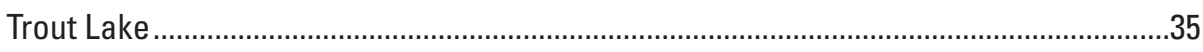

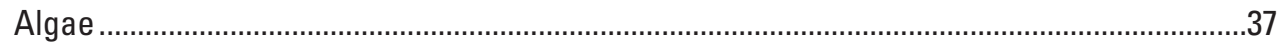

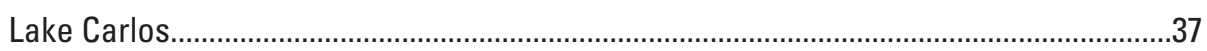

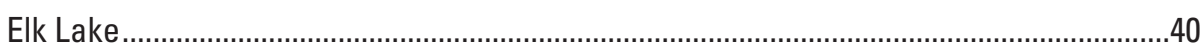

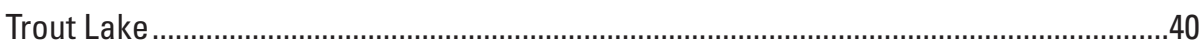




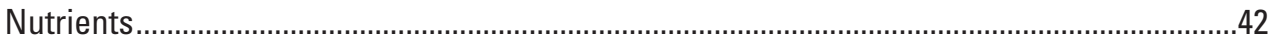

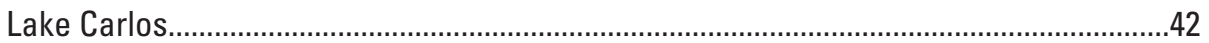

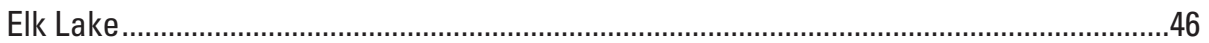

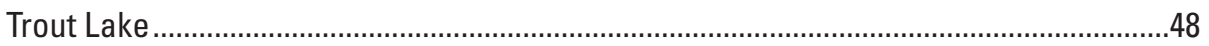

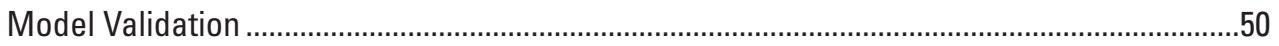

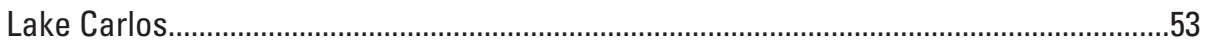

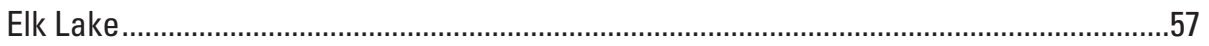

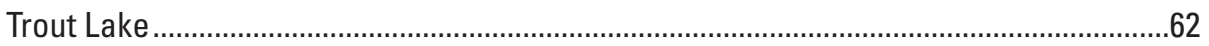

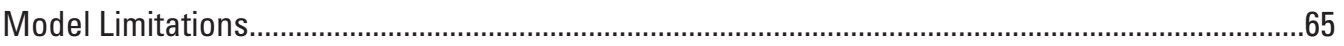

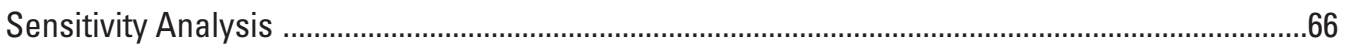

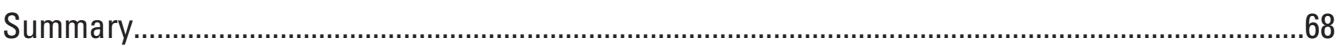

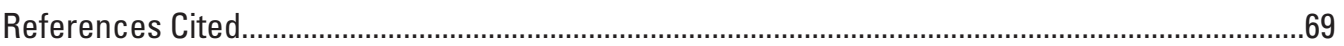

\section{Figures}

1. Map showing major ecoregions and the three lakes for this study ...................................

2. Map showing location of water-quality sampling sites of Lake Carlos, Minnesota .........6

3. Map showing location of water-quality sampling sites of Elk Lake, Minnesota.................7

4. Map showing location of water-quality sampling sites of Trout Lake, Minnesota............9

5. Graphs showing lake volume and lake-surface area to water-surface elevation for Lake Carlos using the measured bathymetry and as represented by the model grid...

6. Graphs showing lake volume and lake-surface area to water-surface elevation for Elk Lake using the measured bathymetry and as represented by the model grid

7. Graphs showing lake volume and lake-surface area to water-surface elevation for Trout Lake using the measured bathymetry and as represented by the model grid

8. Computational grid for the CE-QUAL-W2 model for Lake Carlos ...................................13

9. Computational grid for the CE-QUAL-W2 model for Elk Lake.........................................14

10. Computational grid for the CE-QUAL-W2 model for Trout Lake......................................15

11. Graph showing simulated and measured water-surface elevations for Lake Carlos, April 20 to November 10, 2010.

12. Graph showing simulated and measured water-surface elevations for Elk Lake,

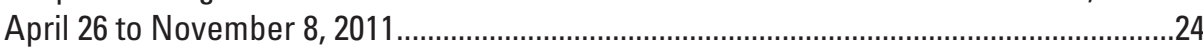

13. Graph showing simulated and measured water-surface elevations for Trout Lake, April 28 to October 21, 2010

14. Graph showing simulated and measured water temperature for the epilimnion and hypolimnion at Kecks Point for Lake Carlos, April 20, 2010, to November 10, 2010 , with quantities of absolute mean error and root mean square error

15. Graphs showing simulated and measured water temperature at Kecks Point in Lake Carlos for 15 dates in 2010, with quantities of absolute mean error and root mean square error.

16. Graphs showing simulated and measured water temperature for the epilimnion and hypolimnion at the south basin hole in Elk Lake, April 26, 2011, to November 8, 2011, with quantities of absolute mean error and root mean square error...... 
17. Graphs showing simulated and measured water temperature at the south basin hole in Elk Lake for 15 dates in 2011, with quantities of absolute mean error and root mean square error.

18. Graph showing simulated and measured water temperature for the epilimnion and hypolimnion at the north basin hole in Trout Lake, April 28, 2010, to October 21,2010 , with quantities of absolute mean error and root mean square error

19. Graphs showing simulated and measured water temperature at the north basin hole in Trout Lake for 14 dates in 2010, with quantities of absolute mean error and root mean square error.

20. Graphs showing simulated and measured dissolved oxygen concentration at Kecks Point in Lake Carlos for 11 dates in 2010, with quantities of absolute mean error and root mean square error.

21. Graphs showing smulated and measured dissolved oxygen concentration at the south basin hole in Elk Lake for 15 dates in 2011, with quantities of absolute mean error and root mean square error.

22. Graphs showing continuous simulated and measured dissolved oxygen concentration at south basin hole in Elk Lake for three depths, with quantities of absolute mean error and root mean square error, April 26, 2011, to November 8 , 2011

23. Graphs showing simulated and measured dissolved oxygen concentration at the north basin hole in Trout Lake for 15 dates in 2010, with quantities of absolute mean error and root mean square error.

24. Graphs showing simulated algal group distributions for three model segments for Lake Carlos, April 20, 2010, to November 10, 2010.

25. Graphs showing simulated and measured chlorophyll a concentrations for three model segments in Lake Carlos, April 20, 2010, to November 10, 2010, with quantities of absolute mean error and root mean square error

26. Graphs showing simulated algal group distributions for two depths at the south basin hole in Elk Lake, April 26, 2011, to November 8, 2011

27. Graphs showing simulated and measured chlorophyll a concentrations for two depths at the south basin hole in Elk Lake, April 26, 2011, to November 8, 2011, with quantities of absolute mean error and root mean square error

28. Graphs showing simulated algal group distributions for two depths at the north basin hole in Trout Lake, April 28, 2010, to October 21, 2010

29. Graphs showing simulated and measured chlorophyll a concentrations for two depths at the north basin hole in Trout Lake, April 28, 2010, to October 21, 2010, with quantities of absolute mean error and root mean square error

30. Graphs showing simulated and measured ammonia concentrations for three epilimnetic model segments and a hypolimnetic model segment for Lake Carlos, April 20, 2010, to November 10, 2010, with quantities of absolute mean error and root mean square error.

31. Graphs showing simulated and measured nitrate plus nitrite concentrations for three epilimnetic model segments and a hypolimnetic model segment for Lake Carlos, April 20, 2010, to November 10, 2010, with quantities of absolute mean error and root mean square error.

32. Graphs showing simulated and measured orthophosphorus concentrations for three epilimnetic model segments and a hypolimnetic model segment for Lake Carlos, April 20, 2010, to November 10, 2010, with quantities of absolute mean error and root mean square error. 
33. Graphs showing simulated and measured total nitrogen concentrations for three epilimnetic model segments and a hypolimnetic model segment for Lake Carlos, April 20, 2010, to November 10, 2010, with quantities of absolute mean error and root mean square error.

34. Graphs showing simulated and measured phosphorus concentrations for three epilimnetic model segments and a hypolimnetic model segment for Lake Carlos, April 20, 2010, to November 10, 2010, with quantities of absolute mean error and root mean square error.

35. Graphs showing simulated and measured ammonia concentrations for two depths at the south basin hole in Elk Lake, April 26, 2011, to November 8, 2011, with quantities of absolute mean error and root mean square error.

36. Graphs showing simulated and measured nitrate plus nitrite concentrations for two depths at the south basin hole in Elk Lake, April 26, 2011, to November 8, 2011 , with quantities of absolute mean error and root mean square error

37. Graphs showing simulated and measured orthophosphorus concentrations for two depths at the south basin hole in Elk Lake, April 26, 2011, to November 8, 2011, with quantities of absolute mean error and root mean square error.

38. Graphs showing simulated and measured total nitrogen concentrations for two depths at the south basin hole in Elk Lake, April 26, 2011, to November 8, 2011, with quantities of absolute mean error and root mean square error.....

39. Graphs showing simulated and measured total phosphorus concentrations for two depths at the south basin hole in Elk Lake, April 26, 2011, to November 8, 2011 , with quantities of absolute mean error and root mean square error

40. Graphs showing simulated and measured ammonia concentrations for two depths at the north basin hole in Trout Lake, April 28, 2010, to October 21, 2010, with quantities of absolute mean error and root mean square error...

41. Graphs showing simulated and measured nitrate plus nitrite concentrations for two depths at the north basin hole in Trout Lake, April 28, 2010, to October 21, 2010 , with quantities of absolute mean error and root mean square error

42. Graphs showing simulated and measured orthophosphorus concentrations for two depths at the north basin hole in Trout Lake, April 28, 2010, to October 21, 2010 , with quantities of absolute mean error and root mean square error

43. Graphs showing simulated and measured total nitrogen concentrations for two depths at the north basin hole in Trout Lake, April 28, 2010, to October 21, 2010, with quantities of absolute mean error and root mean square error.....

44. Graphs showing simulated and measured total phosphorus concentrations for two depths at the north basin hole in Trout Lake, April 28, 2010, to October 21, 2010 , with quantities of absolute mean error and root mean square error

45. Graph showing simulated and measured water temperature for the epilimnion and hypolimnion at Kecks Point in Lake Carlos, March 14, 2011, to September 28, 2011, with quantities of absolute mean error and root mean square error

46. Graphs showing simulated and measured water temperature at Kecks Point in Lake Carlos for 13 dates in 2011, with quantities of absolute mean error and root mean square error.

47. Graphs showing simulated and measured dissolved oxygen concentration at Kecks Point in Lake Carlos for eight dates in 2011, with quantities of absolute mean error and root mean square error.

48. Graphs showing simulated and measured chlorophyll a concentrations for three model segments for Lake Carlos, March 14, 2011, to September 28, 2011, with quantities of absolute mean error and root mean square error 
49. Graphs showing simulated and measured total nitrogen concentrations for three epilimnetic model segments and a hypolimnetic model segment for Lake Carlos, March 14, 2011, to September 28, 2011, with quantities of absolute mean error and root mean square error.

50. Graphs showing simulated and measured total phosphorus concentrations for three epilimnetic model segments and a hypolimnetic model segment for Lake Carlos, March 14, 2011, to September 28, 2011, with quantities of absolute mean error and root mean square error

51. Graphs showing simulated and measured water temperature for the epilimnion and hypolimnion at the south basin hole in Elk Lake, July 13, 2010, to November 9,2010 , with quantities of absolute mean error and root mean square error

52. Graphs showing simulated and measured water temperature at the south basin hole in Elk Lake for 12 dates in 2010, with quantities of absolute mean error and root mean square error

53. Graphs showing simulated and measured dissolved oxygen concentration at the south basin hole in Elk Lake for 10 dates in 2010, with quantities of absolute mean error and root mean square error.

54. Graphs showing simulated and measured chlorophyll a concentrations for two depths at the south basin hole in Elk Lake, July 13, 2010, to November 9, 2010, with quantities of absolute mean error and root mean square error

55. Graphs showing simulated and measured total nitrogen concentrations for two depths at the south basin hole in Elk Lake, July 13, 2010, to November 9, 2010, with quantities of absolute mean error and root mean square error

56. Graphs showing simulated and measured total phosphorus concentrations for two depths at the south basin hole in Elk Lake, July 13, 2010, to November 9 , 2010 , with quantities of absolute mean error and root mean square error

57. Graphs showing simulated and measured water temperature at the north basin hole in Trout Lake for six dates in 2011, with quantities of absolute mean error and root mean square error.

58. Graphs showing simulated and measured dissolved oxygen concentration at the north basin hole in Trout Lake for nine dates in 2011, with quantities of absolute mean error and root mean square error.

59. Graphs showing smulated and measured total nitrogen concentrations for two depths at the north basin hole in Trout Lake, May 19, 2011, to July 20, 2011, and September 8, 2011, to November 9, 2011

60. Graphs showing simulated and measured total phosphorus concentrations for two depths at the north basin hole in Trout Lake, May 19, 2011, to July 20, 2011, and September 8, 2011, to November 9, 2011 


\section{Tables}

1. Combined locations of continuous and discrete water-quality measurements used for the development of model input or calibration of water temperature, dissolved oxygen, and water-quality constituents for the three separate lake studies

2. Water-quality methods for constituents analyzed in water samples from Lake Carlos, Elk Lake, and Trout Lake, 2010-11

3. Initial constituent concentrations of calibration and validation runs for the Lake Carlos, Elk Lake, and Trout Lake models...

4. Parameters used in the water-quality algorithms for Lake Carlos, Elk Lake, and Trout Lake.

5. Absolute mean error and root mean square error summaries of calibration runs for the three separate lake studies...

6. Absolute mean error and root mean square error summaries of validation runs for the three separate lake studies.

7. Sensitivity analysis for the three separate lake models, in percent change from the calibration run

\section{Conversion Factors}

\begin{tabular}{|c|c|c|}
\hline Multiply & By & To obtain \\
\hline \multicolumn{3}{|c|}{ Length } \\
\hline meter $(\mathrm{m})$ & 3.281 & foot (ft) \\
\hline meter $(\mathrm{m})$ & 39.37 & inches (in.) \\
\hline \multicolumn{3}{|c|}{ Area } \\
\hline square meter $\left(\mathrm{m}^{2}\right)$ & 10.76 & square foot $\left(\mathrm{ft}^{2}\right)$ \\
\hline square kilometer $\left(\mathrm{km}^{2}\right)$ & 0.3861 & square mile $\left(\mathrm{mi}^{2}\right)$ \\
\hline \multicolumn{3}{|c|}{ Volume } \\
\hline cubic meter $\left(\mathrm{m}^{3}\right)$ & 35.31 & cubic foot $\left(\mathrm{ft}^{3}\right)$ \\
\hline \multicolumn{3}{|c|}{ Flow rate } \\
\hline meter per year (m/yr) & 3.281 & foot per year (ft/yr) \\
\hline
\end{tabular}

Temperature in degrees Celsius $\left({ }^{\circ} \mathrm{C}\right)$ may be converted to degrees Fahrenheit $\left({ }^{\circ} \mathrm{F}\right)$ as follows:

${ }^{\circ} \mathrm{F}=\left(1.8 \mathrm{x}^{\circ} \mathrm{C}\right)+32$

Vertical coordinate information is referenced to the National Geodetic Vertical Datum of 1929 (NGVD 29) for Lake Carlos and Elk Lake; vertical coordinate information is referenced to the North American Vertical Datum of 1988 (NAVD 88) for Trout Lake.

Horizontal coordinate information is referenced to the North American Datum of 1983 (NAD 83).

Elevation, as used in this report, refers to distance above the vertical datum.

Specific conductance is given in microsiemens per centimeter at 25 degrees Celsius $(\mu \mathrm{S} / \mathrm{cm}$ at $\left.25^{\circ} \mathrm{C}\right)$.

Concentrations of chemical constituents in water are given either in milligrams per liter (mg/L) or micrograms per liter $(\mu \mathrm{g} / \mathrm{L})$. 


\section{Abbreviations}

$<\quad$ less than

AME absolute mean error

DEM digital elevation model

DHEL Department of Health Environmental Laboratory

DNR Department of Natural Resources

DO dissolved oxygen

GIS geographic information system

Minn. Minnesota

MPCA Minnesota Pollution Control Agency

RMSE root mean square error

SLICE Sustaining Lakes in a Changing Environment

SOD sediment oxygen demand

USACE U.S. Army Corps of Engineers

USGS U.S. Geological Survey 



\title{
Water Quality and Algal Community Dynamics of Three Sentinel Deepwater Lakes in Minnesota Utilizing CE-QUAL-W2 Models
}

\author{
By Erik A. Smith, Richard L. Kiesling, Joel M. Galloway, and Jeffrey R. Ziegeweid
}

\section{Abstract}

Water quality, habitat, and fish in Minnesota lakes will potentially be facing substantial levels of stress in the coming decades primarily because of two stressors: (1) land-use change (urban and agricultural) and (2) climate change. Several regional and statewide lake modeling studies have identified the potential linkages between land-use and climate change on reductions in the volume of suitable lake habitat for coldwater fish populations. In recent years, water-resource scientists have been making the case for focused assessments and monitoring of sentinel systems to address how these stress agents change lakes over the long term. Currently in Minnesota, a large-scale effort called "Sustaining Lakes in a Changing Environment" is underway that includes a focus on monitoring basic watershed, water quality, habitat, and fish indicators of 24 Minnesota sentinel lakes across a gradient of ecoregions, depths, and nutrient levels. As part of this effort, the U.S. Geological Survey, in cooperation with the Minnesota Department of Natural Resources, developed predictive waterquality models to assess water quality and habitat dynamics of three select deepwater lakes in Minnesota. The three lakes (Lake Carlos in Douglas County, Elk Lake in Clearwater County, and Trout Lake in Cook County) were assessed under recent (2010-11) meteorological conditions. The three selected lakes contain deep, coldwater habitats that remain viable during the summer months for coldwater fish species.

Hydrodynamics and water-quality characteristics for each of the three lakes were simulated using the CE-QUAL-W2 model, which is a carbon-based, laterally averaged, twodimensional water-quality model. The CE-QUAL-W2 models address the interaction between nutrient cycling, primary production, and trophic dynamics to predict responses in the distribution of temperature and oxygen in lakes.

The Lake Carlos model was calibrated using data collected from April through November 2010 including vertical profiles of water temperature and dissolved oxygen concentration at a deep location in the northern part of Lake Carlos, and water-quality constituent concentrations collected in the epilimnion and hypolimnion at the same site. The calibrated model was validated with data collected from March through September 2011. The Elk Lake model was calibrated using data collected from April through November 2011 including vertical profiles of water temperature and dissolved oxygen concentration at a deep location in the southern part of Elk Lake, and water-quality constituent concentrations collected in the epilimnion and hypolimnion at the same site. The calibrated model was validated with data collected from July through November 2010. The Trout Lake model was calibrated using data collected from April through October 2010 including vertical profiles of water temperature and dissolved oxygen concentration at a deep location in the northeastern part of Trout Lake, and water-quality constituent concentrations collected in the epilimnion and hypolimnion at the same site. The calibrated Trout Lake model was validated with data collected during two separate periods from May through November 2011.

The CE-QUAL-W2 models for all three lakes successfully predicted water temperature, on the basis of the two metrics of absolute mean error and root mean square error, using measured inputs of water temperature and nutrients. One of the main calibration tools for CE-QUAL-W2 model development was the vertical profile temperature data, available for all three lakes. For all three lakes, the absolute mean error and root mean square error were less than 1.0 degree Celsius and 1.2 degrees Celsius, respectively, for the different depth ranges used for vertical profile comparisons. In Lake Carlos, simulated water temperatures compared better to measured water temperatures in the epilimnion than in the hypolimnion. The reverse was true for the other two lakes, Elk Lake and Trout Lake, where the simulated results were slightly better for the hypolimnion than the epilimnion. The model also was used to approximate the location of the thermocline throughout the simulation periods, approximately April to November, in all three lake models. Deviations between the simulated and measured water temperatures in the vertical lake profile commonly were because of an offset in the timing of thermocline shifts rather than the simulated results missing thermocline shifts altogether.

In addition to water temperature, the CE-QUAL-W2 models for all three lakes successfully predicted dissolved 
oxygen concentration based on the two metrics of absolute mean error and root mean square error. Simulated dissolved oxygen concentration generally tracked the measured dissolved oxygen concentration for the calibration and validation periods. Simulated vertical profiles of dissolved oxygen concentration generally matched the largest change in measured dissolved oxygen concentration, including the approximate depth, slope, and timing of large shifts.

The model also captured the trajectories of water temperature and dissolved oxygen concentration over time at multiple depths. This indicates that the model was accurately simulating the underlying metabolic processes in each lake. For Lake Carlos, the simulated dissolved oxygen concentration in the metalimnion tracked the dissolved oxygen concentration minimum by accurately simulating the oxygen demand associated with decomposition of algal carbon below the photic zone. In Elk Lake, the simulated metalimnetic chlorophyll maximum matched the measured metalimnetic oxygen maximum. In both cases, simulated in-lake processes of primary production, algal mortality, and carbon and nutrient recycling matched the measured dissolved oxygen dynamics. Both cases illustrate that the internal trophic dynamics in these deep, coldwater lakes are important factors controlling much of the observed biogeochemistry.

Adjustments to the water balance were made through changes to the gains and losses in the distributed tributary flow, which lumps all ungaged inflow and groundwater interactions together in one value. Within the CE-QUAL-W2 model, the distributed tributary flow could be positive or negative, and several iterations were completed before the water balance of the model was re-established. A water balance was considered complete when the absolute mean error and root mean square error quantities were less than 0.01 meter for the simulated water-surface elevation.

Boundary factors, such as topography and shoreline tree cover, can have a profound effect on wind mixing. Wind effects from these boundary factors were indirectly augmented through the wind sheltering coefficient. The assigned wind sheltering coefficient was found to be a sensitive parameter, which affected the amount of mixing that occurred in the vertical dimension and thereby the depth of the thermocline over time.

Algal dynamics were captured by three general groups: (1) diatoms, (2) green algae, and (3) blue-green algae. Simulated algal-growth temperature coefficients were consistent across all three lakes, in addition to the algal-growth rates and the light saturation intensity at the maximum photosynthetic rate. Ammonia, nitrate plus nitrite, and orthophosphorus concentrations in all three lakes were largely affected by the inflows and the lake hydrodynamics; in general, the simulated concentrations compared well to the measured data. Simulated total nitrogen and total phosphorus concentrations did not compare as well to measured data, particularly in the hypolimnion.

\section{Introduction}

Water quality, habitat, and fish in Minnesota lakes are facing substantial risks from land-use change and climate change. In recent years, water-resource scientists have been making the case for focused assessments and monitoring of "sentinel" systems (Jassby, 1998; Carpenter and others, 2007; Magner and Brooks, 2008, Williamson and others, 2008) to assess how these stressors affect lakes over the long term. Lakes and their contributing drainage basins are highly complex, and development of a mechanistic understanding of the linkage between basin-based stressors and lake metabolism is best accomplished by taking a long-term, adaptive approach towards water-resource management (Magnuson and others, 1990). Intensive, detailed study of representative systems is critical to understanding cause and effect mechanisms, but an equally important need is to compare this detailed information to a broader set of similar systems. For the Minnesota Department of Natural Resources (DNR) Sustaining Lakes in a Changing Environment (SLICE) research program, these study design requirements are being met by coupling intensive, predictive modeling of three "super sentinel" lakes with 24 Minnesota sentinel lakes distributed in a split-panel design of environmental monitoring that includes basic watershed, water quality, habitat, and fish indicators cross a gradient of ecoregions, depths, and nutrient levels (McDonald, 2003). The structure of the SLICE program also includes a long-term ecological monitoring component.

The ability to simulate the effects of large-scale stressors (for example, watershed land-use alterations or decade-level climate changes) on lake ecosystems is a critical component of a proactive management plan for Minnesota lakes. Several regional and statewide lake modeling studies have illustrated the potential linkages between climate change, lake morphology, and reductions in fish habitat in the form of temperature and dissolved oxygen (DO) distributions for Minnesota and the north-central United States (for example, see summaries in Stefan and Fang, 1994; Stefan and others, 1995, 1996; De Stasio and others, 1996; Fang and Stefan, 1999; Fang and others, 2004a, 2004b; Jacobson and others, 2008). These models have documented the relative importance of lake-basin geometry, ice-free season, thermal stratification, DO stratification, and wind-driven mixing to the development of sustainable fish habitat in deepwater lakes of the region; however, the potential trophic-dynamic response to simultaneous changes in land use and climate is less well understood, as is the response of specific lakes to these historical and hypothetical changes. Questions also remain as to how the complex food webs that support fish guilds within these modeled systems will respond to the predicted physical changes in fish habitat (De Stasio and others, 1996).

The U.S. Geological Survey (USGS), in cooperation with the Minnesota DNR, developed predictive water-quality models to assess water quality and habitat dynamics of three selected deepwater lakes in Minnesota (fig. 1; table 1) under recent (2010-11) meteorological conditions. The three 


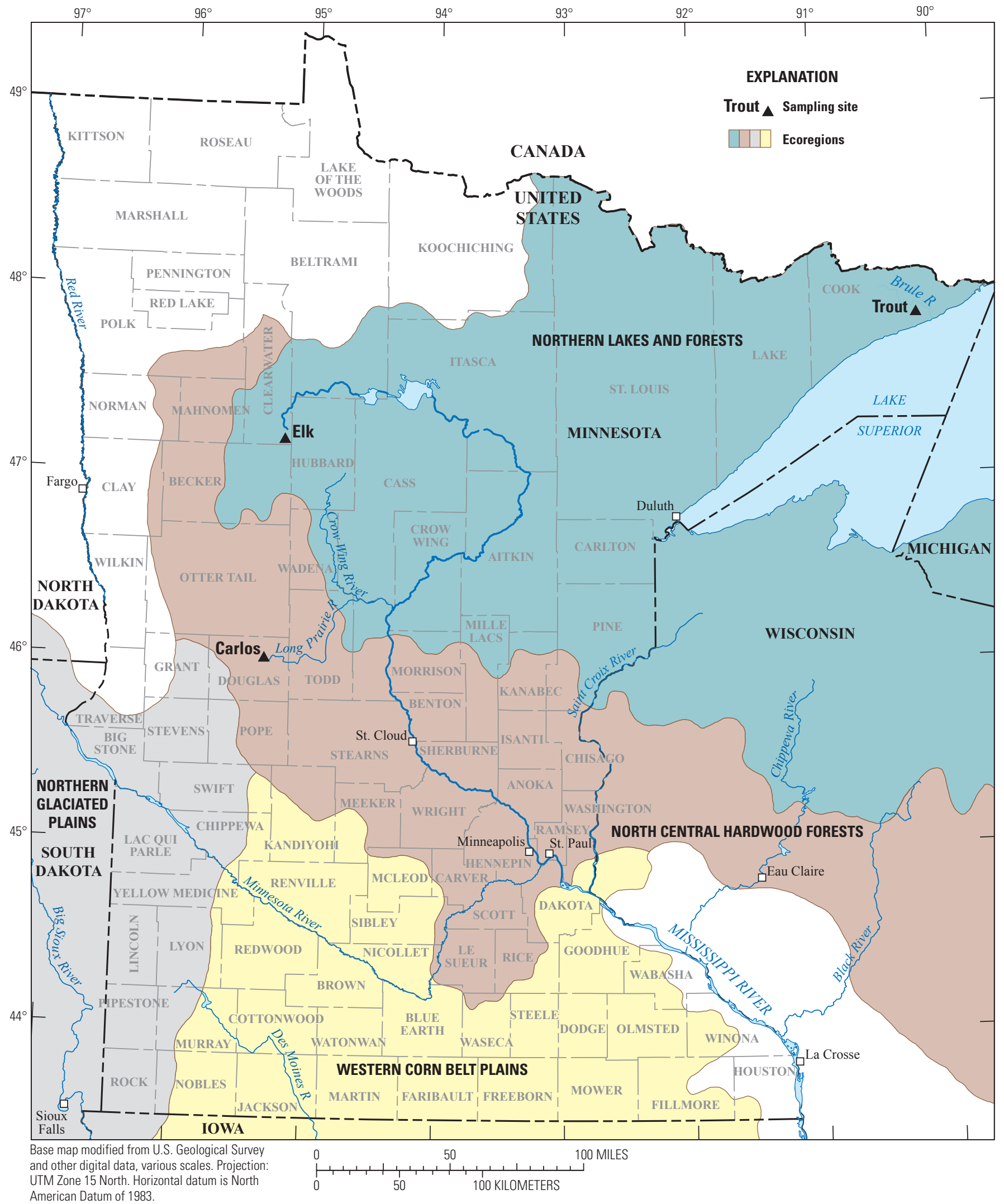

Figure 1. Major ecoregions and the three lakes for this study. 


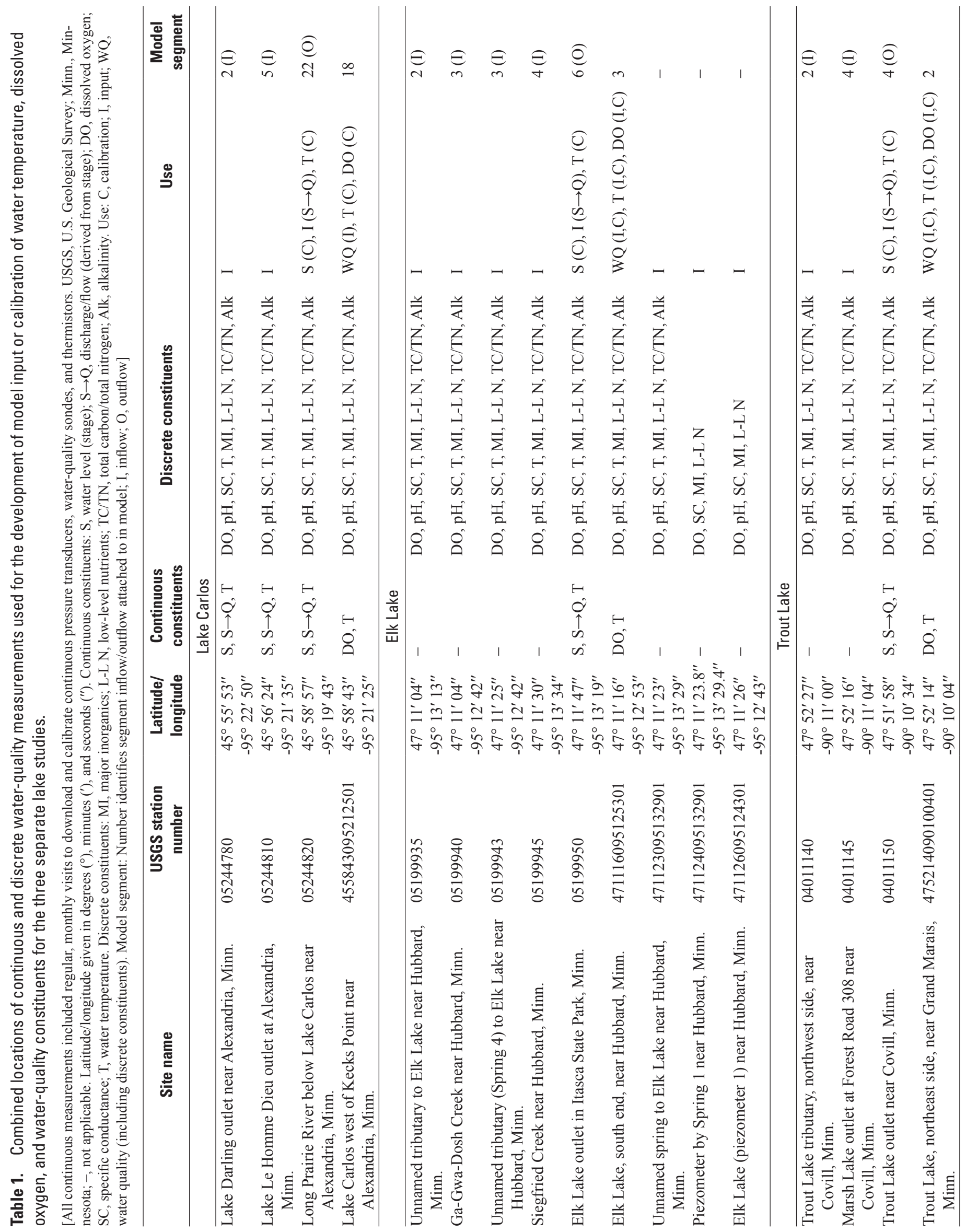


selected lakes—Lake Carlos, Elk Lake, and Trout Lake - contain deep, coldwater habitats that remain viable during the summer months for coldwater fish species. The chosen modeling framework for this study, CE-QUAL-W2 (Cole and Wells, 2008), is a two-dimensional, laterally averaged, hydrodynamic and water-quality model originally developed by the U.S. Army Corps of Engineers (USACE) and currently supported by Portland State University (2013). The CE-QUAL-W2 model addresses the interaction between nutrient cycling, primary production, and trophic dynamics to predict responses in the distribution of temperature and oxygen in lakes, a primary goal of this study.

\section{Purpose and Scope}

The purpose of this report is to outline the development, calibration, and validation of a mechanistic, biophysical waterquality model for each of three deepwater lakes in Minnesota. All three lakes are classified as supporting deep, coldwater fisheries habitat. Lake Carlos was calibrated using data collected from April 2010 through November 2010, and validated with data from 2011. Elk Lake was calibrated using data collected from May 2011 through November 2011, and validated with data from 2010. Trout Lake was calibrated using data collected from April 2010 through October 2010, and validated with data from 2011. A sensitivity analysis was also conducted to better understand the model's response to some of its most important parameters or inputs.

\section{Study Areas}

Three deepwater lakes in Minnesota that are classified as super sentinel lakes (Minnesota Department of Natural Resources, 2010) are the focus of this study: Lake Carlos in Douglas County, Elk Lake in Clearwater County, and Trout Lake in Cook County. Previous extensive characterization of all three lakes and their watersheds was conducted during the initial phase of SLICE (Minnesota Pollution Control Agency, 2009b, 2009c, 2009d), summarized into separate reports for each lake. All three lakes are considered deep, coldwater lakes that harbor substantial coldwater fish populations.

\section{Lake Carlos}

Lake Carlos (fig. 2) in Douglas County, Minn., is the terminal lake in the Alexandria Chain of Lakes, located in the North Central Hardwood Forests ecoregion. The Alexandria Chain of Lakes were carved out during the last glaciation, and the area surrounding Lake Carlos is made up of thick deposits of glacial outwash and till from the Des Moines lobe. The underlying bedrock is Precambrian granites and slates (Minnesota Pollution Control Agency, 2009a), although little is known about the Precambrian formations in the area. Lake Carlos is considered a dimictic lake, generally starting off well-mixed before summer, with a distinctive thermocline that develops in the summer months and mixing again in the late fall (Minnesota Pollution Control Agency, 2009b). The water balance of the watershed is typically controlled by a spring snowmelt in late March or early April, followed by periodic large rain events in the summer. Precipitation in the region averages from 0.61 to 0.71 meters per year (m/yr; 24 to $28 \mathrm{inches}$ per year [in/yr]), with typical evaporation rates of $0.94 \mathrm{~m} / \mathrm{yr}$ for regional lakes (Minnesota Pollution Control Agency, 2009a). Climate in the region has been known to experience sustained drought periods, which can have a profound effect on lake level. The lowest lake level ever documented on Lake Carlos was 412.01 meters (m) above the National Geodetic Vertical Datum of 1929 in 1937 (U.S. Geological Survey, 2013a), which was $1.45 \mathrm{~m}$ below the lowest level recorded in 2010 and 2011.

Primary inflow to Lake Carlos occurs in the southern part of the lake through two distinct channels out of Lakes Darling and Le Homme Dieu, both of which were primary sampling locations during this study for nutrient and major inorganic constituents, continuous water temperature, and discharge. The Lake Darling outlet near Alexandria, Minn. (USGS station number 05244780; hereafter referred to as Lake Darling outlet) is located within the channel between Lake Carlos and Lake Darling along the southeastern margin of Lake Carlos and is considered the primary inflow for purposes of the CEQUAL-W2 modeling. The Lake Le Homme Dieu outlet at Alexandria, Minn. (USGS station number 05244810; hereafter referred to as Lake Le Homme Dieu outlet) was located within the channel between Lake Le Homme Dieu and Lake Carlos along the southern margin of Lake Carlos. The headwater of the Long Prairie River (USGS station number 05244820; hereafter referred to as Long Prairie River) is the principal outflow channel for the lake.

The lake has an area of 10.2 square kilometers $\left(\mathrm{km}^{2}\right)$ and a volume of 150.6 million cubic meters $\left(\mathrm{m}^{3}\right)$, with a maximum depth of $50 \mathrm{~m}$ (Minnesota Pollution Control Agency, 2009a). The Lake Carlos drainage basin is $634 \mathrm{~km}^{2}$, for a ratio of basin to lake area of $62: 1$. The lake has two areally extensive deep areas. The deep area in the northern part of the lake was sampled at Lake Carlos west of Kecks Point near Alexandria, Minn. (USGS station number 455843095212501; hereafter referred to as Kecks Point), which had a depth of $43 \mathrm{~m}$. This location was used for extensive in-lake water-quality sampling, periodic vertical profiles of water temperature and DO, and continuous monitoring of water temperature at various depths.

\section{Elk Lake}

Elk Lake (fig. 3) in Clearwater County, Minn., is a headwater lake of the Mississippi River. Currently (2013) part of the North Central Hardwood Forests ecoregion, Elk Lake sits on the sensitive boundary between prairie and forest ecoregions and has switched between the two ecoregions since the post-glacial period up to the present (Wright, 1993). The Elk Lake region is highlighted by the Itasca moraine, a 


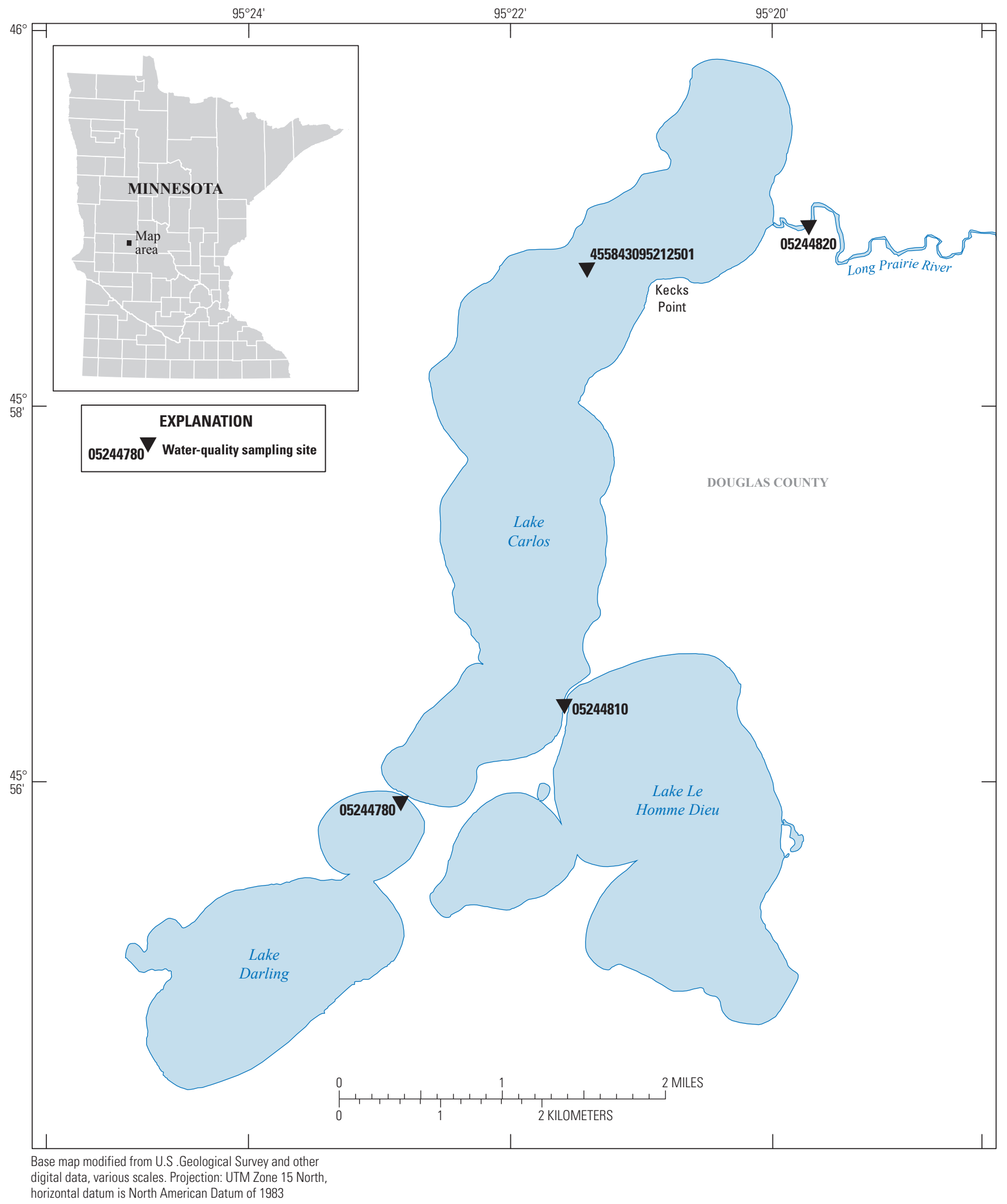

Figure 2. Location of water-quality sampling sites of Lake Carlos, Minnesota. 


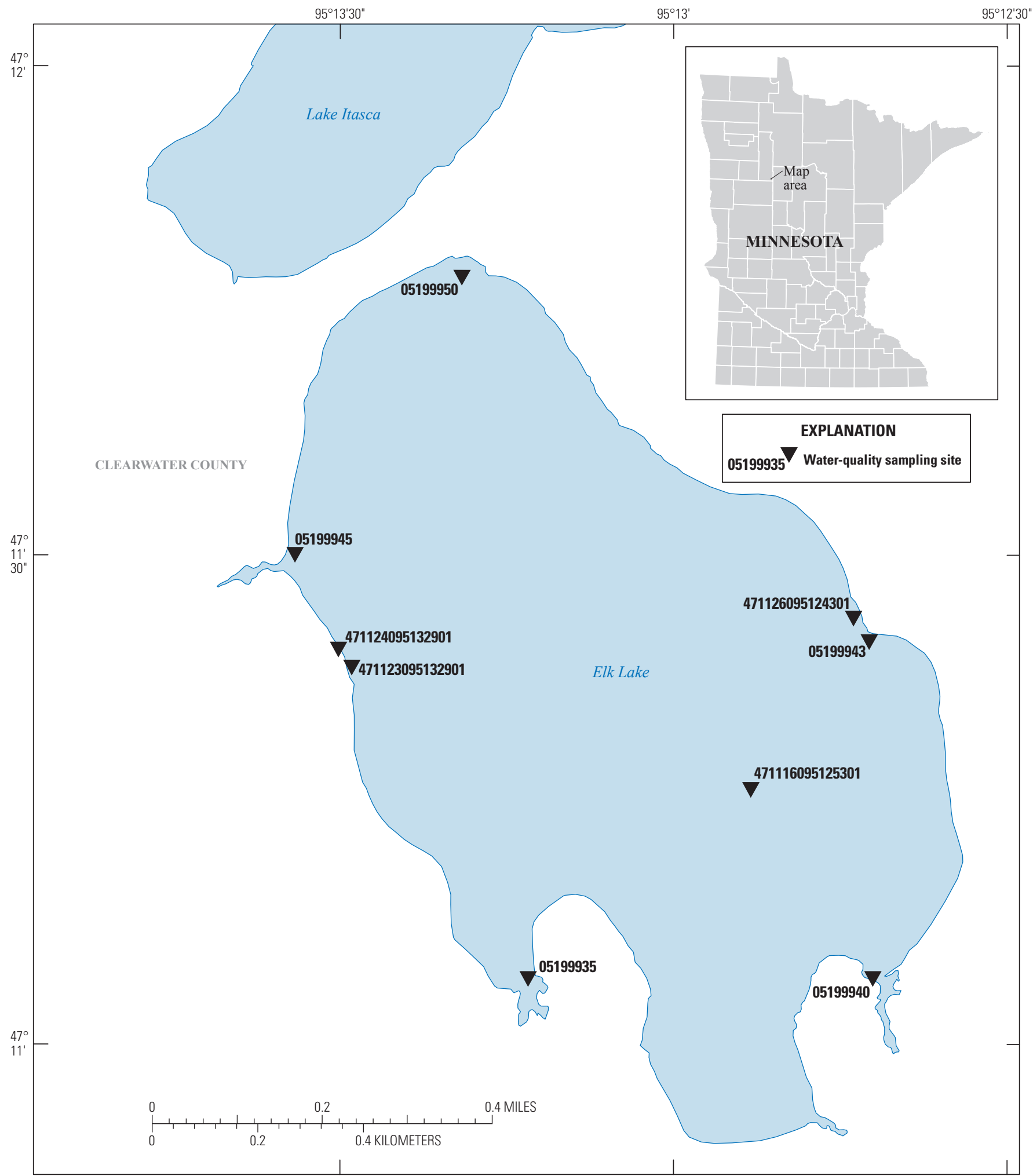

Base map modified from U.S. Geological Survey and other digital data, various scales. Projection: UTM Zone 15 North, horizontal datum is North American Datum of 1983

Figure 3. Location of water-quality sampling sites of Elk Lake, Minnesota. 
heterogeneous and thick deposit made up of till and outwash. Local topography of the area contains hills, made up of accumulated sediment from melting glacial ice, and depressions that contain lakes and wetlands, with Elk Lake and its surrounding wetlands as an example (Wright, 1993). The regional glacial geology contains a complex web of moraines, which are characterized by Wright (1993). Elk Lake is considered a dimictic lake, remaining stratified for most of the monitoring season (Minnesota Pollution Control Agency, 2009c).

The water balance of the Elk Lake drainage basin typically is controlled by a spring snowmelt in late March or early April, followed by periodic large rain events in the summer. Precipitation in the region averages approximately $0.71 \mathrm{~m} / \mathrm{yr}$ (28 in/yr), with evaporation rates likely similar to Lake Carlos. Elk Lake area precipitation was considered above average in 2010, receiving $0.15-0.25 \mathrm{~m}$ (6-10 inches) above a typical average year (Minnesota Pollution Control Agency, 2011a). Also similar to Lake Carlos, climate in the region has been known to experience sustained drought periods, given the complex climatic gradient of being at the junction of Arctic, Pacific, and Gulf of Mexico air masses.

Unlike Lake Carlos, inflow is characterized by diffuse flow through a series of bordering wetlands and small channels around the perimeter of Elk Lake. For purposes of this study, primary inflow through the lake came through four ungaged tributaries: unnamed tributary to Elk Lake near Hubbard, Minn. (USGS station number 05199935; hereafter referred to as site UTEL1), Ga-Gwa-Dosh Creek near Hubbard, Minn. (USGS station number 05199940; hereafter referred to as Ga-Gwa-Dosh Creek), unnamed tributary (Spring 4) to Elk Lake near Hubbard, Minn. (USGS station number 05199943; hereafter referred to as site UTEL2), and Siegfried Creek near Hubbard, Minn. (USGS station number 05199945; hereafter referred to as Siegfried Creek). Nutrient and major inorganic sampling was less frequent for these sites than for the two inflow channels into Lake Carlos. Additionally, two groundwater fed springs and a piezometer were sampled to characterize the groundwater seepage through the lakebed, likely a substantial part of the overall lake water balance. The Elk Lake outlet in Itasca State Park, Minn. (USGS station number 05199950; hereafter referred to as Elk Lake outlet) is located at the northern end of the lake; the outlet is a small channel that connects Elk Lake to Lake Itasca and is the principal outflow channel for the lake.

The lake has an area of $1.1 \mathrm{~km}^{2}$ and a volume of 12.3 million $\mathrm{m}^{3}$, with a maximum depth of $28.3 \mathrm{~m}$ (Minnesota Pollution Control Agency, 2011a). The Elk Lake drainage basin is $8.0 \mathrm{~km}^{2}$, for a ratio of basin to lake area of 7.4:1. The lake has a deep spot with a maximum depth of $28 \mathrm{~m}$ located in the southern part of the lake, Elk Lake, south end, near Hubbard, Minn. (USGS station number 471116095125301; hereafter referred to as the south basin hole), that was used for extensive in-lake water-quality sampling, periodic vertical profiles of water temperature and DO, and continuous monitoring of water temperature at various depths.
Extensive research, as described later in the "Previous Studies" section, has been conducted on Elk Lake because of its continuous varve record of climate change over the past 10,000 years. With its relatively small ratio of basin to lake area, location along the forest and prairie ecotone boundary (Dean, 1993), and relatively small volume of coldwater fish habitat, Elk Lake is considered particularly vulnerable to future increases in water temperature because of climate change.

\section{Trout Lake}

Trout Lake (fig. 4) in Cook County, Minn., is located within the Lake Superior Basin, approximately $16 \mathrm{~km}$ northeast of Grand Marais, Minn. Trout Lake is part of the Northern Lakes and Forests ecoregion, sometimes further differentiated as a Canadian Shield lake (Minnesota Pollution Control Agency, 2011b). Located in a bedrock basin, the contributing drainage basin has only a thin veneer of unconsolidated materials over bedrock, making the local geological history quite different from Lake Carlos and Elk Lake (Minnesota Pollution Control Agency, 2011b). Trout Lake is also considered a dimictic lake, typically becoming stratified from May until October (Minnesota Pollution Control Agency, 2009d). Similar to Lake Carlos and Elk Lake, the water balance of the basin is typically controlled by a spring snowmelt followed by periodic large rain events in the summer. Precipitation in the region averages approximately $0.85 \mathrm{~m} / \mathrm{yr}$ (33.6 in/yr), higher than either of the other two lakes. Climate in the region largely is controlled by its proximate location to Lake Superior, which generally makes for cooler summers and warmer winters than in other parts of Minnesota (Minnesota Department of Natural Resources, 2013a).

Flow into Trout Lake is intermittent, making continuous discharge measurements difficult; therefore, periodic discharge measurements were completed at two small channels along the western margin of Trout Lake: (1) Trout Lake tributary, northwest side, near Covill, Minn. (USGS station number 04011140; hereafter referred to as Trout Lake tributary) and (2) Marsh Lake outlet at Forest Road 308 near Covill, Minn. (USGS station number 04011145; hereafter referred to as Marsh Lake outlet). Nutrient and major inorganic sampling was similar in frequency to the Elk Lake inflow sites. The Trout Lake outlet near Covill, Minn. (USGS station number 04011150; hereafter referred to as Trout Lake outlet) is located at the southern end of the lake and is the principal outflow channel for the lake.

The lake has an area of $1.0 \mathrm{~km}^{2}$ and a volume of 10.6 million $\mathrm{m}^{3}$, with a maximum depth of $23.5 \mathrm{~m}$ (Minnesota Pollution Control Agency, 2011b). The Trout Lake drainage basin is $3.6 \mathrm{~km}^{2}$, with a ratio of basin to lake area of 3.6:1. The lake has areally extensive deep areas in both the northern and southern basins of the lake. The site of Trout Lake, northeast side, near Grand Marais, Minn. (USGS station number 475214090100401; hereafter referred to as the north basin hole), with a depth of $21 \mathrm{~m}$, was located in the north basin. 


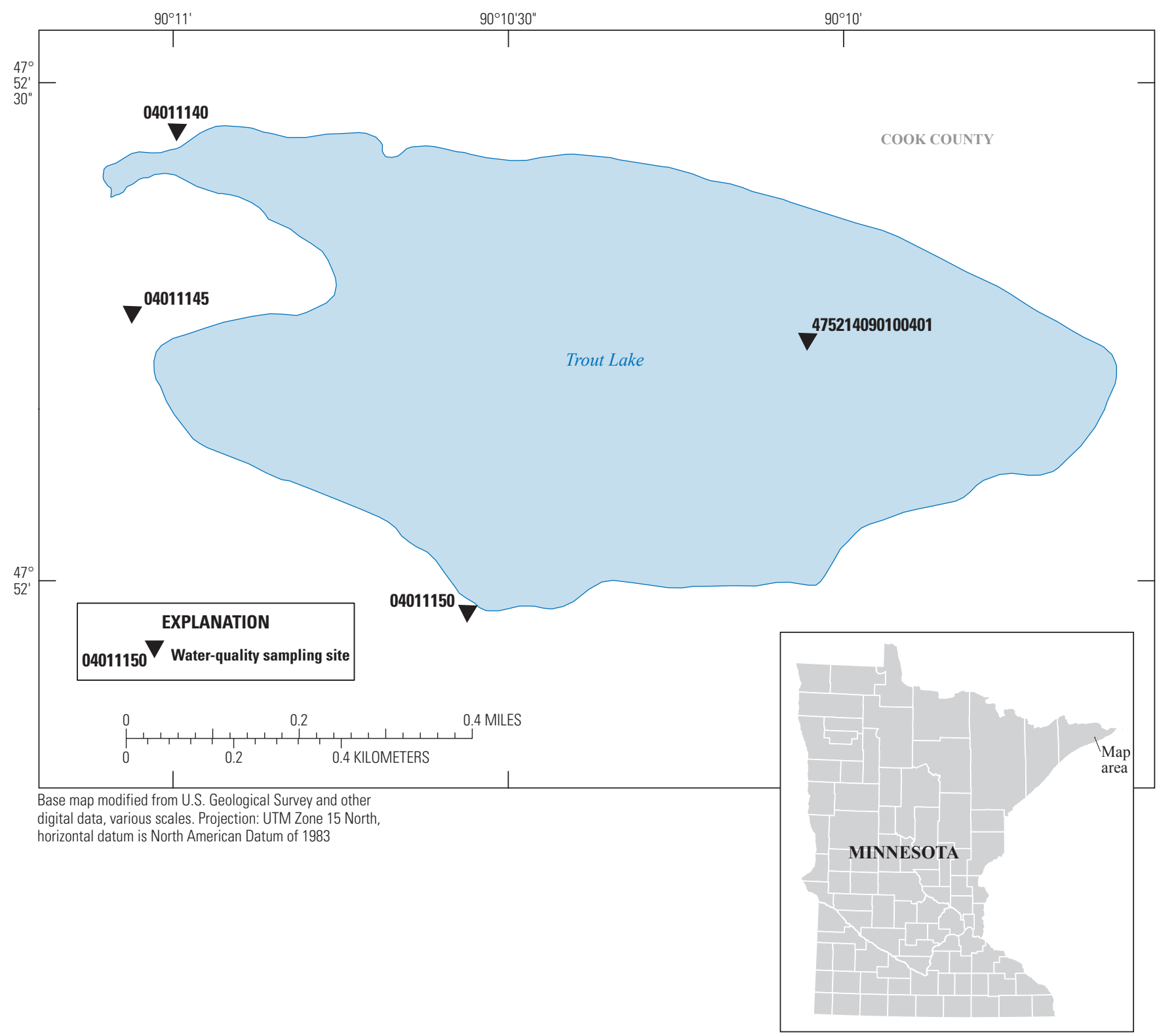

Figure 4. Location of water-quality sampling sites of Trout Lake, Minnesota.

This location was used for extensive in-lake water-quality sampling, periodic vertical profiles of water temperature and DO, and continuous monitoring of water temperature at various depths.

With its small ratio of basin to lake area, Trout Lake is considered vulnerable to substantial changes in the surrounding forest, given that the forest acts as a buffer on wind-driven mixing. A loss of part or all of the surrounding forest could induce more wind-driven mixing in the summer, which could result in loss of habitat refuge for coldwater fish populations.

\section{Previous Studies}

Jacobson and others (2008) included Lake Carlos as one of 17 lakes that experienced a cisco mortality event in 2006 in order to quantify an adult lake cisco oxythermal lethal niche boundary for their study. Mortality events of lake ciscoes (Coregonus artedi), a coldwater stenotherm, are a potential indicator of environmental stressors, such as land-use change and climate change, because of a disturbance in a lake's thermal regime. Elk Lake has been the subject of extensive paleoclimatic research, particularly because of its location near 
the forest-prairie ecotone boundary (Dean, 1993). In addition to characterizing postglacial varve chronology (Anderson and others, 1993), studies have been completed characterizing the geochemistry of surficial sediments (Dean, 1993), modern sedimentation (Nuhfer and others, 1993), Holocene diatom succession (Bradbury and Dieterich-Rurup, 1993), and the vegetation history of Elk Lake (Whitlock and others, 1993). All three lakes (Lake Carlos, Elk Lake, and Trout Lake) were included in the potential future climate scenarios of cisco refuge lakes to assess potential cisco refugia, using the MINLAKE 2010 water-quality model (Fang and others, 2012).

\section{Methods for Model Development}

All three models for the lakes (Carlos, Elk, and Trout) were constructed using CE-QUAL-W2, version 3.60 (V3.6) (Cole and Wells, 2008), which is a two-dimensional, laterally averaged, hydrodynamic and water-quality model originally developed by the U.S. Army Corps of Engineers (USACE) and currently supported by Portland State University (2013). Because the model is laterally averaged, it is best suited for water bodies with a fairly homogenous cross section. The CEQUAL-W2 V3.6 model calculates the hydrodynamic properties of water-surface elevation, velocities, and temperature and can simulate 28 water-quality state variables in addition to temperature. An advantage of CE-QUAL-W2 over other hydrodynamic and water-quality models is that the hydrodynamic and water-quality modules are coupled together through an equation of state for density, which is dependent on temperature, suspended solids, and dissolved solids. This enables the water-quality model to feed back into the hydrodynamic part of the model. Although the lateral averaging of CE-QUAL-W2 is better suited for long, narrow water bodies, such as reservoirs, rivers, and estuaries, CE-QUAL-W2 has been successfully applied in lake settings (Sullivan and Rounds, 2004; Sullivan and others, 2007). Lake Carlos has a relatively long and narrow body appropriate for CE-QUAL-W2. Although Elk Lake and Trout Lake did not meet the same criterion of a long and narrow body, both of these lakes exhibited enough homogeneity in water-quality and water-temperature data such that laterally averaging did not compromise the integrity of the model. Vertical variations captured with CE-QUAL-W2 are important for distinguishing temporal variations in the lake epilimnion and hypolimnion. Initial calibration included a water balance based on water-surface elevation and water temperature at various stations for each lake. Additional calibration targets included water temperature and DO depth profiles, in addition to discrete measurements of ammonia, nitrate plus nitrite, total nitrogen, total phosphorus, orthophosphorus, and chlorophyll $a$.

The individual lake models were developed in several phases. First, data were collected to determine the hydrological, thermal, and water-quality boundary conditions for the calibration year. A summary of the discrete and continuous constituents collected for all three lakes, further split by sampling locations, is shown in table 1. Selection of the calibration year for each lake was based on the most extensive datasets available, specifically for outflow discharge, water-surface elevation, and water temperature data, because these datasets were critical for driving the model hydrodynamics. All other data were aggregated to best define the initial boundary conditions. These data were also used later in the calibration and validation processes. Next, the model grid was constructed based on available lake bathymetry data. Datasets necessary to run CE-QUAL-W2 were formatted to fit the input data structure. Prior to initial water-balance calibration, input parameters were selected, mainly based on default values either prepopulated within CE-QUAL-W2 (Cole and Wells, 2008) or previous USGS CE-QUAL-W2 modeling efforts (Galloway and Green, 2006; Galloway and others, 2008).

\section{Water-Balance Approach}

The following subsections provide details of the waterbalance approach used for each of the lakes. The waterbalance approach for the lakes included an initial calibration, followed by refined calibrations.

\section{Lake Carlos}

The water balance of Lake Carlos was calibrated for the period of April-November 2010 by comparing measured water levels to simulated water levels at Long Prairie River, which is the main surface-water outflow for Lake Carlos (fig. 2; table 1). Two gaged inflow tributaries, the Lake Darling outlet and the Lake Le Homme Dieu outlet (fig. 2; table 1), provided the continuous discharge measurements for the entire calibration period. Adjustments were made to the gains and losses in the distributed tributary flow, which lumps all ungaged inflow and groundwater interactions, until a reasonable water balance was attained. After initial calibration, refined calibration focused on the vertical profiles of DO and temperature at Kecks Point. Additionally, the refined calibration step included the water-quality parameters highlighted previously (ammonia, nitrate plus nitrite, total nitrogen, total phosphorus, orthophosphorus, and chlorophyll $a$ ). Final refinement of model parameters, after several hundred iterations, was achieved with the realization of low absolute mean error (AME) and root mean square error (RMSE) values for most of the target constituents. The AME and RMSE targets were operationally defined by other USGS reports utilizing CEQUAL-W2, such as Pueblo Reservoir, southeastern Colorado (Galloway and others, 2008) and Table Rock Lake, Missouri (Green and others, 2003). Details of calculating the AME and RMSE values are included in the "Model Calibration" section. Most model runs included one adjustment with a subsequent model run to characterize the parameter sensitivity. 


\section{Elk Lake}

The water balance of Elk Lake was initially calibrated for the period of April-November 2011 by comparing measured water levels to simulated water levels at the Elk Lake outlet, which is the main surface-water outflow located at the northern end of the lake. Four ungaged inflow tributaries (UTEL1, Ga-Gwa-Dosh Creek, UTEL2, and Siegfried Creek), located around the margins of Elk Lake (fig. 3; table 1), were fixed as a ratio to the outflow discharge based on the contributing basin area for the inflow compared to the overall basin area. Similar to methods for Lake Carlos, adjustments were made to the gains and losses in the distributed tributary flow until a reasonable water balance as well as low AME and RMSE values for lake level elevation could be achieved. After initial calibration, additional calibration targets included vertical profiles of DO and temperature for specific dates throughout the year and water-quality constituents for the Elk Lake outlet and the south basin hole (fig. 3; table 1). Similar to Lake Carlos, final refinement of model parameters was achieved with the realization of low AME and RMSE values for most of the target constituents.

\section{Trout Lake}

The water balance of Trout Lake was initially calibrated for the period of April-October 2010 by comparing measured water levels to simulated water levels at the Trout Lake outlet, which is the main surface-water outflow located at the southern end of the lake (fig. 4). Two ungaged inflow tributaries (Trout Lake tributary and Marsh Lake outlet), located along the western margin of Trout Lake, were fixed as a ratio to the outflow discharge based on the contributing watershed area for the inflow compared to the overall basin watershed area (fig. 4; table 1). As in both the Lake Carlos and Elk Lake models, adjustments were made to the gains and losses in the distributed tributary flow for the Trout Lake model until a reasonable water balance and low AME and RMSE values could be achieved for lake-level elevations. After initial calibration, additional calibration targets included vertical profiles of DO and temperature for specific dates throughout the year and water-quality data collected at the Trout Lake outlet and the north basin hole. Similar to the Lake Carlos and Trout Lake models, final refinement of model parameters was achieved with the realization of low AME and RMSE values for most of the target constituents.

\section{Bathymetric Data and Computational Grid}

Information from a digital elevation model (DEM) (U.S. Geological Survey, 2013a) and available bathymetric data (Minnesota Geospatial Information Office, 2013a) were used to generate bathymetric cross sections for the CE-QUAL-W2 model. Accurate model reconstruction is important given that this reconstruction is the finite difference representation of the lake itself. This accuracy can be verified by comparisons between the measured bathymetry and model grid for the curves relating water-surface elevation and lake volume and curves relating water-surface elevation and lake-surface area for each of the lakes (figs. 5-7).

A geographic information system (GIS) layer was obtained for the drainage basin for each lake from the Minnesota Lake Watershed Delineation Project (Minnesota Department of Natural Resources, 2013b) or generated from the USGS Minnesota StreamStats application (Ries and others, 2004; Lorenz and others, 2009). The GIS layer for each lake drainage basin was used to define the maximum outer boundary of the bathymetric model grid for each lake. The best available elevation data were used and ranged from 1-m DEMs based on light detection and ranging (LiDAR) (Minnesota Geospatial Information Office, 2013b) to 30-m DEMs from the USGS National Elevation Dataset (U.S. Geological Survey, 2013a). Bathymetric surveys of each of the three lakes were available from the Minnesota DNR as GIS layers (Minnesota Geospatial Information Office, 2013a). The basic process was to combine the land elevation layer with the bathymetric data to produce a gridded, three-dimensional

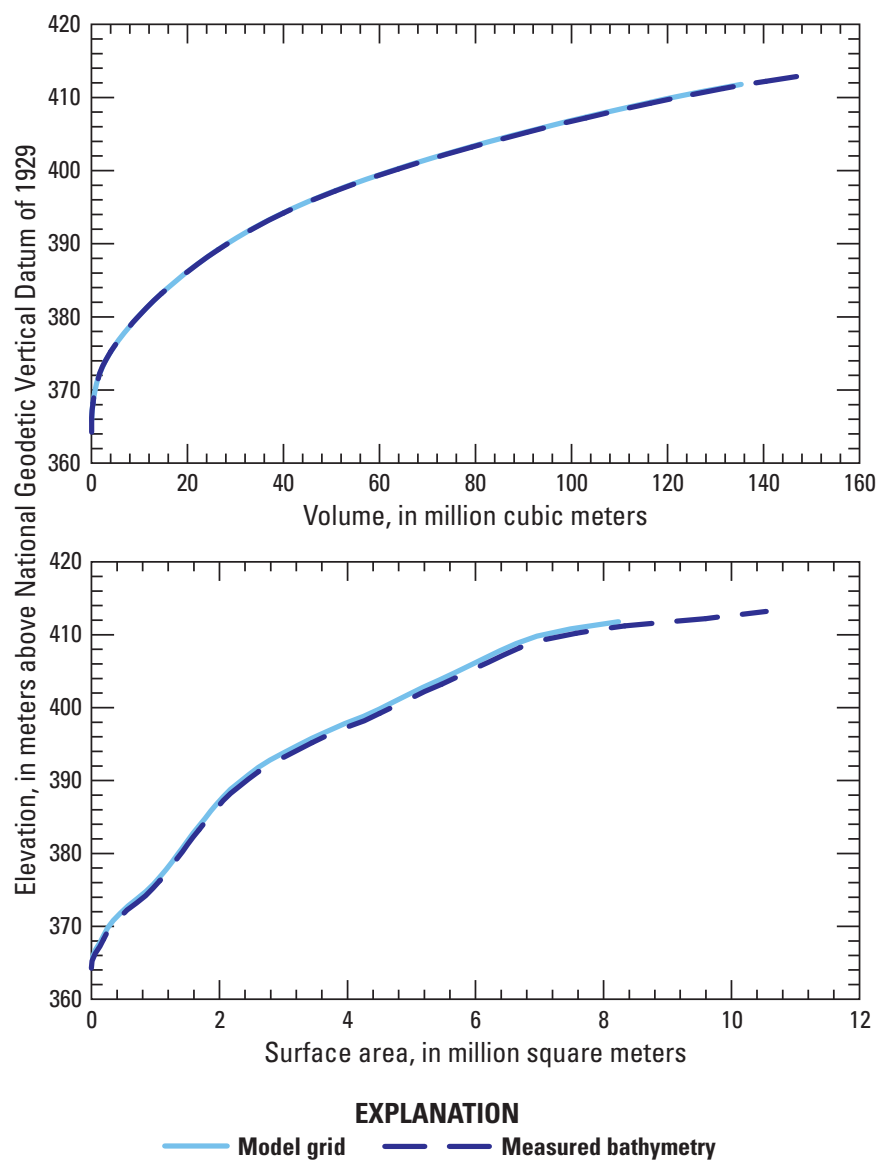

Figure 5. Lake volume and lake-surface area to water-surface elevation for Lake Carlos using the measured bathymetry (Minnesota Geospatial Information Office, 2013a) and as represented by the model grid. 


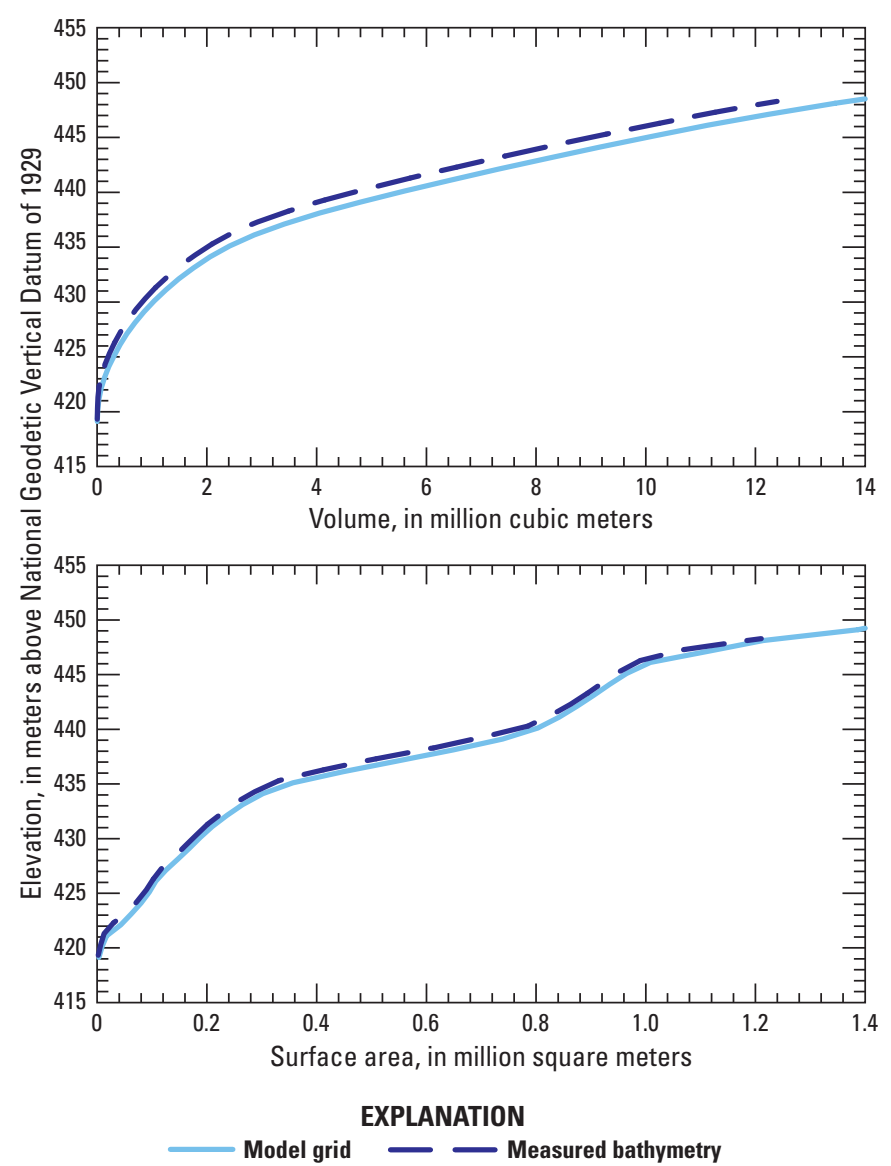

Figure 6. Lake volume and lake-surface area to water-surface elevation for Elk Lake using the measured bathymetry (Minnesota Geospatial Information Office, 2013a) and as represented by the model grid.

model of the surface area and depth of each lake. The next step was to identify the deepest elevation value of the lake and then to divide the lake model into 1-m slices starting at the bottom of the lake and ending approximately $2 \mathrm{~m}$ above the lake's base elevation (static water-level elevation). The baselake elevation was obtained from 1:24,000 USGS topographic maps or from lake-level data from the Minnesota DNR Lake Finder Web site (Minnesota Department of Natural Resources, 2013d). All model grid cells represented in each 1-m slice were identified and converted to a GIS polygon dataset. All slice polygons were then compiled into a single polygon GIS dataset, and the area of each polygon was calculated by the GIS. Each lake model also included the area of land that would become inundated if the water level increased by $2 \mathrm{~m}$ above the lake's static water-level elevation.

After completion of the GIS polygon dataset, each lake was segmented into lateral segments (figs. 8-10). Within each lateral segment, 1-m layers were drawn from the bottom of the lake up to $2 \mathrm{~m}$ above the static lake-level elevation. Distance along the longitudinal axis for individual CE-QUAL-W2 lateral segments varied considerably. Considerations for the number of segments selected included a balance between

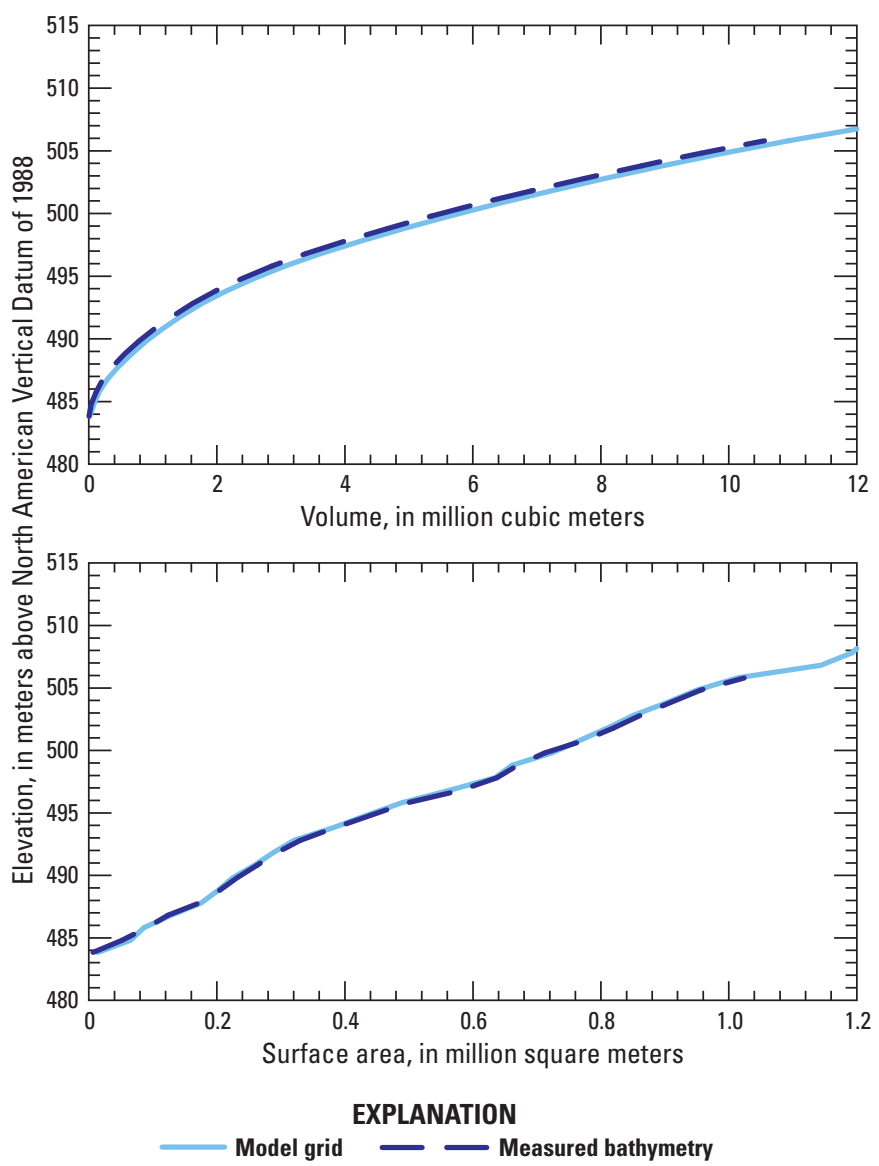

Figure 7. Lake volume and lake-surface area to water-surface elevation for Trout Lake using the measured bathymetry (Minnesota Geospatial Information Office, 2013a) and as represented by the model grid.

full-scale representation of the real structure of the lake and a segment structure that avoids numerical instability. Segments were grouped together into branches, with all of the branches grouped together representing the computational grid of the water body. Despite the ability to use different branches to represent separate bays or embayments, such as the northern end of Lake Carlos (fig. 2), these embayments or arms were included into a single water branch for the sake of model simplicity for all three lakes. Figures 8-10 show each of the three lakes in top and side view as the CE-QUAL-W2 computational grids. In reality, deeper layers get smaller and would also vary from segment to segment. Lake Carlos includes 22 computational segments (fig. 8), Elk Lake includes 5 computational segments (fig. 9), and Trout Lake includes 3 computational segments (fig. 10).

\section{Boundary and Initial Conditions}

The success of the model largely depended on a high data density of biological, chemical, and physical lake characteristics from which lake parameters could be calculated, and the model could be calibrated and validated. Several continuous 


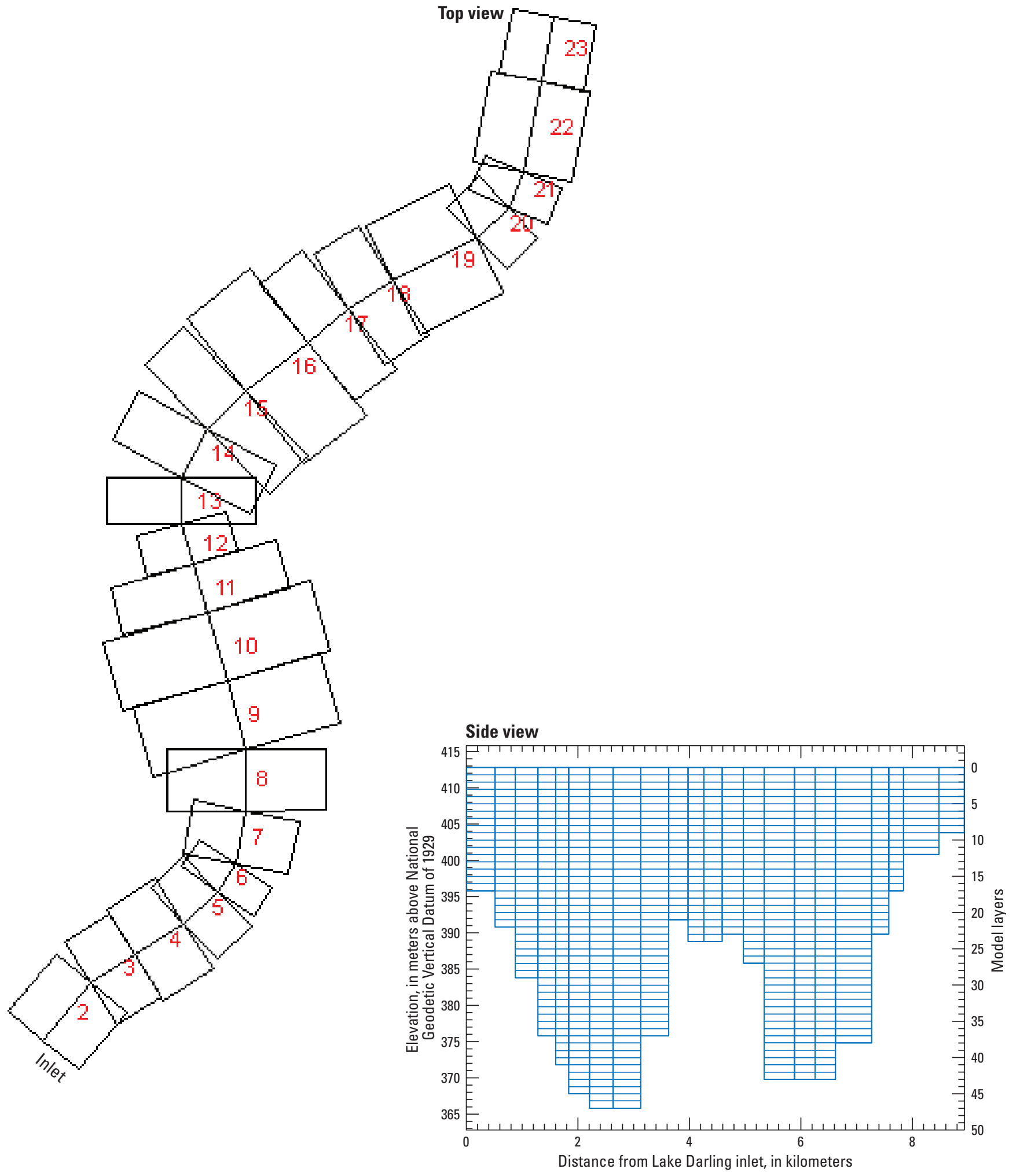

Figure 8. Computational grid for the CE-QUAL-W2 model for Lake Carlos. $A$, top view and $B$, side view. 


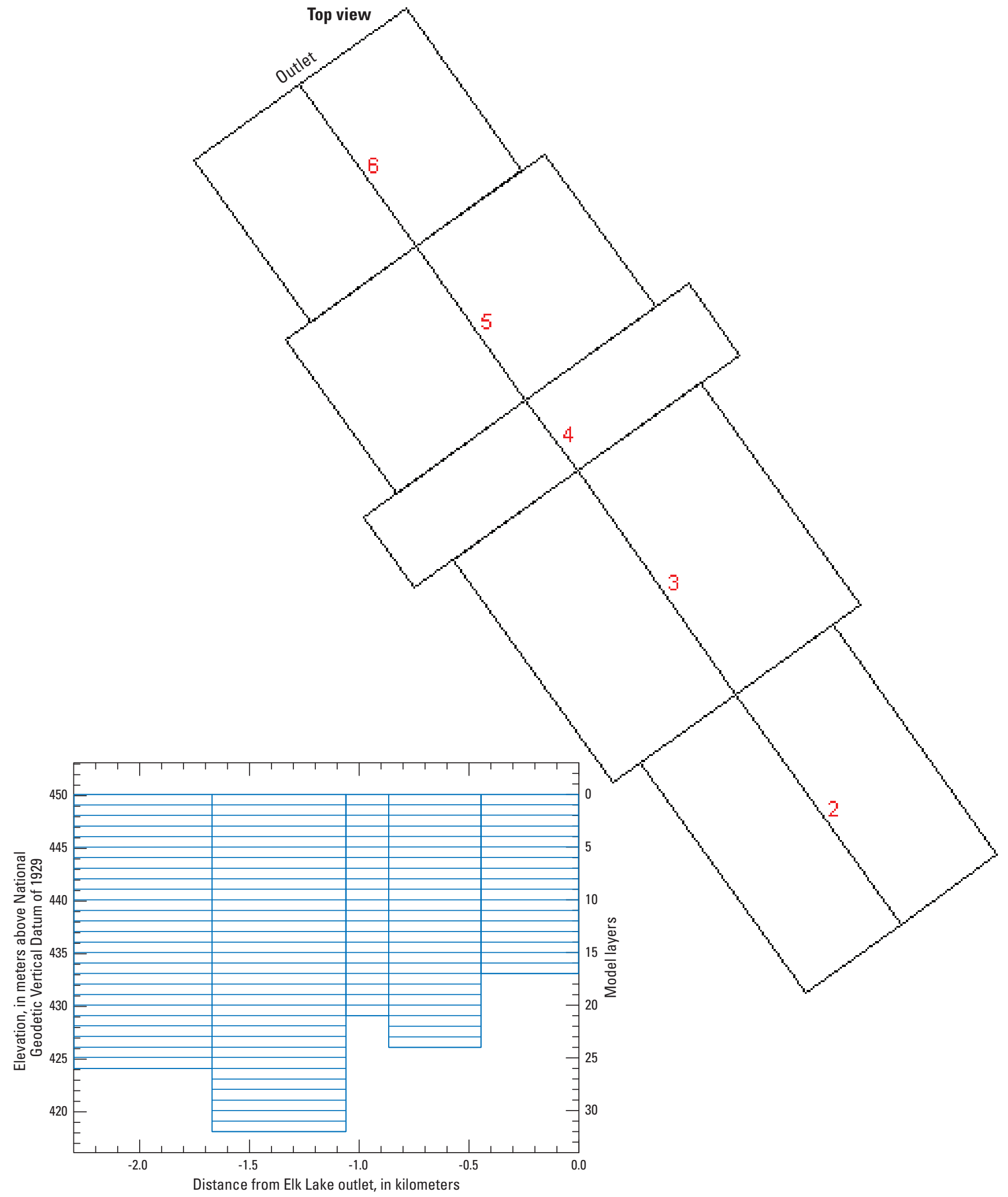

Figure 9. Computational grid for the CE-QUAL-W2 model for Elk Lake. $A$, top view and $B$, side view. 

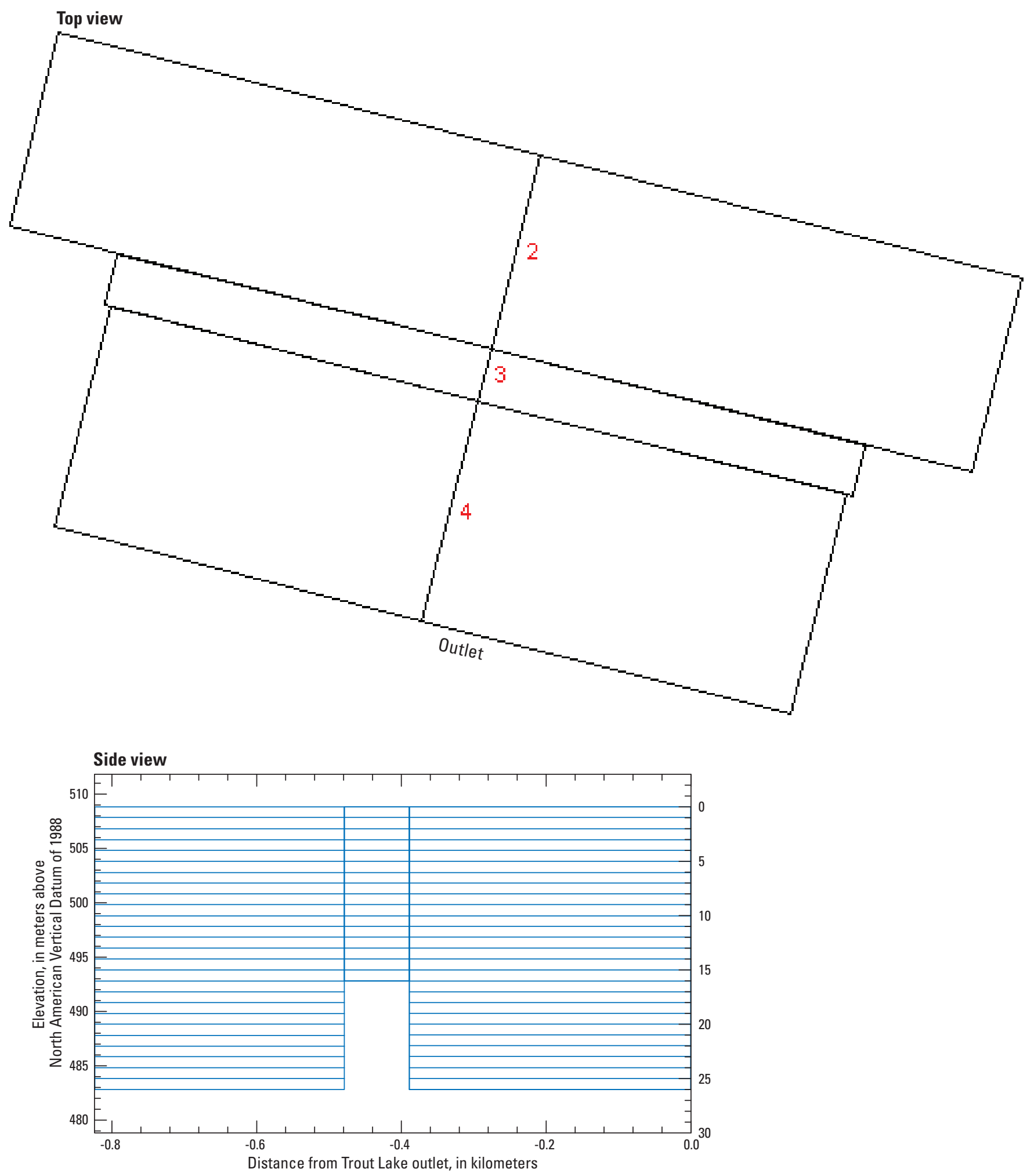

Figure 10. Computational grid for the CE-QUAL-W2 model for Trout Lake. $A$, top view and $B$, side view. 
flow and water-quality monitoring systems were installed to calculate the initial and boundary conditions for the models and to provide a robust calibration and validation dataset. Streamflow was measured monthly at the inflows and outflows of all three lakes. Streamflow measurements were made according to methods described in Buchanan and Somers (1969) and Mueller and Wagner (2008). Continuous streamflow and water temperature were collected for selected inflows and all outflows. A long, polyvinyl chloride (PVC) tube was submerged along the channel bed with a submersible, vented pressure transducer. The PVC tube was slightly elevated off the channel bed to avoid sedimentation. The enclosed pressure transducer measured water level and water temperature. A small enclosure was installed along the channel bank for ease of access to conduct bimonthly calibration and downloads. Further discussion of the continuous water levels is given in the "Hydraulic and Thermal Boundary Conditions" section. All streamflow (discharge) and water-temperature data collected for calibration and validation of the models are available from the USGS National Water Information System Web interface using the station numbers provided in table 1 (U.S. Geological Survey, 2013b).

The following sections detail the specific hydraulic and thermal boundary conditions, water-quality data collection and laboratory analyses, lake profile data, and chemical boundary conditions for each of the three lakes (Carlos, Elk, and Trout). Initial conditions also are described.

\section{Hydraulic and Thermal Boundary Conditions}

The following subsections describe the collection of water-level (stage) measurements, streamflow (discharge) measurements, temperature data, and meteorological data at each of the lakes. These data were used as hydraulic and thermal boundary conditions in the model.

\section{Lake Carlos}

Lake-inflow and water-temperature data used in the CEQUAL-W2 model for Lake Carlos were obtained from two separate channels into Lake Carlos. The Lake Darling outlet discharge was measured in the channel connecting Lake Darling to Lake Carlos, located at the southern end of Lake Carlos (table 1; fig. 2). Lake Le Homme Dieu outlet discharge was measured in the channel connecting Lake Le Homme Dieu to Lake Carlos, located along the eastern margin of Lake Carlos in the southern basin (fig. 2; table 1). Submersible pressure transducers were installed at ice off and removed just before ice on for Lake Darling and Le Homme Dieu outlets. While in operation, these transducers collected continuous water temperature and water-level (stage) measurements every 15 minutes. Discharge was measured monthly at these two inflow sites. Based on a linear regression analysis that estimates discharge from stage (Rantz and others, 1982a, 1982b), discharge estimates for every 15 minutes were made for the Lake Darling and Lake Le Homme Dieu outlets. For the purposes of the model, the Lake Darling outlet is considered the main inflow, flowing into segment 2, and Lake Le Homme Dieu is a tributary flowing into segment 5 (fig. 8; table 1). Additional water inflows to Lake Carlos also were assumed from ungaged locations in the lake and from groundwater flow, known as distributed flow. This was input into the model in daily time steps and distributed evenly across all the model segments; more detail of the distributed flow is provided in the "Water Balance" section of the model calibration.

The main outflow from Lake Carlos occurs through the Long Prairie River, located along the eastern margin of the northern basin (table 1; fig. 2). Stage and temperature data were collected upstream from a metal weir at the source of the Long Prairie River. Similar to the methods for both of the inflow sites, high-resolution (15-minute) discharge estimates at this outflow site were based on a rating curve constructed from comparisons between transducer water levels recorded every 15 minutes and monthly streamflow measurements (Rantz and others, 1982a, 1982b). Because this outflow site was not located in segment 23 , the final segment of the main water body branch, the outflow was treated as a withdrawal from segment 22 where the Long Prairie River site was located. Additionally, temperature data also were collected every 15 minutes. Water-surface elevations for Lake Carlos were based on the transducer record collected at the Long Prairie River site.

Meteorological data are required as input to the CEQUAL-W2 model because of the importance of surface boundary conditions to the overall behavior of the model, specifically surface heat exchange, solar radiation absorption, wind stress, and gas exchange. Required meteorological data include air temperature, dew point temperature, wind speed, wind direction, and cloud cover. All unit conversions from the meteorological data to the required units for the model were straightforward with the exception of cloud cover. The qualitative sky cover parameter (that is, clear, scattered, broken, and overcast) was converted to an integer value ranging from 0 to 10: clear is 0 , scattered ( $1 / 8$ to $1 / 2$ cloud coverage) is 3 , broken ( $5 / 8$ to $7 / 8$ cloud coverage) is 7 , and overcast is 10 . All of the required data generally were available at hourly intervals for the Alexandria Municipal Airport (U.S. Air Force [USAF] station identification number [ID] 726557) from the Climate Data Online portal (National Climatic Data Center, 2013), located less than $10 \mathrm{~km}$ south of Lake Carlos. Based on the latitude and longitude of the lake and the required meteorological inputs, evapotranspiration was included in the water balance as an internal CE-QUAL-W2 calculation.

\section{Elk Lake}

Outflows from Elk Lake were used in the calculation of inflows to Elk Lake, so outflows are described first. The main outflow from Elk Lake occurred through the Elk Lake outlet, located at the northwestern end of Elk Lake, which discharges water to Lake Itasca (fig. 3; table 1). Similar to the methods described for Lake Carlos, high-resolution (15-minute) 
discharge estimates were based on linear regression equations constructed from comparisons between transducer water levels (stage) recorded every 15 minutes and monthly streamflow measurements made at the Elk Lake outlet. Slight differences in the stage transformation to discharge for Elk Lake included the linear regression analysis performed as a power trendline equation on a $\log / \log$ scale between stage and discharge. Also, the stage data included an adjustment for the point of zero flow. Additionally, temperature data also were collected every 15 minutes. Water-surface elevation for Elk Lake was based on the transducer record collected at the Elk Lake outlet.

Lake inflow data were not collected for Elk Lake. Instead, the inflows to Elk Lake were computed from the outflow record. Four distinct ungaged inflow sites (UTEL1, Ga-Gwa-Dosh Creek, UTEL2, and Siegfried Creek) were identified around Elk Lake (fig. 3; table 1). The contributing drainage basin for each of the four ungaged inflow sites was determined using the USGS Minnesota StreamStats application (Ries and others, 2005; Lorenz and others, 2009). The amount of expected discharge from each of the four ungaged inflow sites was calculated by dividing the contributing basin area for the ungaged inflow site by the overall contributing basin area for Elk Lake and multiplying this percentage by the outflow record. This assumed the entire watershed contributed equally at all times, and the instantaneous outflow was the same as the sum of all the instantaneous inflows minus evapotranspiration. Although these assumptions were not necessarily true, this method was the best approximation available for inflows and for apportioning the inflows into the different segments (fig. 3; fig. 9).

All of the required meteorological data generally were available at hourly intervals for the Park Rapids Municipal Airport (USAF station ID 727543) from the Climate Data Online portal (National Climatic Data Center, 2013), located approximately $33 \mathrm{~km}$ southeast of Elk Lake. A weather station was installed at Elk Lake in June 2011 by the USGS that records wind speed and direction; wind data from the Elk Lake weather station were used in lieu of the Park Rapids wind data whenever available. The meteorological data required for the Elk Lake CE-QUAL-W2 model were the same as those described in the previous section for Lake Carlos.

\section{Trout Lake}

Similar to Elk Lake, outflows from Trout Lake were used in the calculation of inflows to Trout Lake, so outflows are described first. The main outflow from Trout Lake occurs through the Trout Lake outlet, located at the southern end of Trout Lake (fig. 4). Similar to the methods described for Lake Carlos and Elk Lake, high-resolution (15-minutes) discharge estimates were made based on a linear regression analysis constructed from comparisons between transducer water levels recorded every 15 minutes and monthly streamflow measurements. Additionally, temperature and water-surface elevation data also were collected every 15 minutes.
Following the same approach used for Elk Lake, the inflows to Trout Lake were computed from the outflow record; for additional details on allocating the inflows from the outflow record, see the previous "Elk Lake" section. Two distinct ungaged inflow sites (Trout Lake tributary and Marsh Lake outlet) were identified around Trout Lake (fig. 4; table 1).

All of the required meteorological data generally were available at hourly intervals for the Grand Marais-Cook County Municipal Airport (USAF station ID 727454) from the Climate Data Online portal (National Climatic Data Center, 2013), located approximately $14 \mathrm{~km}$ southwest of Trout Lake. The meteorological data requirements for the Trout Lake CE-QUAL-W2 model were the same as those previously described for Lake Carlos.

\section{Water-Quality Data Collection, Vertical Profiles and Laboratory Analyses}

Limnological characteristics, including properties that could affect trophic state, were examined at one limnological site for each of the three lakes (table 1): Lake Carlos at Kecks Point, Elk Lake at the south basin hole, and Trout Lake at the north basin hole. The sites were sampled monthly from May through November 2010 and March through October 2011 by the USGS and the Minnesota Pollution Control Agency (MPCA) staff with the same schedule but with a 2-week offset, so that biweekly sampling was accomplished for both the 2010 and 2011 field seasons for selected parameters. Samples were collected near the surface and at depth, respectively $(1 \mathrm{~m}$ and $20 \mathrm{~m}$ in Lake Carlos, $2 \mathrm{~m}$ and $20 \mathrm{~m}$ in Elk Lake, $1 \mathrm{~m}$ and $18 \mathrm{~m}$ in Trout Lake), using a Kemmerer (Lind, 1974) or Van Dorn (Van Dorn, 1956) sampler and were analyzed to determine concentrations of alkalinity, nutrients, major ions, and chlorophyll $a$. Water samples were filtered and preserved as required. Alkalinity was determined by incremental titration at the field laboratory. Secchi-disk transparency (Wetzel, 2001) was measured at each vertical profile location to estimate photic depth. Vertical profiles (1-m intervals) of temperature, DO concentration, $\mathrm{pH}$, and specific conductance were measured with a multiparameter YSI sonde (YSI model 6920) at each lake site in conjunction with the water samples, following the methods for field measurements in still water presented in Wilde and Radtke (1998). The USGS and MPCA followed the same methodology for the vertical profiles.

Sampling also was conducted by the USGS at the inflows and outflows for each of the three lakes (table 1). The same constituents and methodologies as the limnological sites were followed for these sites. Sampling frequency for the inflows and outflows varied between the three different lakes. For Lake Carlos, inflow and outflow sampling occurred on approximately a monthly basis. For Elk Lake, inflows were sampled opportunistically and outflow was sampled about 4-5 times per year. For Trout Lake, inflow and outflow was sampled approximately six times for each location over the course of the 2 years. 
Water samples collected by the USGS at the lake, inflow, and outflow sites were analyzed by the USGS National Water Quality Laboratory (NWQL) in Denver, Colorado, and water samples collected by the MPCA were analyzed by the Minnesota Department of Health Environmental Laboratory (DHEL) in St. Paul, Minn. Method information, NWQL long-term method detection limits, and Minnesota DHEL method detection limits for constituents analyzed for Lake Carlos, Elk Lake, and Trout Lake are given in table 2. Dissolved concentrations are those analyzed for a 0.45 -micron filtered sample, whereas total concentrations were determined for a whole water sample. All of the samples analyzed by NWQL have been previously reviewed, published, and are available online through the National Water Information System (NWIS) water-quality portal by searching for the station number in table 1 (U.S. Geological Survey, 2013b). All of the samples analyzed by the Minnesota DHEL have been previously reviewed, published, and are available online at the Minnesota
DNR Lake Finder by searching for the lake number (Lake Carlos is 21005700, Elk Lake is 15001000 , and Trout Lake is 16004900 ) and the subcategory of lake water quality (Minnesota Department of Natural Resources, 2013d).

A primary data-quality objective was to ensure that samples were representative of the water bodies under investigation. Quality assurance was assessed with specific procedures, such as instrument calibration, to ensure data reliability and assess the quality of the sample data. The quality-assurance plan for this study followed USGS guidelines (Brunett and others, 1997). Field instruments were maintained according to manufacturer's guidelines, calibration standards were properly stored, calibration for portable field instruments was undertaken at the start of each day (Gibs and others, 2012), and all field sampling equipment was cleaned before use according to the National Field Manual guidelines (Wilde, 2004). Additional quality assurance specific to NWQL is available online (U.S. Geological Survey, 2013c). Additional quality

Table 2. Water-quality methods for constituents analyzed in water samples from Lake Carlos, Elk Lake, and Trout Lake, 2010-11.

[mg/L, milligrams per liter; -, not analyzed; $\mu \mathrm{g} / \mathrm{L}$, micrograms per liter $]$

\begin{tabular}{|c|c|c|c|c|}
\hline \multirow[b]{2}{*}{ Constituent } & \multicolumn{2}{|l|}{ National Water Quality Laboratory } & \multicolumn{2}{|c|}{$\begin{array}{l}\text { Minnesota Department of } \\
\text { Health Environmental Laboratory }\end{array}$} \\
\hline & Method & $\begin{array}{c}\text { Long-term } \\
\text { method } \\
\text { detection limit }^{1}\end{array}$ & Method & $\begin{array}{l}\text { Method } \\
\text { detection } \\
\text { limit }^{2}\end{array}$ \\
\hline Dissolved nitrite, as nitrogen & Colorimetry (Fishman, 1993) & $0.0010 \mathrm{mg} / \mathrm{L}$ & - & - \\
\hline $\begin{array}{l}\text { Dissolved nitrate plus nitrite } \\
\text { nitrogen }\end{array}$ & $\begin{array}{l}\text { Colorimetry, enzyme reduction-diazotization } \\
\text { (Patton and Kryskalla, 2011) }\end{array}$ & $0.01 \mathrm{mg} / \mathrm{L}$ & - & - \\
\hline Dissolved ammonia, as nitrogen & $\begin{array}{l}\text { Colorimetry, salicylate-hypochlorate (Fish- } \\
\text { man, 1993) }\end{array}$ & $0.010 \mathrm{mg} / \mathrm{L}$ & - & - \\
\hline Total nitrogen & $\begin{array}{l}\text { Colorimetry, microkjeldahl digestion (Patton } \\
\text { and Truit, 2000) }\end{array}$ & $\mathrm{mg} / \mathrm{L}$ & $\begin{array}{l}\text { EPA } 351.2 \text { (U.S. Environ- } \\
\text { mental Protection Agency, } \\
\text { 1993) }\end{array}$ & $0.20 \mathrm{mg} / \mathrm{L}$ \\
\hline $\begin{array}{l}\text { Dissolved ammonia plus organic } \\
\text { nitrogen, as nitrogen }\end{array}$ & $\begin{array}{l}\text { Colorimetry, microkjeldahl digestion (Patton } \\
\text { and Truitt, 2000) }\end{array}$ & $\mathrm{mg} / \mathrm{L}$ & - & - \\
\hline Dissolved phosphorus & $\begin{array}{l}\text { EPA } 365.1 \text { (U.S. Environmental Protection } \\
\quad \text { Agency, 1993) }\end{array}$ & $0.003 \mathrm{mg} / \mathrm{L}$ & - & - \\
\hline Dissolved orthophosphorus & $\begin{array}{l}\text { Colorimetry, phosphomolybdate (Fishman, } \\
\text { 1993) }\end{array}$ & $0.004 \mathrm{mg} / \mathrm{L}$ & - & - \\
\hline Chlorophyll $a$ & Fluorometric (Arar, 1997) & $\mu \mathrm{g} / \mathrm{L}$ & $\begin{array}{l}\text { Spectrophotometric (Ameel } \\
\quad \text { and others, 1998) }\end{array}$ & $\mu \mathrm{g} / \mathrm{L}$ \\
\hline Total dissolved solids & $\begin{array}{l}\text { Residue on evaporation (Fishman and Fried- } \\
\text { man, 1989) }\end{array}$ & $\mathrm{mg} / \mathrm{L}$ & - & - \\
\hline Total silica, as silicon dioxide & $\begin{array}{l}\text { Inductively coupled plasmaatomic emission } \\
\text { spectroscopy (Fishman, 1993) }\end{array}$ & $0.018 \mathrm{mg} / \mathrm{L}$ & - & - \\
\hline Dissolved iron & $\begin{array}{l}\text { Inductively coupled plasmaatomic emission } \\
\text { spectroscopy (Fishman, 1993) }\end{array}$ & $0.0010 \mathrm{mg} / \mathrm{L}$ & - & - \\
\hline
\end{tabular}

\footnotetext{
${ }^{1}$ The long-term method detection level is derived by determining the standard deviation of a minimum of 24 method detection limit spike sample measurements for an extended time (Childress and others, 1999).

${ }^{2}$ The minimum detection limit is the minimum concentration of a substance that can be measured and reported with a 99 -percent confidence that the analyte concentration is greater than 0 (U.S. Environmental Protection Agency, 2002).
} 
assurance specific to Minnesota DHEL is available online (Minnesota Department of Health, 2013). Results from available quality-assurance data associated with water-quality data used for input to the model and for calibration and validation of the model were reviewed prior to the modeling efforts. Overall, the water-quality datasets (discrete samples collected at specific streamflow or lake elevations) for the calibration and validation periods were considered appropriate for the range of environmental conditions simulated for this report. Split samples to test for water-quality reproducibility between NWQL and DHEL were not collected for this study. However, the water-quality data from DHEL were used specifically for calibration and validation purposes only, rather than for model development.

\section{Lake Profile Data}

Buoys with attached thermistor chains were installed in each lake in the spring 2010 and remained in the lake through 2012 ice off. The thermistor chains were made up of HOBO Water Temp Pro v2 Loggers attached to braided nylon rope with clips. The buoys were designed to float on the water surface during the 2010 ice-free season and were then submerged 1-2 m below water surface through the 2010-11 winter and remained submerged for the duration of deployment. Thermistors were spaced at equal intervals from 1.5 to $3 \mathrm{~m}$ (depending on the lake) through the 2010 ice-free season and then adjusted to a tighter interval of $1 \mathrm{~m}$ around the thermocline with broader thermistor spacing in the hypolimnion. The HOBO thermistors continuously logged temperature at 15-minute intervals. In Lake Carlos, the thermistor chain was located at Kecks Point; in Elk Lake, the thermistor chain was located at the south basin hole; in Trout Lake, the thermistor chain was located at the north basin hole.

In addition to the thermistor chain data, Elk Lake had multiparameter YSI sondes (YSI model 6920) measuring continuous temperature and DO concentration at fixed depths in the south basin hole for 2011. The procedures of Wagner and others (2006) were followed for the long-term deployment of the multiparameter probes. These continuous temperature and DO concentrations were used as additional calibration targets for Elk Lake in 2011.

\section{Initial Conditions}

All three lakes had water-quality modeling incorporated into a hydrodynamic model. Each simulated constituent (including temperature) must have an initial, single concentration for the entire lake or a gridwide initial vertical profile of concentrations at the start of each model run. Initial conditions for each of the three lakes are shown in table 3, broken up by the calibration and validation years. Because Lake Carlos had a more robust water-quality dataset than the other two lakes, separate initial conditions for all of the parameters were provided for the calibration and validation years. Elk Lake and
Trout Lake had the same initial conditions with the exception of the water-surface elevation, initial temperature, DO, and algal group concentrations. Initial constituent concentrations were considered uniform throughout the lake for every segment and layer, except in cases with a reported range of values in a vertical profile, based on the long-term averages at the following locations: Lake Carlos at Kecks Point; Elk Lake at the south basin hole; and Trout Lake at the north basin hole. For a vertical profile, the highest value is at the surface layer and the lowest value at the bottom layer, with interpolated values in between for each of the intervening layers. Initial water-surface elevation and water temperature was set to the measured value at the start of the simulations for all three lakes.

\section{Chemical Boundary Conditions}

Each simulated water-quality constituent, including total dissolved solids, nutrients, silica, iron, organic matter, and inorganic carbon must have a daily concentration value for all inflow tributaries (including distributed tributary flow). Depending on the frequency of discrete water-quality samples, the input constituent concentrations for all calibration and validation runs were either transformed into daily load estimates, an average daily concentration value was linearly interpolated between the discrete samples for each inflow tributary, or a single concentration was applied for the entire model run for each inflow tributary. In cases with available daily load estimates, the load estimates were transformed back into daily constituent concentrations based upon the daily average tributary discharge. For Lake Carlos, a subset of constituents had sufficient data for daily load estimates for both tributary sites, with the remaining constituents linearly interpolated between the available concentration data. The Lake Carlos distributed tributary inflow constituents were based upon the average concentrations between the Lake Darling outlet and Lake Le Homme Dieu outlet. In the cases of Elk Lake and Trout Lake, sufficient water-quality data were not available for load estimates. For Elk Lake inflow tributaries, a single concentration for each constituent was applied for the entire model run. The Elk Lake distributed tributary inflow constituents were based upon the average concentrations of unnamed spring to Elk Lake near Hubbard, Minn. (USGS station number 471123095132901). For Trout Lake, an average daily concentration value was linearly interpolated between the discrete water-quality samples for both the Trout Lake tributary and Marsh Lake outlet. The Trout Lake distributed tributary inflow water-quality constituent data were based upon the average constituent concentrations between the Trout Lake tributary and Marsh Lake outlet.

For Lake Carlos, load estimates were available for both tributary sites (Lake Darling outlet and Lake Le Homme Dieu outlet) for the following constituents: ammonia, nitrate plus nitrite, and orthophosphorus. The S-LOADEST computer program (Runkel and others, 2004) was used to estimate daily loads for the calibration and validation periods by using the loads determined from the discrete samples. Constituent 
Table 3. Initial constituent concentrations of calibration and validation runs for the Lake Carlos, Elk Lake, and Trout Lake models. [m, meters; NGVD 29, National Geodetic Vertical Datum of 1929; NAVD 88, North American Vertical Datum of 1988; mg/L, millgrams per liter; ${ }^{\circ} \mathrm{C}$, degrees Celsius]

\begin{tabular}{|c|c|c|c|c|c|c|}
\hline \multirow[b]{2}{*}{ Constituent } & \multicolumn{3}{|c|}{ Calibration value } & \multicolumn{3}{|c|}{ Validation value } \\
\hline & $\begin{array}{l}\text { Lake Carlos, } \\
\text { in m above } \\
\text { NGVD } 29 \\
(2010)\end{array}$ & $\begin{array}{c}\text { Elk Lake, } \\
\text { in } \mathrm{m} \text { above } \\
\text { NGVD } 29 \\
(\mathbf{2 0 1 1 )}\end{array}$ & $\begin{array}{c}\text { Trout Lake, } \\
\text { in m above } \\
\text { NAVD } 88 \\
(2010)\end{array}$ & $\begin{array}{c}\text { Lake Carlos, } \\
\text { in } \mathrm{m} \text { above } \\
\text { NGVD } 29 \\
\text { (2011) }\end{array}$ & $\begin{array}{c}\text { Elk Lake, } \\
\text { in } \mathrm{m} \text { above } \\
\text { NGVD } 29 \\
\text { (2010) }\end{array}$ & $\begin{array}{c}\text { Trout Lake, } \\
\text { in } \mathrm{m} \text { above } \\
\text { NAVD } 88 \\
(2011)\end{array}$ \\
\hline Initial water-surface elevation, $\mathrm{m}$ & 413.58 & 448.08 & 505.69 & 413.53 & 447.98 & 505.86 \\
\hline Total dissolved solids, mg/L & 258.97 & 172.23 & 29.68 & 255.58 & 172.23 & 29.68 \\
\hline Ammonia, mg/L & 0.0234 & 0.329 & 0.0109 & 0.0241 & 0.329 & 0.0109 \\
\hline Nitrate-nitrite, $\mathrm{mg} / \mathrm{L}$ & 0.0348 & 0.015 & 0.0183 & 0.0686 & 0.015 & 0.0183 \\
\hline Dissolved silica, mg/L & 6.9983 & 10.7815 & 6.4142 & 7.697 & 10.7815 & 6.4142 \\
\hline Particulate silica, mg/L & 1 & 1 & 1 & 1 & 1 & 1 \\
\hline Total iron, mg/L & 0.0002 & 0.0073 & 0.0109 & 0.0002 & 0.0073 & 0.0109 \\
\hline Labile dissolved organic matter (DOM), mg/L & 1.8736 & 2.0877 & 1.5349 & 1.7206 & 2.0877 & 1.5349 \\
\hline Green algae, mg/L & 0.1 & 0.1 & 0.2 & 0.1 & 0.1 & 0.2 \\
\hline Blue-green algae, mg/L & 0.1 & 0.2 & 0.1 & 0.1 & 0.1 & 0.1 \\
\hline Dissolved oxygen, $\mathrm{mg} / \mathrm{L}$ & 6 & $12.0-4.9$ & $17.3-9.4$ & 7.86 & ${ }^{1} 0.0-9.3$ & 9.7 \\
\hline Inorganic carbon, $\mathrm{mg} / \mathrm{L}$ & 194.4 & 185.1 & 20.5 & 195.6 & 185.1 & 20.5 \\
\hline Alkalinity, $\mathrm{mg} / \mathrm{L}$ & 163.8 & 152.3 & 15.8 & 165.3 & 152.3 & 15.8 \\
\hline Initial temperature, ${ }^{\circ} \mathrm{C}$ & 4 & 4.1 & 7.5 & 3 & ${ }^{1} 5.4-24.1$ & ${ }^{1} 4.6-10.0$ \\
\hline Sediment temperature, ${ }^{\circ} \mathrm{C}$ & 4 & 8 & 7.7 & 4 & 8 & 7.7 \\
\hline
\end{tabular}

${ }^{1}$ Initial constituent concentrations were considered uniform throughout the lake for every segment and layer, except in cases with a reported range of values, which constitutes a vertical profile. The highest value is at the surface layer, with the lowest value at the bottom layer, with interpolated values in between for each of the layers.

concentration from discrete sampling was transformed into load estimates using discharge and an adjusted maximum likelihood estimator (AMLE) or a least absolute deviation (LAD) (Cohn and others, 1992). The AMLE method was used if the constituent had censored values, and the LAD method was used to transform the results if no censored values were included in the data or if outliers in the residuals were present. The LAD method was applied for ammonia and orthophosphorus for both tributary sites, and the AMLE method was applied for nitrate plus nitrite for both tributary sites.

\section{Model Parameters}

Numerous CE-QUAL-W2 models have shown that the default hydraulic parameters are robust across different hydrologic settings and are relatively insensitive to variations (Cole and Wells, 2008). In these three lake models, the default hydraulic parameters that control the hydrodynamics and heat exchange provided within CE-QUAL-W2 V3.6 or the accompanying manual were followed. The density control for all inflows in the model allowed for the water inflows to match up with the layers within the lake that corresponded to the inflow density. It is important to note that CE-QUAL-W2 is time and space invariant.

For the water-quality algorithms, more than 130 parameters control the constituent kinetics (table 4). An advantage of CE-QUAL-W2 is the modular design that allows for control of the water-quality constituents by adding specific subroutines. Many of these parameters were optional depending on the inclusion of groups such as epiphyton, zooplankton, macrophytes, and algae. Only the parameters required for the lake applications were included in table 4 . As with the hydraulic and heat exchange parameters that control the hydrodynamics, all of the parameters were time and space invariant. The option exists to vary some parameters, such as the extinction coefficient of water; however, not enough data were collected to justify dynamic control of any parameters.

Many of the parameters in table 4 were left as the default values (57 parameters), whereas the remaining parameters (74 parameters) were adjusted within a reasonable range during the calibration process for at least one of the three lake models. Guidance for adjusting selected parameters also came from other USGS CE-QUAL-W2 model applications (Green and others, 2003; Sullivan and Rounds, 2004; Galloway and Green, 2006; Galloway and others, 2008; Sullivan and others, 2011). 
Table 4. Parameters used in the water-quality algorithms for Lake Carlos, Elk Lake, and Trout Lake.

$\left[\mathrm{m}^{-1}\right.$, per meter; $\mathrm{g} \cdot \mathrm{m}^{-3}$, grams per cubic meter; day ${ }^{-1}$, per day; $\mathrm{m} \cdot \mathrm{day}^{-1}$, meters per day; $\mathrm{W} \cdot \mathrm{m}^{-2}$, watts per square meter; ${ }^{\circ} \mathrm{C}$, degrees $\mathrm{Celsius} ; \mathrm{m} \cdot \mathrm{s}^{-1} ; \mathrm{meters}$ per second; $\mathrm{g} \mathrm{m}^{-2} \cdot \mathrm{day}^{-1}$, grams per square meter per day; bold text indicates parameters adjusted from default value]

\begin{tabular}{|c|c|c|c|c|}
\hline \multirow{2}{*}{ Parameter } & \multirow{2}{*}{ Description } & \multicolumn{3}{|c|}{ Parameter value } \\
\hline & & Lake Carlos & Elk Lake & Trout Lake \\
\hline EXH2O & Light extinction for pure water, $\mathrm{m}^{-1}$ & 0.45 & 0.45 & 0.25 \\
\hline EXOM & Light extinction due to organic suspended solids, $\mathrm{m}^{-1}$ & 0.05 & 0.05 & 0.01 \\
\hline BETA & Fraction of incident solar radiation absorbed at water surface & 0.38 & 0.45 & 0.45 \\
\hline EXA1 & Light extinction due to algae (diatoms), $\mathrm{m}^{-1} /\left(\mathrm{g} \cdot \mathrm{m}^{-3}\right)$ & 0.25 & 0.2 & 0.2 \\
\hline AG & Maximum algal growth rate (diatoms), day ${ }^{-1}$ & 2.3 & 2.3 & 2.3 \\
\hline AG & Maximum algal growth rate (green), day ${ }^{-1}$ & 2.1 & 2.1 & 2.1 \\
\hline AG & Maximum algal growth rate (blue-green), day ${ }^{-1}$ & 2.0 & 2.0 & 2.0 \\
\hline AR & Maximum algal respiration rate (diatoms), day ${ }^{-1}$ & 0.04 & 0.04 & 0.02 \\
\hline AR & Maximum algal respiration rate (green), day ${ }^{-1}$ & 0.04 & 0.04 & 0.02 \\
\hline $\mathrm{AM}$ & Maximum algal mortality rate (diatoms), day ${ }^{-1}$ & 0.1 & 0.12 & 0.04 \\
\hline AM & Maximum algal mortality rate (green), day ${ }^{-1}$ & 0.1 & 0.03 & 0.07 \\
\hline $\mathrm{AM}$ & Maximum algal mortality rate (blue-green), day ${ }^{-1}$ & 0.15 & 0.07 & 0.12 \\
\hline AS & Algal settling rate (diatoms), $\mathrm{m} \cdot$ day $^{-1}$ & 0.18 & 0.15 & 0.05 \\
\hline AS & Algal settling rate (green), $\mathrm{m} \cdot$ day $^{-1}$ & 0.18 & 0.15 & 0.07 \\
\hline AS & Algal settling rate (blue-green), $\mathrm{m} \cdot$ day $^{-1}$ & 0.18 & 0.15 & 0.15 \\
\hline AHSP & Algal half-saturation for phosphorus limited growth (diatoms), $\mathrm{g} \cdot \mathrm{m}^{-3}$ & 0.002 & 0.004 & 0.001 \\
\hline AHSP & Algal half-saturation for phosphorus limited growth (green), $\mathrm{g} \cdot \mathrm{m}^{-3}$ & 0.003 & 0.0018 & 0.003 \\
\hline AHSP & Algal half-saturation for phosphorus limited growth (blue-green), $\mathrm{g} \cdot \mathrm{m}^{-3}$ & 0.002 & 0.002 & 0.003 \\
\hline AHSN & Algal half-saturation for nitrogen limited growth (diatoms), $\mathrm{g} \cdot \mathrm{m}^{-3}$ & 0.03 & 0.03 & 0.023 \\
\hline AHSN & Algal half-saturation for nitrogen limited growth (green), $\mathrm{g} \cdot \mathrm{m}^{-3}$ & 0.03 & 0.012 & 0.012 \\
\hline AT1 & Lower temperature for algal growth (diatoms), ${ }^{\circ} \mathrm{C}$ & 5 & 5 & 5 \\
\hline AT1 & Lower temperature for algal growth (green), ${ }^{\circ} \mathrm{C}$ & 10 & 10 & 10 \\
\hline AT1 & Lower temperature for algal growth (blue-green), ${ }^{\circ} \mathrm{C}$ & 13 & 13 & 13 \\
\hline AT2 & Lower temperature for maximum algal growth (diatoms), ${ }^{\circ} \mathrm{C}$ & 10 & 10 & 10 \\
\hline AT2 & Lower temperature for maximum algal growth (green), ${ }^{\circ} \mathrm{C}$ & 17 & 17 & 17 \\
\hline AT2 & Lower temperature for maximum algal growth (blue-green), ${ }^{\circ} \mathrm{C}$ & 20 & 20 & 20 \\
\hline AT3 & Upper temperature for maximum algal growth (diatoms), ${ }^{\circ} \mathrm{C}$ & 13 & 13 & 13 \\
\hline AT3 & Upper temperature for maximum algal growth (green), ${ }^{\circ} \mathrm{C}$ & 30 & 30 & 30 \\
\hline AT3 & Upper temperature for maximum algal growth (blue-green), ${ }^{\circ} \mathrm{C}$ & 32 & 32 & 32 \\
\hline AT4 & Upper temperature for algal growth (diatoms), ${ }^{\circ} \mathrm{C}$ & 25 & 25 & 25 \\
\hline AT4 & Upper temperature for algal growth (green), ${ }^{\circ} \mathrm{C}$ & 32 & 32 & 32 \\
\hline AT4 & Upper temperature for algal growth (blue-green), ${ }^{\circ} \mathrm{C}$ & 35 & 35 & 35 \\
\hline AK1 & Fraction of algal growth rate at AT1 (diatoms) & 0.1 & 0.1 & 0.1 \\
\hline AK1 & Fraction of algal growth rate at AT1 (green) & 0.1 & 0.1 & 0.1 \\
\hline AK1 & Fraction of algal growth rate at AT1 (blue-green) & 0.1 & 0.1 & 0.1 \\
\hline AK2 & Fraction of maximum algal growth rate at AT2 (diatoms) & 0.99 & 0.99 & 0.99 \\
\hline AK2 & Fraction of maximum algal growth rate at AT2 (green) & 0.99 & 0.99 & 0.99 \\
\hline AK2 & Fraction of maximum algal growth rate at AT2 (blue-green) & 0.99 & 0.99 & 0.99 \\
\hline
\end{tabular}


Table 4. Parameters used for the water-quality algorithms for Lake Carlos, Elk Lake, and Trout Lake.—Continued

$\left[\mathrm{m}^{-1}\right.$, per meter; $\mathrm{g} \cdot \mathrm{m}^{-3}$, grams per cubic meter; day ${ }^{-1}$, per day; $\mathrm{m} \cdot$ day ${ }^{-1}$, meters per day; $\mathrm{W} \cdot \mathrm{m}^{-2}$, watts per square meter; ${ }^{\circ} \mathrm{C}$, degrees Celsius; $\mathrm{m} \cdot \mathrm{s}^{-1} ; \mathrm{meters}$ per

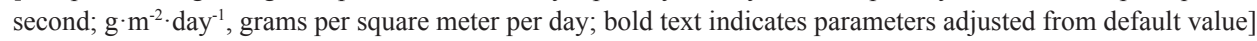

\begin{tabular}{|c|c|c|c|c|}
\hline \multirow{2}{*}{ Parameter } & \multirow{2}{*}{ Description } & \multicolumn{3}{|c|}{ Parameter value } \\
\hline & & Lake Carlos & Elk Lake & Trout Lake \\
\hline AK3 & Fraction of maximum algal growth rate at AT3 (diatoms) & 0.99 & 0.99 & 0.99 \\
\hline AK3 & Fraction of maximum algal growth rate at AT3 (blue-green) & 0.99 & 0.99 & 0.99 \\
\hline AK4 & Fraction of algal growth rate at AT4 (diatoms) & 0.1 & 0.1 & 0.1 \\
\hline AK4 & Fraction of algal growth rate at AT4 (green) & 0.1 & 0.1 & 0.1 \\
\hline ALGP & Stoichiometric equivalent between algal biomass and phosphorus (diatoms) & 0.0015 & 0.0018 & 0.002 \\
\hline ALGP & Stoichiometric equivalent between algal biomass and phosphorus (green) & 0.0015 & 0.0022 & 0.002 \\
\hline ALGP & Stoichiometric equivalent between algal biomass and phosphorus (blue-green) & 0.0015 & 0.0022 & 0.002 \\
\hline ALGN & Stoichiometric equivalent between algal biomass and nitrogen (diatoms) & 0.0825 & 0.07 & 0.08 \\
\hline ALGN & Stoichiometric equivalent between algal biomass and nitrogen (green) & 0.0825 & 0.07 & 0.072 \\
\hline ALGN & Stoichiometric equivalent between algal biomass and nitrogen (blue-green) & 0.0825 & 0.07 & 0.072 \\
\hline ALGSI & Stoichiometric equivalent between algal biomass and silica (green) & 0.18 & 0.18 & 0.18 \\
\hline ALGSI & Stoichiometric equivalent between algal biomass and silica (blue-green) & 0.18 & 0.18 & 0.18 \\
\hline ACHLA & $\begin{array}{l}\text { Ratio between algal biomass and chlorophyll } a \text { in terms of milligrams of algae } \\
\text { to micrograms of chlorphyll } a \text { (diatoms) }\end{array}$ & 0.1 & 0.28 & 0.12 \\
\hline ACHLA & $\begin{array}{l}\text { Ratio between algal biomass and chlorophyll } a \text { in terms of milligrams of algae } \\
\text { to micrograms of chlorphyll } a \text { (green) }\end{array}$ & 0.1 & 0.28 & 0.12 \\
\hline ACHLA & $\begin{array}{l}\text { Ratio between algal biomass and chlorophyll } a \text { in terms of milligrams of algae } \\
\text { to micrograms of chlorphyll } a \text { (blue-green) }\end{array}$ & 0.1 & 0.28 & 0.12 \\
\hline ALPOM & $\begin{array}{l}\text { Fraction of algal biomass that is converted to particulate organic matter when } \\
\text { algae die (diatoms) }\end{array}$ & 0.5 & 0.5 & 0.5 \\
\hline ALPOM & $\begin{array}{l}\text { Fraction of algal biomass that is converted to particulate organic matter when } \\
\text { algae die (green) }\end{array}$ & 0.5 & 0.5 & 0.5 \\
\hline ANPR & Algal half saturation constant for ammonium preference (green) & 0.003 & 0.003 & 0.003 \\
\hline ANPR & Algal half saturation constant for ammonium preference (blue-green) & 0.003 & 0.003 & 0.003 \\
\hline O2AR & Oxygen stoichiometry for algal respiration & 1.1 & 1.1 & 1.1 \\
\hline $\mathrm{O} 2 \mathrm{AR}$ & Oxygen stoichiometry for algal respiration & 1.1 & 1.1 & 1.1 \\
\hline O2AR & Oxygen stoichiometry for algal respiration & 1.1 & 1.1 & 1.1 \\
\hline $\mathrm{O} 2 \mathrm{AG}$ & Oxygen stoichiometry for algal primary production & 1.6 & 1.6 & 1.6 \\
\hline $\mathrm{O} 2 \mathrm{AG}$ & Oxygen stoichiometry for algal primary production & 1.6 & 1.6 & 1.6 \\
\hline $\mathrm{O} 2 \mathrm{AG}$ & Oxygen stoichiometry for algal primary production & 1.6 & 1.6 & 1.6 \\
\hline LDOMDK & Labile dissolved organic matter (DOM) decay rate, day ${ }^{-1}$ & 0.1 & 0.12 & 0.04 \\
\hline RDOMDK & Refractory DOM decay rate, day ${ }^{-1}$ & 0.006 & 0.01 & 0.003 \\
\hline LRDDK & Labile to refractory DOM decay rate, day ${ }^{-1}$ & 0.005 & 0.003 & 0.001 \\
\hline LPOMDK & Labile particulate organic matter (POM) decay rate, day ${ }^{-1}$ & 0.05 & 0.1 & 0.05 \\
\hline RPOMDK & Refractory POM decay rate, day ${ }^{-1}$ & 0.003 & 0.002 & 0.003 \\
\hline LRPDK & Labile to refractory POM decay rate, day ${ }^{-1}$ & 0.005 & 0.02 & 0.007 \\
\hline POMS & POM settling rate, $\mathrm{m} \cdot$ day $^{-1}$ & 0.18 & 0.15 & 0.09 \\
\hline ORGP & Stoichiometric equivalent between organic matter and phosphorus & 0.0015 & 0.0025 & 0.0022 \\
\hline ORGN & Stoichiometric equivalent between organic matter and nitrogen & 0.0825 & 0.08 & 0.072 \\
\hline ORGC & Stoichiometric equivalent between organic matter and carbon & 0.45 & 0.45 & 0.45 \\
\hline
\end{tabular}


Table 4. Parameters used for the water-quality algorithms for Lake Carlos, Elk Lake, and Trout Lake.—Continued

$\left[\mathrm{m}^{-1}\right.$, per meter; $\mathrm{g} \cdot \mathrm{m}^{-3}$, grams per cubic meter; day ${ }^{-1}$, per day; $\mathrm{m} \cdot \mathrm{day}^{-1}$, meters per day; $\mathrm{W} \cdot \mathrm{m}^{-2}$, watts per square meter; ${ }^{\circ} \mathrm{C}$, degrees Celsius; $\mathrm{m} \cdot \mathrm{s}^{-1} ; \mathrm{meters}$ per second; $\mathrm{g} \cdot \mathrm{m}^{-2} \cdot$ day $^{-1}$, grams per square meter per day; bold text indicates parameters adjusted from default value]

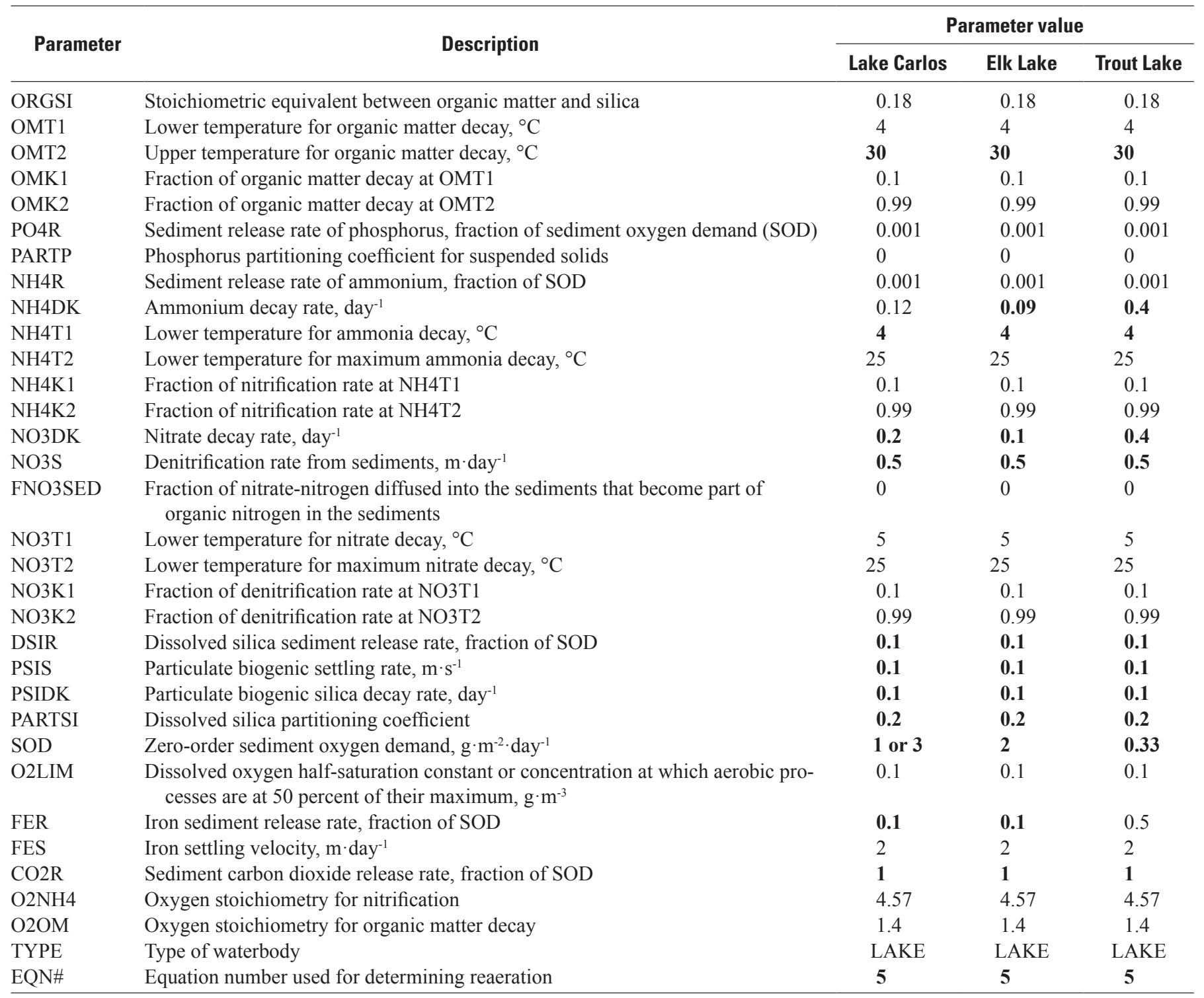

\section{Model Calibration}

The degree of fit between the simulated results and measured lake values was considered during model calibration. The two quantities utilized to evaluate the degree of fit were the absolute mean error (AME) and the root mean square error (RMSE). The AME, computed by equation 1 (for example, see usage in Galloway and others, 2008), is a measure of the average difference between the simulated (simulated) value and the measured value:

$$
A M E=\frac{1}{n} \sum_{i=1}^{n} \mid \text { simulated value }- \text { measured value } \mid
$$

where $n$ is the number of observations. For example, an AME of 1.0 milligram per liter $(\mathrm{mg} / \mathrm{L})$ for DO means that the simulated model value is on average within $1.0 \mathrm{mg} / \mathrm{L}$ of the measured DO value. The RMSE is a slightly different metric in that it indicates the amount of deviation between the simulated value and the measured value. The RMSE, as computed by equation 2 (for example, see usage in Galloway and others, 2008), gives the deviation between the simulated value and the measured value approximately 67 percent of the time: 


$$
R M S E=\sqrt{\frac{1}{n} \sum_{i=1}^{n}(\text { simulated value }- \text { measured value })^{2}}
$$

The degree of fit between the simulated and measured outlet water temperature and the water-surface elevation was only considered during the initial calibration for each of the lake models. By calibrating to outlet water temperature and watersurface elevation first, the subsequent water-quality calibration was easier given that the effects such as wind stress, inflow water temperature, meteorological effects, and the amount of flow in and out of the lake had already been taken into account. The water-quality calibration for DO, nutrients, water temperature (hypolimnion, epilimnion), and algae followed, using the AME and RMSE metrics. In a few cases, the measured lake water-quality value was outside the simulation time period by as much as 1 day; in such cases, the water-quality measurement was compared to the closest simulated value.

\section{Water Balance}

The first step in the calibration process for all three lake models was the water balance. Before the temperature and water-quality calibration could proceed, the differences between the simulated and measured water-surface elevations were rectified. A water balance was considered complete when the AME and RMSE quantities were less than $0.01 \mathrm{~m}$ for the simulated water-surface elevation.

\section{Lake Carlos}

The initial attempt to achieve a water balance for Lake Carlos used the two gaged tributaries, the Lake Darling outlet and Lake Le Homme Dieu outlet (table 1), as the sole inflows for the calibration period of April 20, 2010, to November 10, 2010; however, the simulated water-surface elevation was below the measured water-surface elevation, which indicates additional sources of water to the lake including ungaged tributaries and groundwater. To account for this unaccounted inflow, a distributed tributary flow was added to all segments equally.

This distributed tributary flow can be positive or negative; large positive values were found to correlate with large precipitation events, whereas negative values usually were during the driest portions of the calibration. A comparison between the simulated and measured water-surface elevations for Lake Carlos is shown in figure 11.

\section{Elk Lake}

The initial attempt to achieve a water balance for Elk Lake included the four ungaged tributaries as the inflows for the calibration period of April 26, 2011, to November 8, 2011. Similar to Lake Carlos, the simulated water-surface elevation was below the measured water-surface elevation. This revealed the existence of other ungaged inflows, or groundwater flow, into or out of the lake. Also, the method for apportioning the inflows underrepresented the true inflows, given that the CE-QUAL-W2 model accounts for evapotranspiration from the lake. To account for this unaccounted inflow, a distributed tributary flow was added to all segments equally. A comparison between the simulated and measured water-surface elevations for Elk Lake is shown in figure 12.

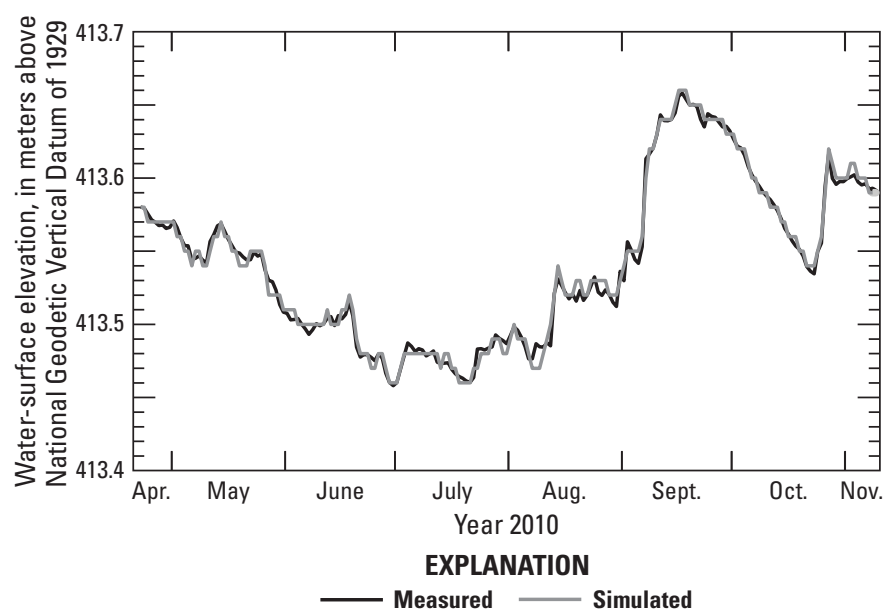

Figure 11. Simulated and measured water-surface elevations for Lake Carlos, April 20 to November 10, 2010.

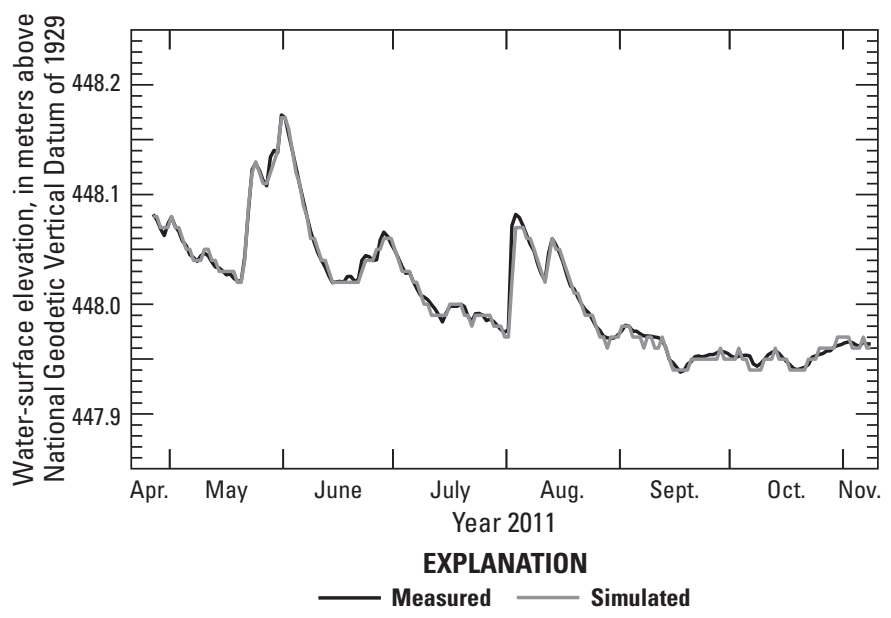

Figure 12. Simulated and measured water-surface elevations for Elk Lake, April 26 to November 8, 2011.

\section{Trout Lake}

The initial attempt to achieve a water balance for Trout Lake included the two ungaged tributaries as the inflows for the calibration period of April 28, 2010, to October 21, 2010. Similar to Lake Carlos and Elk Lake, the simulated water-surface elevation was below the measured water-surface elevation. Following the same approach as for Lake Carlos and Elk Lake, a distributed tributary flow was added to all segments equally. A comparison between the simulated and measured water-surface elevations for Trout Lake is shown in figure 13. 


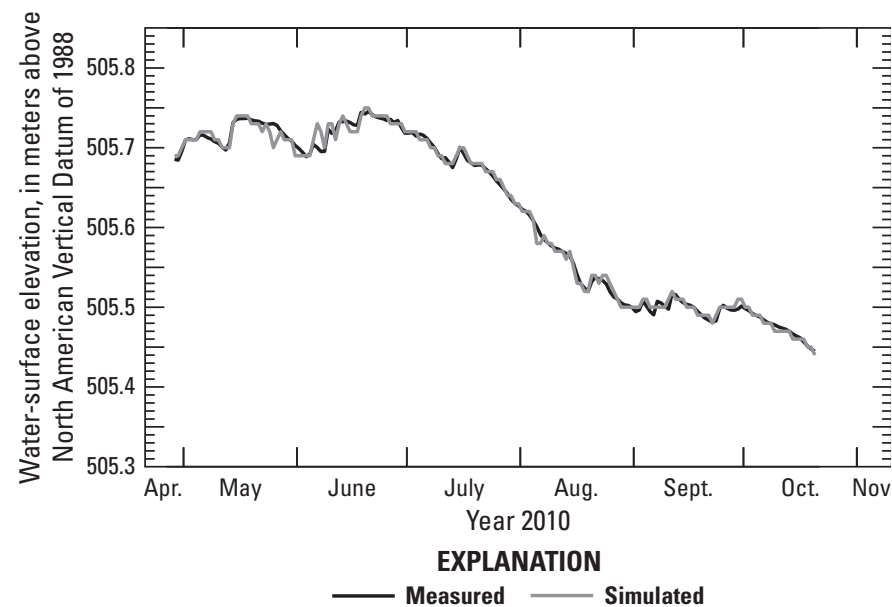

Figure 13. Simulated and measured water-surface elevations for Trout Lake, April 28 to October 21, 2010.

\section{Temperature}

A critical calibration step is water-temperature calibration because of the effect of temperature on water density. Boundary conditions that affect water temperature include sediment temperature, initial lake-water temperature, and inflow water temperature. Meteorological effects include air temperature, wind velocity, wind direction, and solar radiation. Because solar radiation was not directly available for any of the lake models, an internal calculation within the model was made based on the amount of cloud cover and the latitude/longitude. Wind effects can be further augmented by the wind sheltering coefficient, controlled via a separate input file, which takes into account the effects of boundary factors such as topography and shoreline tree cover on wind mixing. Several hydraulic parameters also affect water temperature. For example, the amount of reradiated heat back to the water column from solar radiation that penetrates the entire water column is controlled by the TSEDF parameter (table 4), a hydraulic coefficient. For the three lake models, the CE-QUAL-W2 default value of 100 percent was used. Another set of critical parameters includes the extinction coefficients, which specify the water absorption of light and other ancillary extinction coefficients for organic matter, suspended sediment, and algae (table 4).

\section{Lake Carlos}

The epilimnion (2-m depth) and hypolimnion (41-m depth) at Kecks Point (fig. 14; table 5) were the initial temperature calibration targets. A challenge for the temperature calibration was the tradeoff between the degree of fit, based on AME and RMSE quantities, for the epilimnion and the hypolimnion at Kecks Point. Without adjusting the initial lake water temperature and sediment temperature to unrealistically low values or adjusting the default model parameters for the hydrodynamics, settling at close to $1.0^{\circ} \mathrm{C}$ for the AME and RMSE in the hypolimnion seemed reasonable. The AME and
RMSE quantities of $0.48{ }^{\circ} \mathrm{C}$ and $0.67^{\circ} \mathrm{C}$, respectively, for the epilimnion were comparatively lower than $1.0^{\circ} \mathrm{C}$ and followed the measured temporal variations throughout the year (fig. 14). The correlation did deviate with warmer simulated epilimnion temperatures throughout most of the summer months from late June through August. The primary cause of the deviation was the increased wind speed coefficient during this period, increasing from 64 to 70 percent during the rest of the year to 80 percent in the summer months. The wind speed coefficient controls the amount of wind energy transferred to the lake, with lower coefficients caused by shifts in primary wind directions during the year and differences in terrain between the meteorological station and the lake itself. Slightly better AME and RMSE quantities were achieved with a lower wind speed coefficient during the summer months; however, this had a dramatic effect on the DO correlation.

A secondary calibration target was the outlet water temperature measured at the Long Prairie River. However, because the site is approximately $100 \mathrm{~m}$ downstream from the lake, the calibration target was given a lower priority and no specific adjustments to achieve better AME and RMSE values were made for this location (table 5).

Simulated water temperature in Lake Carlos also was compared to lake profile data at Kecks Point, available from continuous thermistor profiles or point measurements by MPCA or USGS personnel. A total of 15 dates are shown in figure 15. Low AME (at or less than $1.0^{\circ} \mathrm{C}$ ) and RMSE values (at or less than $1.2^{\circ} \mathrm{C}$ ) for most dates provided confidence in the model's ability to predict water temperature.

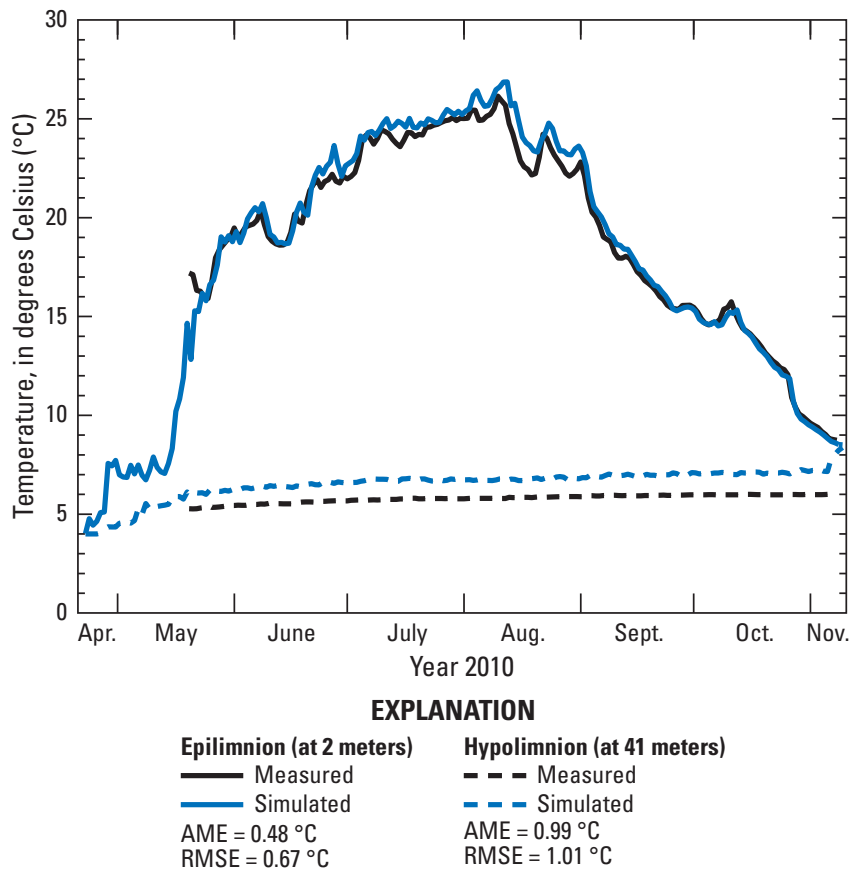

Figure 14. Simulated and measured water temperature for the epilimnion and hypolimnion at Kecks Point for Lake Carlos, April 20, 2010, to November 10, 2010, with quantities of absolute mean error (AME) and root mean square error (RMSE). 


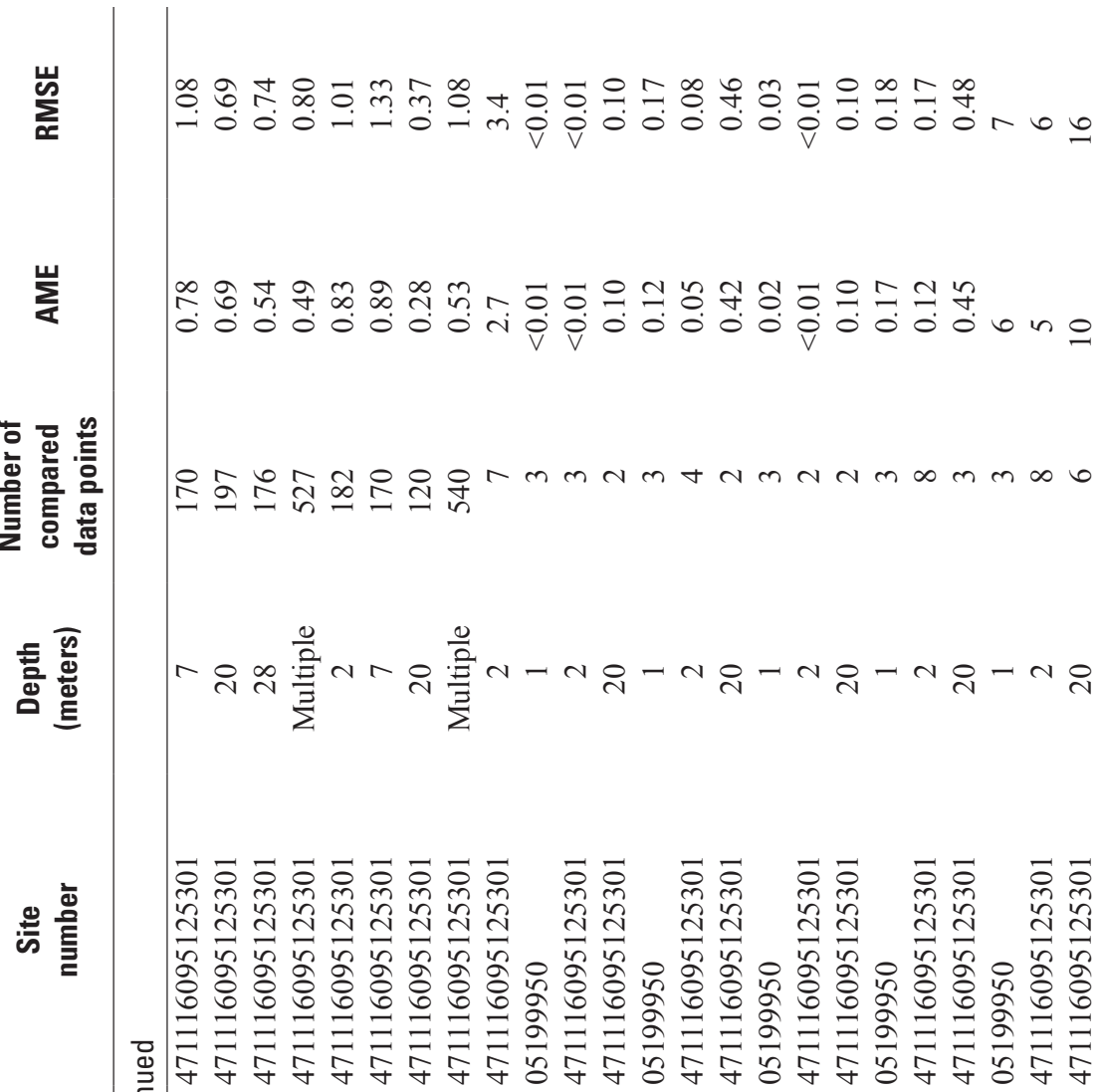

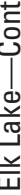

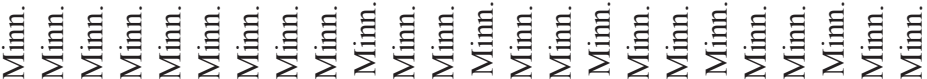

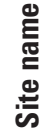

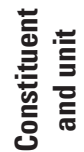

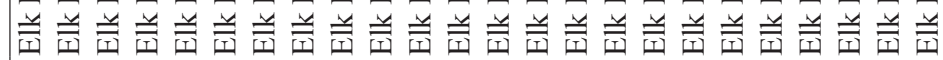

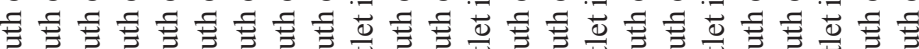
o

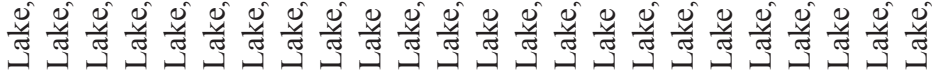

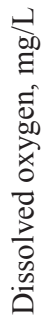

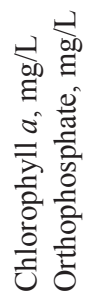

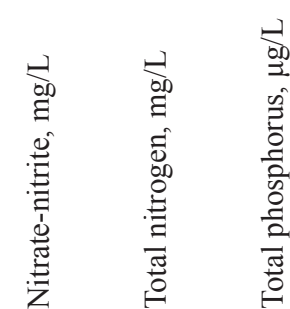

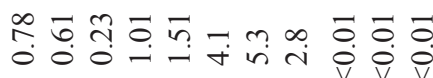

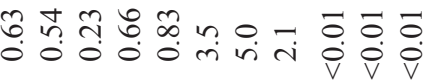

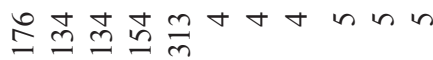

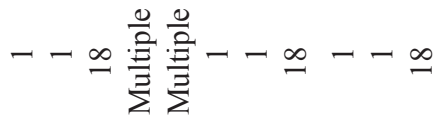

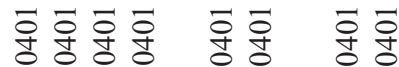

응 $\cong$

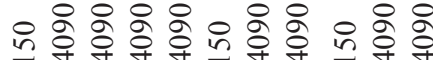

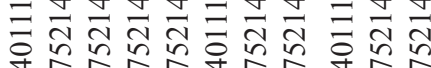

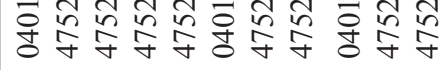

产

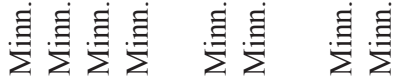

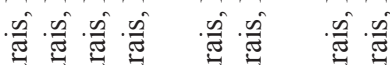

$\sum_{i}^{\pi} \sum_{i}^{\pi} \sum_{i}^{\pi} \sum_{i}^{\pi} \sum_{i}^{\pi} \sum^{\pi}$

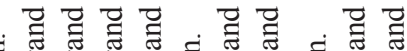

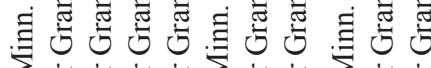

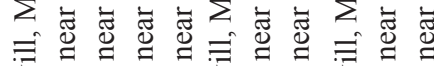

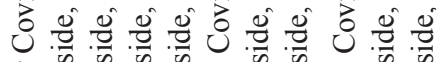

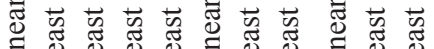

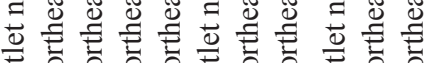

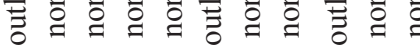

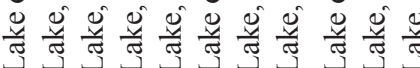

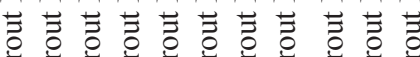

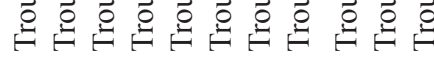

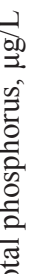

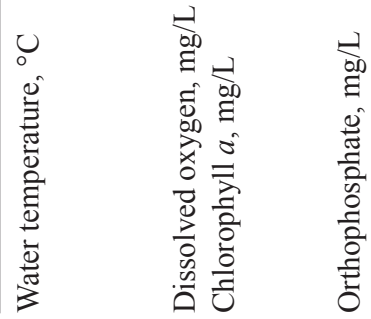




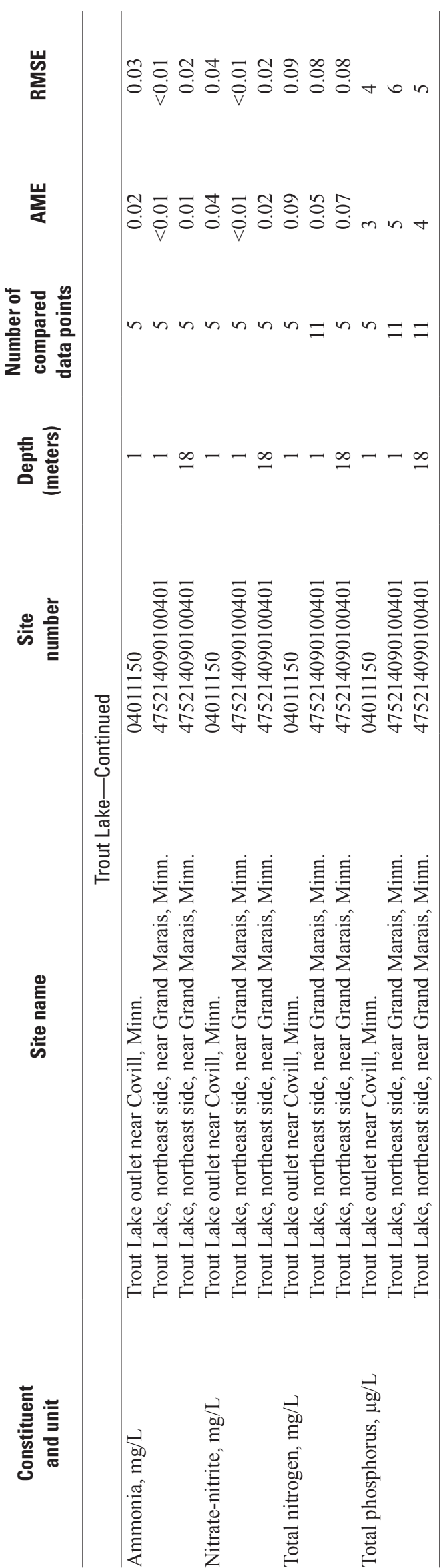

The model also approximated the location of the thermocline. In the early part of 2010 (through the end of June), the slope of the thermocline was shallower in the simulated temperatures compared to the measured temperatures. However, as the year progressed, the difference between the measured and simulated temperature profile was less, and the thermocline slope was closely approximated. The model does predict, by about 10 days early, the lake overturn as shown in the fully mixed, simulated profile on the final simulated date (November 9, 2010).

\section{Elk Lake}

In Elk Lake, the principal temperature calibration targets were two locations in the epilimnion (2- and 7-m depths, respectively) and two locations in the hypolimnion (20- and 28-m depths, respectively) at the south basin hole (fig. 16; table 5). Three of the four depths had AME and RMSE values below or equal to $0.80^{\circ} \mathrm{C}$. The shallowest location (2-m depth) had AME and RMSE values of $0.65{ }^{\circ} \mathrm{C}$ and $0.80^{\circ} \mathrm{C}$, respectively. The two hypolimnion locations also had low AME and RMSE values. At $20 \mathrm{~m}$ below the surface, the AME and RMSE values were both $0.69^{\circ} \mathrm{C}$. At $28 \mathrm{~m}$ below the surface, the AME and RMSE values were $0.54^{\circ} \mathrm{C}$ and $0.74{ }^{\circ} \mathrm{C}$, respectively. The AME and RMSE values at the metalimnion depth $\left(7-\mathrm{m}\right.$ depth) were $0.78^{\circ} \mathrm{C}$ and $1.08^{\circ} \mathrm{C}$, respectively. The cause of the slightly higher AME and RMSE for the 7-m depth, or lower correlation (fig. 16), likely was because of the deepening of the thermocline through this location over the course of the year. Unlike at Lake Carlos, no major offsets in the slope of the thermocline are indicated for Elk Lake during one period of the year over another. A consistent wind sheltering coefficient of 67 percent was applied during most of the year (simulation dates after June 2). For simulation dates before June 2, the wind sheltering coefficient was set to 50 percent; this alteration was because of the availability and use of wind measurements at the lake after this date as opposed to use of data from the more distant Park Rapids meteorological station before this date.

A secondary calibration target was the outlet water temperature as measured at the Elk Lake outlet. However, for the same reasons as the outlet location for Lake Carlos, this calibration target was given a lower priority and no specific adjustments to achieve better AME and RMSE values were made for this location (table 5).

Simulated water temperature in Elk Lake also was compared to lake profile data at the south basin hole, available from continuous thermistor profiles or point measurements by MPCA or USGS personnel. A total of 15 dates are shown in figure 17. As mentioned in the Lake Carlos section, low AME and RMSE quantities provide additional confidence in the model's ability to predict water temperature. For Elk Lake, the model consistently attained AME and RMSE values at or less than $1.0^{\circ} \mathrm{C}$ for all but two dates, with several values less than $0.5^{\circ} \mathrm{C}$. In addition, the location and slope of the simulated thermocline matched the measured thermocline. Similar to the 

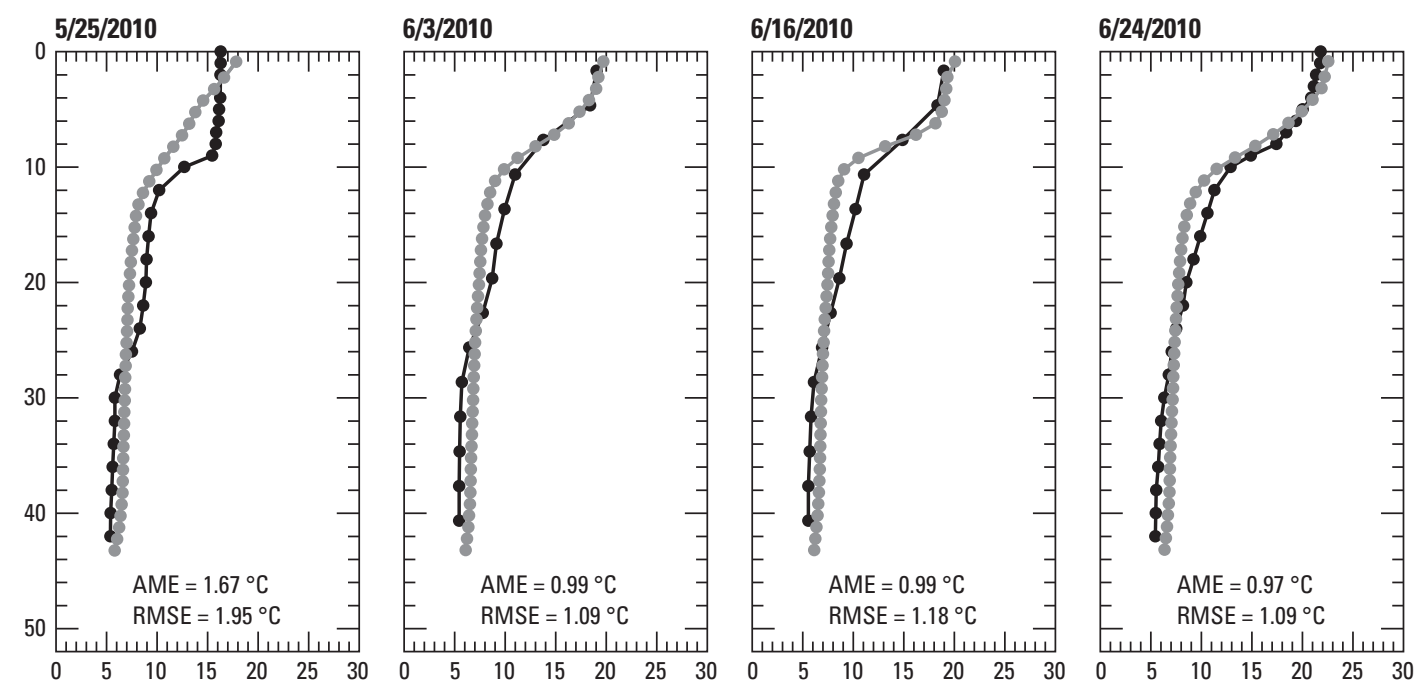

$7 / 3 / 2010$

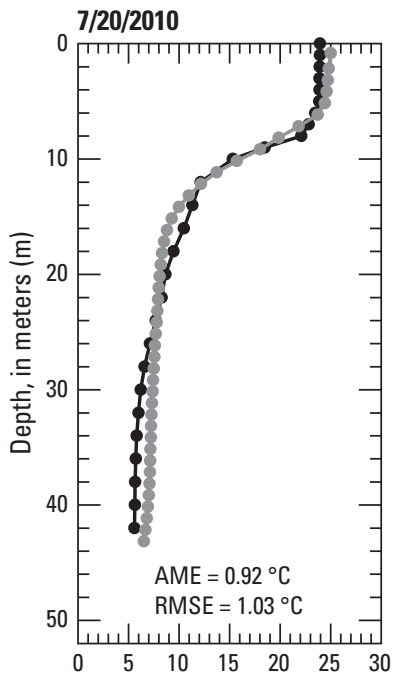

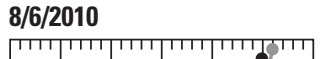
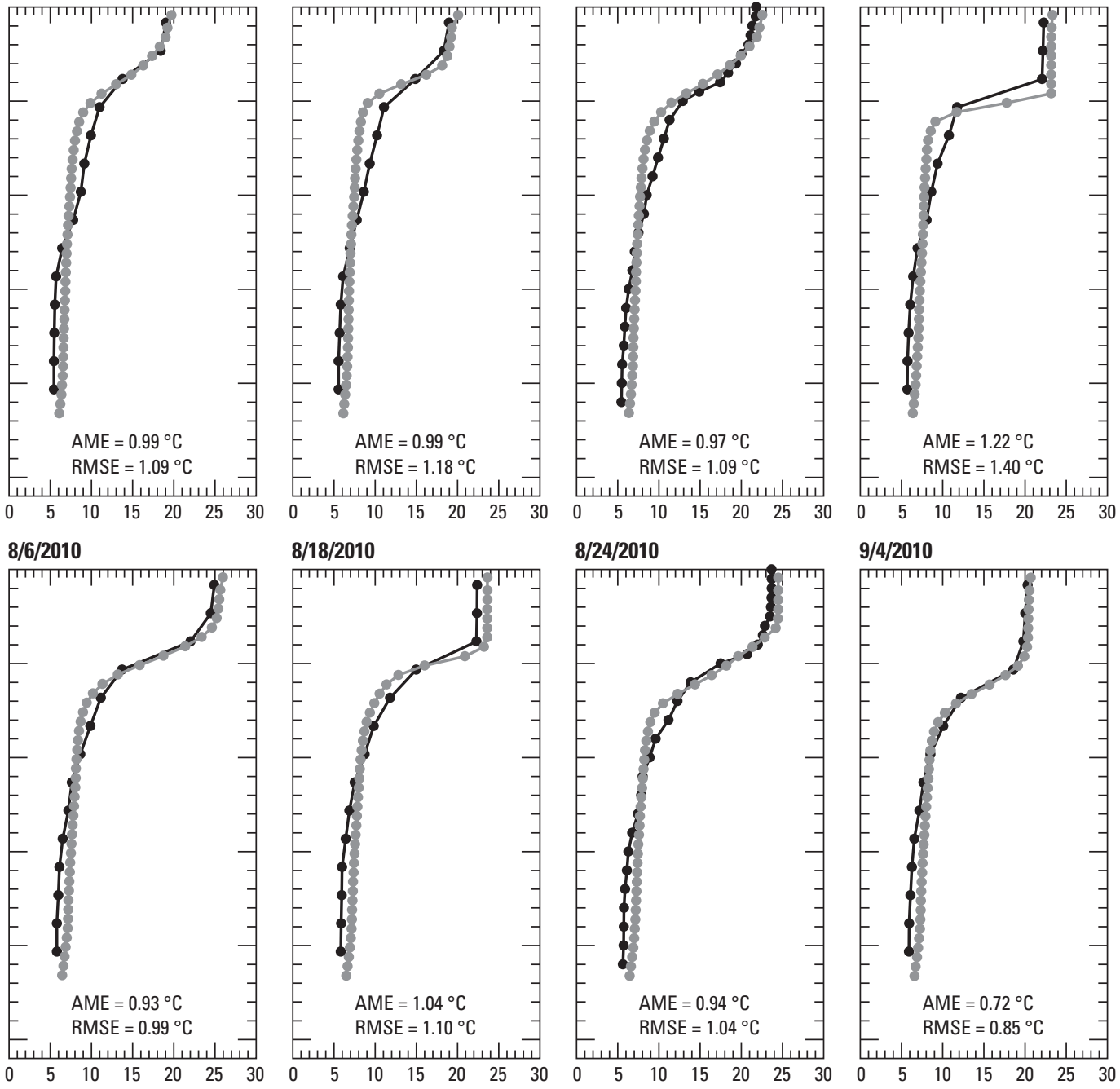

9/4/2010
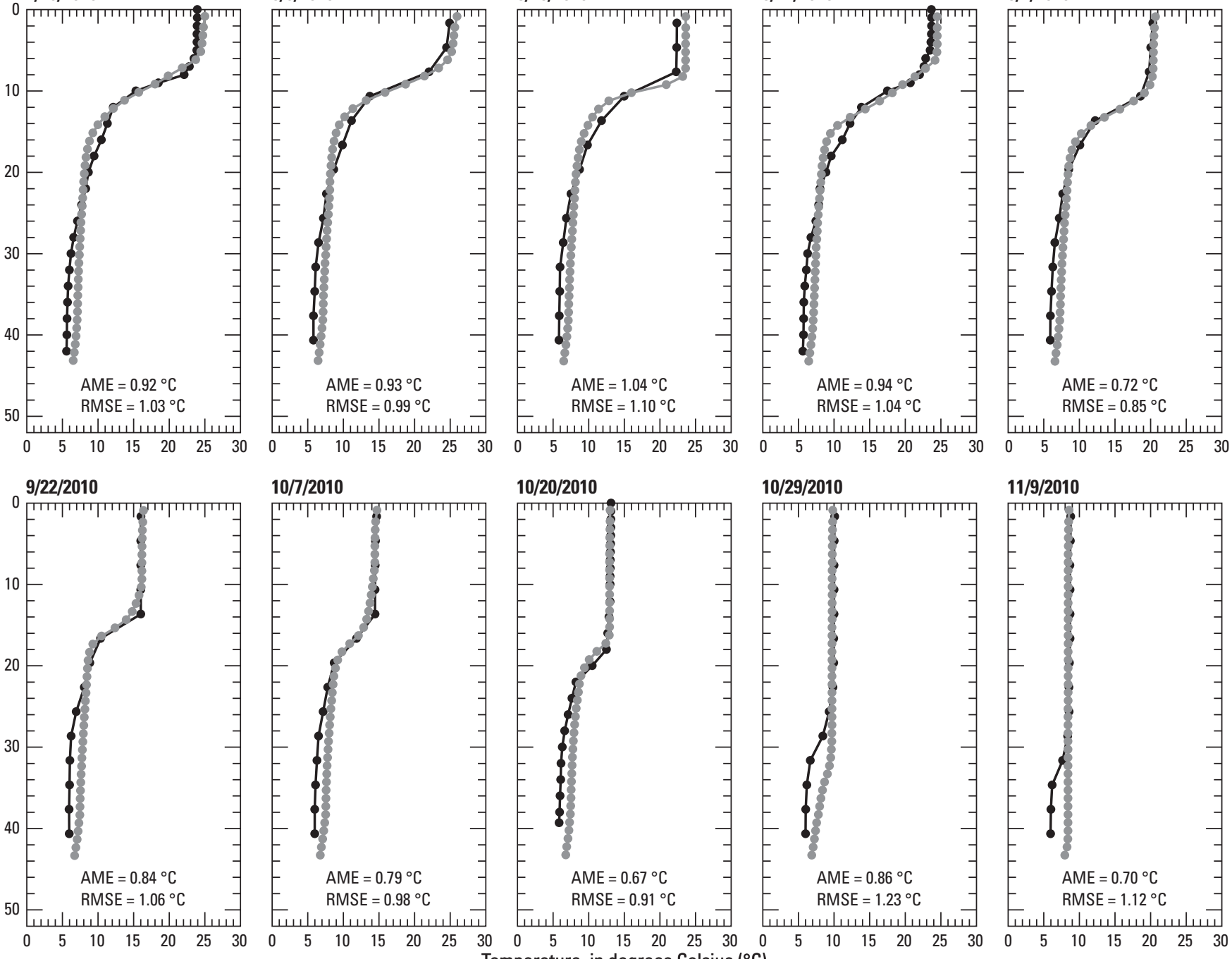

$11 / 9 / 2010$
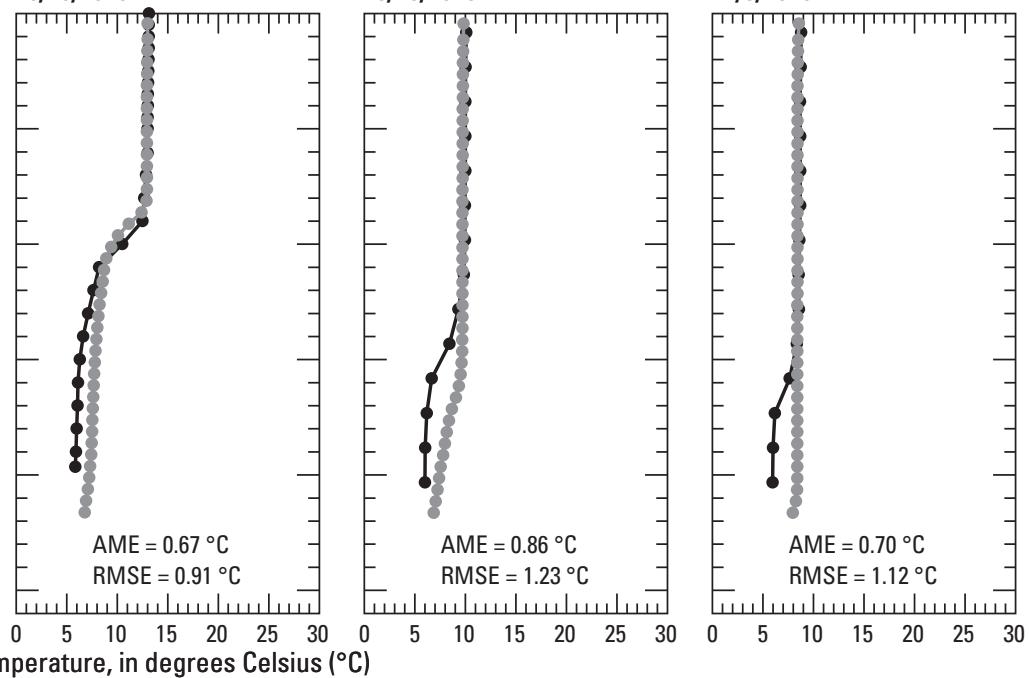

EXPLANATION

$\rightarrow$ Measured $\longrightarrow$ Simulated

Figure 15. Simulated and measured water temperature at Kecks Point in Lake Carlos for 15 dates in 2010, with quantities of absolute mean error (AME) and root mean square error (RMSE). 

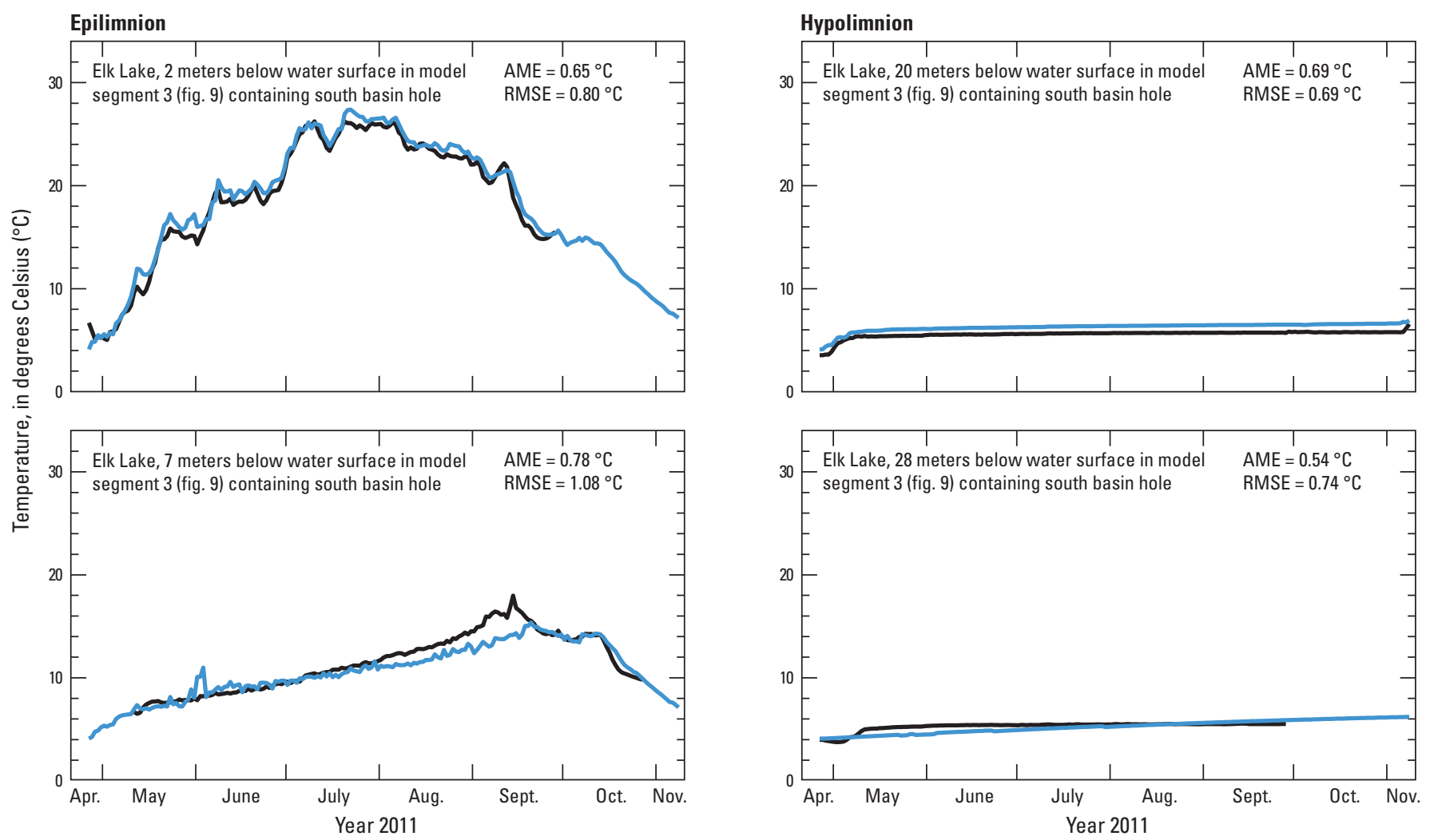

EXPLANATION

Measured $\longrightarrow$ Simulated

Figure 16. Simulated and measured water temperature for the epilimnion and hypolimnion at the south basin hole in Elk Lake, April 26 , 2011, to November 8, 2011, with quantities of absolute mean error (AME) and root mean square error (RMSE).

model for Lake Carlos, the model for Elk Lake did seem to predict lake thermal overturn early by about $7-10$ days.

\section{Trout Lake}

In Trout Lake, the principal temperature calibration targets were the epilimnion (1-m depth) and hypolimnion (18-m depth) at the north basin hole (fig. 18; table 5). The epilimnion had low AME and RMSE quantities of $0.54{ }^{\circ} \mathrm{C}$ and $0.61{ }^{\circ} \mathrm{C}$, respectively. The hypolimnion location had even lower AME and RMSE quantities of $0.23{ }^{\circ} \mathrm{C}$. The low AME and RMSE quantities for the epilimnion were somewhat surprising given the potential volatility of such a shallow measurement at $1 \mathrm{~m}$ because of fluctuations from air temperature shifts, wind effects, and solar radiation. Simulated temperatures were lower than the measured temperatures in the epilimnion after September 1; however, the difference between the measured and simulated values did not go beyond $1.0^{\circ} \mathrm{C}$. The only shift in the wind sheltering coefficient was from 100 percent to 60 percent after September 15 to simulate leaf off.

A secondary calibration target was the outlet water temperature as measured at the Trout Lake outlet. However, for the same reasons as the outlet location for Lake Carlos and Elk Lake, this was given a lower priority and no specific adjustments to achieve better AME and RMSE values were made for this location. Simulated water temperature in Trout Lake also was compared to lake profile data at the north basin hole, available from continuous thermistor profiles or point measurements by MPCA or USGS personnel. Simulated water temperature and lake profile data are shown for a total of 14 dates in figure 19. For Trout Lake, the model consistently attained AME values at or below $1.0^{\circ} \mathrm{C}$, with several values less than $0.6^{\circ} \mathrm{C}$, and RMSE values in the acceptable range at or below $1.3{ }^{\circ} \mathrm{C}$. The simulated thermocline generally was a little deeper than the measured thermocline, but generally matched the slope. The final measurement date of October 21 was a little early for lake overturn, so it was difficult to evaluate whether or not the same issue of early predicted lake overturn existed for Trout Lake as with the other two lakes.

\section{Dissolved Oxygen}

Coldwater fish species and other aquatic organisms cannot survive without adequate DO. Accurately simulating DO is critical in determining the size of summer habitat refugia for coldwater fish species because their thermal requirements confine them below the epilimnion where they are vulnerable to mass die offs because of a lack of DO. For example, 

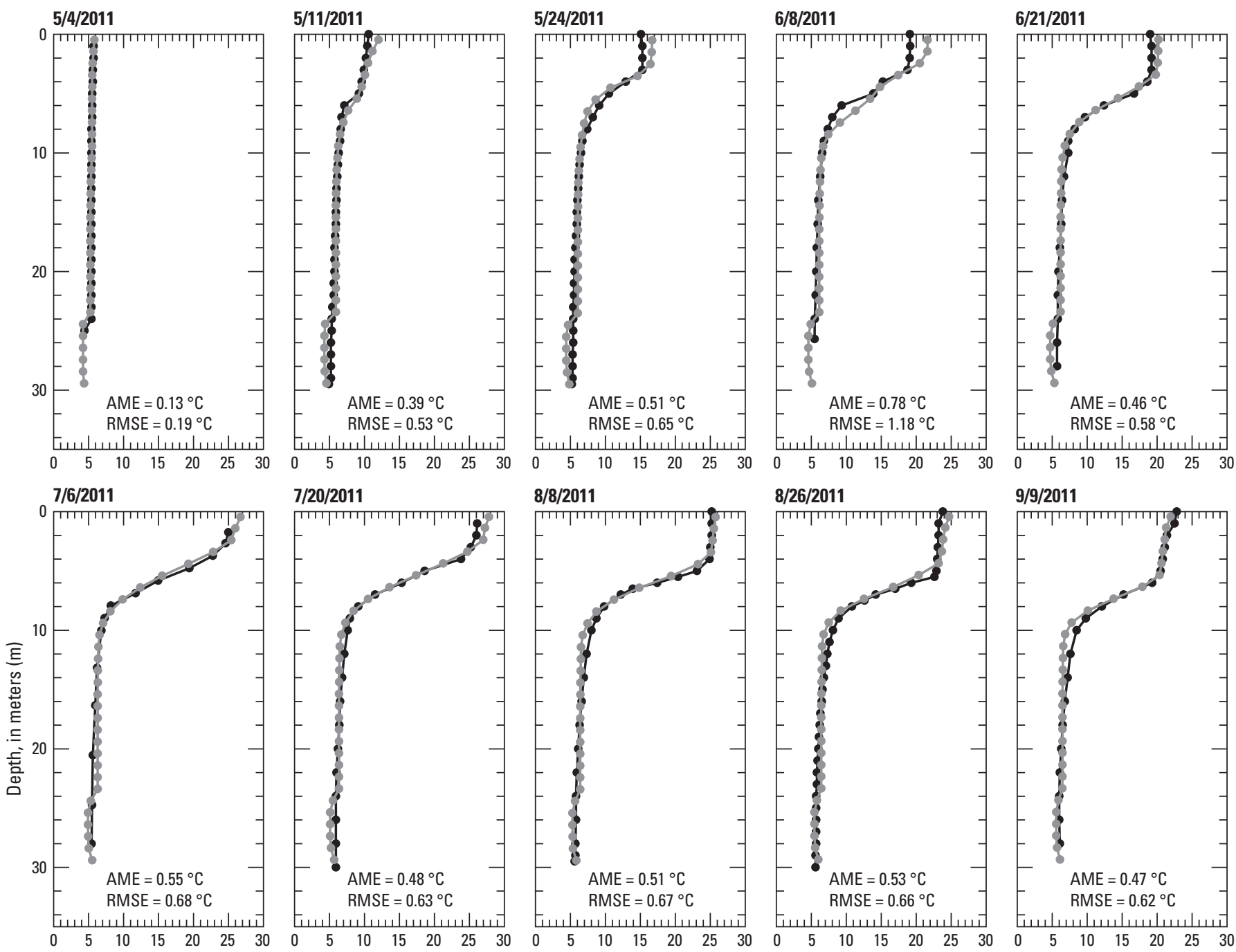

9/9/2011
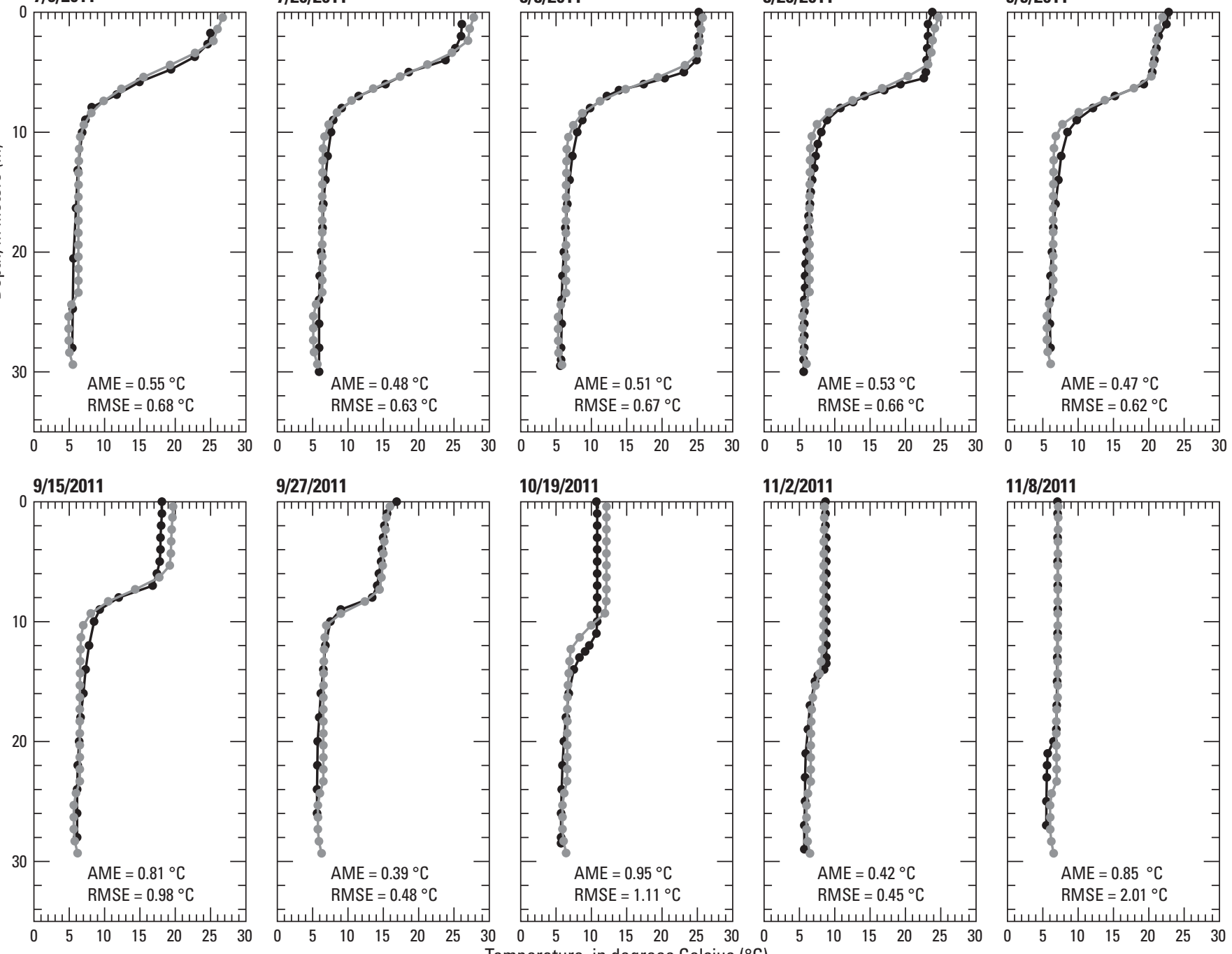

10/19/2011

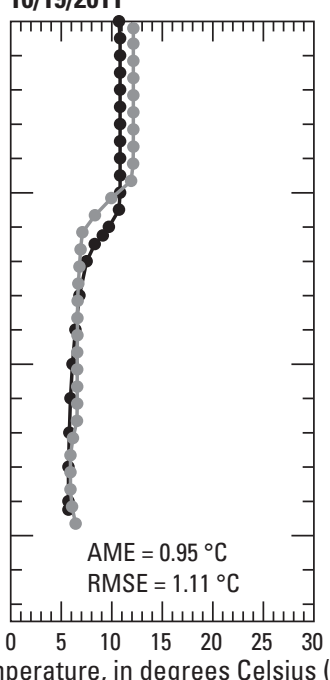

$11 / 2 / 2011$

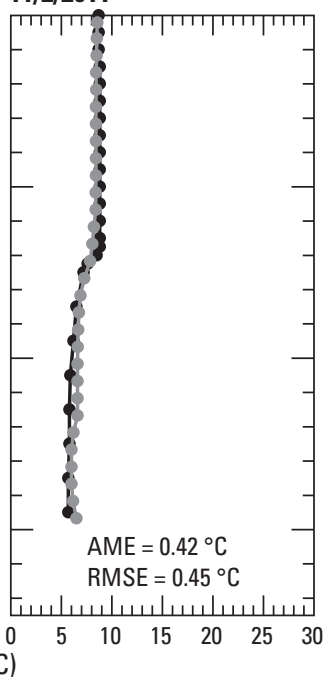

$11 / 8 / 2011$

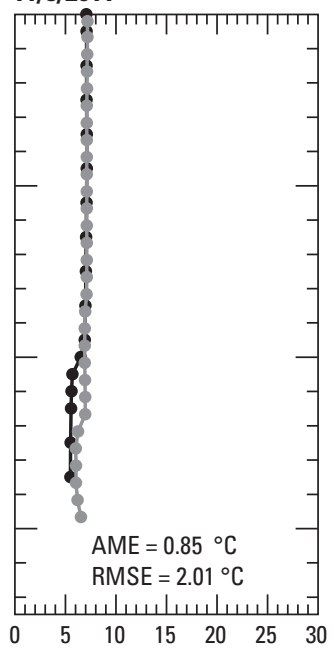

\section{EXPLANATION}

$\rightarrow$ Measured $\longrightarrow$ Simulated

Figure 17. Simulated and measured water temperature at the south basin hole in Elk Lake for 15 dates in 2011, with quantities of absolute mean error (AME) and root mean square error (RMSE). 


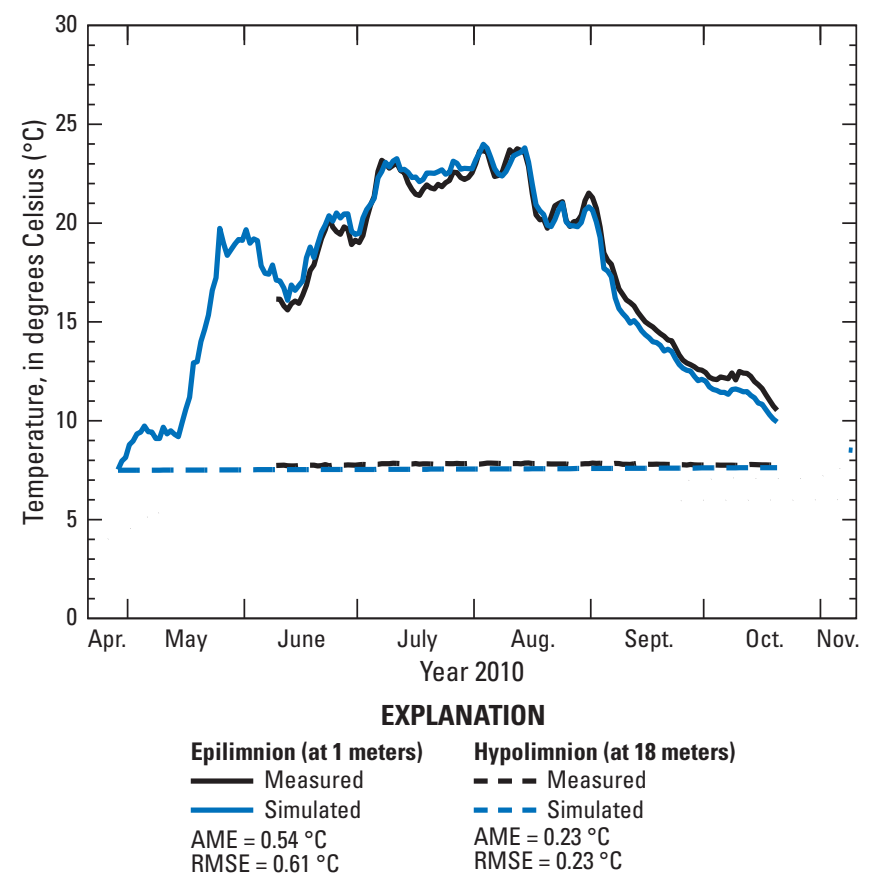

Figure 18. Simulated and measured water temperature for the epilimnion and hypolimnion at the north basin hole in Trout Lake, April 28, 2010, to October 21, 2010, with quantities of absolute mean error (AME) and root mean square error (RMSE).

Jacobson and others (2008) evaluated the lethal oxythermal niche boundary for ciscoes in several Minnesota lakes and found that lethal temperatures were progressively less for lower lethal DO concentrations.

Within the CE-QUAL-W2 model, many sources and sinks are available for DO, which makes DO likely the most complicated constituent to model. Sources include inflows (all sources), atmospheric exchange across the lake surface, and algal photosynthesis (Cole and Wells, 2008). Sinks include the decay in the water column and lake sediments of dissolved organic matter (labile and refractory), particulate organic matter (labile and refractory), and sediment decay itself. Other simulated sinks include algal respiration, ammonia and nitrite nitrification, and exchange back to the atmosphere and into sediments. The values used for these parameters are listed in table 4 . With such complex interactions, especially when simultaneously trying to dynamically model algal communities, several hundred iterations were required for each of the final lake CE-QUAL-W2 models.

Overall, the model captured the trajectories of DO concentrations at multiple depths over time. This indicates that the model was accurately simulating the underlying metabolic processes in each lake. Specific examples of the model capabilities presented in the following subsections include comparisons between simulated and measured vertical profile data for metalimnetic oxygen minimum for Lake Carlos and midwater column oxygen maximum for Elk Lake. Both cases illustrate that the internal trophic dynamics in these deep, coldwater lakes are substantial factors affecting much of the observed biogeochemistry.

\section{Lake Carlos}

For the DO calibration of the Lake Carlos model, the principal calibration targets were the lake profile data from Kecks Point, available from biweekly point measurements collected by MPCA or USGS personnel. Generally, DO measurements were recorded for each meter below water surface, although some gaps were as large as $5 \mathrm{~m}$, specifically in the hypolimnion where DO changes were less drastic. Simulated and measured DO concentrations are shown for a total of 11 dates in figure 20. Overall, the simulated DO concentrations tracked the measured concentrations from Kecks Point. Generally, where the greatest change in DO occurred, the simulated concentrations matched both the depth and slope of the measured concentrations. For example, the negative DO gradient between 5 and $10 \mathrm{~m}$ on June 24, 2010, and July 20, 2010, matched reasonably well but had higher AME and RMSE values (greater than $1.0 \mathrm{mg} / \mathrm{L}$ ) likely because of the mismatch in the depleted DO concentrations in the simulated shallow epilimnion and the enriched DO concentrations in the simulated hypolimnion. For both dates, the simulated DO concentrations were overestimated compared to measured DO concentrations below $25 \mathrm{~m}$ of depth as DO depletion appeared to occur much faster than was simulated. However, as the year progressed, the differences between the simulated and measured DO concentrations were less variable in the epilimnion, hypolimnion, and the transition between the high and low DO zones. For example, the model predicted the metalimnetic oxygen minimum in August. This indicates an accurate simulation of the oxygen demand associated with algal carbon decomposition below the photic zone. The AME quantities were consistently less than or equal to $1.0 \mathrm{mg} / \mathrm{L}$ for almost all dates, with slightly higher RMSE quantities (fig. 20). The only date for which AME and RMSE quantities were considerably large was the final observation on November 9, 2010, when the DO was more fully mixed.

A complex interaction between different processes has a strong effect on the DO concentrations in a lake. The decay rates of the different organic matter pools, such as parameters that control the labile, refractory, and the labile-to-refractory dissolved oxygen matter decay rates (parameters LDOMDK, RDOMDK, and LRDDK, respectively, in table 4), were reasonably high compared to rates for Trout Lake but similar to rates for Elk Lake. Decay rates have the strongest effect on the DO concentrations in the hypolimnion. Sediment oxygen demand (parameter SOD, table 4) also was high for Lake Carlos, set at 1 or $3 \mathrm{mg} / \mathrm{L}$, which can greatly alter the DO profiles in the entire lake. The nitrate decay rate (parameter NO3DK, table 4) was set to 0.2 per day which is similar to the rates for the other two lakes but generally higher than rates used in other CE-QUAL-W2 models (Green and others, 2003; Sullivan and Rounds, 2004; Galloway and Green, 2006; Galloway and others, 2008; Sullivan and others, 2011). 

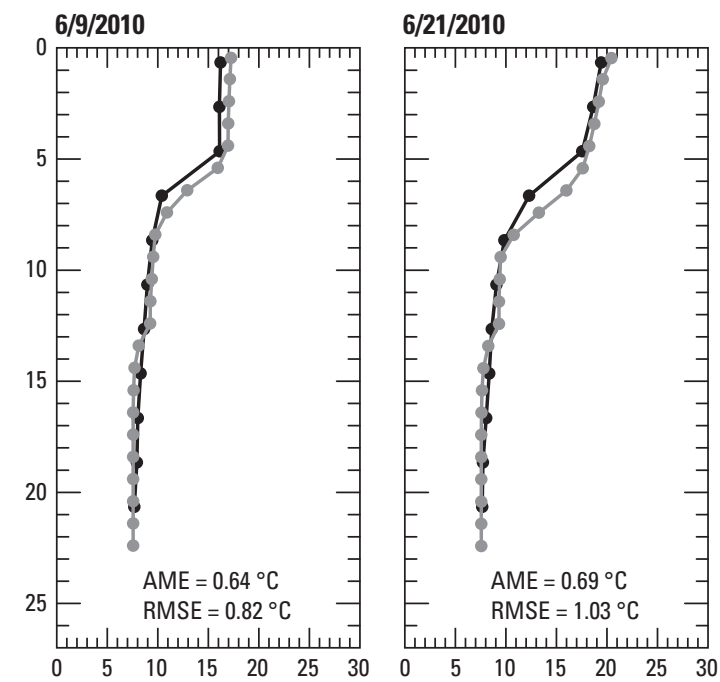

7/1/2010

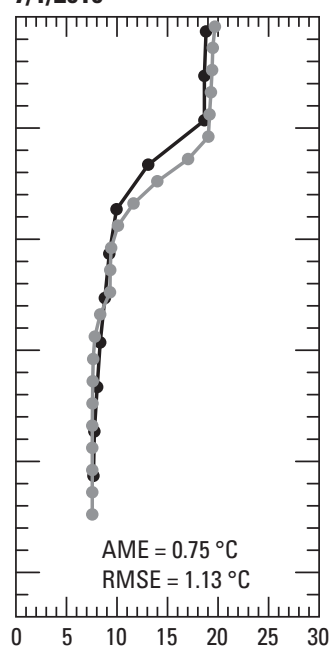

$7 / 30 / 2010$
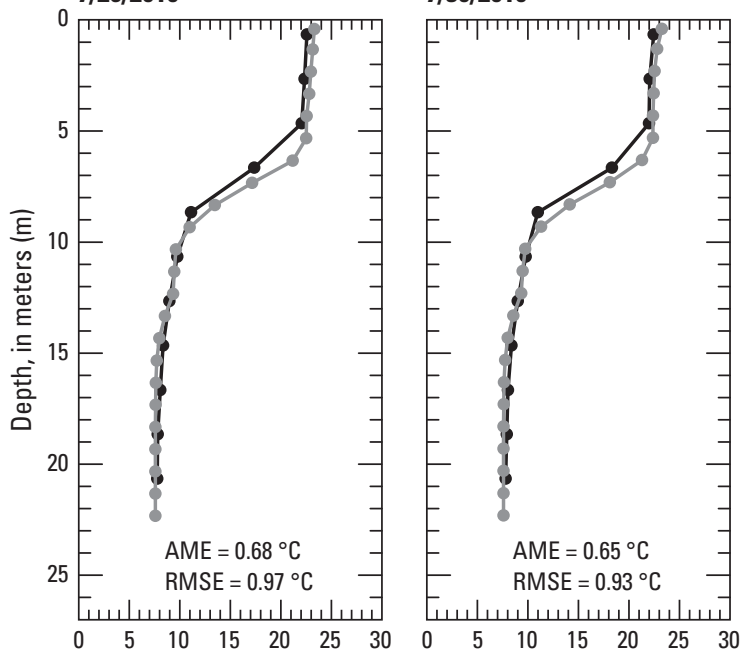

$8 / 12 / 2010$
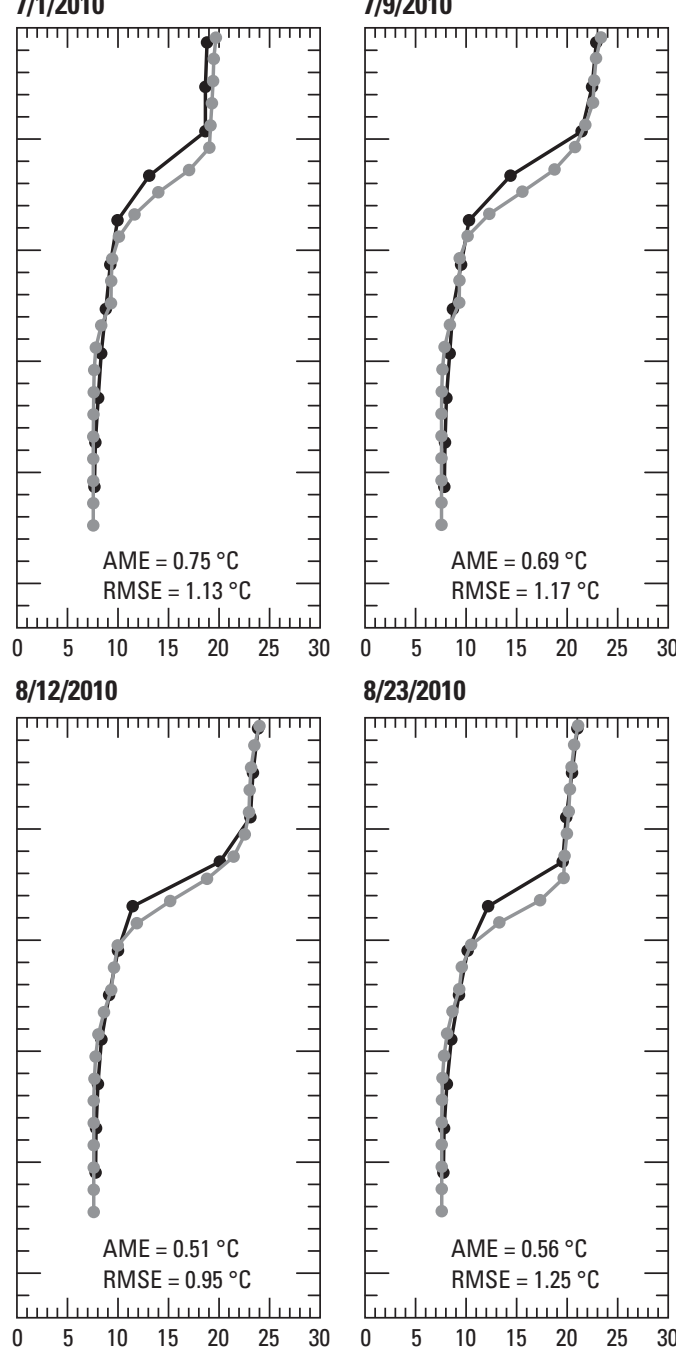

$8 / 23 / 2010$
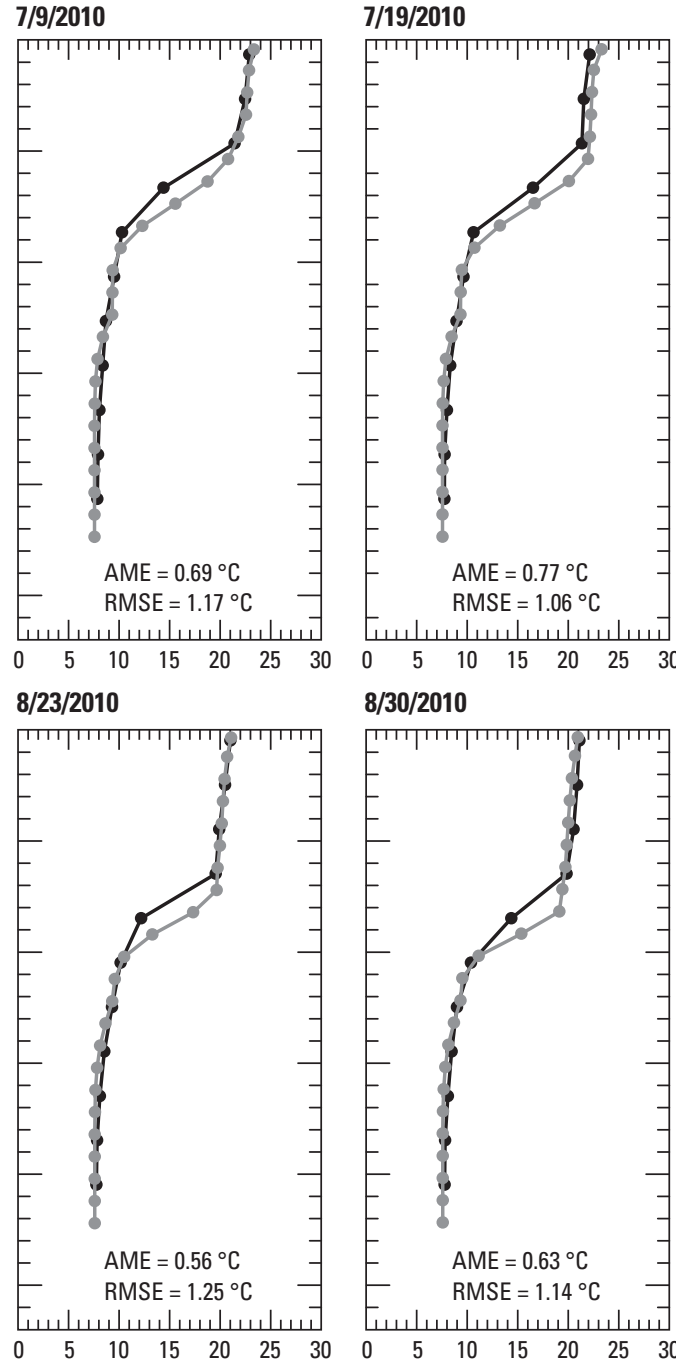

8/30/2010

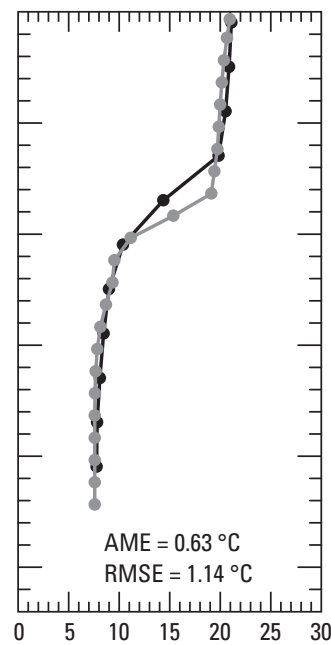

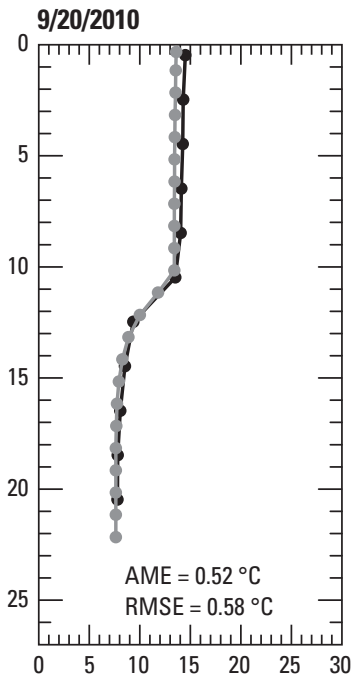

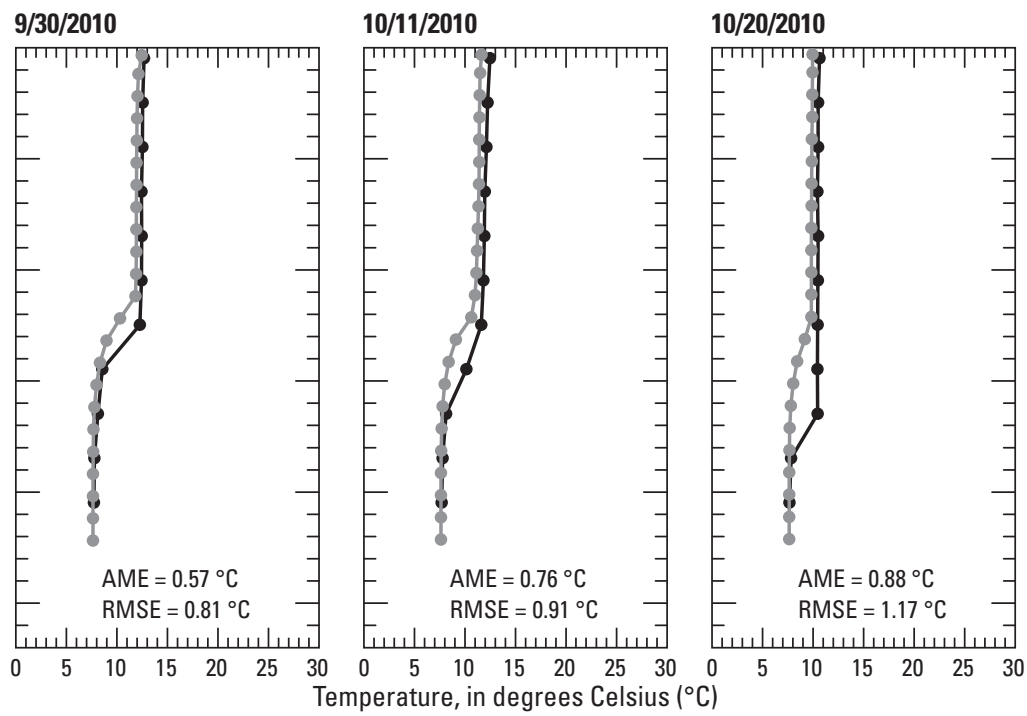

EXPLANATION

$\longrightarrow$ Measured $\multimap-$ Simulated

Figure 19. Simulated and measured water temperature at the north basin hole in Trout Lake for 14 dates in 2010, with quantities of absolute mean error (AME) and root mean square error (RMSE). 

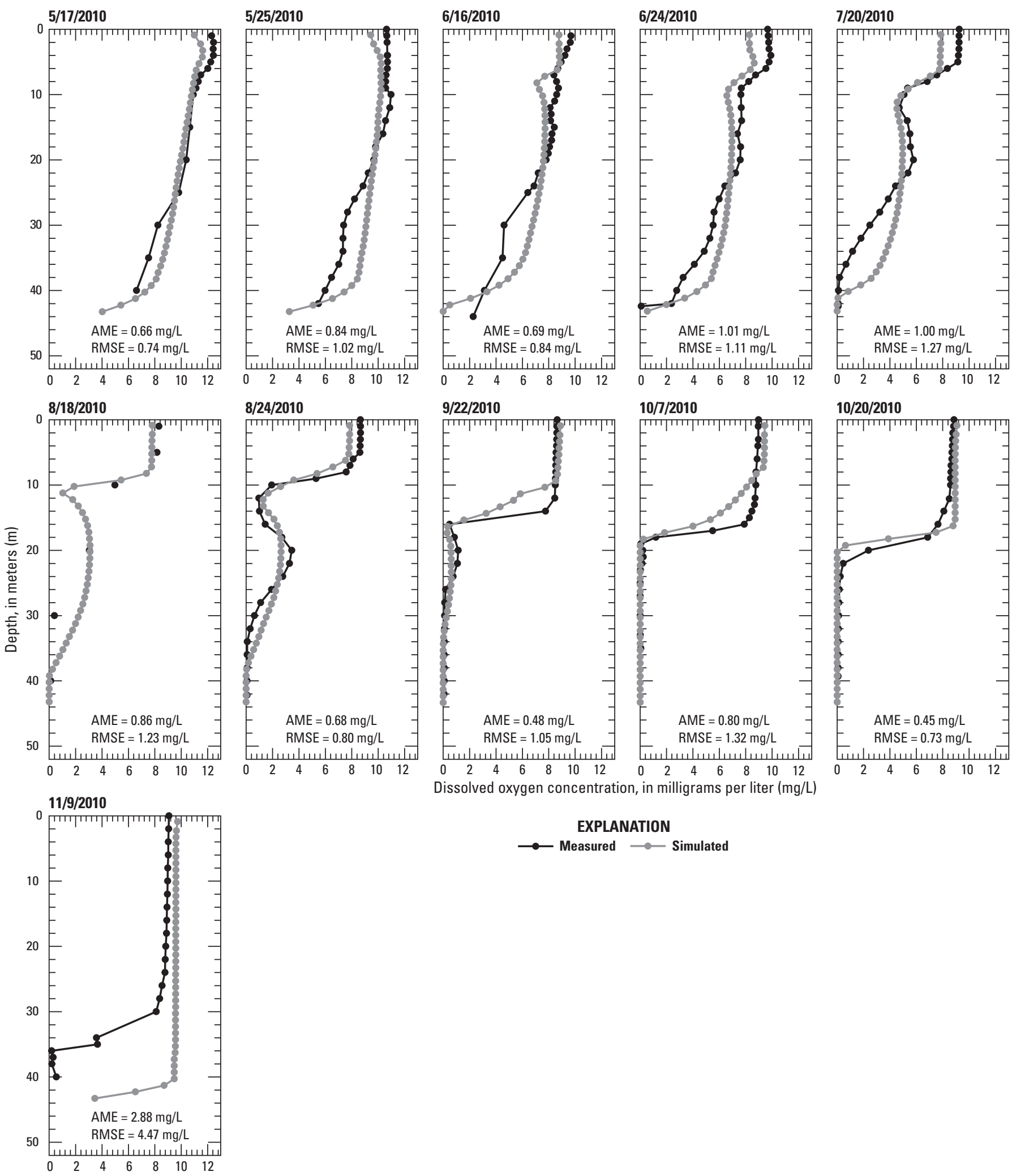

EXPLANATION

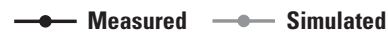

Dissolved oxygen concentration, in milligrams per liter ( $\mathrm{mg} / \mathrm{L})$

Figure 20. Simulated and measured dissolved oxygen concentration at Kecks Point in Lake Carlos for 11 dates in 2010, with quantities of absolute mean error (AME) and root mean square error (RMSE). 
Additional effects on DO had to do with the transitions between different algal communities, which are described in the "Algae" section. Briefly, simplification of the algal groups into three communities (diatoms, green, and blue-green algae) can diminish the ability to realistically capture real algal communities; however, a lack of data on these different communities or on the real parameters required for the model (table 4) could also hamper the DO simulation. For example, the underprediction of DO earlier in the year (May to June) could be because of inadequately capturing all of the algal growth during this period.

\section{Elk Lake}

For the DO calibration for the Elk Lake model, the principal calibration targets were the lake profile data from the south basin hole, available from biweekly point measurements by MPCA or USGS personnel. Similar to methods for Lake Carlos, DO measurements were recorded for each meter below water surface, although some gaps were as large as $5 \mathrm{~m}$, specifically in the hypolimnion where DO changes were less drastic. Simulated and measured DO concentrations are shown for a total of 15 dates in figure 21. Overall, simulated DO concentrations tracked the measured concentrations for this location. Generally, where the greatest change in DO occurred, simulated concentrations matched the depth and slope of the measured concentrations with the exception of the early season dates of May 11, 2011, and May 24, 2011, and the later season dates of October 19, 2011, and November 8, 2011. Otherwise, AME and RMSE values were consistently less than $1.0 \mathrm{mg} / \mathrm{L}$ during the entire model simulation. The largest differences between the simulated and measured DO concentrations were in the epilimnion during the peak of the summer algal blooms. This difference is likely because of inadequately capturing the size of the algal communities or the correct composition of the algal communities, which would have an effect on the DO as a byproduct of photosynthesis. However, the model simulated the extremely low to zero DO concentrations in the hypolimnion. The model also successfully reproduced the measured metalimnetic oxygen maximum.

An additional metric for the Elk Lake calibration was provided by the 2011 sonde deployment, which included DO measurements. The sonde deployments were at the same location (south basin hole) as the point measurements. Simulated and measured DO concentrations for three depths $(2,7$, and $20 \mathrm{~m}$ ) are shown in figure 22 and listed in table 5. Reinforcing the interpretations for the different DO profiles in figure 21, the underprediction of simulated DO concentrations in the epilimnion can be seen in the plot for the 2-m depth. At the middle depth in the metalimnion $(7 \mathrm{~m}$ below the water surface), the simulated DO concentrations were closer to the measured DO concentrations. However, this was not necessarily captured by the AME and RMSE quantities (0.89 and $1.33 \mathrm{mg} / \mathrm{L}$, respectively) because of the mismatch in timing of the higher DO concentrations after mid-September. Finally, the DO concentrations in the hypolimnion $(20 \mathrm{~m}$ below the water surface) are consistently similar (low or near zero) between the simulated and measured concentrations.

As mentioned previously in the Lake Carlos section, different processes have a strong effect on the DO concentrations in a lake. As in Lake Carlos, the model decay rates of the different organic matter pools (parameters LDOMDK, RDOMDK, and LRDDK, table 4) were reasonably high. Model sediment oxygen demand (parameter SOD, table 4) also was high for Elk Lake, set to $2 \mathrm{mg} / \mathrm{L}$. The model nitrate decay rate (parameter NO3DK, table 4) was set to 0.1 per day. The combination of these three processes likely had the largest effect on the extremely low DO concentrations in the hypolimnion in Elk Lake.

\section{Trout Lake}

For the DO calibration for the Trout Lake model, the principal calibration targets were the lake profile data from the north basin hole, available from biweekly point measurements collected by MPCA or USGS personnel. Similar to methods for Lake Carlos and Elk Lake, measurements were recorded for each meter below water surface, although some gaps were as large as $5 \mathrm{~m}$, specifically in the hypolimnion where DO changes were less drastic. Simulated and measured DO concentrations are shown for a total of 15 dates in figure 23. Of the three lake models, the model for Trout Lake performed the poorest for DO concentrations but still preserved most of the overall DO trends. The model performed in terms of simulating increased DO concentrations that generally occur between 5 and $10 \mathrm{~m}$ for this lake. However, the simulated concentrations deviate from measured concentrations in both magnitude of this trend and the location depth of DO depletion later in the year (October 11, 2010 and October 20, 2010). AME and RMSE quantities were still consistently less than $1.0 \mathrm{mg} / \mathrm{L}$ during most of the model simulation.

As mentioned in the Lake Carlos and Elk Lake sections, different processes have a strong effect on the DO concentrations in a lake. Unlike Lake Carlos and Elk Lake, the decay rate of the different organic matter pools (parameters LDOMDK, RDOMDK, and LRDDK, table 4) were overall lower for Trout Lake (table 4). This was supported by overall much deeper maximum secchi depths in Trout Lake (Minnesota Pollution Control Agency, 2011b) than in Lake Carlos (Minnesota Pollution Control Agency, 2009a) and Elk Lake (Minnesota Pollution Control Agency, 2011a). Sediment oxygen demand (parameter SOD, table 4) also was much lower for Trout Lake, set to $0.33 \mathrm{mg} / \mathrm{L}$, than for the other lakes. The nitrate decay rate (parameter NO3DK, table 4) was set to 0.4 per day. The combination of these three processes likely had the largest effect on the steady, downward trend in DO concentrations in the hypolimnion of Trout Lake, where DO concentrations do not decrease to less than $1 \mathrm{mg} / \mathrm{L}$ until the lower $5 \mathrm{~m}$ of the lake. 

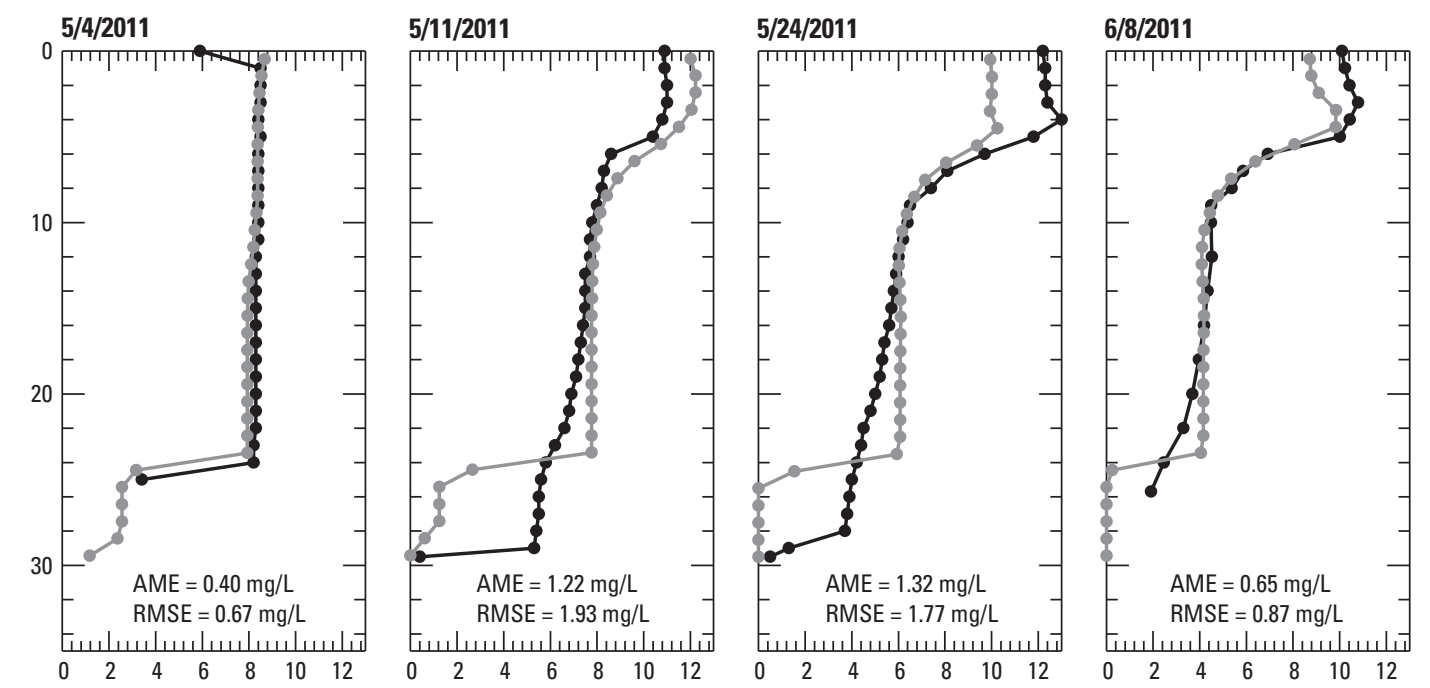

6/21/2011

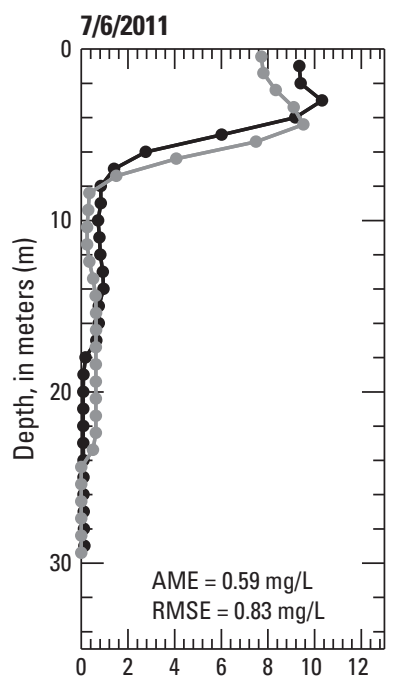

\section{7/20/2011}

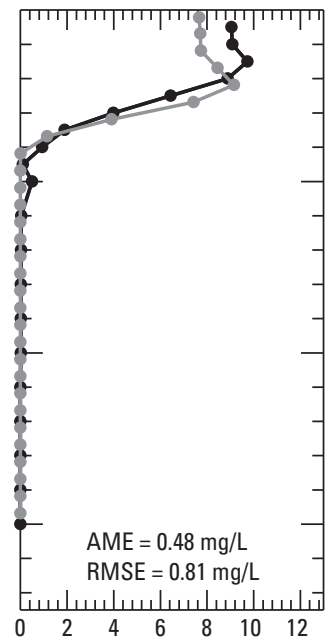

\section{8/8/2011}

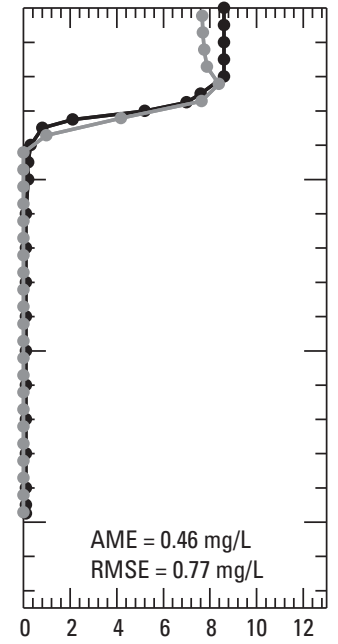

\section{8/26/2011}
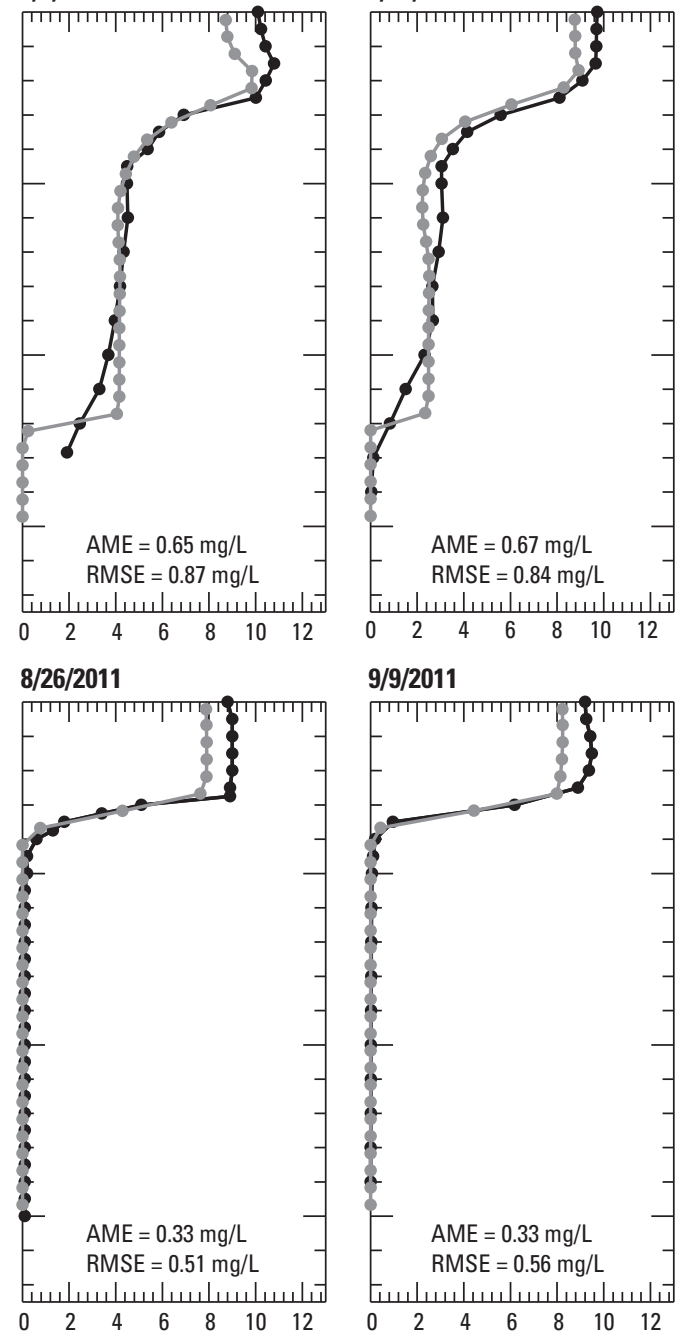

\section{9/9/2011}
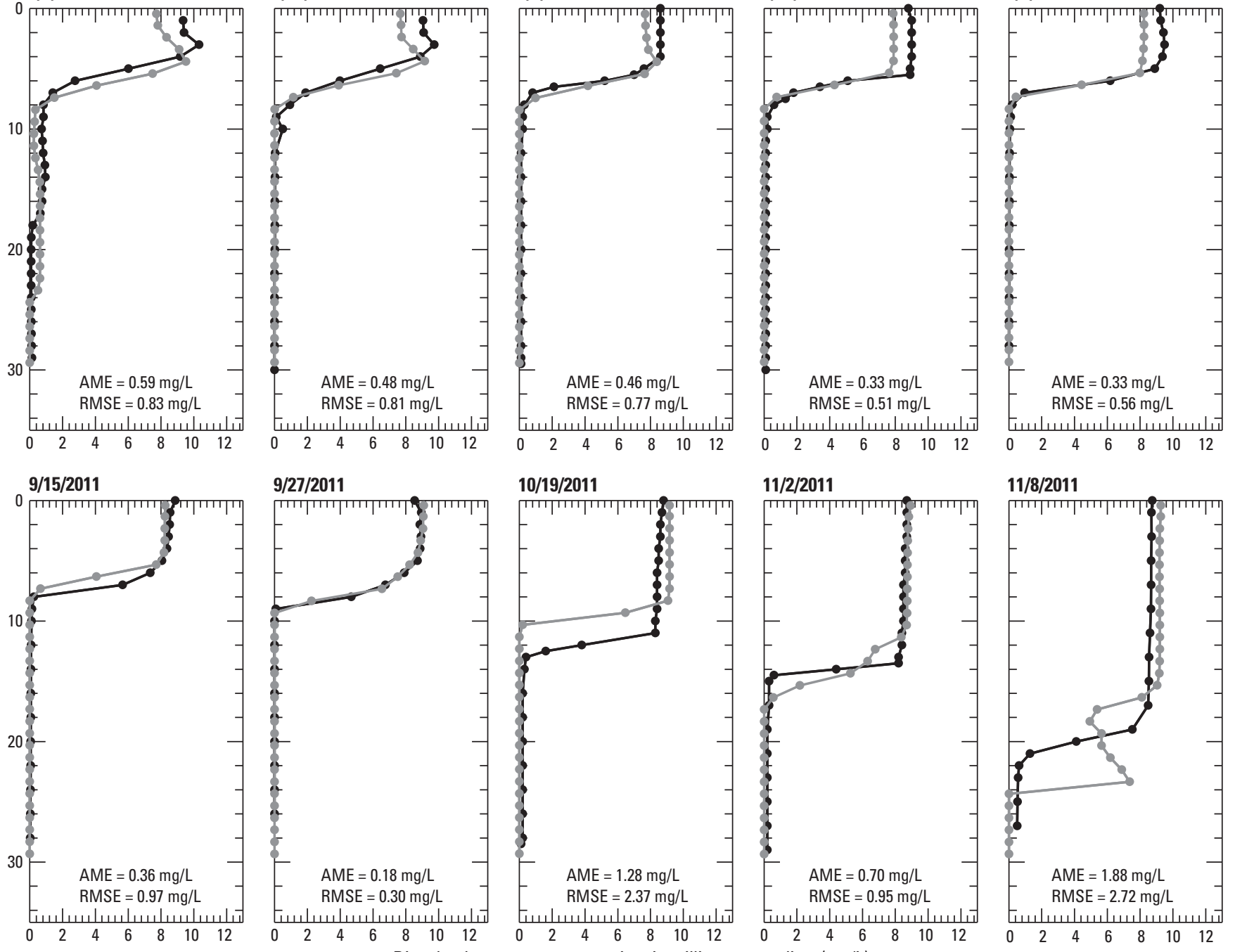

\section{$11 / 2 / 2011$}
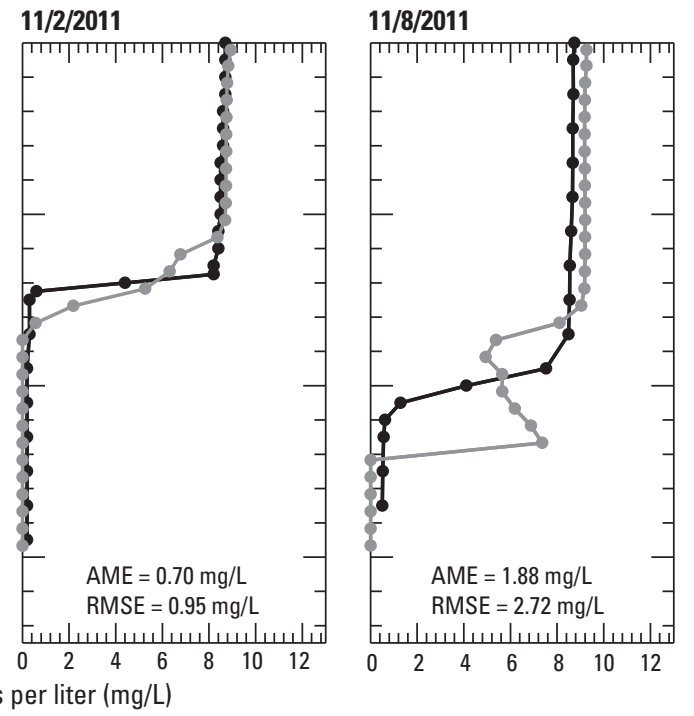

EXPLANATION

$\multimap$ Measured $\multimap$ Simulated

Figure 21. Smulated and measured dissolved oxygen concentration at the south basin hole in Elk Lake for 15 dates in 2011 , with quantities of absolute mean error (AME) and root mean square error (RMSE). 


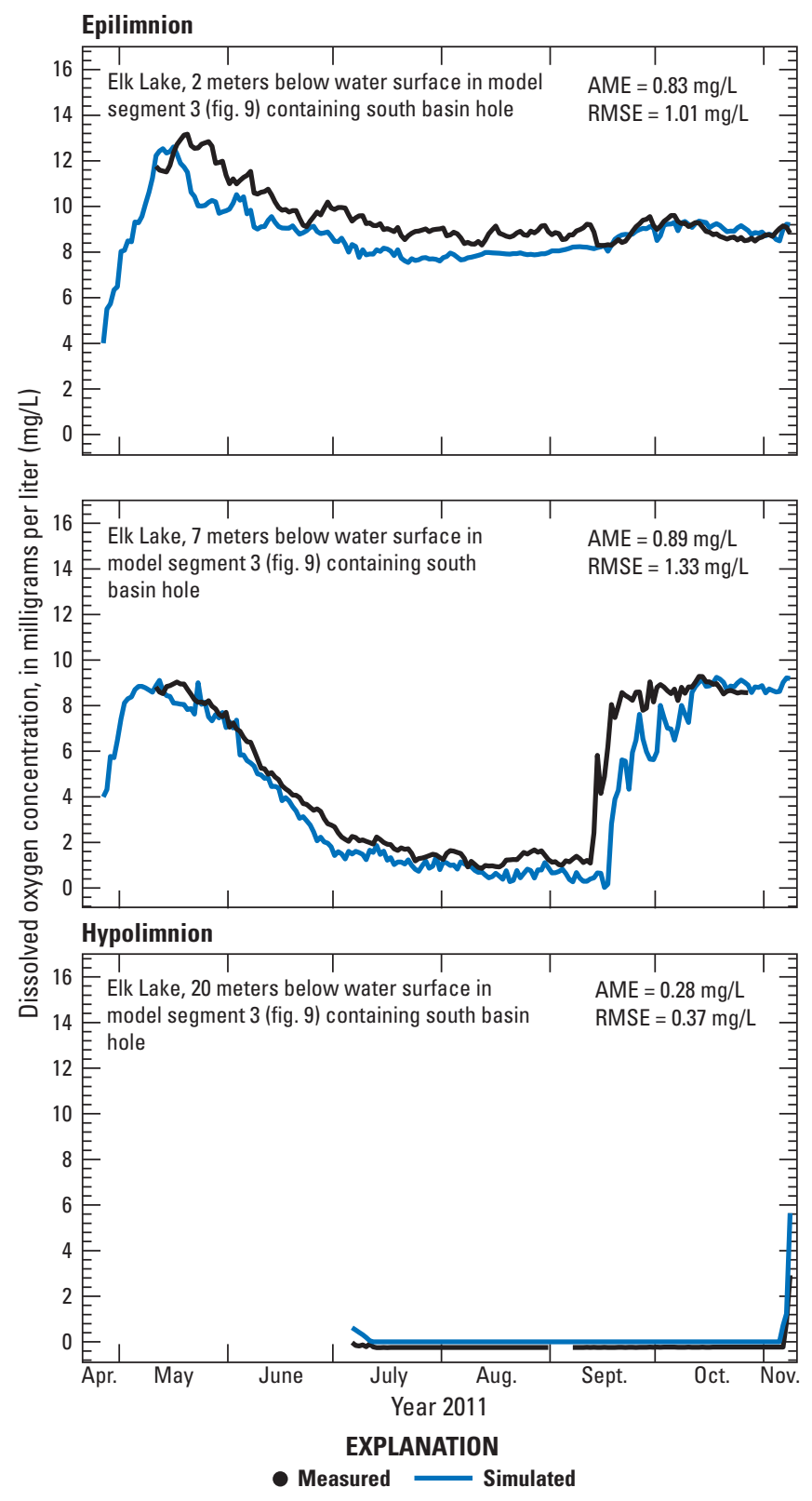

Figure 22. Continuous simulated and measured dissolved oxygen concentration at south basin hole in Elk Lake for three depths, with quantities of absolute mean error (AME) and root mean square error (RMSE), April 26, 2011, to November 8, 2011.

\section{Algae}

For all three lakes, the paradigm of three general algal groups was pursued rather than a more diverse species-specific modeling regime. This was partially because of a lack of data available at the time of model development as well as the uncertainty in model parameterization for the different groups. The three algal groups included were diatoms, green algae, and blue-green algae. Rather than including zooplankton as a separate group or groups, the zooplankton grazing dynamics were captured within algal specific constants such as the algal growth rate (parameter AG, table 4) and the algal mortality rate (parameter $\mathrm{AM}$, table 4). Algal growth temperature ranges and the fractions of growth within the temperature ranges (parameters AT1 through AT4 and parameters AK1 through AK4, table 4) were consistent across all three lake models, as were the algal growth rates (parameter AG, table 4) and the light saturation intensities at the maximum photosynthetic rate (parameter ASAT, table 4). The main guidance for the algal groups was provided by other CE-QUAL-W2 modeling efforts, specifically the Lake Waco model (Flowers and others, 2001).

\section{Lake Carlos}

The simulated distribution of three primary algal groups at $1 \mathrm{~m}$ below the water surface is shown in figure 24 for the model segment adjacent to the Lake Le Homme Dieu outlet (segment 5, fig. 8), the model segment containing the sampling site Kecks Point (segment 18, fig. 8), and the model segment adjacent to the Long Prairie River (segment 22, fig. 8). Few differences existed between the different locations in the lake; however, the biomass timing of the three algal groups did vary across all three locations. Diatoms were the first group to peak, starting in early May, peaking in mid-May to around $0.8 \mathrm{mg} / \mathrm{L}$, and then approaching $0 \mathrm{mg} / \mathrm{L}$ in the surface layer by early July. Towards the end of June, as diatoms exhibit senescence, green and blue-green algae replaced diatoms as the primary algal groups in the lake and remained fairly steady until early October. Green algae were more abundant throughout this entire period, peaking at around $0.9 \mathrm{mg} / \mathrm{L}$ by early October in the segment adjacent to the Le Homme Dieu outlet. The overall concentrations were only slightly buffered for both green and blue-green algae in the other two simulated sections shown. Starting in early October, the blue-green algae began to recede and continued this trend towards $0 \mathrm{mg} / \mathrm{L}$ through the end of the simulation in early November.

The chlorophyll $a$ concentration data were used to help interpret if the overall magnitude of the algal group composition was in the right range. Photosynthetic pigments, such as chlorophyll $a$, are accepted in the literature as surrogates for algal biomass given the high expense of measuring algal biomass directly (Lindenberg and others, 2008). Simulated values of the chlorophyll $a$ concentrations are shown in figure 25 for the same locations as shown in figure 24. Measured chlorophyll $a$ data primarily were collected in the surface layer at Kecks Point; the middle graph in figure 24 shows the grab sample measurements made by MPCA or USGS personnel at this site. Single chlorophyll $a$ measurements were made for the other two locations that correspond to sampling sites at the Lake Le Homme Dieu outlet and Long Prairie River. Overall, the simulated values were a fairly good approximation of the measured values, with AME and RMSE quantities of 2.7 and 2.9 micrograms per liter $(\mu \mathrm{g} / \mathrm{L})$, respectively, in the Kecks Point segment (fig. 25; table 5). 

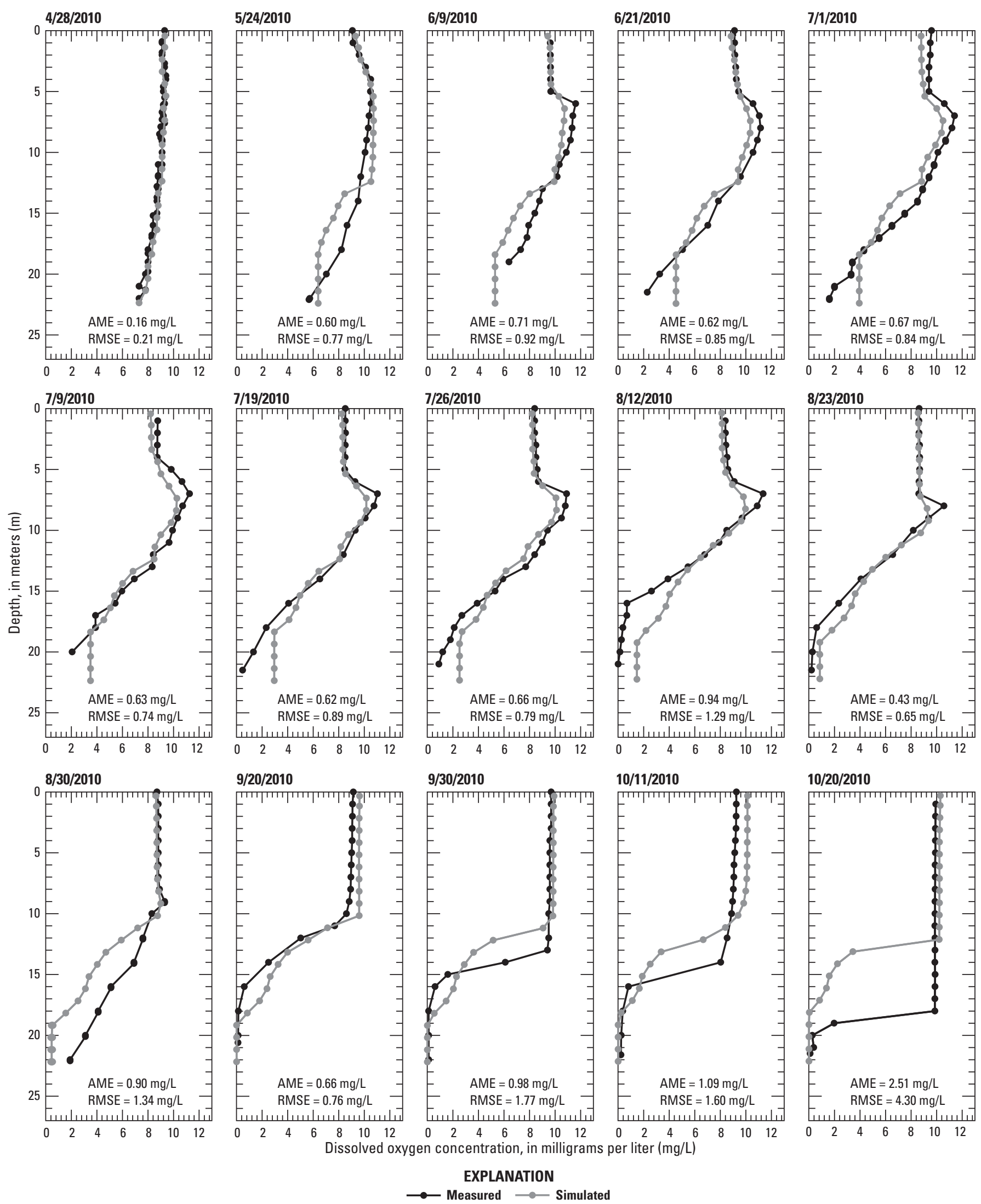

$\rightarrow$ Measured $\longrightarrow$ Simulated

Figure 23. Simulated and measured dissolved oxygen concentration at the north basin hole in Trout Lake for 15 dates in 2010, with quantities of absolute mean error (AME) and root mean square error (RMSE). 


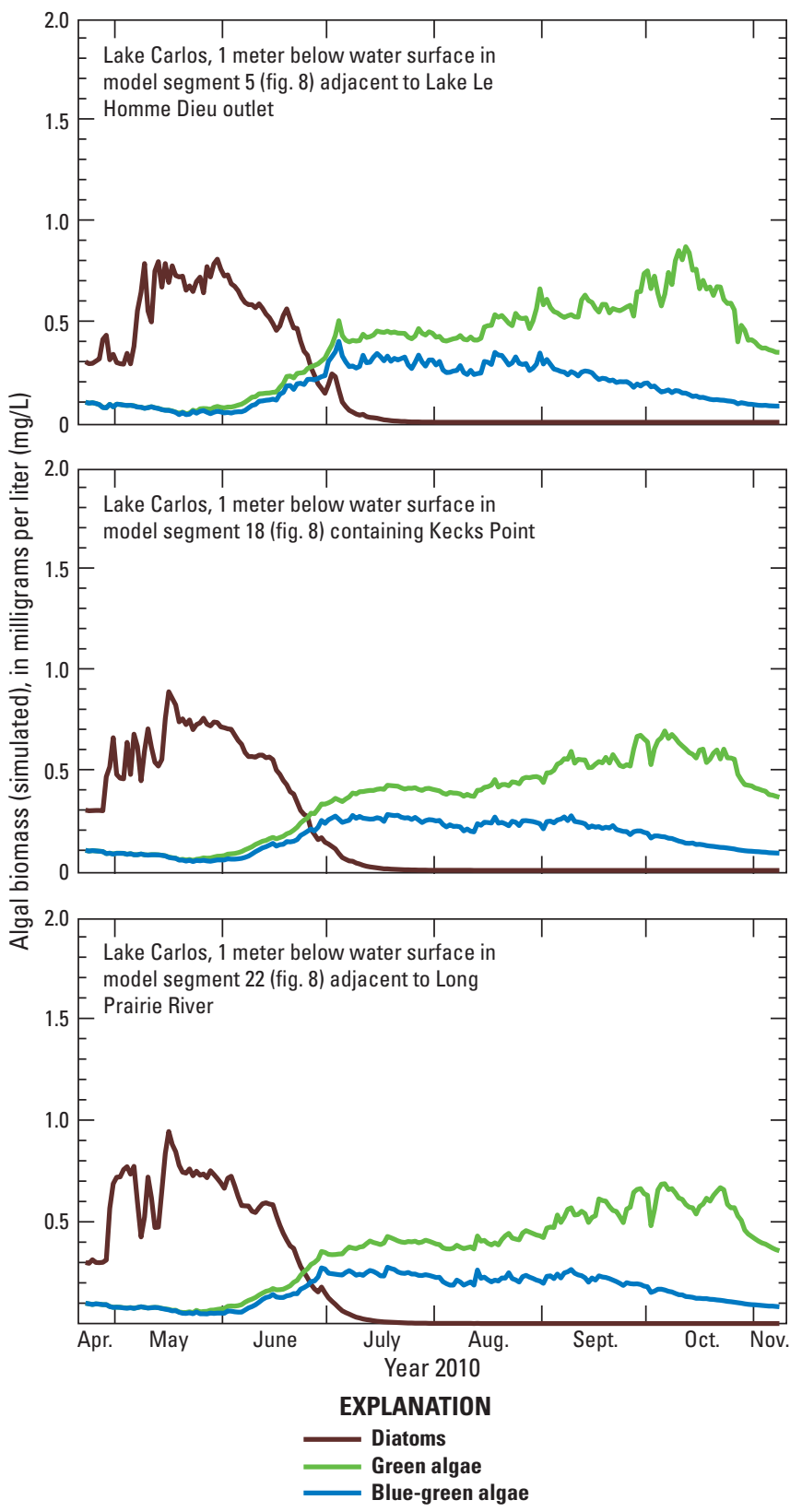

Figure 24. Simulated algal group distributions (diatoms, green, and blue-green algae) for three model segments for Lake Carlos, April 20, 2010, to November 10, 2010.

The simulated concentrations of the algal groups and chlorophyll $a$ were highly dependent on the parameterization of the algal groups. Given the many parameters related to the algal groups (table 4) and their overall effect on the DO, these parameters can be extremely difficult to quantify. Many of the parameters were highly sensitive, such as the algal mortality, algal settling rate, temperature coefficients on maximum growth, and the algal half-saturation constants for nitrogen- and phosphorus-limited growth; however, several of the parameters were fixed for each group across all three lakes. The maximum algal respiration rate (parameter AR, table 4),

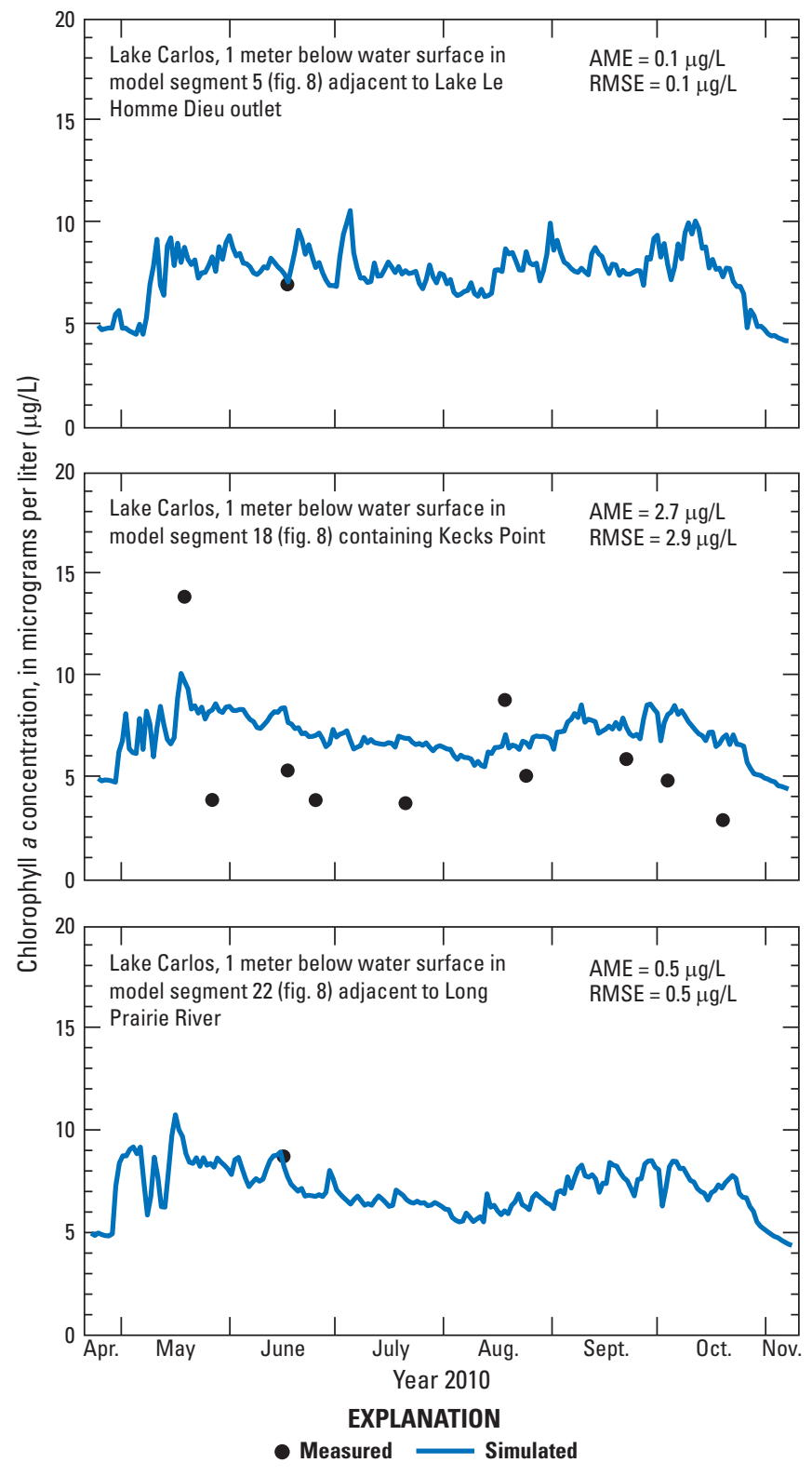

Figure 25. Simulated and measured chlorophyll a concentrations for three model segments in Lake Carlos, April 20, 2010, to November 10,2010, with quantities of absolute mean error (AME) and root mean square error (RMSE).

algal excretion rate (parameter $\mathrm{AE}$, table 4), algal mortality (parameter AM, table 4), and the algal half-saturation for both nitrogen- (parameter AHSN, table 4) and phosphorus-limited growth (parameter AHSP, table 4) were varied to optimize the fit between the chlorophyll $a$ data and the DO profiles. The settling rate (parameter AS, table 4), which limited algal growth, was highest for Lake Carlos among the three lakes (table 4). Another group of parameters that limited growth was the constants chosen for the nitrogen- and phosphorus-limited growth (Cole and Wells, 2008), which generally was set slightly higher overall for Lake Carlos compared to the other 
two lakes. The algal growth also was strongly related to the availability of nutrients, which was dependent on the initial lake concentrations and the ongoing replenishment of nutrients from the various inflow sources. The chlorophyll $a$ concentrations were affected by the same factors as the algal group composition but also were affected by the chosen ratio between algal biomass and chlorophyll $a$ (parameter ACHLA, table 4). This ratio was 0.1 for all three groups (diatoms, green, and blue-green algae) in Lake Carlos, in terms of milligrams of algae to micrograms of chlorophyll $a$.

\section{Elk Lake}

The simulated distribution of three primary algal groups for Elk Lake is shown in figure 26. The simulated results are shown for two depths ( $2 \mathrm{~m}$ and $20 \mathrm{~m}$ below water surface) for the same location, the south basin hole. Similar to the algal group dynamics for Lake Carlos, the biomass timing of the three algal groups did vary considerably. In the surface layer (2-m depth), diatoms were the first group to peak, starting in early May, peaking in mid-May at about $3.0 \mathrm{mg} / \mathrm{L}$, and then the diatoms approached $0 \mathrm{mg} / \mathrm{L}$ by mid-June. The spike in

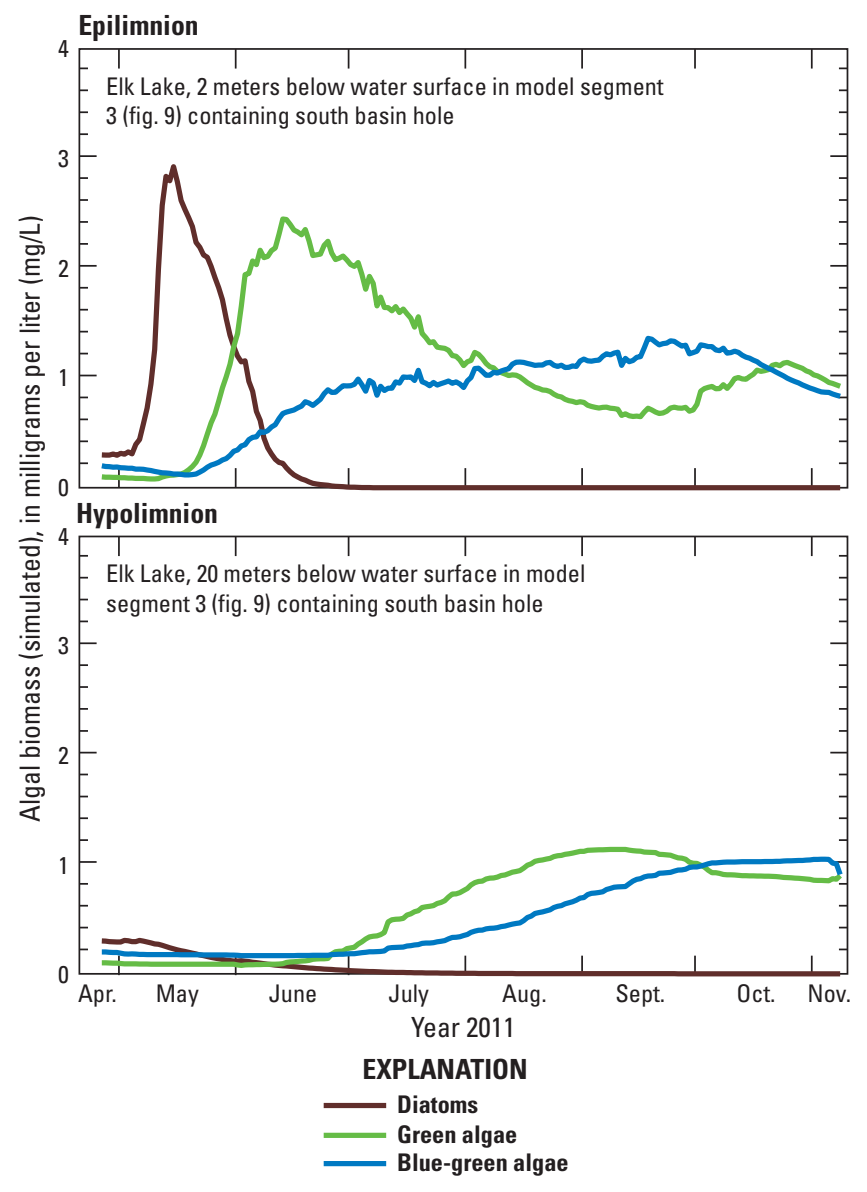

Figure 26. Simulated algal group distributions (diatoms, green, and blue-green algae) for two depths at the south basin hole in Elk Lake, April 26, 2011, to November 8, 2011. diatoms was more distinct for Elk Lake than Lake Carlos. As diatoms receded in late May, the diatoms were replaced by green algae and to a lesser degree blue-green algae. Greenalgae biomass peaked at $2.5 \mathrm{mg} / \mathrm{L}$ by mid-June, with a smaller secondary peak in mid-October. Between these two peaks, the green algae concentration receded to a low of $0.6 \mathrm{mg} / \mathrm{L}$ in mid-September. Blue-green algae increased at a slower rate compared to green algae and peaked in concentration by late September but did not exceed $1.5 \mathrm{mg} / \mathrm{L}$. The simulated results for the 20-m depth also illustrate the model's prediction of fairly high algal concentrations at depth for both green and blue-green algae (fig. 26). Although the simulated results are not necessarily unrealistic, it is important to note the potential drawback of the parameterization scheme of the CE-QUALW2 model that can lead to unrealistically high algal concentrations at depth.

Similar to Lake Carlos, algal group composition for Elk Lake was lacking at the time of model development, and the chlorophyll $a$ concentration data were used to interpret overall magnitudes. The simulated results of the chlorophyll $a$ concentrations in micrograms per liter are shown in figure 27 for the same depths as shown in figure 26. Measured data were collected only in the surface layer (2-m depth) for the south basin hole. Overall, the simulated results were a fairly good approximation of the measured concentrations, with AME and RMSE values of 2.7 and $3.4 \mu \mathrm{g} / \mathrm{L}$, respectively, without any major discrepancies between the simulated and measured concentrations (fig. 27; table 5).

As mentioned in the Lake Carlos section, the simulated concentrations were highly sensitive to parameters such as the algal mortality, algal settling rate, temperature coefficients on maximum growth, and the algal half-saturation constants for nitrogen and phosphorus-limited growth. For Elk Lake, the settling rate (parameter AS, table 4) was only slightly lower than the rate used for Lake Carlos. Optimization was stressed for the algal half-saturation constants for the nitrogen- and phosphorus-limited growth (parameters AHSN and AHSP, respectively). The highest limits were set for diatoms, with much lower constants set for green and blue-green algae to maximize the known algal blooms for these two groups. As in Lake Carlos, the algal growth also was strongly related to the availability of nutrients and particularly sensitive to the much higher ammonia concentration in Elk Lake compared to the other two lakes (table 3 ). The chlorophyll $a$ concentrations were strongly affected by the much higher ratio of 0.28 for parameter ACHLA (table 4) for all three groups in Elk Lake, in terms of milligrams of algae to micrograms of chlorophyll $a$.

\section{Trout Lake}

The simulated distribution of three primary algal groups for Trout Lake is shown in figure 28. The simulated results at two depths ( $1 \mathrm{~m}$ and $18 \mathrm{~m}$ below water surface) for the same location, the north basin hole, are shown in figure 28. Similar to the algal group dynamics for Lake Carlos and Elk Lake, 


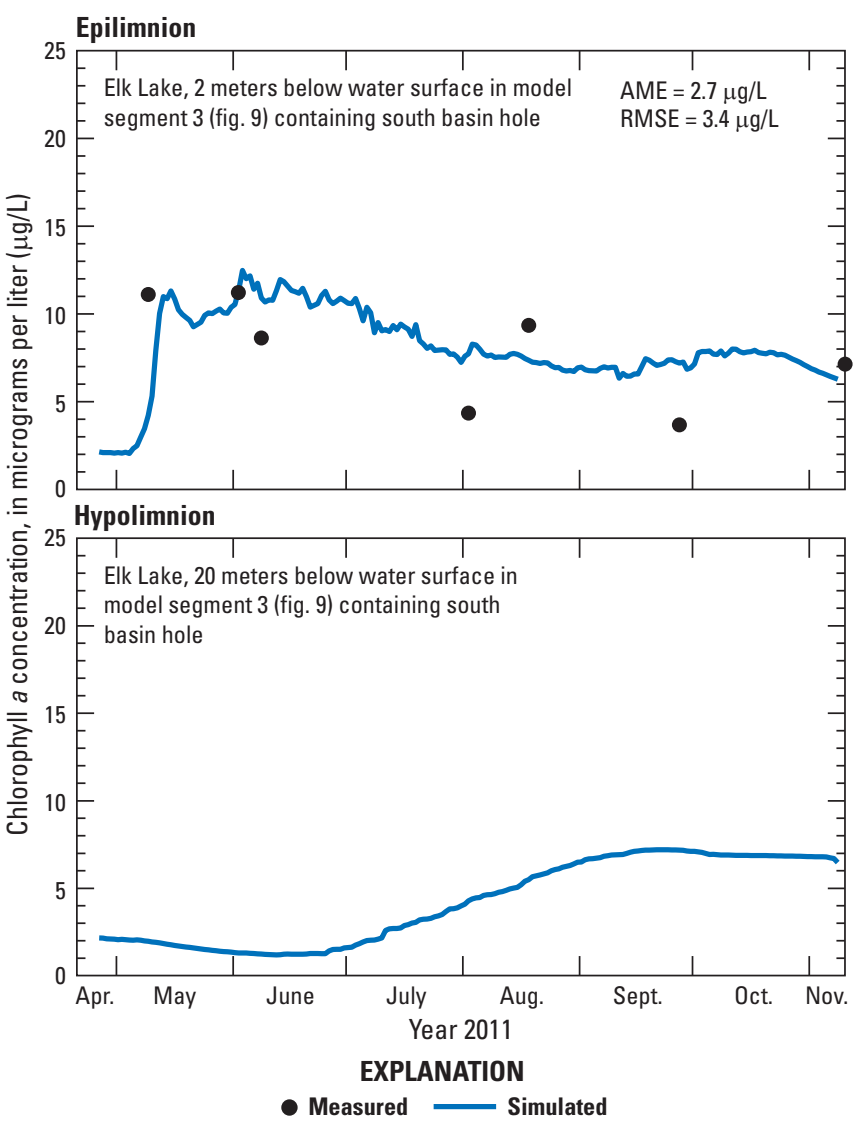

Figure 27. Simulated and measured chlorophyll a concentrations for two depths at the south basin hole in Elk Lake, April 26, 2011, to November 8, 2011, with quantities of absolute mean error (AME) and root mean square error (RMSE).

the biomass timing of the three algal groups varied considerably. However, the algal bloom dynamics were more subtle in comparison to the other two lakes. Generally, diatoms were stable at about $1 \mathrm{mg} / \mathrm{L}$ until mid-July when green algae increased and remained at a stable concentration of about $1 \mathrm{mg} / \mathrm{L}$. Blue-green algae had one concentration spike in early June to almost $1 \mathrm{mg} / \mathrm{L}$, but this blue-green algae bloom was short-lived. At depth (18 m), simulated biomass concentrations of all three groups were low.

Similar to both Lake Carlos and Elk Lake, no supporting data for algal group composition at the time of model development were available, and the chlorophyll $a$ concentration data were used to interpret overall algal population dynamics. The simulated chlorophyll $a$ concentrations are shown in figure 29 for the same depths as shown in figure 28. Measured chlorophyll $a$ data were collected from the surface layer $(1 \mathrm{~m}$ below water surface) and at depth (18 $\mathrm{m}$ below water surface) for the north basin hole. Overall, simulated values at the 18-m depth matched measured values better than those at the 1-m depth, with AME and RMSE values of 2.1 and $2.8 \mu \mathrm{g} / \mathrm{L}$, respectively, at $18-\mathrm{m}$ depth and 5.0 and $5.3 \mu \mathrm{g} / \mathrm{L}$, respectively, at $1-\mathrm{m}$ depth (fig. 29; table 5).
For Trout Lake, the algal settling rate (parameter AS, table 4) was the lowest for all three algal groups in comparison to the other two lakes. Optimization also was stressed in the Trout Lake model for the algal half-saturation constants for the nitrogen- and phosphorus-limited growth (parameters AHSN and AHSP, respectively) given the low concentrations of nitrogen and phosphorus. Contrary to the other two lakes, the algal half-saturation constant for nitrogen, which simulates nitrogen fixation in the CE-QUAL-W2 model, was set to zero for the blue-green algae (table 4). This assumption seemed reasonable for Trout Lake because of the sustained algal community but much lower nutrient loads overall, as indicated by the initial nutrient concentrations (table 3), compared to the other two lakes. The chlorophyll $a$ concentrations also were strongly affected by the lower ratio of 0.12 for parameter ACHLA (table 4) for all three algal groups in Trout Lake compared to Elk Lake, in terms of milligrams of algae to micrograms of chlorophyll $a$.

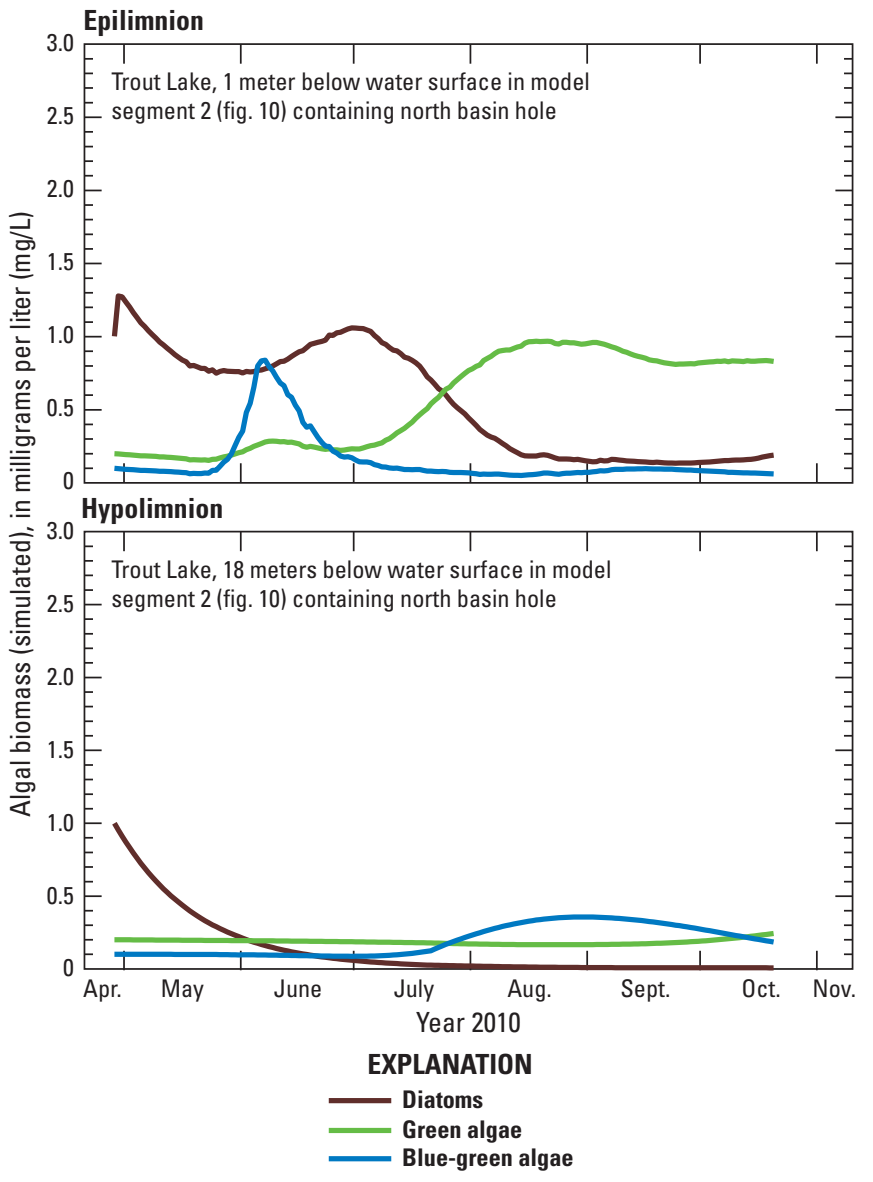

Figure 28. Simulated algal group distributions (diatoms, green, and blue-green algae) for two depths at the north basin hole in Trout Lake, April 28, 2010, to October 21, 2010. 


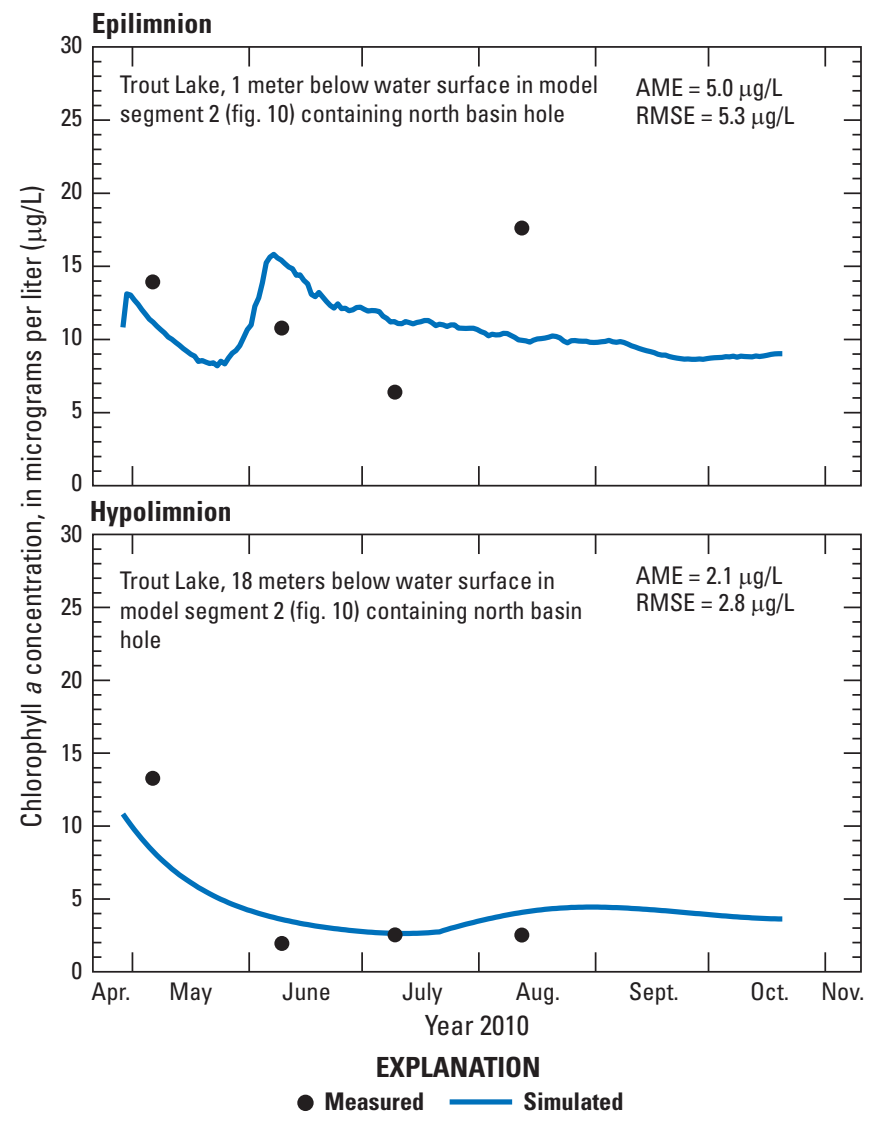

Figure 29. Simulated and measured chlorophyll a concentrations for two depths at the north basin hole in Trout Lake, April 28, 2010, to October 21, 2010, with quantities of absolute mean error (AME) and root mean square error (RMSE).

\section{Nutrients}

Nutrients for all three lakes are controlled by many processes. One of the most important controls is the amount of nutrients (loads) contributed by the inflows, which are different for each of the three lakes. These loads would be expected to vary across ecoregions, with the soil fertility in the contributing drainage basin, and across different land uses (for example, row-crop agriculture compared to deciduous forest). After the water is in the lake, in-lake processing of the nutrients is the major factor controlling nutrient concentrations. The focus for evaluating the model calibration was given to three constituents of nitrogen and two constituents of phosphorus: nitrate plus nitrite, ammonia, total nitrogen, orthophosphorus, and total phosphorus.

Sources and sinks are largely the same for all three lakes, although distinctions can be made in terms of the major inflows. Lake Carlos largely is controlled by the inflows from Lake Darling and Lake Le Homme Dieu, whereas Trout Lake and Elk Lake seem to have considerably more groundwater or spring sources relative to surface inflows. For nitrate plus nitrite, sources include all inflows and ammonia nitrification; sinks include denitrification (both in the water column and sediments), algal uptake, and lake outflow (Cole and Wells, 2008). For ammonia, which lumps both ammonia $\left(\mathrm{NH}_{3}\right)$ and ammonium $\left(\mathrm{NH}_{4}^{+}\right)$, sources include all inflows, decay of all organic matter pools, sediment release under anaerobic conditions, and algal respiration; sinks include nitrification, algal uptake, and lake outflow (Cole and Wells, 2008). For orthophosphorus, sources include all inflows, decay of all organic matter pools, sediment release under anaerobic conditions, and algal respiration; sinks include particles settling with adsorbed phosphorus, algal uptake, and lake outflow (Cole and Wells, 2008). For purposes of comparing simulated and measured concentrations, total nitrogen was classified as the concentration of nitrogen present in ammonia, nitrate plus nitrite, and organically bound nitrogen (both in living algal biomass and all organic matter pools). For purposes of comparing simulated and measured concentrations, total phosphorus was classified as the concentration of phosphorus present in orthophosphorus and bound up in organic matter (both in living algal biomass and all organic matter pools).

The primary tools for evaluating the degree of fit for the nutrients were the AME and RMSE values (table 5). It is worth noting that these values could often be largely offset by only one or two measured samples because of the small number of total samples.

\section{Lake Carlos}

Ammonia and nitrate plus nitrite distributions in Lake Carlos were largely affected by the inflows and the lake hydrodynamics. The simulated and measured concentrations of ammonia as nitrogen $(\mathrm{N})$ at $1 \mathrm{~m}$ below the water surface are shown in figure 30 for the model segment adjacent to the Lake Le Homme Dieu outlet (segment 5, fig. 8), the segment containing Kecks Point (segment 18, fig. 8), and the segment adjacent to the Long Prairie River (segment 22, fig. 8). Simulated and measured concentrations at $20 \mathrm{~m}$ below water surface also are shown in figure 30 for the segment containing Kecks Point. Few differences in ammonia concentrations were noted among the epilimnion locations (1-m depth) in the lake as the simulation and measured concentrations were relatively stable in the epilimnion for most of the year. Algal uptake likely was fairly rapid, with replenishment by organic matter decay and inflows. At the 20 -m depth in the hypolimnion, ammonia concentrations increased to a peak in late June, then decreased. This increase in the hypolimnion can be explained, in part, by organic matter decay without algal uptake and by inflow replacement earlier in the year because of thermal density gradients.

Simulated and measured nitrate plus nitrite concentrations are shown in figure 31 for the same locations and depths as shown in figure 30 for ammonia. Even further nitrogen depletion was simulated for nitrate plus nitrite concentrations across all three epilimnion locations (1-m depth). At the 20-m depth in the hypolimnion, the simulated increase in nitrate plus nitrite concencentrations was delayed relative to the increase 

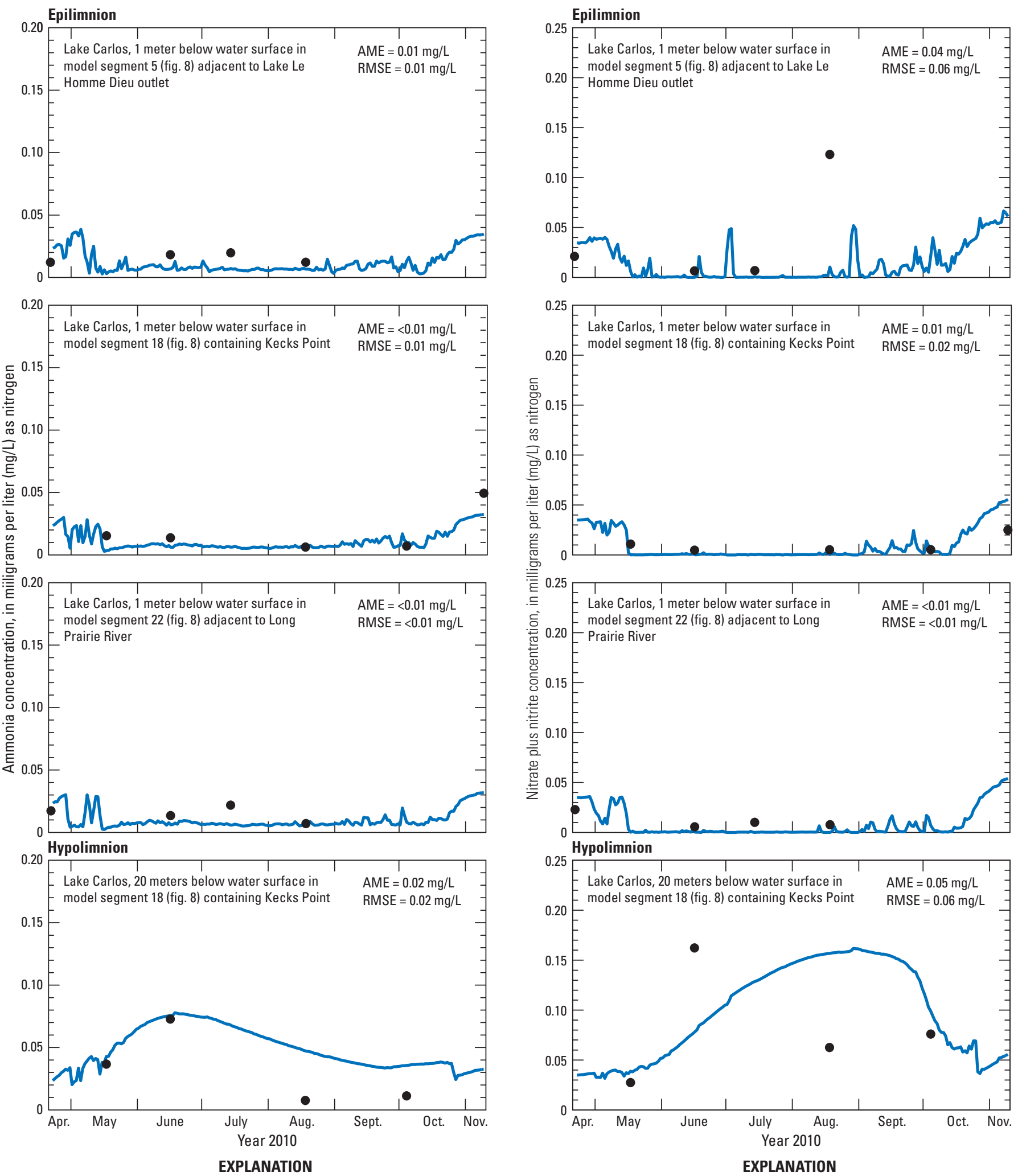

EXPLANATION

- Measured — Simulated

- Measured — Simulated

Figure 30. Simulated and measured ammonia concentrations for three epilimnetic model segments (segments 5, 18, and 22) and a hypolimnetic model segment (segment 18) for Lake Carlos, April 20, 2010, to November 10, 2010, with quantities of absolute mean error (AME) and root mean square error (RMSE).

Figure 31. Simulated and measured nitrate plus nitrite concentrations for three epilimnetic model segments (segments 5,18 , and 22) and a hypolimnetic model segment (segment 18) for Lake Carlos, April 20, 2010, to November 10, 2010, with quantities of absolute mean error (AME) and root mean square error (RMSE). 
in the ammonia concentrations (fig. 30) because of ammonia nitrification of the earlier influx in the late spring and early summer. Towards the end of the simulation period, the nitrate plus nitrite concentration becomes increasingly depleted without a steady source of ammonia for nitrification, likely because of nitrate decay.

The AME and RMSE values for ammonia were low overall because of the low concentrations and ranged from less than $(<) 0.01$ to $0.02 \mathrm{mg} / \mathrm{L}$ (table 5). The AME quantities for nitrate plus nitrite ranged from $<0.01$ to $0.05 \mathrm{mg} / \mathrm{L}$, with the highest value for the hypolimnion; RMSE quantities for nitrogen-nitrite ranged from $<0.01$ to $0.06 \mathrm{mg} / \mathrm{L}$ (table 5).

Orthophosphorus concentrations in Lake Carlos were largely affected by the inflows and the lake hydrodynamics. Orthophosphorus concentrations, in the simulation results and measured data, were relatively stable in the epilimnion for most of the year. Algal uptake is fairly rapid, with replenishment by organic matter decay and inflows. However, at the end of the simulation period, a steady increase in orthophosphorus concentrations occurred primarily because of increased loads from the Lake Le Homme Dieu outlet. This increase was even more pronounced in the hypolimnion, where increased loads and the lack of algal uptake were contributing factors. The AME and RMSE values for orthophosphorus were low overall because of the low concentrations, and all were $<0.01 \mathrm{mg} / \mathrm{L}$ (fig. 32; table 5).

Simulated and measured concentrations are shown for total nitrogen (fig. 33) and total phosphorus (fig. 34). The AME values for total nitrogen in the epilimnion (1-m depth) were all $0.12 \mathrm{mg} / \mathrm{L}$, with RMSE values for total nitrogen ranging from 0.12 to $0.14 \mathrm{mg} / \mathrm{L}$ (table 5). The AME and RMSE values for total nitrogen in the hypolimnion were 0.04 and $0.05 \mathrm{mg} / \mathrm{L}$, respectively (table 5 ). The measured data indicate a relatively stable amount of total nitrogen in the lake, whereas the simulated results show a slow and steady decrease over the simulation period (fig. 33). This decrease was likely because of the overall decay of the simulated organic matter pools and the decrease in simulated total algal biomass. Total phosphorus was affected by the same factors as total nitrogen but was a much smaller pool (by three orders of magnitude) and was an overall smaller portion of algal biomass. Also, the total phosphorus concentration was stable in the hypolimnion because of the offset between increasing orthophosphorus concentrations (fig. 32) and the decreasing amount of overall algal biomass (fig. 24). The AME values for total phosphorus ranged from 1 to $3 \mu \mathrm{g} / \mathrm{L}$, and RMSE values ranged from 1 to $4 \mu \mathrm{g} / \mathrm{L}$ (table 5 ).

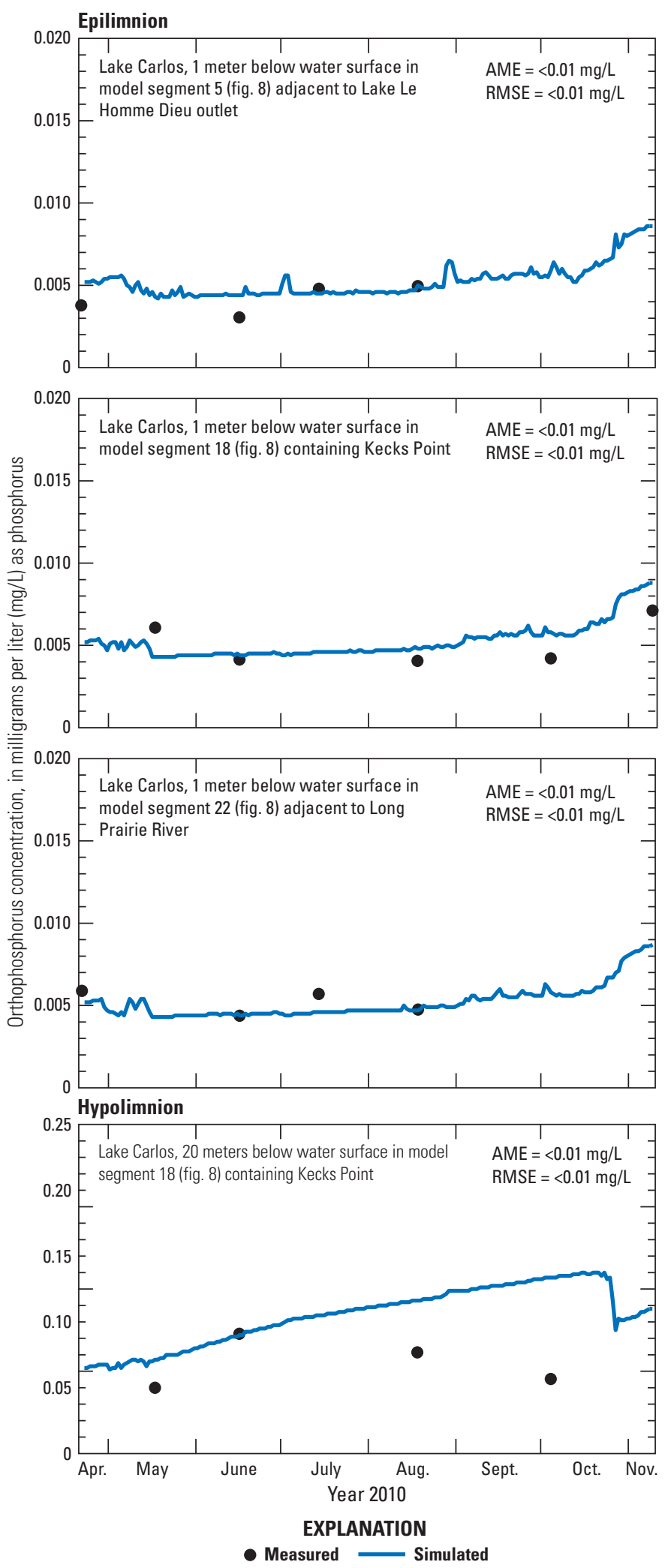

Figure 32. Simulated and measured orthophosphorus concentrations for three epilimnetic model segments (segments 5,18 , and 22) and a hypolimnetic model segment (segment 18) for Lake Carlos, April 20, 2010, to November 10, 2010, with quantities of absolute mean error (AME) and root mean square error (RMSE). 
Epilimnion
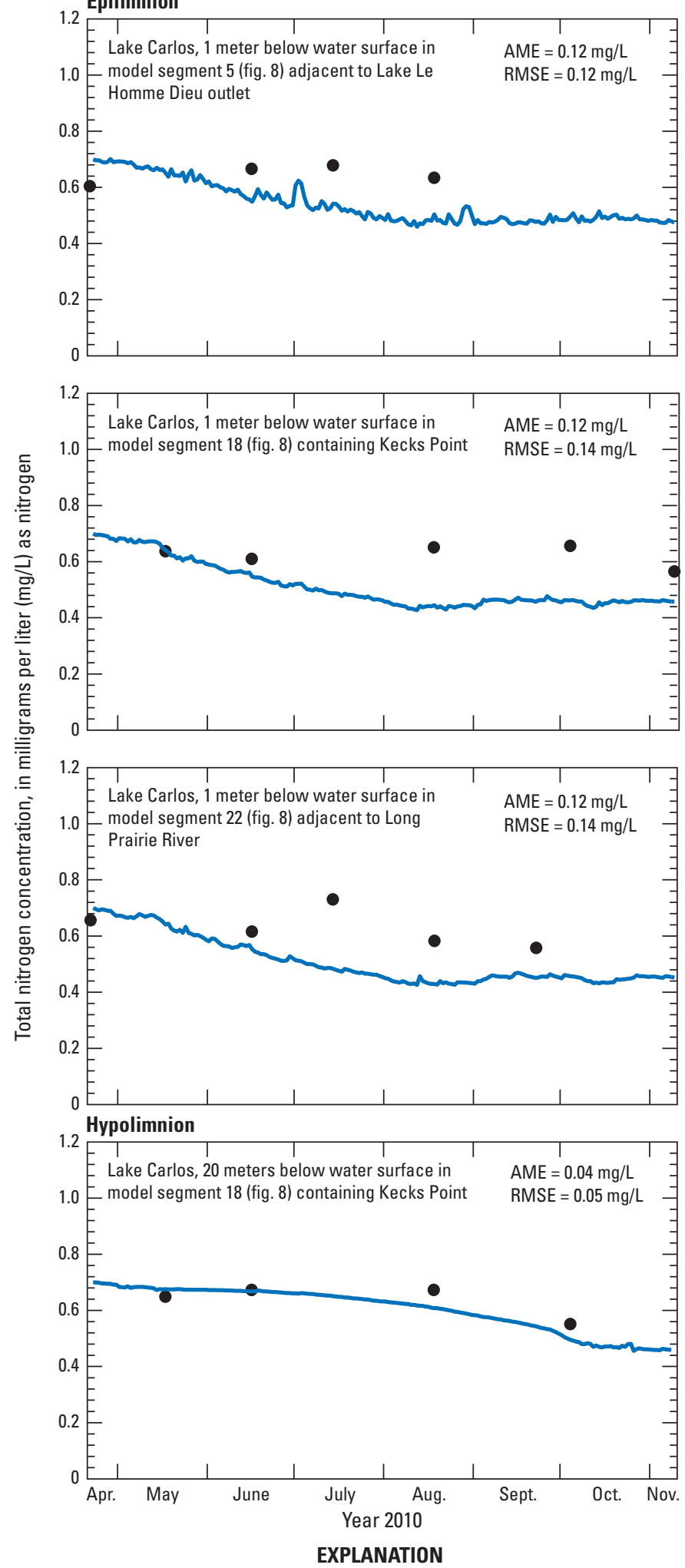

- Measured $=$ Simulated

Figure 33. Simulated and measured total nitrogen concentrations for three epilimnetic model segments (segments 5,18 , and 22) and a hypolimnetic model segment (segment 18) for Lake Carlos, April 20, 2010, to November 10, 2010, with quantities of absolute mean error (AME) and root mean square error (RMSE).
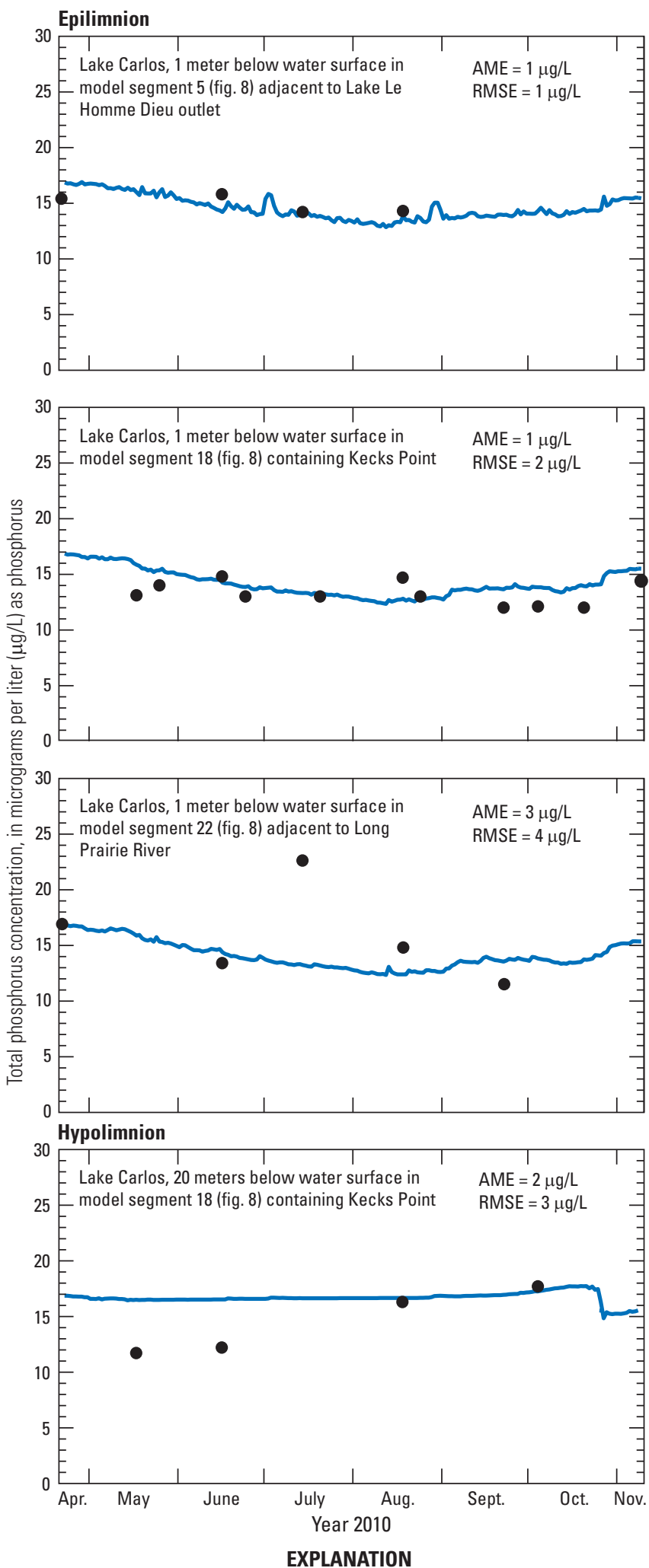

- Measured Simulated

Figure 34. Simulated and measured phosphorus concentrations for three epilimnetic model segments (segments 5,18 , and 22) and a hypolimnetic model segment (segment 18) for Lake Carlos, April 20,2010 , to November 10, 2010, with quantities of absolute mean error (AME) and root mean square error (RMSE). 


\section{Elk Lake}

Ammonia and nitrate plus nitrite concentrations in Elk Lake largely were affected by the inflows and the lake hydrodynamics, similar to Lake Carlos. The simulated and measured ammonia concentrations are shown for the south basin hole for depths of $2 \mathrm{~m}$ and $20 \mathrm{~m}$ below water surface (fig. 35). For the epilimnion (2-m depth), the initially high ammonia concentration in the lake was quickly depleted by algal uptake, as noted by the large diatom bloom in May (fig. 26). After this initial bloom, ammonia from inflows and algal respiration was quickly recycled into more algal biomass. In the hypolimnion (20-m depth), ammonia was depleted at a much slower rate than in the epilimnion because of nitrification into nitrate; however, without algal uptake, a fairly large ammonia pool remained. The simulated nitrate plus nitrite concentrations for the epilimnion show a small peak in mid-May, likely because of algal excretion, ammonia nitrification, or both (fig. 36). In the hypolimnion, a substantial buildup of nitrate occurred, likely because of the combined effects of inflows and ammonia nitrification, although this buildup was offset later in the simulation period by nitrate decay (denitrification). The AME values for ammonia ranged from 0.05 to $0.42 \mathrm{mg} / \mathrm{L}$, with the

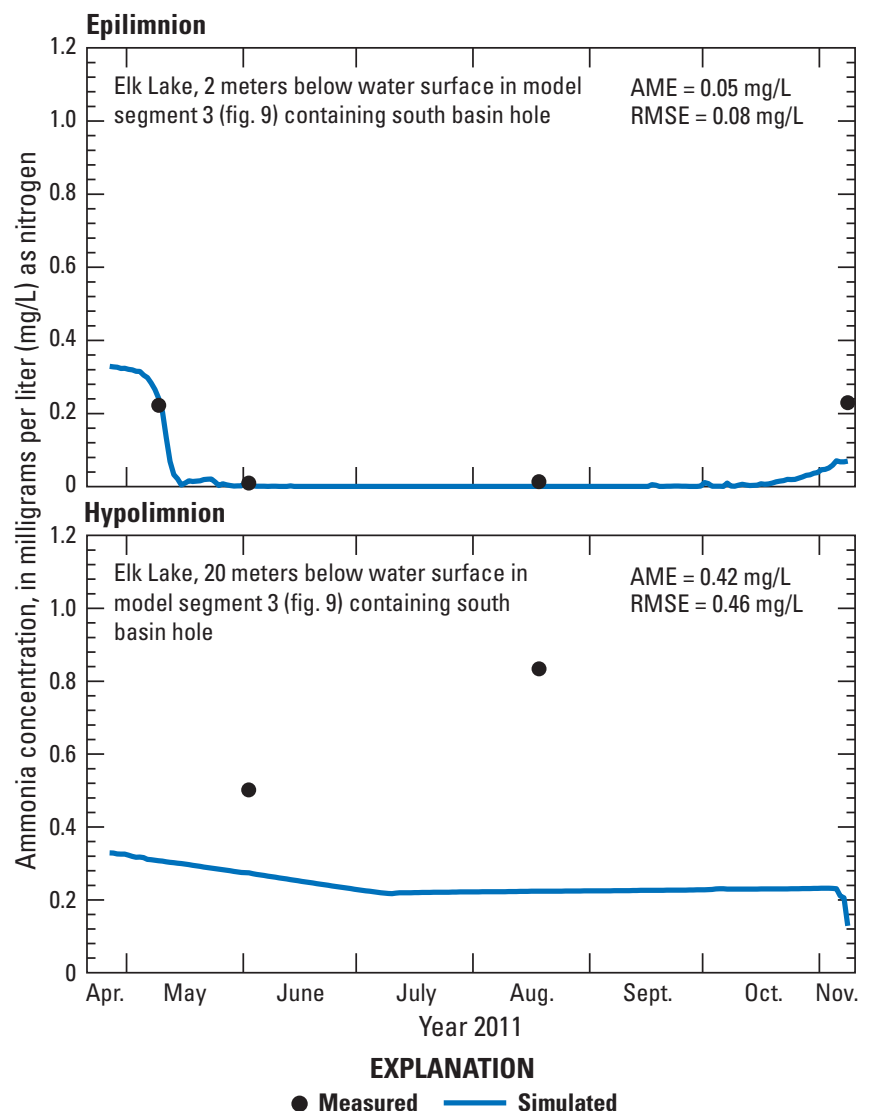

Figure 35. Simulated and measured ammonia concentrations for two depths at the south basin hole in Elk Lake, April 26, 2011, to November 8, 2011, with quantities of absolute mean error (AME) and root mean square error (RMSE).

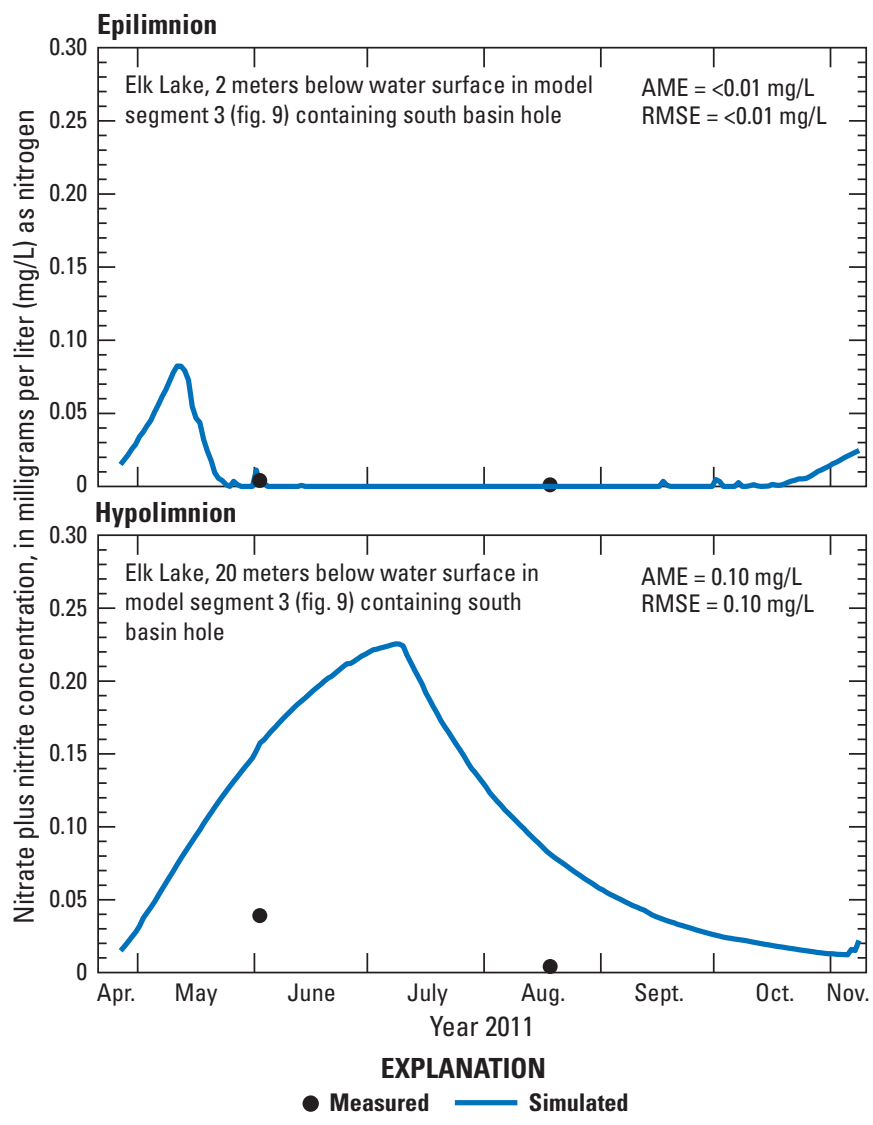

Figure 36. Simulated and measured nitrate plus nitrite concentrations for two depths at the south basin hole in Elk Lake, April 26, 2011, to November 8, 2011, with quantities of absolute mean error (AME) and root mean square error (RMSE).

highest value in the hypolimnion; the RMSE values ranged from 0.08 to $0.46 \mathrm{mg} / \mathrm{L}$ (fig. 35; table 5). The AME values for nitrate plus nitrite ranged from $<0.01$ to $0.10 \mathrm{mg} / \mathrm{L}$, with the highest value also in the hypolimnion; the RMSE values ranged from $<0.01$ to $0.10 \mathrm{mg} / \mathrm{L}$ (fig. 36; table 5).

Orthophosphorus concentrations in Elk Lake largely were affected by the inflows and the lake hydrodynamics. For most of the year, orthophosphorus concentrations, in the simulation and measured data, were relatively stable in the epilimnion (fig. 37). As in Lake Carlos, algal uptake was likely fairly rapid, with replenishment by organic matter decay and inflows. Early in the simulation period, orthophosphorus depletion coincided with the diatom bloom (fig. 26). In the hypolimnion, orthophosphorus concentrations slowly increased without major algal uptake and without the steady decay of the various organic matter pools. The AME and RMSE values for orthophosphorus in the epilimnion were low overall because of the low concentrations, and all were $<0.01 \mathrm{mg} / \mathrm{L}$; the AME and RMSE values in the hypolimnion were higher $(0.10 \mathrm{mg} / \mathrm{L})$ because of the mismatch for the slow buildup in the simulation results, which was not reflected in the measured data (fig. 37; table 5). 


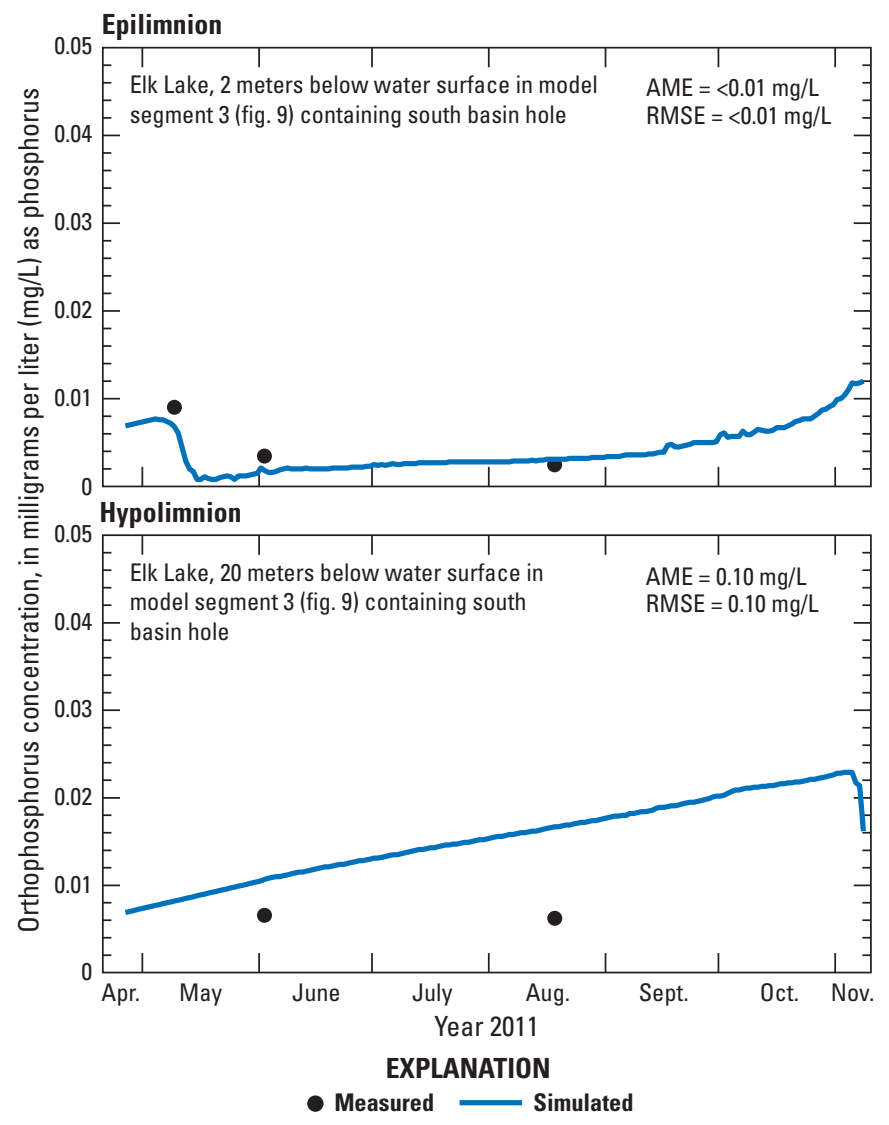

Figure 37. Simulated and measured orthophosphorus concentrations for two depths at the south basin hole in Elk Lake, April 26, 2011, to November 8, 2011, with quantities of absolute mean error (AME) and root mean square error (RMSE).

Simulated and measured concentrations are shown for total nitrogen (fig. 38) and total phosphorus (fig. 39) concentrations for two depths at the south basin hole. The AME values for total nitrogen in the epilimnion for the south basin hole and Elk Lake outlet were 0.12 and $0.17 \mathrm{mg} / \mathrm{L}$, respectively. The RMSE values were 0.17 and $0.18 \mathrm{mg} / \mathrm{L}$ for the south basin hole and Elk Lake outlet, respectively (table 5). The AME and RMSE values for total nitrogen in the hypolimnion for the south basin hole were 0.45 and $0.48 \mathrm{mg} / \mathrm{L}$, respectively (table 5). As with Lake Carlos, the measured data for Elk Lake indicate a relatively stable amount of total nitrogen in the lake, whereas the simulated results show a slow and steady decrease over the simulation period. As with Lake Carlos, this simulated decrease was likely because of the overall decay of the various organic matter pools and the decrease in total algal biomass. Total phosphorus concentrations were affected by the same factors as in Lake Carlos, with stable concentrations in the hypolimnion because of the offset between increasing orthophosphorus concentrations (fig. 37) and decreasing overall algal biomass (fig. 26). The AME values for total phosphorus ranged from 5 to $10 \mu \mathrm{g} / \mathrm{L}$, and RMSE values ranged from 6 to $16 \mu \mathrm{g} / \mathrm{L}$ (fig. 39; table 5).

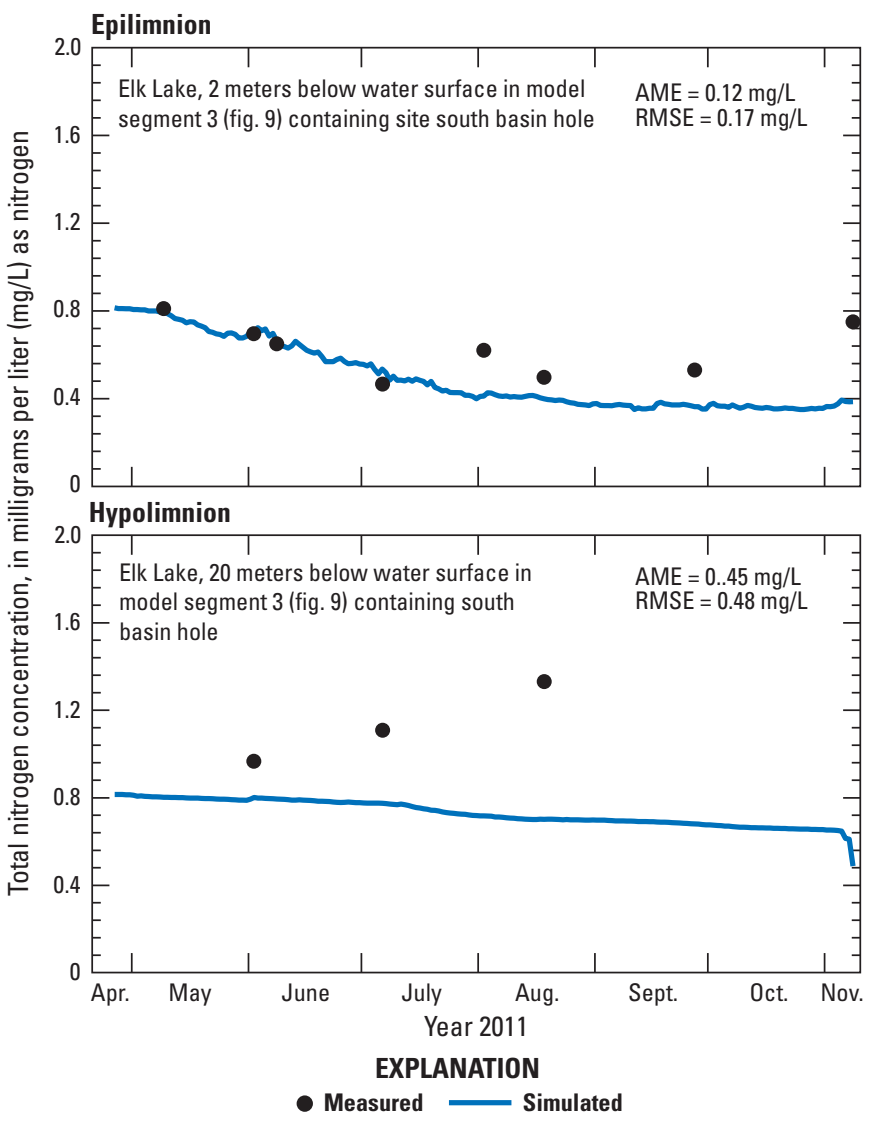

Figure 38. Simulated and measured total nitrogen concentrations for two depths at the south basin hole in Elk Lake, April 26, 2011, to November 8, 2011, with quantities of absolute mean error (AME) and root mean square error (RMSE).

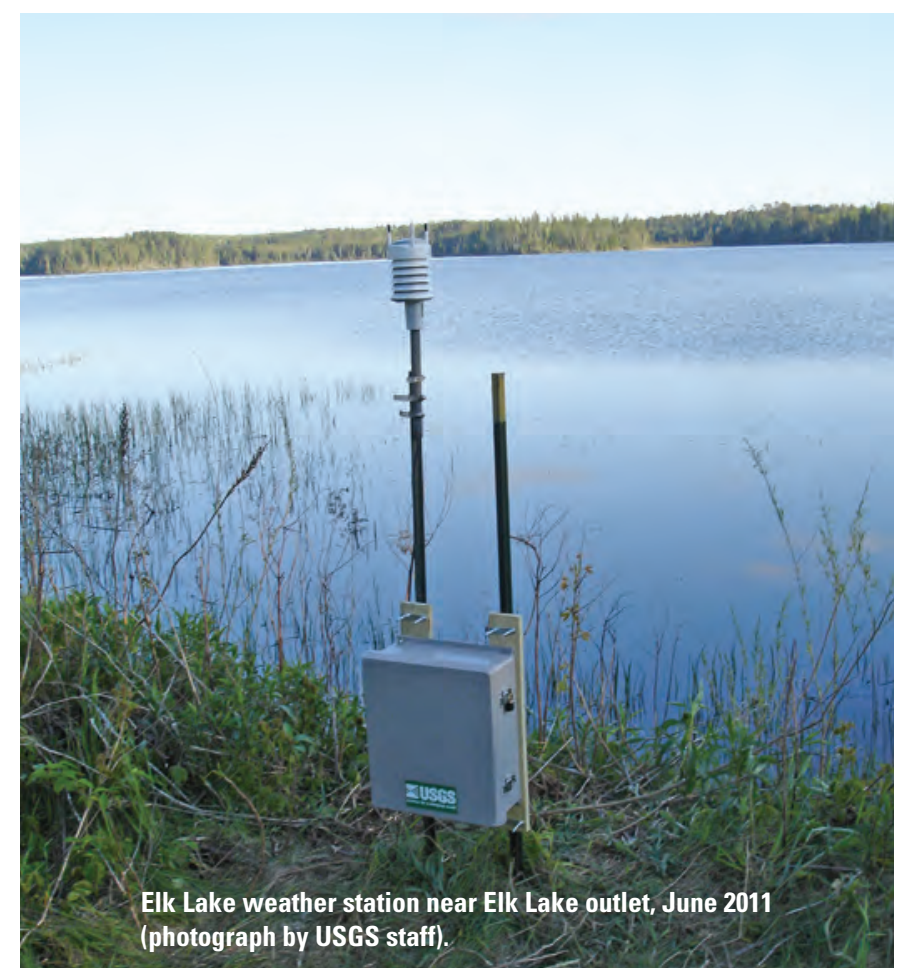




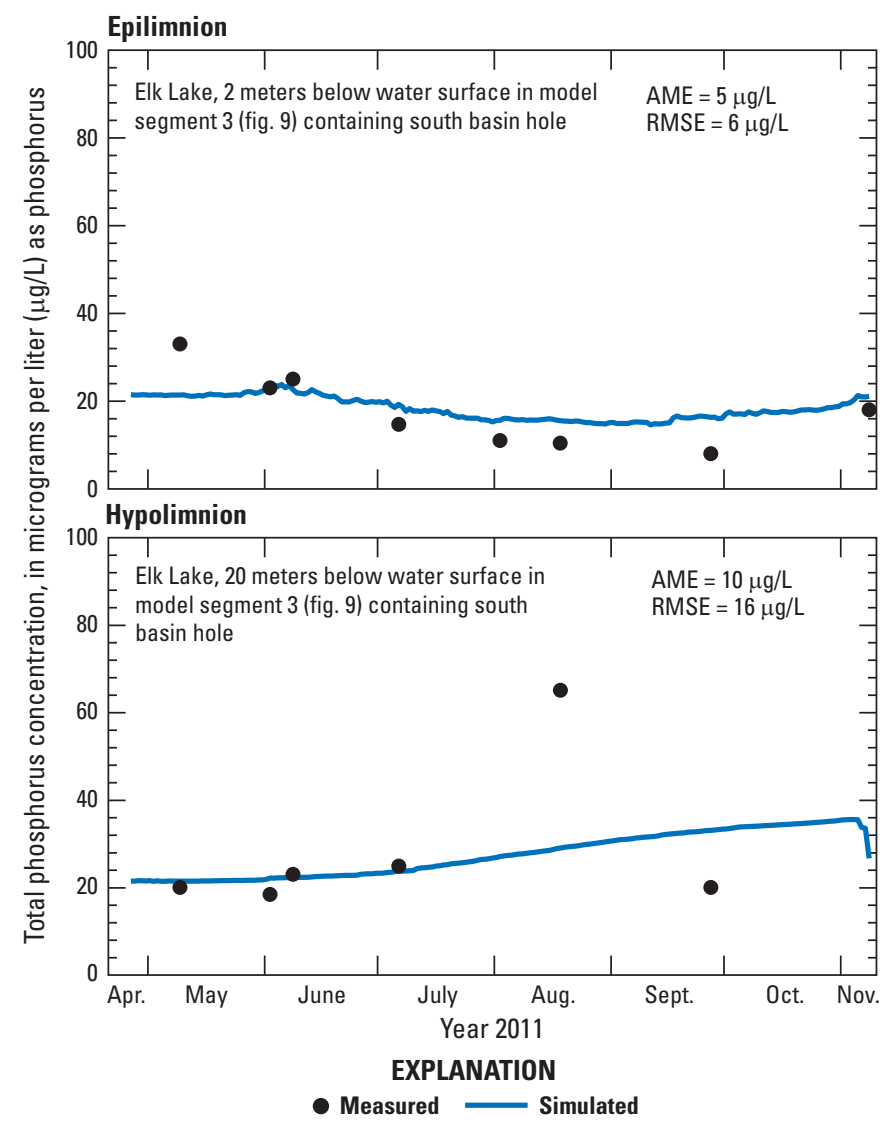

Figure 39. Simulated and measured total phosphorus concentrations for two depths at the south basin hole in Elk Lake, April 26, 2011, to November 8, 2011, with quantities of absolute mean error (AME) and root mean square error (RMSE)

\section{Trout Lake}

As in Lake Carlos and Elk Lake, ammonia and nitrate plus nitrite concentrations in Trout Lake were largely affected by the inflows and the lake hydrodynamics. The simulated and measured ammonia concentrations are shown for the north basin hole for depths of $1 \mathrm{~m}$ and $18 \mathrm{~m}$ below water surface (fig. 40). Of the three lakes, Trout Lake has the lowest overall amount of nutrients as indicated by the initial constituent concentrations (table 3). For example, the maximum measured ammonia concentrations in the epilimnion (1-m depth) were only about $0.01 \mathrm{mg} / \mathrm{L}$. Even in the hypolimnion (18-m depth), only a small concentration peak of $0.02 \mathrm{mg} / \mathrm{L}$ occurred for both the simulated results and measured data. For nitrate plus nitrite concentrations, the values were close to zero (fig. 41), indicating that nitrate was used almost as quickly as it was generated from ammonia nitrification or from inflows. The AME values for ammonia were low and ranged from $<0.01$ to $0.02 \mathrm{mg} / \mathrm{L}$, and the RMSE values ranged from $<0.01$ to $0.03 \mathrm{mg} / \mathrm{L}$ (table 5). The AME and RMSE values for nitrate plus nitrite ranged from $<0.01$ to $0.04 \mathrm{mg} / \mathrm{L}$ (table 5).
Orthophosphorus concentrations in Trout Lake were largely affected by the inflows and lake hydrodynamics. The concentration trends are similar between Trout Lake and Elk Lake, with fairly rapid algal uptake and replenishment by organic matter decay, inflows, or both. Similar to Elk Lake, orthophosphorus concentrations in the hypolimnion increased in the simulated results but not in the measured data. The AME and RMSE values for orthophosphorus were low overall because of low concentrations, and all were $<0.01 \mathrm{mg} / \mathrm{L}$ (fig. 42; table 5).

Simulated and measured concentrations are shown for total nitrogen (fig. 43) and total phosphorus (fig. 44). The AME values for total nitrogen in the epilimnion were 0.05 and $0.09 \mathrm{mg} / \mathrm{L}$ for the northeast basin hole and Trout Lake outlet, respectively, and RMSE values were 0.08 and $0.09 \mathrm{mg} / \mathrm{L}$ for the northeast basin hole and outlet, respectively (table 5). The AME and RMSE values for total nitrogen in the hypolimnion at the northeast basin hole were 0.07 and $0.08 \mathrm{mg} / \mathrm{L}$, respectively (fig. 43; table 5). The AME values for total phosphorus for the northeast basin hole and Trout Lake outlet ranged from 3 to $5 \mu \mathrm{g} / \mathrm{L}$, and RMSE values ranged from 4 to $6 \mu \mathrm{g} / \mathrm{L}$ (table 5).

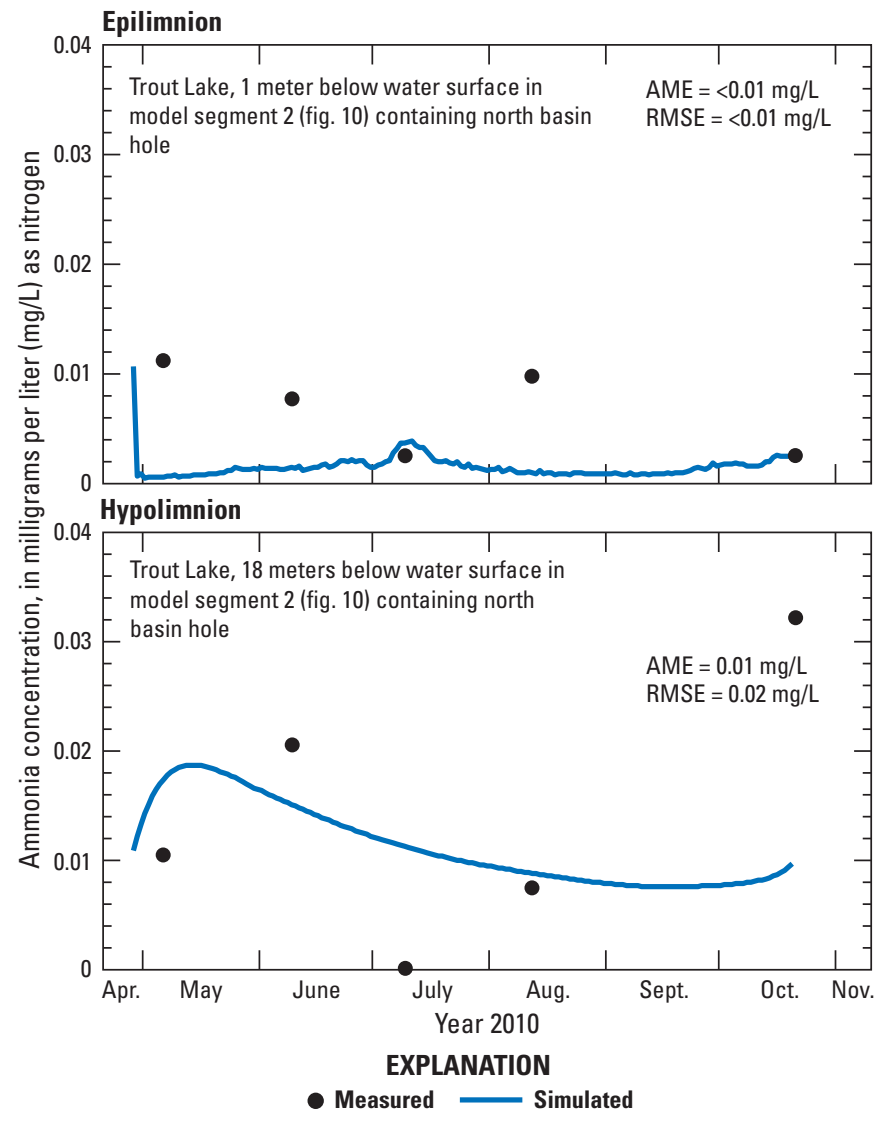

Figure 40. Simulated and measured ammonia concentrations for two depths at the north basin hole in Trout Lake, April 28, 2010, to 0 ctober 21, 2010, with quantities of absolute mean error (AME) and root mean square error (RMSE). 


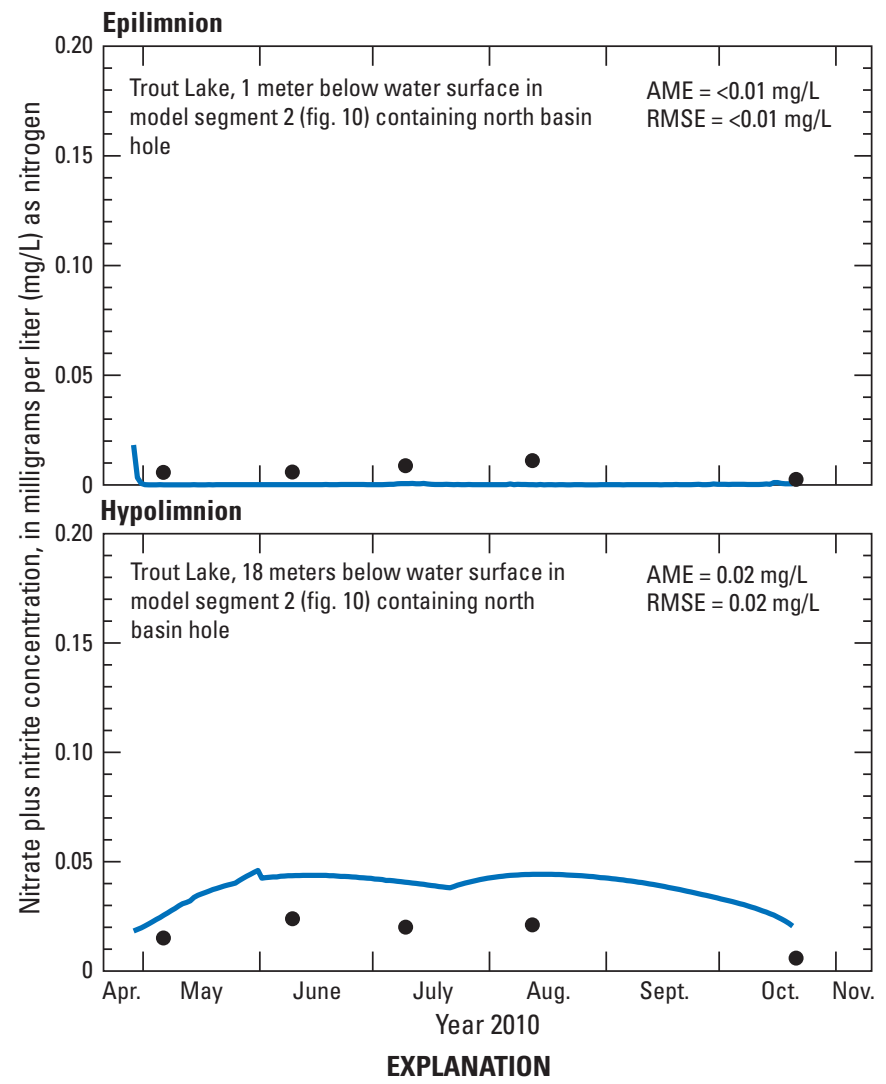

- Measured Simulated

Figure 41. Simulated and measured nitrate plus nitrite concentrations for two depths at the north basin hole in Trout Lake, April 28, 2010, to October 21, 2010, with quantities of absolute mean error (AME) and root mean square error (RMSE).

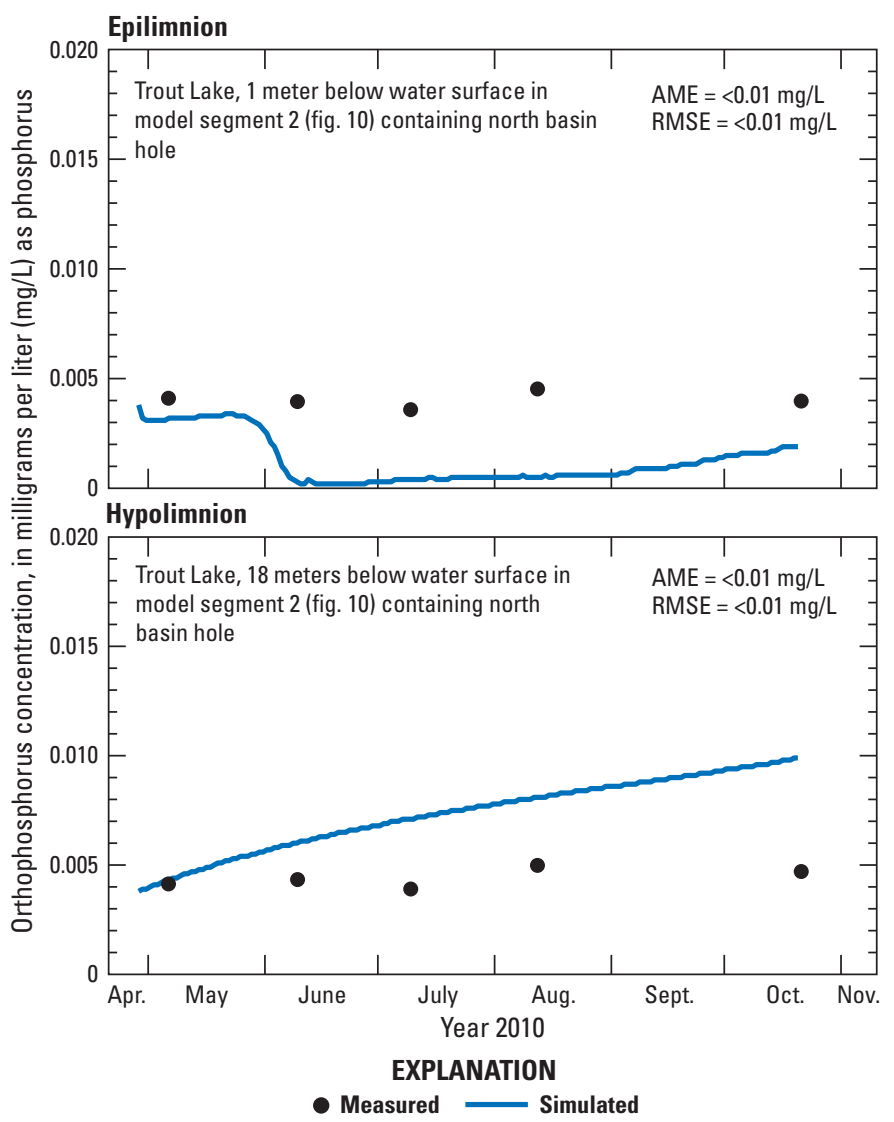

Figure 42. Simulated and measured orthophosphorus concentrations for two depths at the north basin hole in Trout Lake, April 28, 2010, to October 21, 2010, with quantities of absolute mean error (AME) and root mean square error (RMSE). 


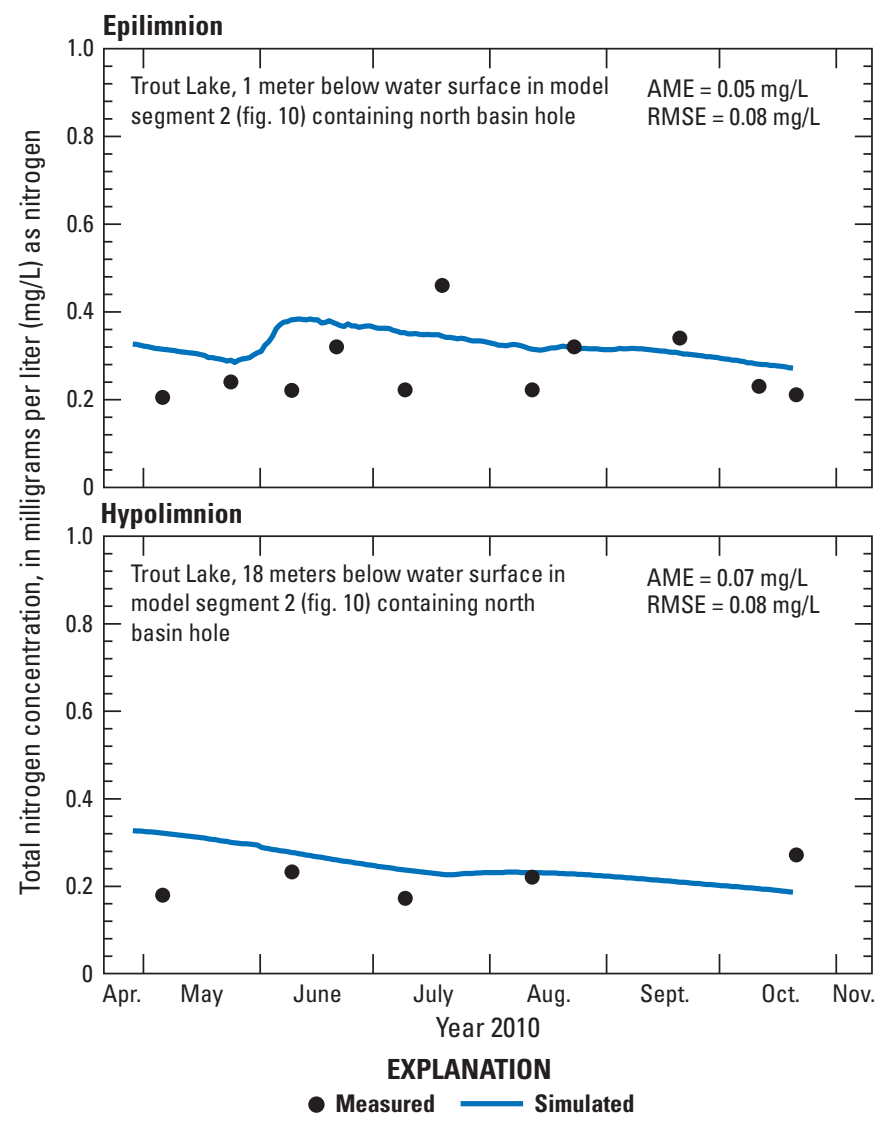

Figure 43. Simulated and measured total nitrogen concentrations for two depths at the north basin hole in Trout Lake, April 28, 2010, to October 21, 2010, with quantities of absolute mean error (AME) and root mean square error (RMSE).

\section{Model Validation}

The degree of fit between the simulated results and measured values was considered during the model validation using the same methods as the model calibration. The AME and RMSE values were used to evaluate the degree of fit between the simulated results and measured values. Emphasis in the model validation was placed on the temperature and DO results, with less emphasis placed on the water-quality

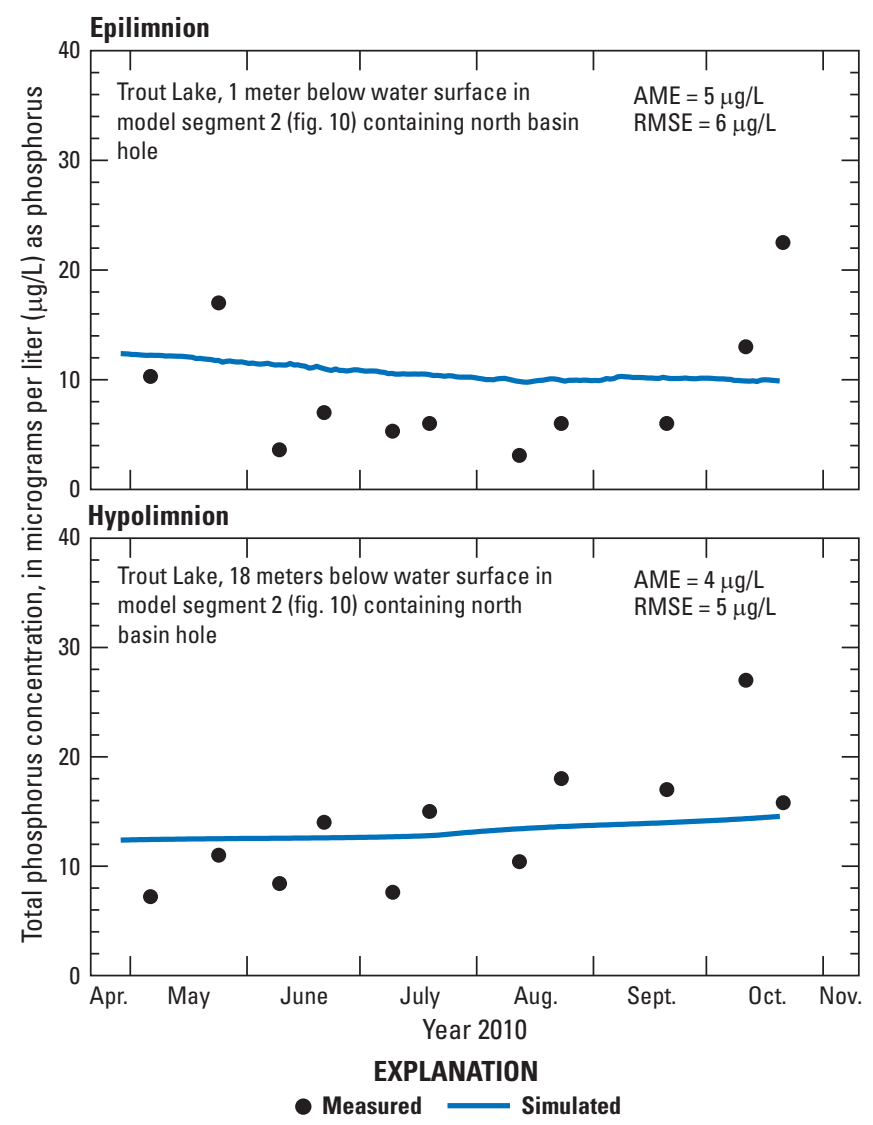

Figure 44. Simulated and measured total phosphorus concentrations for two depths at the north basin hole in Trout Lake, April 28, 2010, to October 21, 2010, with quantities of absolute mean error (AME) and root mean square error (RMSE).

results although some of the data are shown and described (table 6). For purposes of the model validation, only the initial conditions were altered (table 3 ). None of the approximately 130 parameters, as shown in table 4, were altered. One slight change from the model calibration was made during validation of the Elk Lake model, for which a constant wind sheltering coefficient of 50 percent was applied for the entire year because only Park Rapids meteorological data were available for the validation period. 


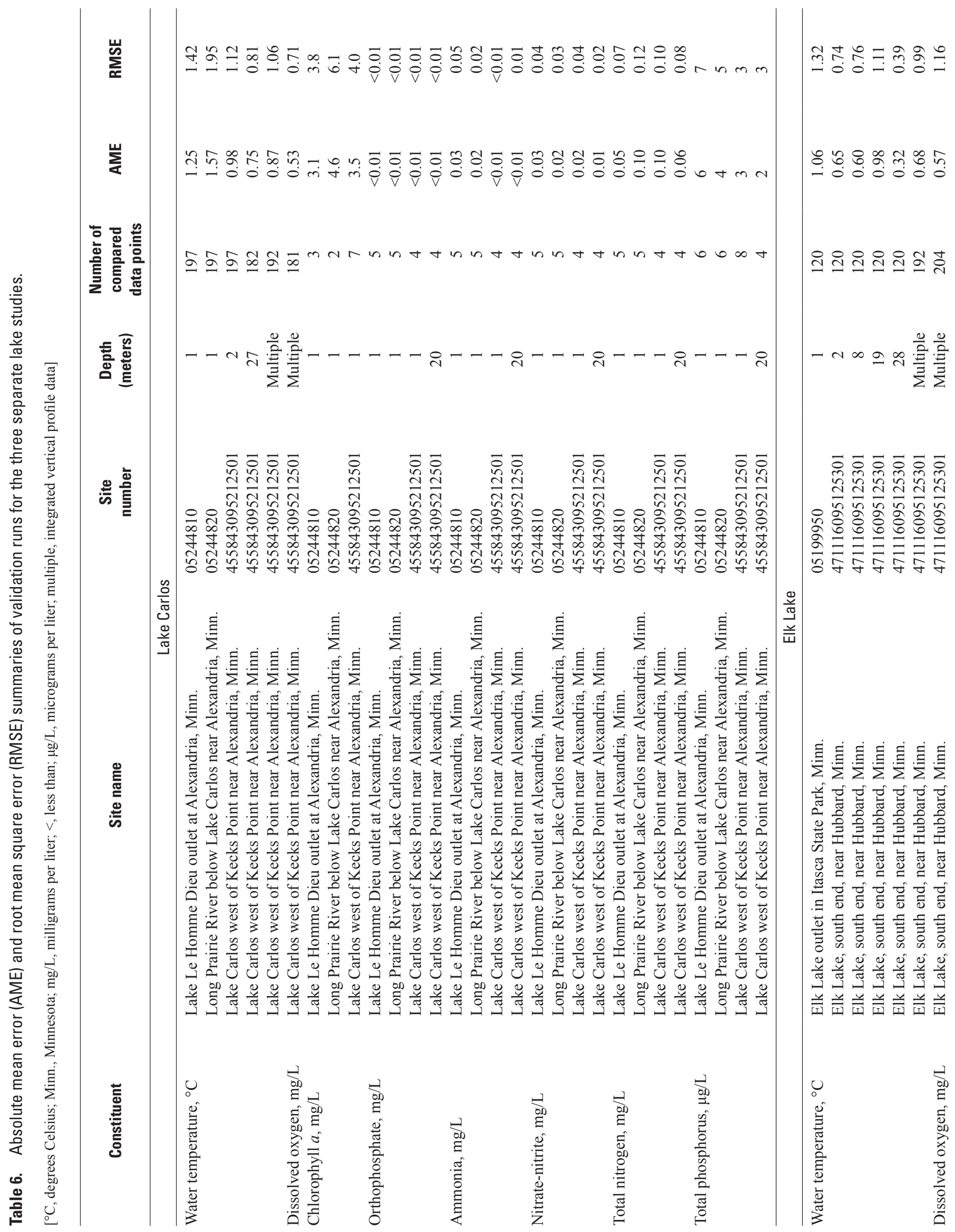




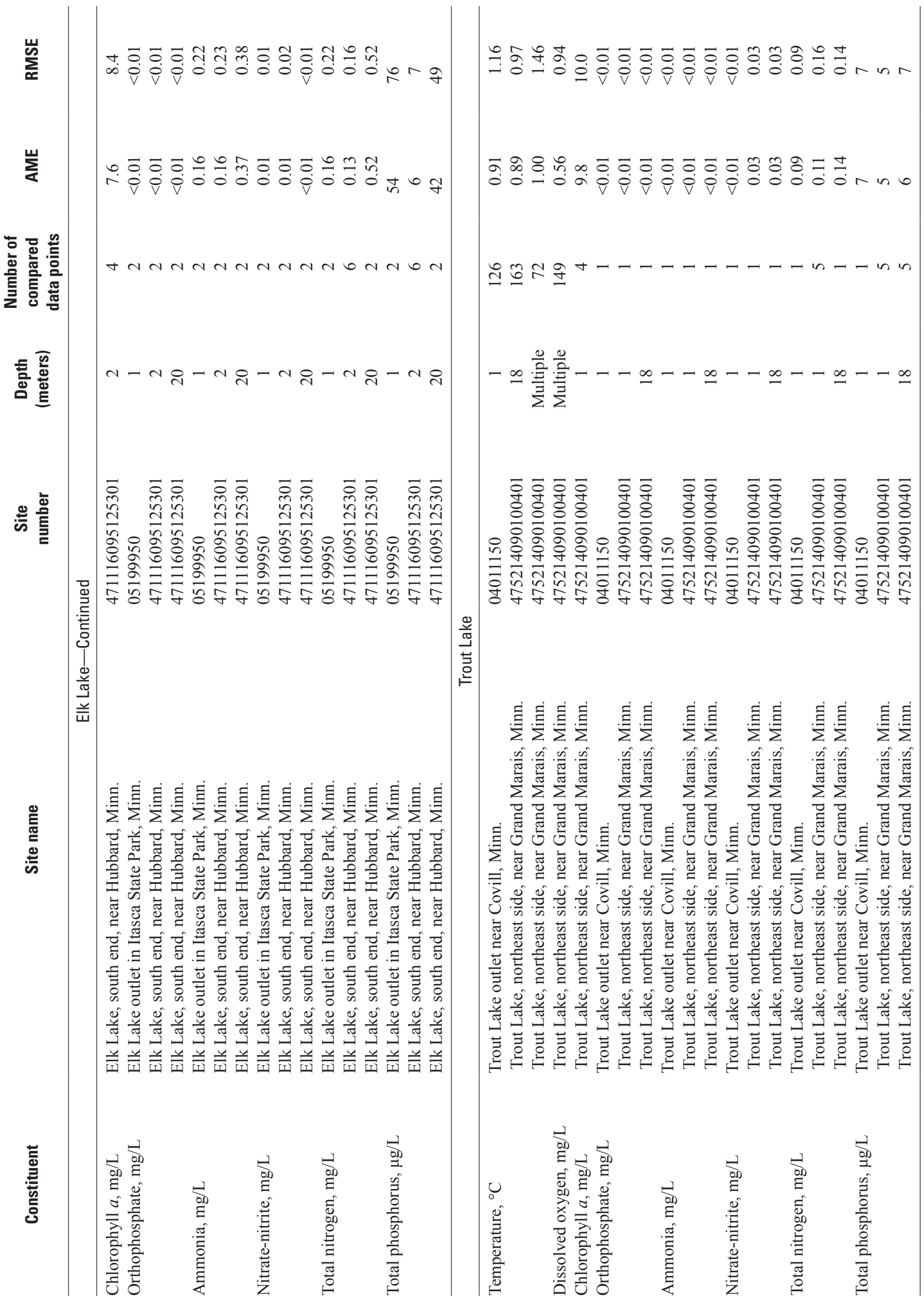




\section{Lake Carlos}

The validated model for Lake Carlos was run for the period March 14, 2011, to September 28, 2011. The ability of the model to predict the measured data was robust. As in the model calibration, the principal validation targets for temperature were the epilimnion (2-m depth) and hypolimnion (27-m depth) at Kecks Point (fig. 45; table 6). The AME and RMSE values were similar for the epilimnion and hypolimnion. As in the model calibration, the correlation between simulated and measured temperatures deviates most from late June through August, with simulated temperatures warmer than measured temperatures for the epilimnion and hypolimnion. However, the overall trends in temperature were represented by the simulated results.

Simulated water temperature also was compared to lake profile measurements of water temperature at Kecks Point. Similar to the continuous temporal results shown in figure 45, the ability of the model to predict water temperature was consistent throughout the profile (fig. 46). The AME and RMSE values generally were equal to or less than $1.2{ }^{\circ} \mathrm{C}$ and the model approximated the location and slope of the thermocline. On several dates, only four measured values were available from the continuous sonde data, producing a positive bias in the AME and RMSE values. In particular, August 18, 2011, had the highest AME and RMSE values, despite the simulated temperature profile for this date reflecting the overall decreasing measured temperatures.

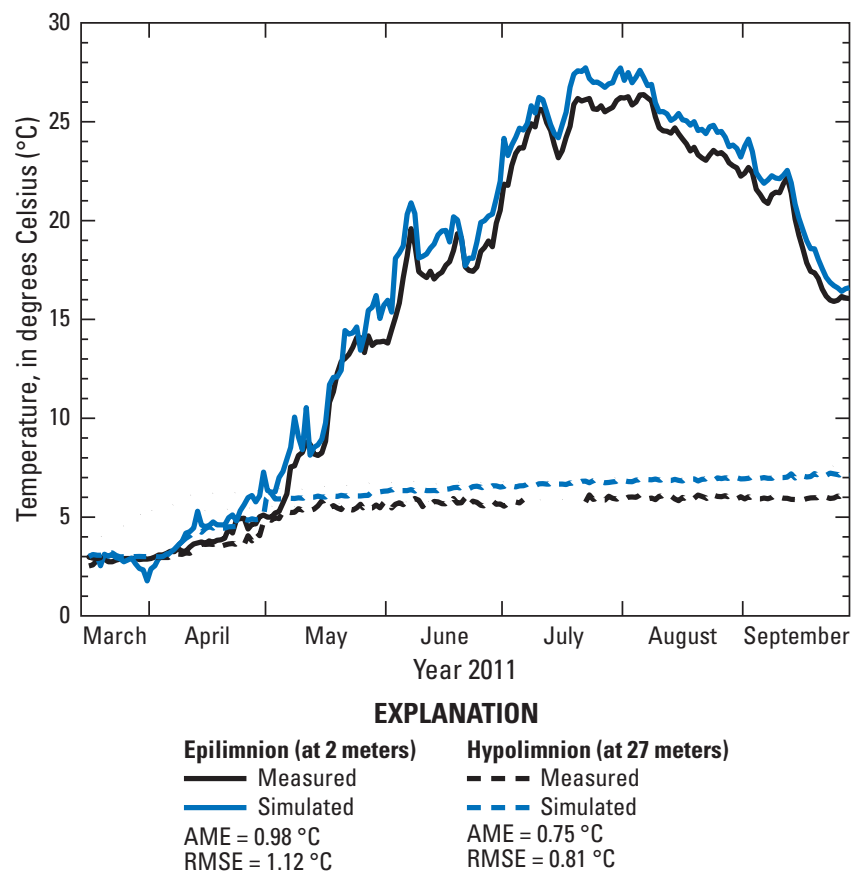

Figure 45. Simulated and measured water temperature for the epilimnion and hypolimnion at Kecks Point in Lake Carlos, March 14, 2011, to September 28, 2011, with quantities of absolute mean error (AME) and root mean square error (RMSE).
Overall, the simulated DO concentrations compared better to the measured concentrations for the validation run (fig. 47) than the initial model calibration (fig. 20). All of the AME and RMSE values were less than $1 \mathrm{mg} / \mathrm{L}$, with all of the major trends in the measured profile simulated including the small increase in DO at depth in the later summer months (July 21, 2011, and August 4, 2011).

For the validation run for chlorophyll $a$ concentrations, three locations are shown in figure 48 , including the simulated results ( $1 \mathrm{~m}$ below the water surface) for the model segment adjacent to the Lake Le Homme Dieu outlet (segment 5, fig. 8), the model segment containing Kecks Point (segment 18, fig. 8), and the model segment adjacent to the Long Prairie River (segment 22, fig. 8). Similar to the 2010 model calibration year, measured data for the validation run primarily were collected in the surface layer at Kecks Point with a few ancillary measurements at the other two locations. Overall, the simulated results were a fairly good approximation of the measured data, with AME and RMSE values of 3.5 and $4.0 \mu \mathrm{g} / \mathrm{L}$, respectively, in the model segment containing Kecks Point (table 6). For the model validation, the simulated results consistently overpredicted the chlorophyll $a$ concentration, which would in turn affect the algal composition of the lake.

The simulated and measured concentrations for total nitrogen (fig. 49) and total phosphorus (fig. 50) are shown for the same three monitoring locations at $1-\mathrm{m}$ depth, with the addition of results for 20-m depth for Kecks Point. For three of the four locations, the simulated results for total nitrogen compared better with measured data for the model validation (fig. 49; table 6) than for the model calibration (fig. 33; table 5). The AME and RMSE values were as low as 0.05 and $0.07 \mathrm{mg} / \mathrm{L}$, respectively, for the model segment adjacent to the Lake Le Homme Dieu outlet. The highest AME and RMSE values of 0.10 and $0.12 \mathrm{mg} / \mathrm{L}$, respectively, for total nitrogen were in the model section adjacent to the Long Prairie River (fig. 49). In contrast to total nitrogen, simulated results for total phosphorus compared better with measured data for the initial model calibration (fig. 34; table 5) than for the model validation (fig. 50; table 6); however, the simulated results for the validation still compared well to the measured data. In general, the simulated results underpredicted the total phosphorus concentrations particularly in the segments adjacent to the Lake Le Homme Dieu outlet and the Long Prairie River (fig. 50). The AME for total phosphorus across the four locations ranged from 2 to $6 \mu \mathrm{g} / \mathrm{L}$, and the RMSE for total phosphorus ranged from 3 to $7 \mu \mathrm{g} / \mathrm{L}$. 

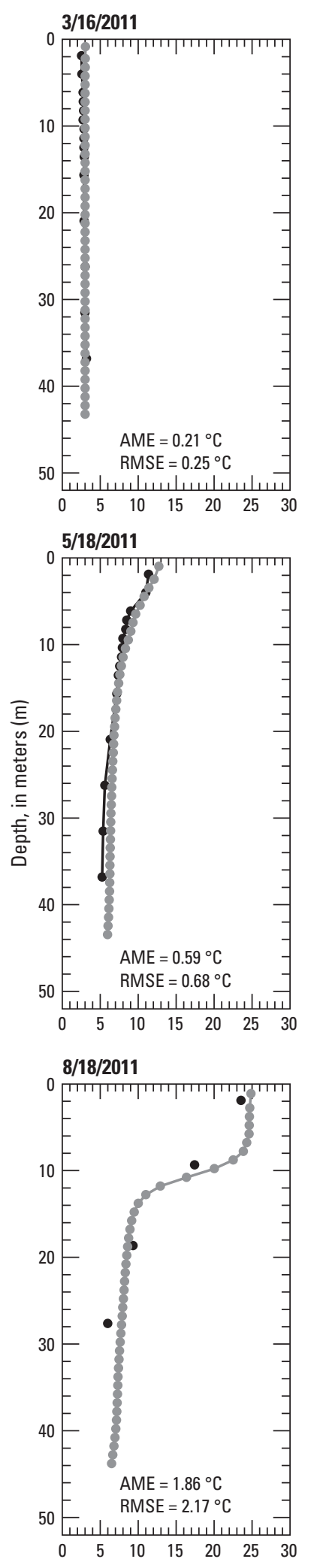

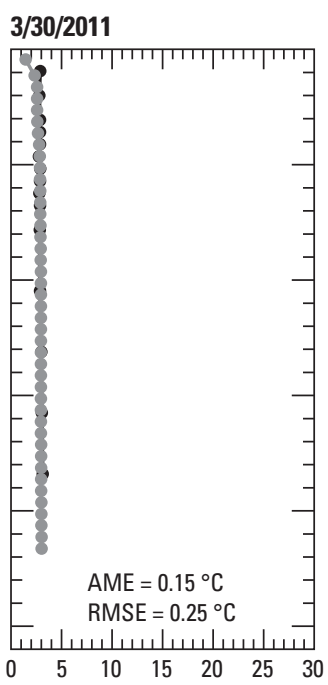

$6 / 8 / 2011$

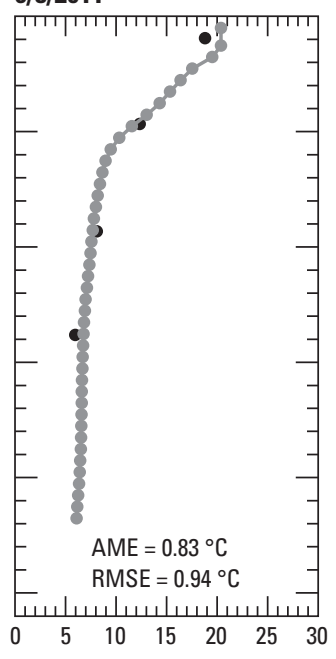

9/3/2011

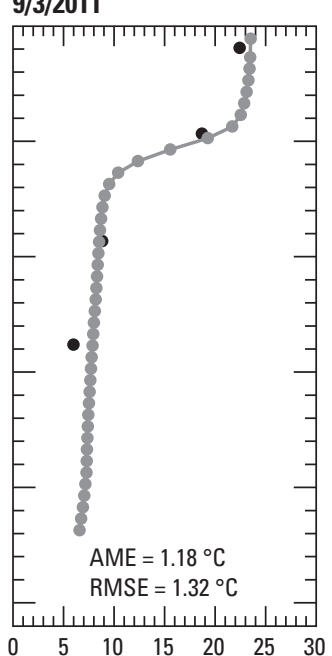

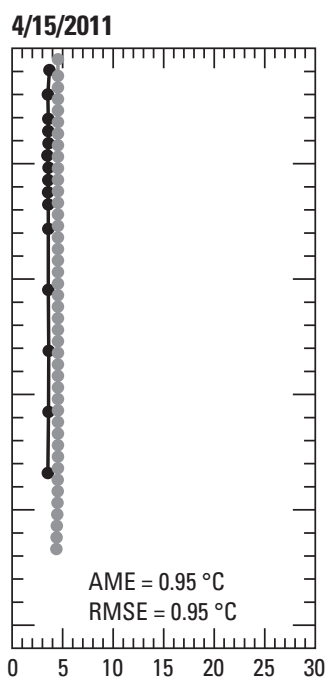

$6 / 14 / 2011$

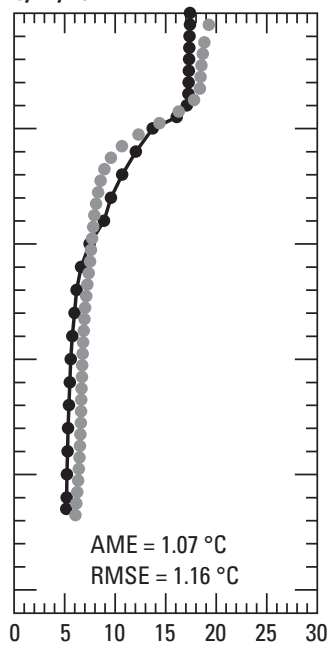

9/27/2011

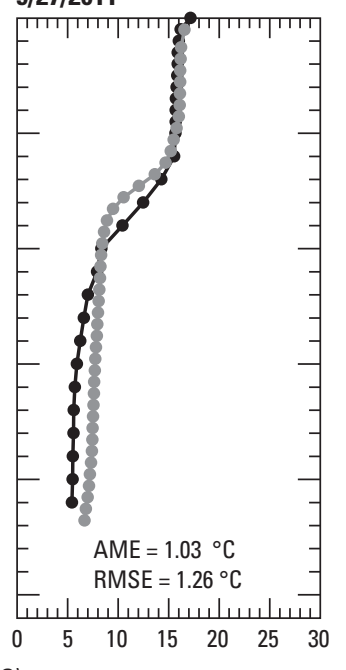

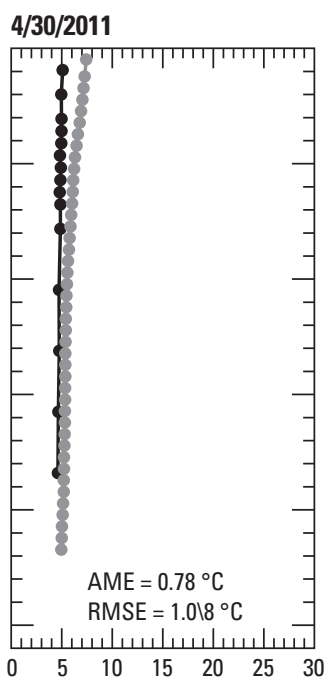

5/10/2011

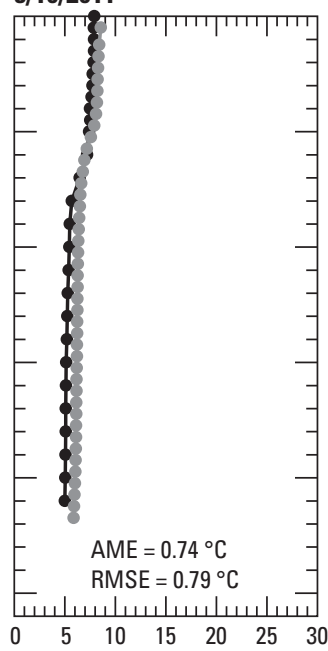

$7 / 21 / 2011$

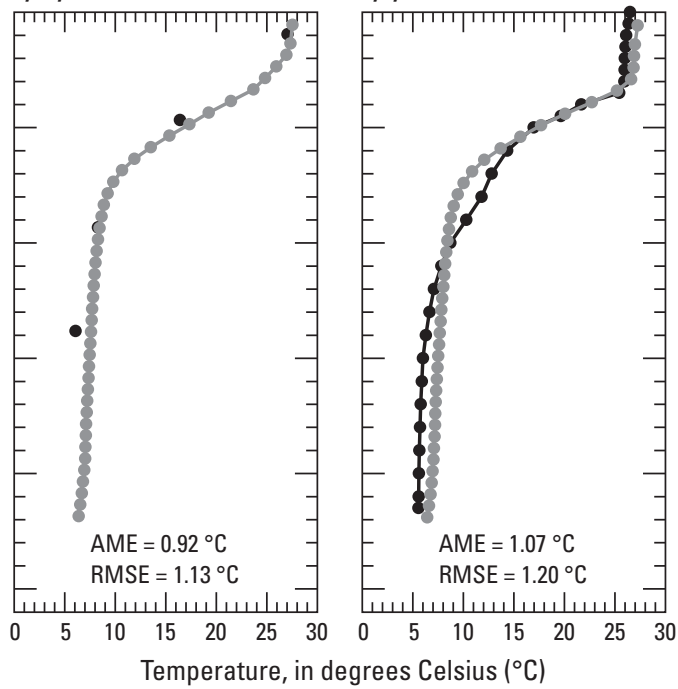

EXPLANATION

Temperature, in degrees Celsius $\left({ }^{\circ} \mathrm{C}\right)$

Figure 46. Simulated and measured water temperature at Kecks Point in Lake Carlos for 13 dates in 2011, with quantities of absolute mean error (AME) and root mean square error (RMSE). 


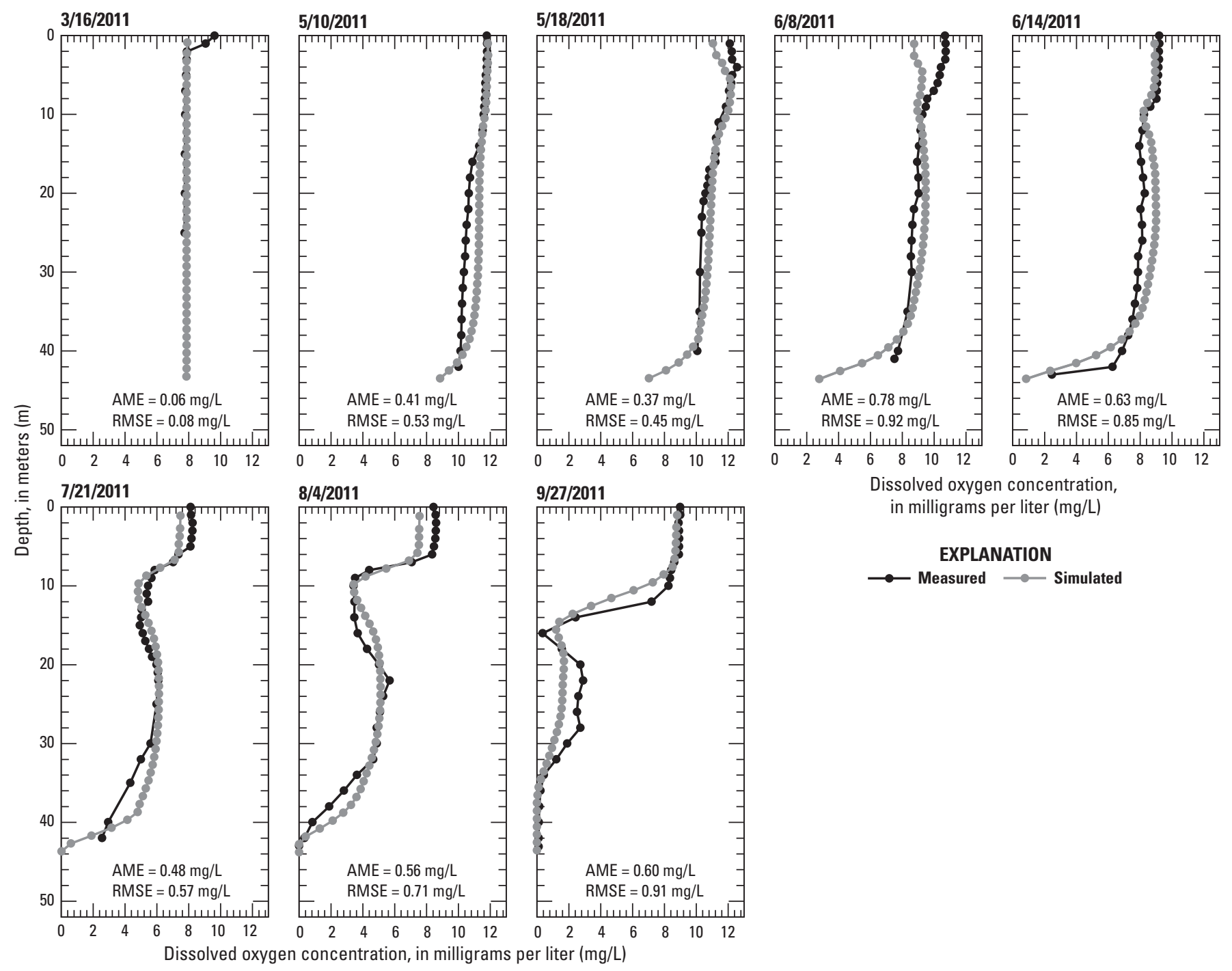

Figure 47. Simulated and measured dissolved oxygen concentration at Kecks Point in Lake Carlos for eight dates in 2011, with quantities of absolute mean error (AME) and root mean square error (RMSE). 


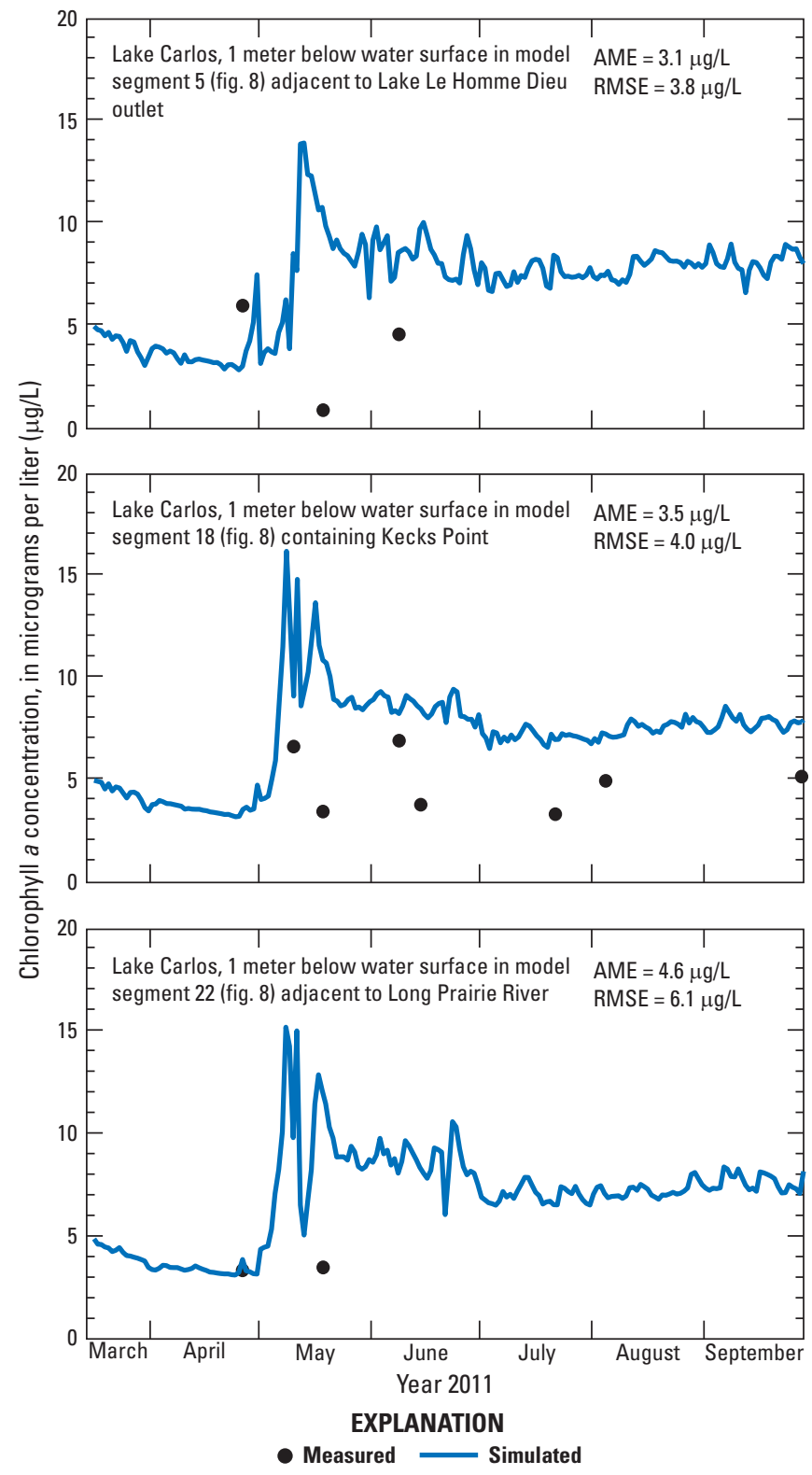

Figure 48. Simulated and measured chlorophyll a concentrations for three model segments for Lake Carlos, March 14, 2011, to September 28, 2011, with quantities of absolute mean error (AME) and root mean square error (RMSE).
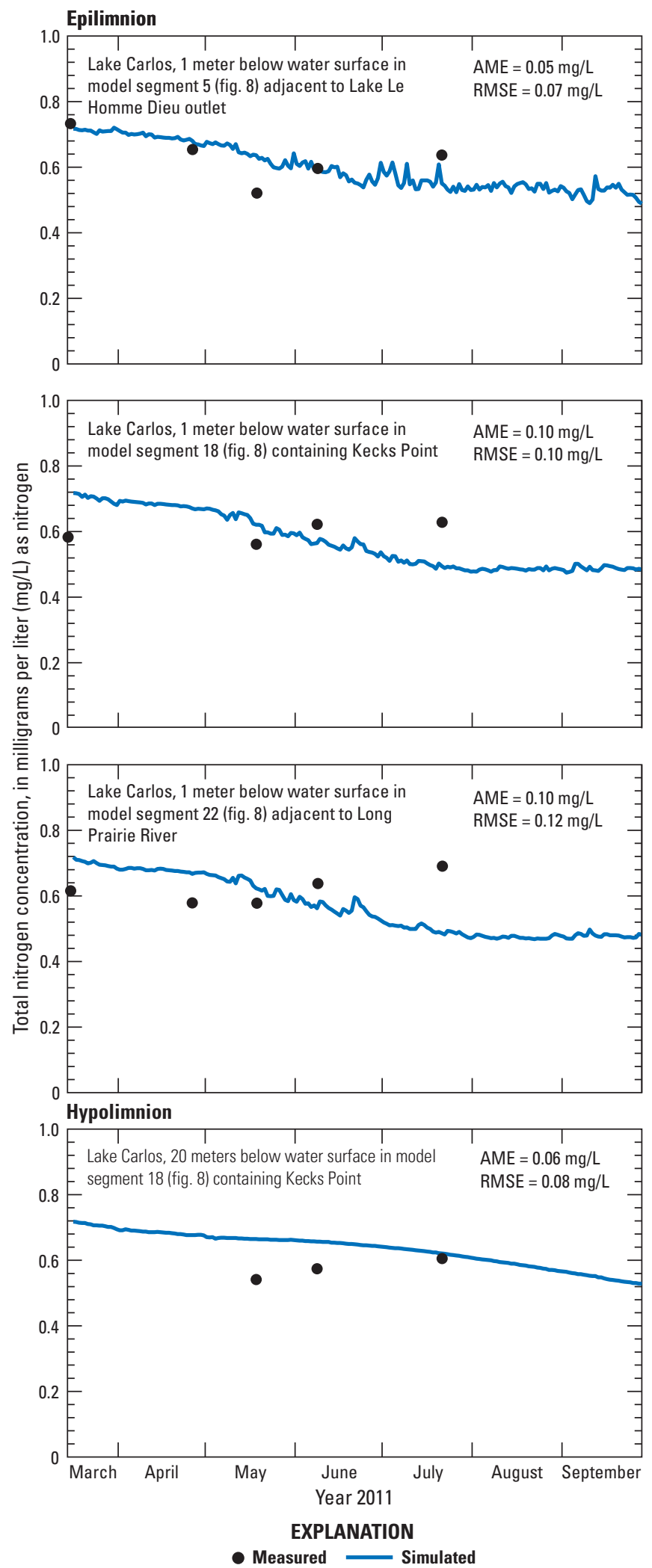

Figure 49. Simulated and measured total nitrogen concentrations for three epilimnetic model segments (segments 5,18 , and 22) and a hypolimnetic model segment (segment 18) for Lake Carlos, March 14, 2011, to September 28, 2011, with quantities of absolute mean error (AME) and root mean square error (RMSE). 

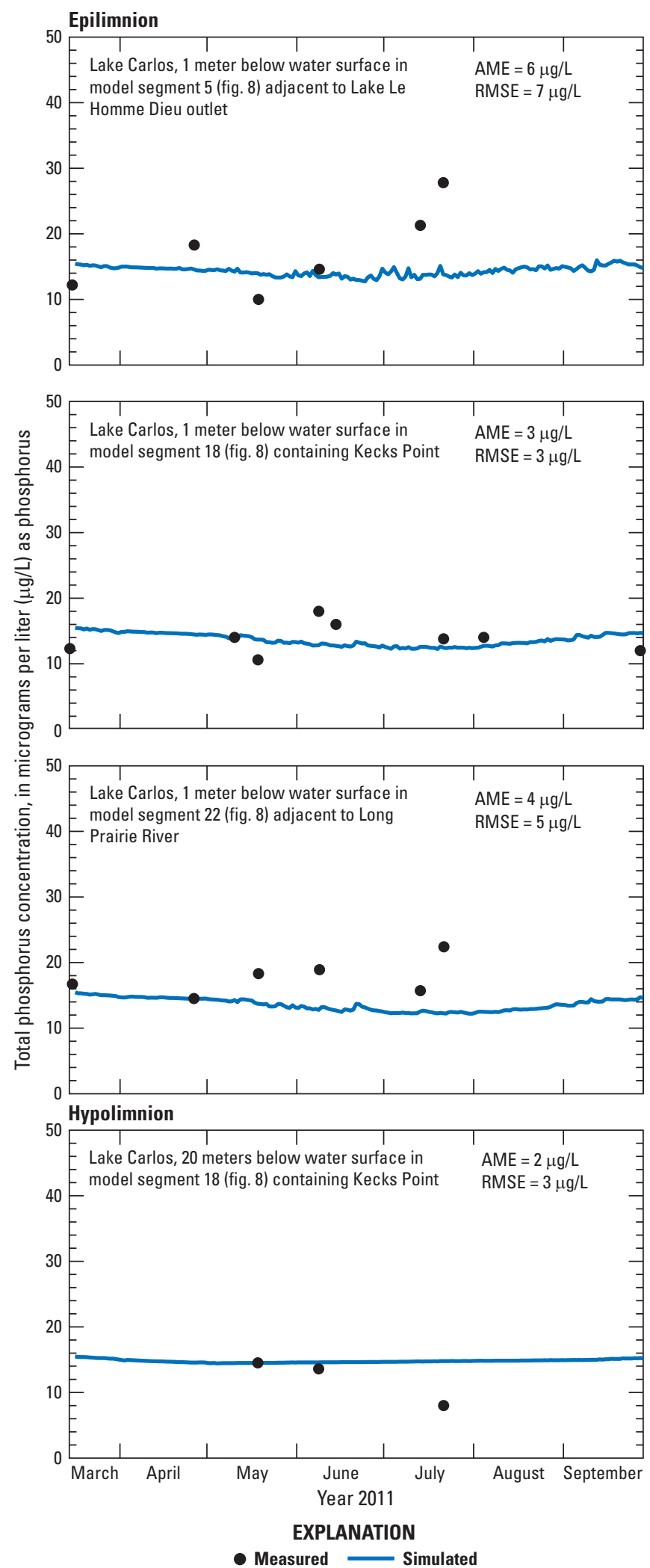

Figure 50. Simulated and measured total phosphorus concentrations for three epilimnetic model segments (segments 5,18 , and 22) and a hypolimnetic model segment (segment 18) for Lake Carlos, March 14, 2011, to September 28, 2011, with quantities of absolute mean error (AME) and root mean square error (RMSE).

\section{Elk Lake}

The validated model for Elk Lake was run for the period July 13, 2010, to November 9, 2010. Because of the timing of transducer installation, the abridged period was the longest period available for model validation outside of the model calibration year in 2011; however, this period provided a timeframe to evaluate the robustness of the model under different meteorological and hydrologic conditions.

As in the model calibration, the principal validation targets for temperature were two locations in the epilimnion (2and 8-m depths, respectively) and two locations in the hypolimnion (19- and 28-m depths, respectively) at the south basin hole (fig. 51; table 6). Simulated results for all four depths matched measured data reasonably well, with better comparisons for three of the four depths for the model validation than for the model calibration. The shallowest location (2-m depth) had AME and RMSE values of $0.65^{\circ} \mathrm{C}$ and $0.74{ }^{\circ} \mathrm{C}$, respectively, very similar to values for the model calibration (fig. 16; table 5). The other epilimnion location (8-m depth) had AME and RMSE values of $0.60{ }^{\circ} \mathrm{C}$ and $0.76^{\circ} \mathrm{C}$, respectively, which also indicated a better match over the model calibration. At the 19-m depth, the AME and RMSE values of $0.98^{\circ} \mathrm{C}$ and $1.1{ }^{\circ} \mathrm{C}$, respectively, were the highest of the four locations. At the 28-m depth, the AME and RMSE values were $0.32{ }^{\circ} \mathrm{C}$ and $0.39^{\circ} \mathrm{C}$, respectively. The slightly higher AME and RMSE values at the 19-m depth were caused by the offset in temperature that occurred at depth because of the mismatch in timing of lake mixing by the CE-QUAL-W2 model. However, this offset was not as dramatic as in the 2011 model calibration year.

Simulated water temperatures in Elk Lake also were compared to lake profile data at the south basin hole for a total of 12 dates (fig. 52). The model consistently attained AME and RMSE values of less than $1.0^{\circ} \mathrm{C}$ for most dates. As in the model calibration, the simulated thermocline for the validation run matched the location and slope of the measured thermocline. The only discrepancy between the simulated and measured thermocline was the early stages of lake mixing being slightly mistimed (October 26, 2010).

As in the model calibration, the principal calibration targets for $\mathrm{DO}$ in the model validation were the lake profile data at the south basin hole. A total of 10 dates are shown in figure 53. Overall, agreement between simulated and measured DO concentrations was better for the model validation than model calibration (fig. 21). The AME for DO for the 10 dates ranged from 0.19 to $0.87 \mathrm{mg} / \mathrm{L}$, and the RMSE ranged from 0.50 to $1.62 \mathrm{mg} / \mathrm{L}$.

As in the model calibration, chlorophyll $a$ concentrations were used for the model validation to interpret the overall magnitude or size of the algal communities. With measured data only available for the shallow layer at $2 \mathrm{~m}$ below the water surface, the simulated chlorophyll $a$ concentrations were consistently overestimated compared to the measured data (fig. 54; table 6). The simulated and measured concentrations for total nitrogen (fig. 55) and total phosphorus (fig. 56) are 

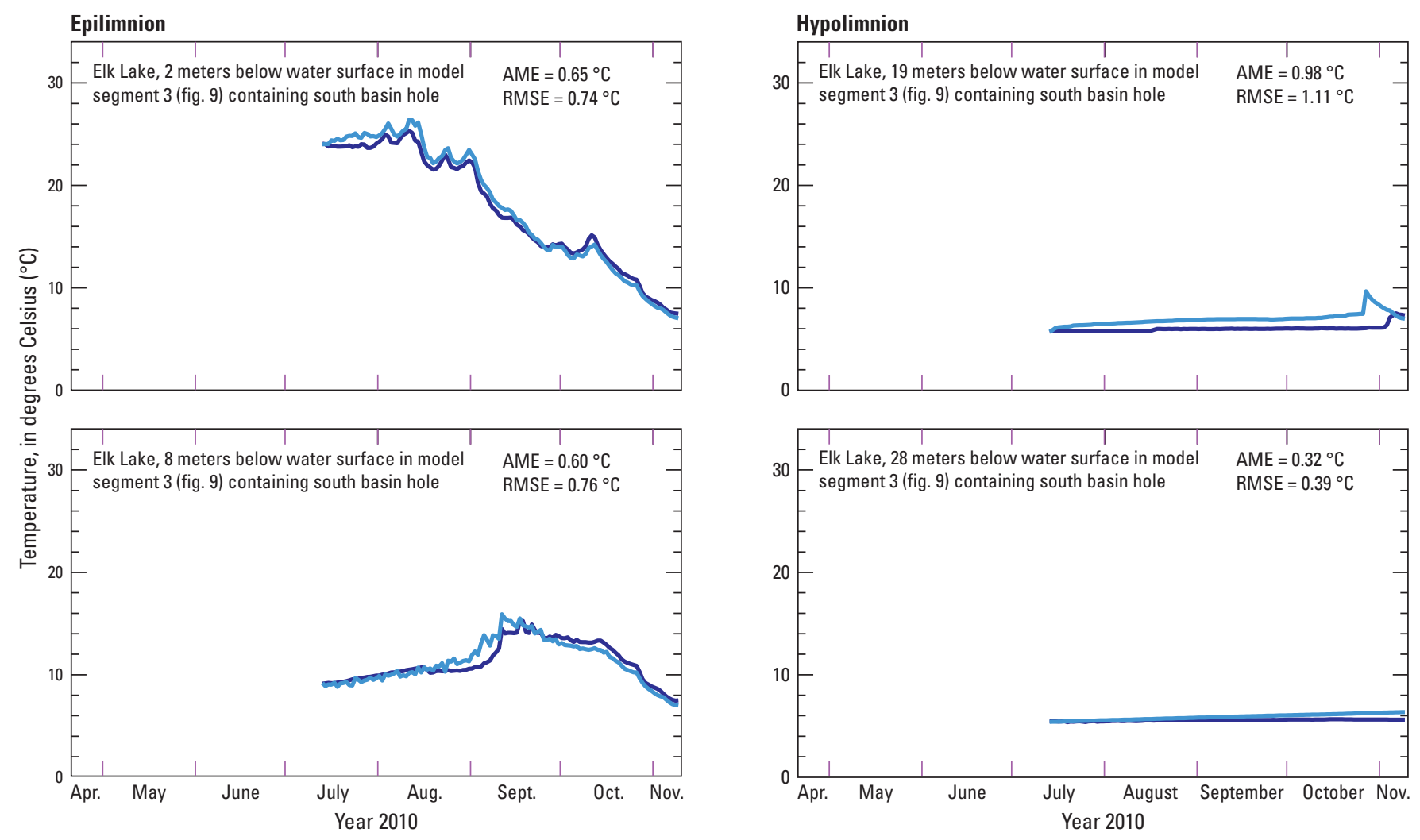

EXPLANATION

Figure 51. Simulated and measured water temperature for the epilimnion and hypolimnion at the south basin hole in Elk Lake, July 13, 2010, to November 9, 2010, with quantities of absolute mean error (AME) and root mean square error (RMSE).

shown for the same monitoring locations as for chlorophyll $a$ concentrations. For both total nitrogen and total phosphorus concentrations, the model achieved better results for the epilimnion (2-m depth) than for the hypolimnion (20-m depth). The AME values for the epilimnion for total nitrogen and total phosphorus were $0.13 \mathrm{mg} / \mathrm{L}$ and $6 \mu \mathrm{g} / \mathrm{L}$, respectively. The RMSE values for total nitrogen and total phosphorus were $0.16 \mathrm{mg} / \mathrm{L}$ and $7 \mu \mathrm{g} / \mathrm{L}$, respectively. For the hypolimnion (20-m depth), the model underestimated the concentrations of both constituents. This understimation indicates that the model needs additional refinement for predicting total nitrogen and total phosphorus concentrations in the hypolimnion. One possible mechanism to explain the hypolimnion values could be the missing zooplankton dynamics. For example, a shift from rotifers to copepods could result in a larger export of nitrogen and phosphorus to the hypolimnion, as the fecal pellets expelled by the copepods would likely export more nitrogen and phosphorus to the hypolimnion. The AME values for the hypolimnion for total nitrogen and total phosphorus were $0.52 \mathrm{mg} / \mathrm{L}$ and $42 \mu \mathrm{g} / \mathrm{L}$, respectively. The RMSE values for total nitrogen and total phosphorus were $0.52 \mathrm{mg} / \mathrm{L}$ and $49 \mu \mathrm{g} / \mathrm{L}$, respectively.

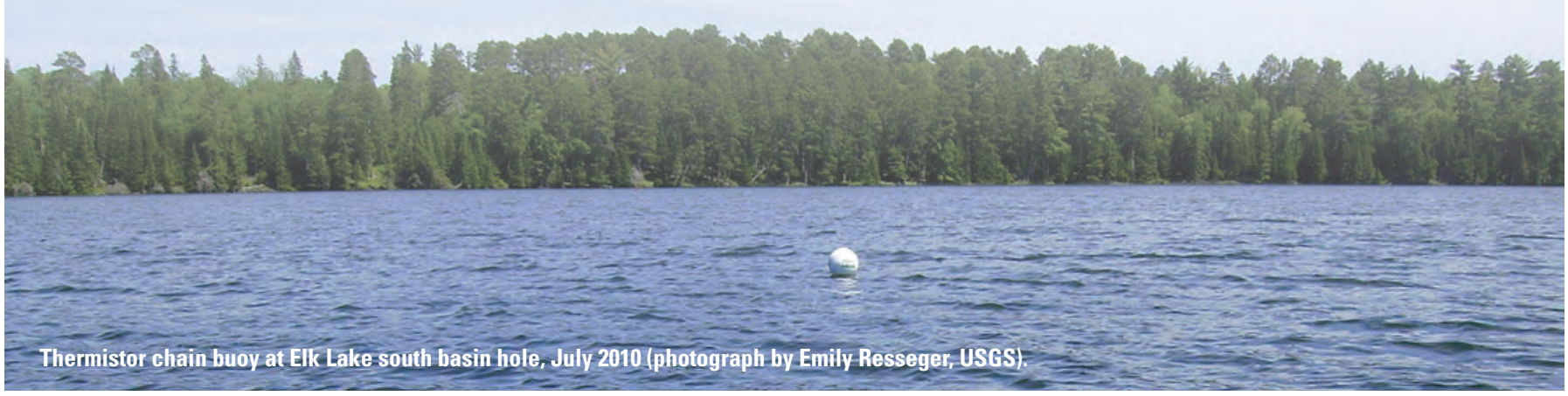



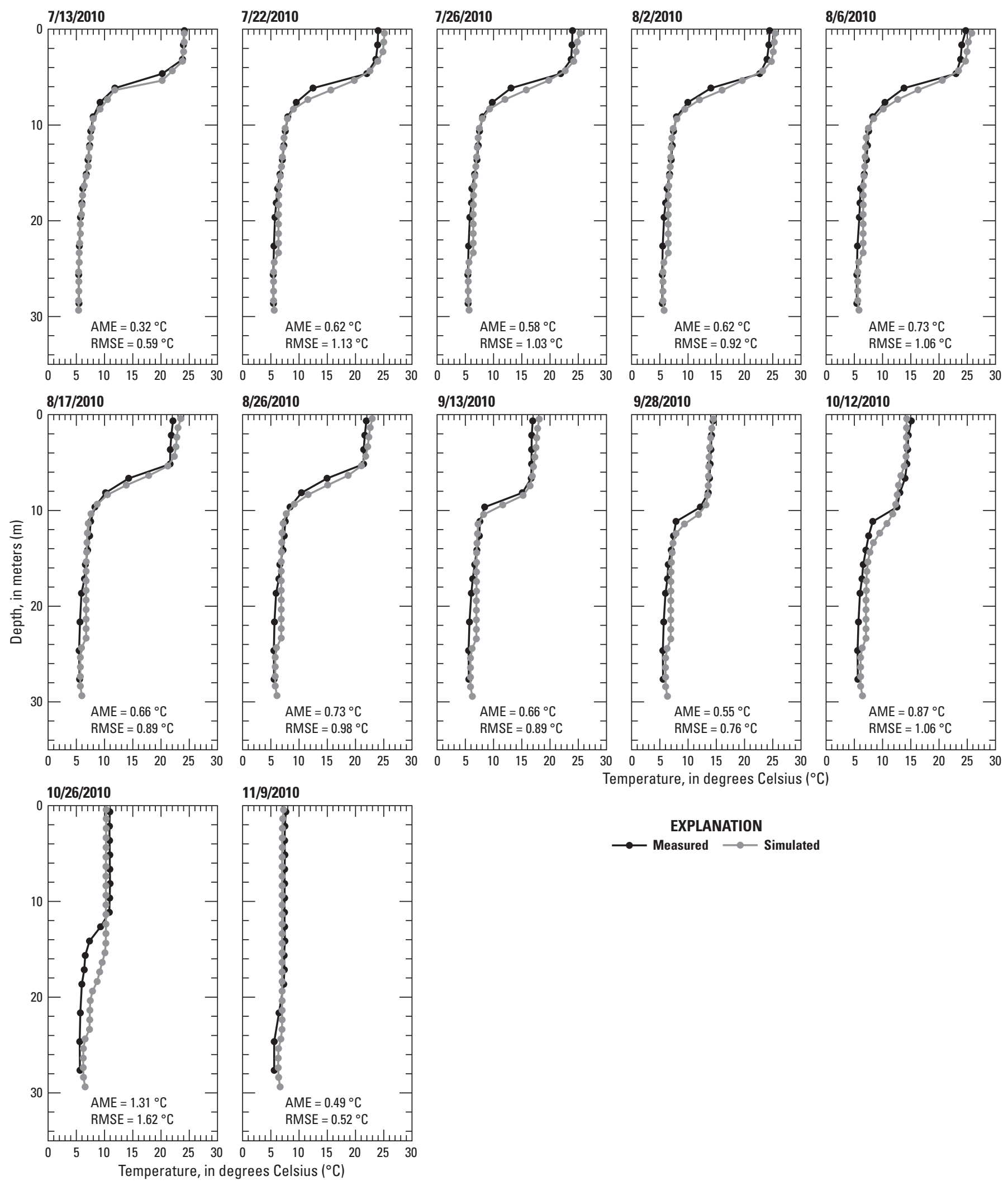

EXPLANATION

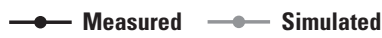

Figure 52. Simulated and measured water temperature at the south basin hole in Elk Lake for 12 dates in 2010, with quantities of absolute mean error (AME) and root mean square error (RMSE). 

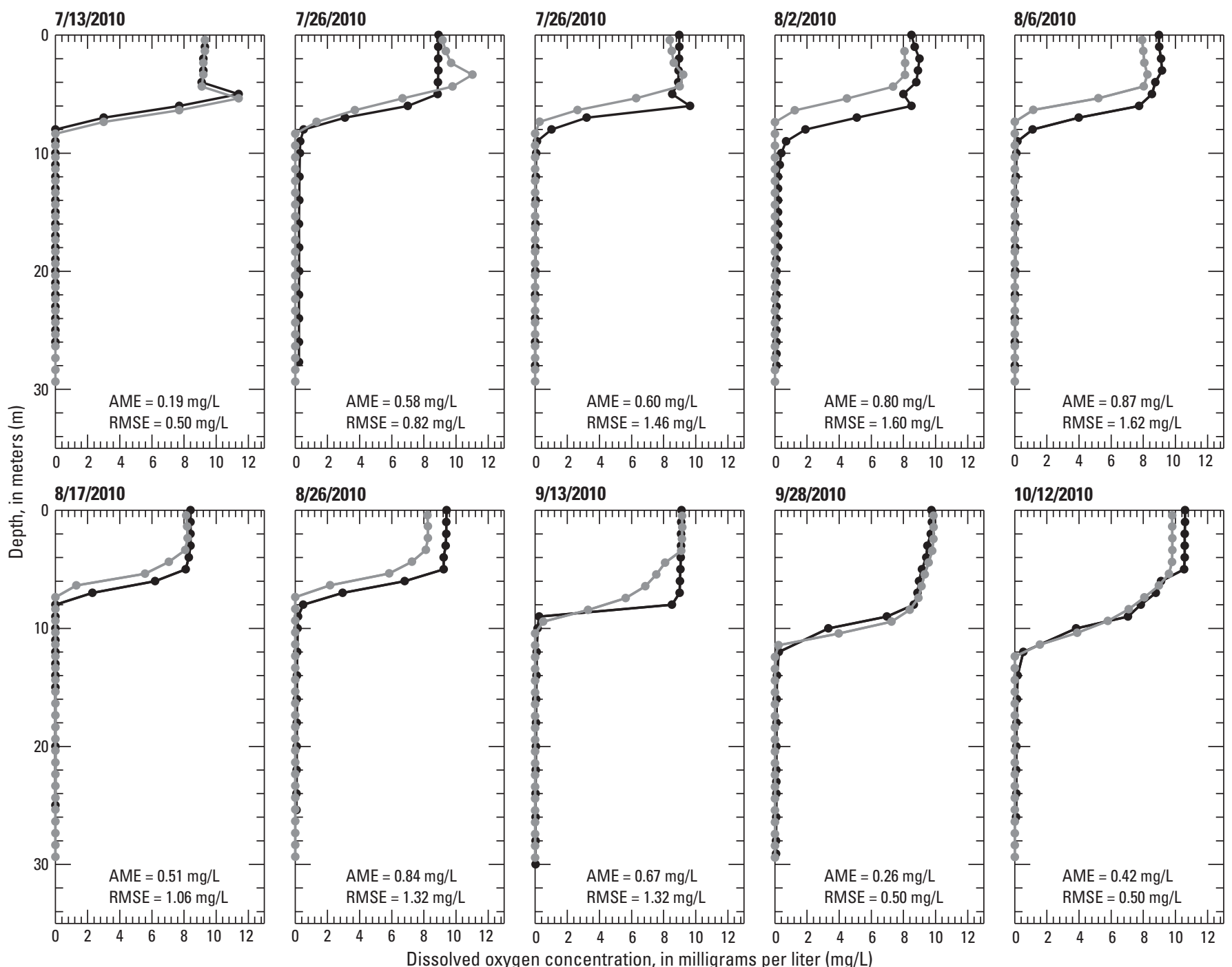

EXPLANATION

$\longrightarrow$ Measured $\longrightarrow$ Simulated

Figure 53. Simulated and measured dissolved oxygen concentration at the south basin hole in Elk Lake for 10 dates in 2010, with quantities of absolute mean error (AME) and root mean square error (RMSE). 


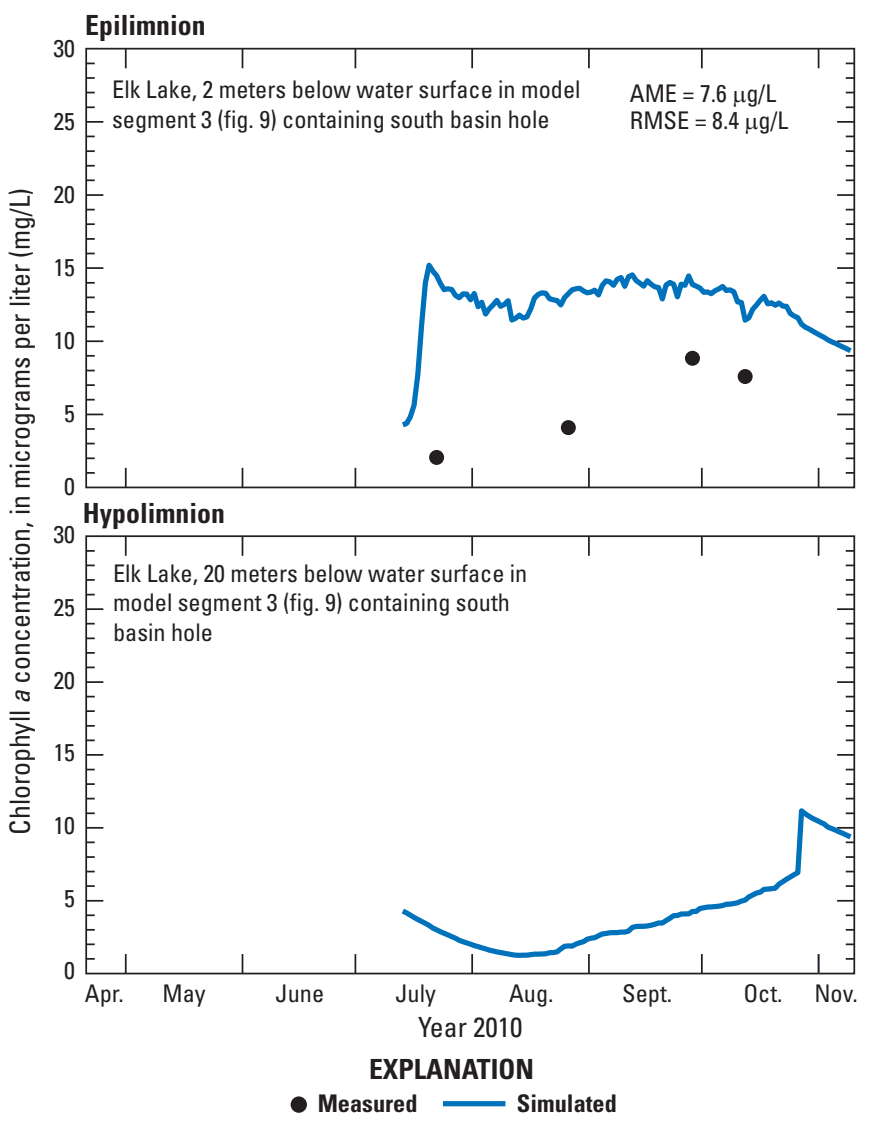

Figure 54. Simulated and measured chlorophyll $a$ concentrations for two depths at the south basin hole in Elk Lake, July 13,2010 , to November 9, 2010, with quantities of absolute mean error (AME) and root mean square error (RMSE).

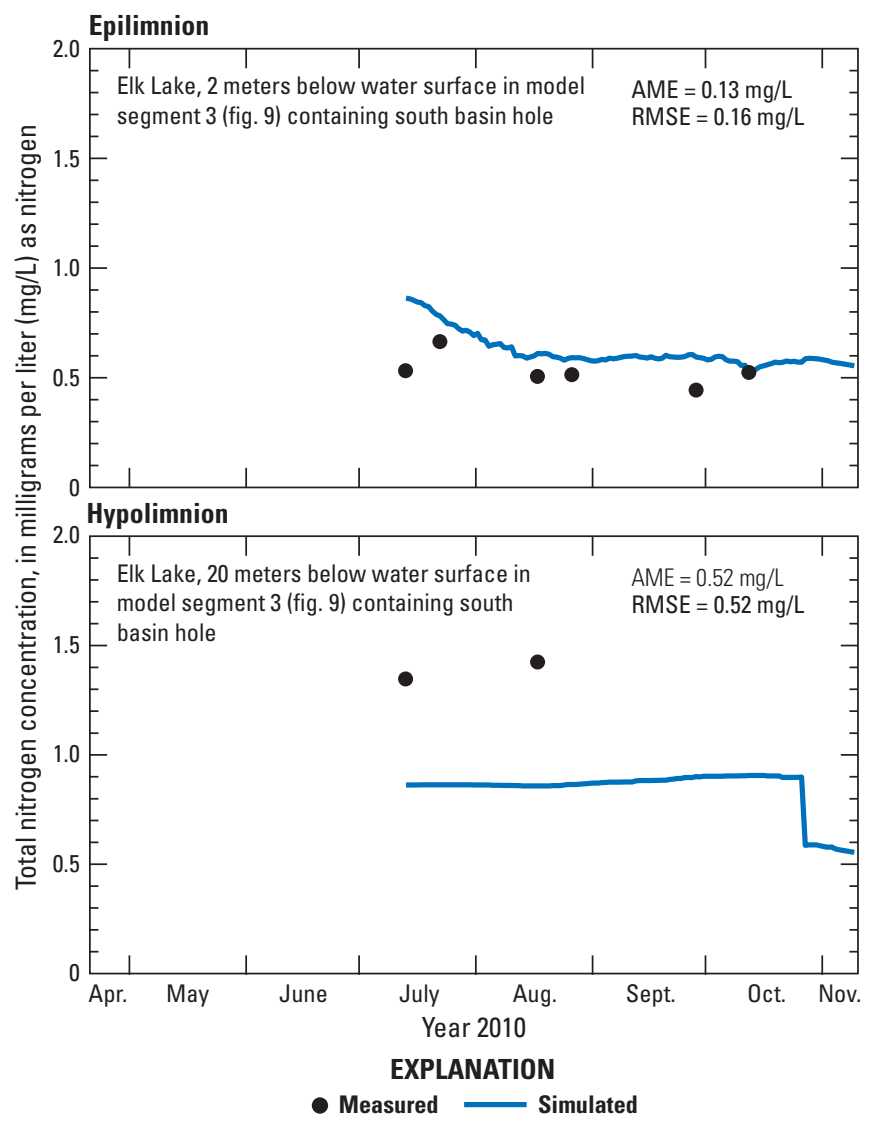

Figure 55. Simulated and measured total nitrogen concentrations for two depths at the south basin hole in Elk Lake, July 13,2010 , to November 9, 2010, with quantities of absolute mean error (AME) and root mean square error (RMSE). 


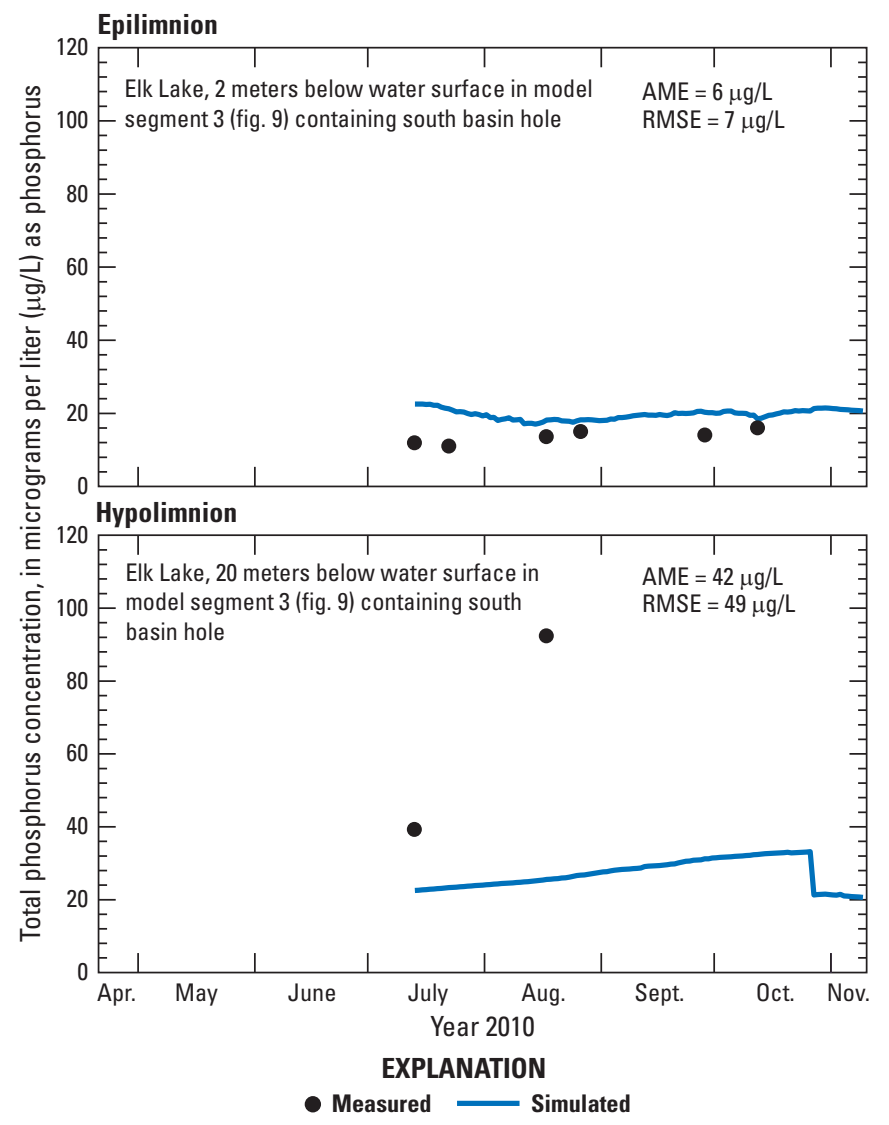

Figure 56. Simulated and measured total phosphorus concentrations for two depths at the south basin hole in Elk Lake, July 13,2010 , to November 9,2010 , with quantities of absolute mean error (AME) and root mean square error (RMSE).

\section{Trout Lake}

The validated model for Trout Lake was run for two separate periods: May 19, 2011, to July 20, 2011, and September 8, 2011, to November 9, 2011. A loss of the pressure transducer data at the Trout Lake outlet during the gap limited the model validation to this shortened period. As in the model validation for Elk Lake, the abridged period for Trout Lake still offered a timeframe to evaluate the robustness of the model under different meteorological and hydrologic conditions.

Simulated water temperatures for Trout Lake were compared to measured lake profile data collected at the north basin hole for six dates for the model validation (fig. 57). The model validation for Trout Lake did not perform as well as the validations for Lake Carlos and Elk Lake when compared to the measured profile data. A fairly large discrepancy occurred for May 24, 2011, when the simulated results predicted a much shallower thermocline than the measured thermocline. This discrepancy seems to have been remedied for the next comparison 2 weeks later, so it is likely that the simulation is slightly out-of-sync with the measured values. Overall, the
AME values ranged from $0.12{ }^{\circ} \mathrm{C}$ to $2.30^{\circ} \mathrm{C}$, and the RMSE values ranged from $0.15^{\circ} \mathrm{C}$ to $2.76^{\circ} \mathrm{C}$.

As in the model calibration, the principal calibration targets for DO for the model validation were the lake profile data collected at the north basin hole. Comparisons between simulated and measured DO concentrations are shown for nine dates in figure 58. Overall, agreement between simulated and measured DO concentrations (fig. 58) was better for the model validation than model calibration (fig. 23). The linear downward trend in hypolimnion DO concentrations was approximated by the model (September 8, 2011; October 12, 2011); however, the model did overestimate the hypolimnetic DO concentrations at depth on June 30, 2011 and July 13, 2011. The AME values for the 9 dates ranged from 0.11 to $0.92 \mathrm{mg} / \mathrm{L}$, and the RMSE values ranged from 0.15 to $2.12 \mathrm{mg} / \mathrm{L}$.

Measured and simulated concentrations for total nitrogen (fig. 59) and total phosphorus (fig. 60) are shown for the same depths at the north basin hole as used for model calibration (figs. 43 and 44). For total nitrogen, the simulated results for the epilimnion (1-m depth) compared favorably to measured concentrations with the exception of one measured high value. The AME and RMSE values for total nitrogen were 0.11 and $0.16 \mathrm{mg} / \mathrm{L}$, respectively (fig. 59; table 6). Only one measured total nitrogen concentration was available for the hypolimnion (18-m depth), which was overestimated in the simulated results. For total phosphorus, the simulated results for the epilimnion were consistently overestimated (fig. 60; table 6), although this was expected because the model calibration had the same issue (fig. 44; table 5). The AME and RMSE values for the epilimnion for total phosphorus were both $5 \mu \mathrm{g} / \mathrm{L}$. The AME and RMSE values for the hypolimnion for total phosphorus were 6 and $7 \mu \mathrm{g} / \mathrm{L}$, respectively.

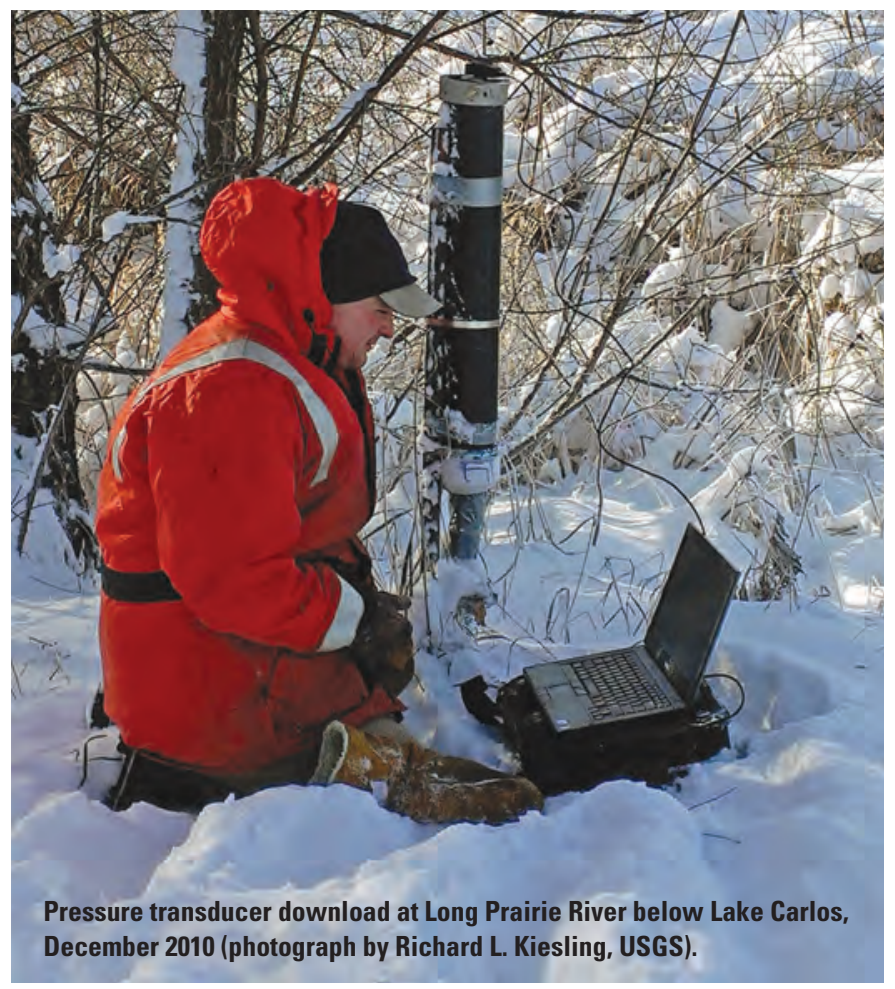




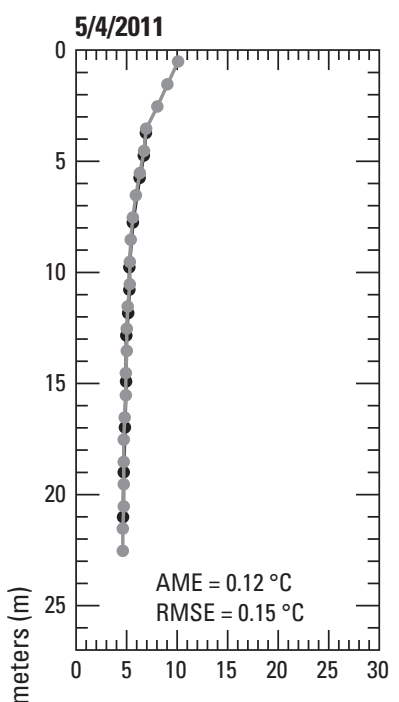

\section{$5 / 11 / 2011$}

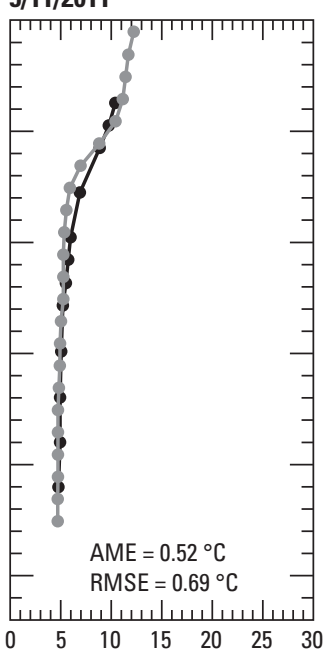

. $7 / 6 / 2011$

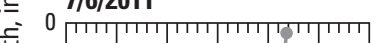

言

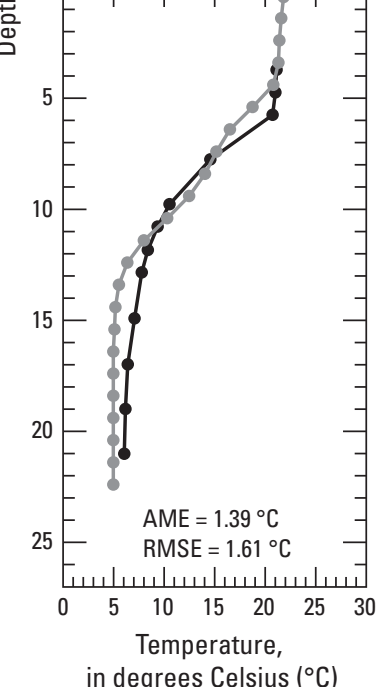

in degrees Celsius $\left({ }^{\circ} \mathrm{C}\right)$
$5 / 24 / 2011$

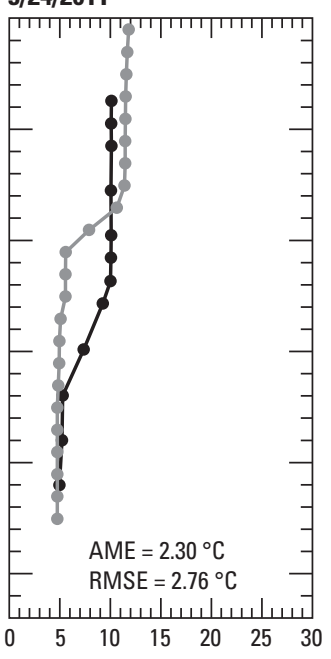

6/8/2011

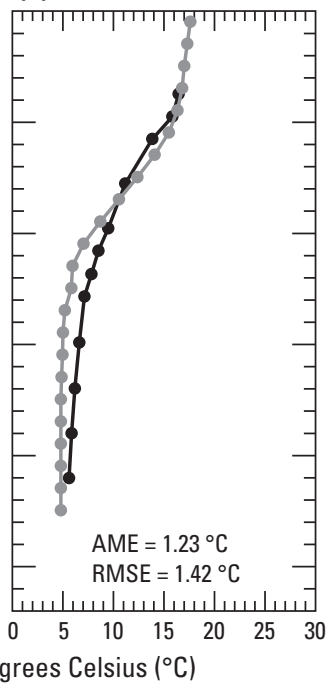

6/21/2011

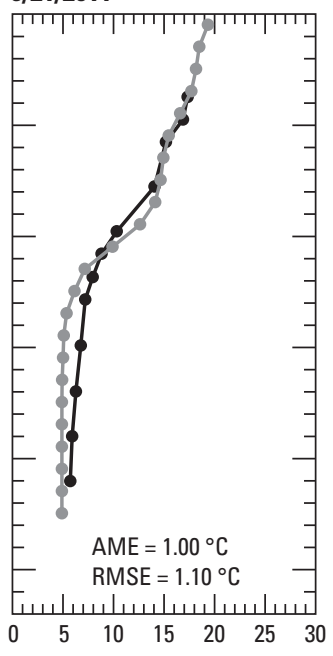

\section{EXPLANATION}

$\longrightarrow$ Measured $\longrightarrow$ Simulated

Figure 57. Simulated and measured water temperature at the north basin hole in Trout Lake for six dates in 2011, with quantities of absolute mean error (AME) and root mean square error (RMSE). 


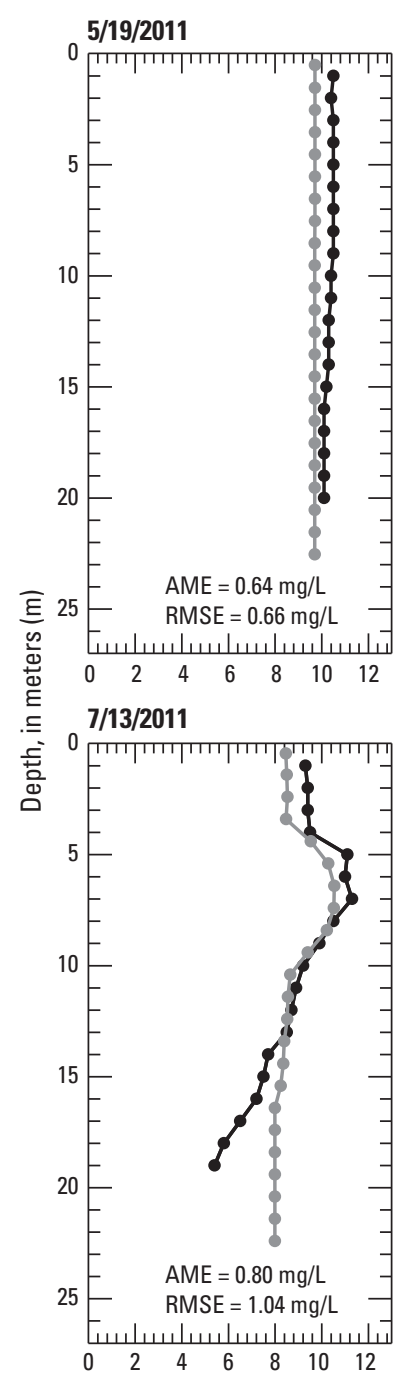

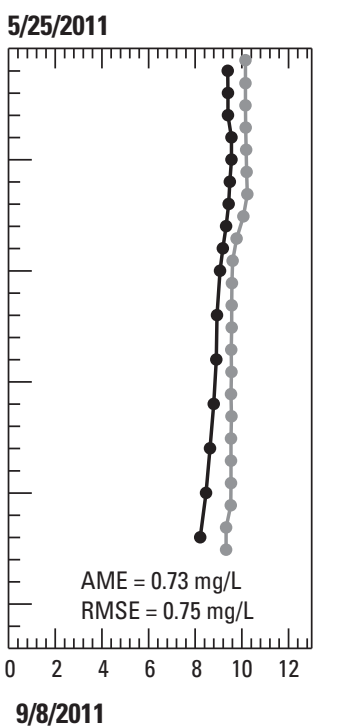
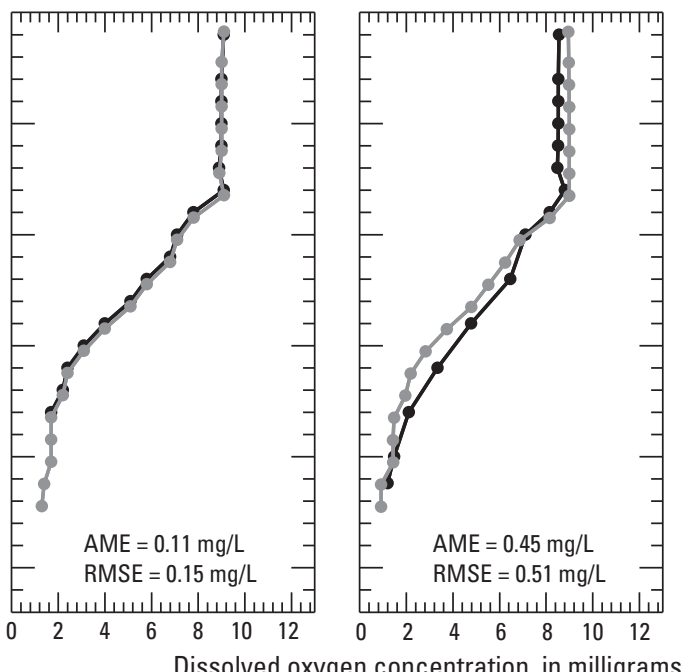

\section{6/1/2011}

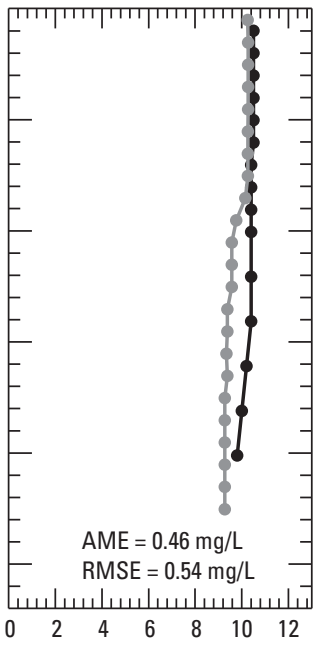

6/14/2011

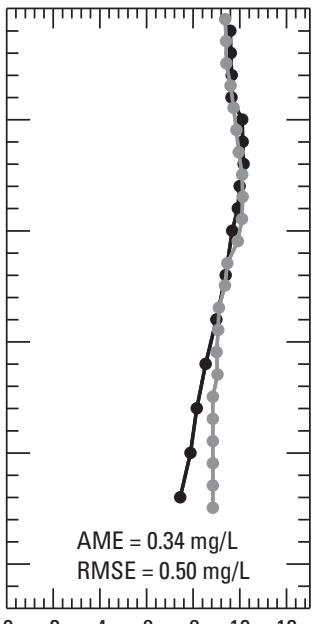

9/13/2011

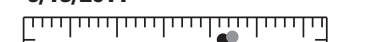

$10 / 12 / 2011$

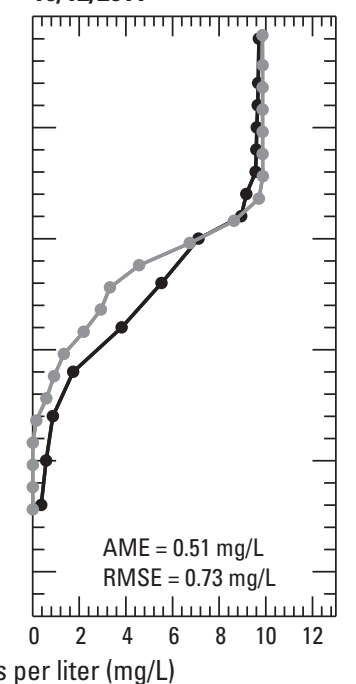

6/30/2011

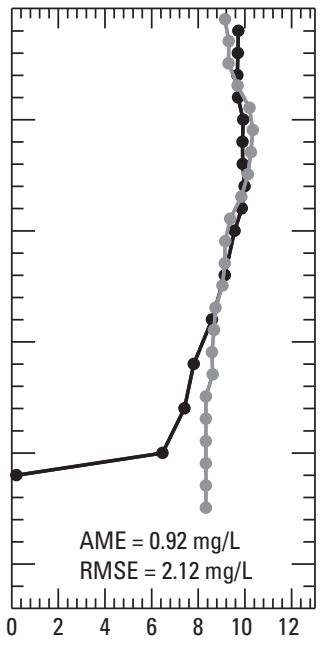

EXPLANATION

$\longrightarrow$ Measured $\longrightarrow$ Simulated

Figure 58. Simulated and measured dissolved oxygen concentration at the north basin hole in Trout Lake for nine dates in 2011, with quantities of absolute mean error (AME) and root mean square error (RMSE). 


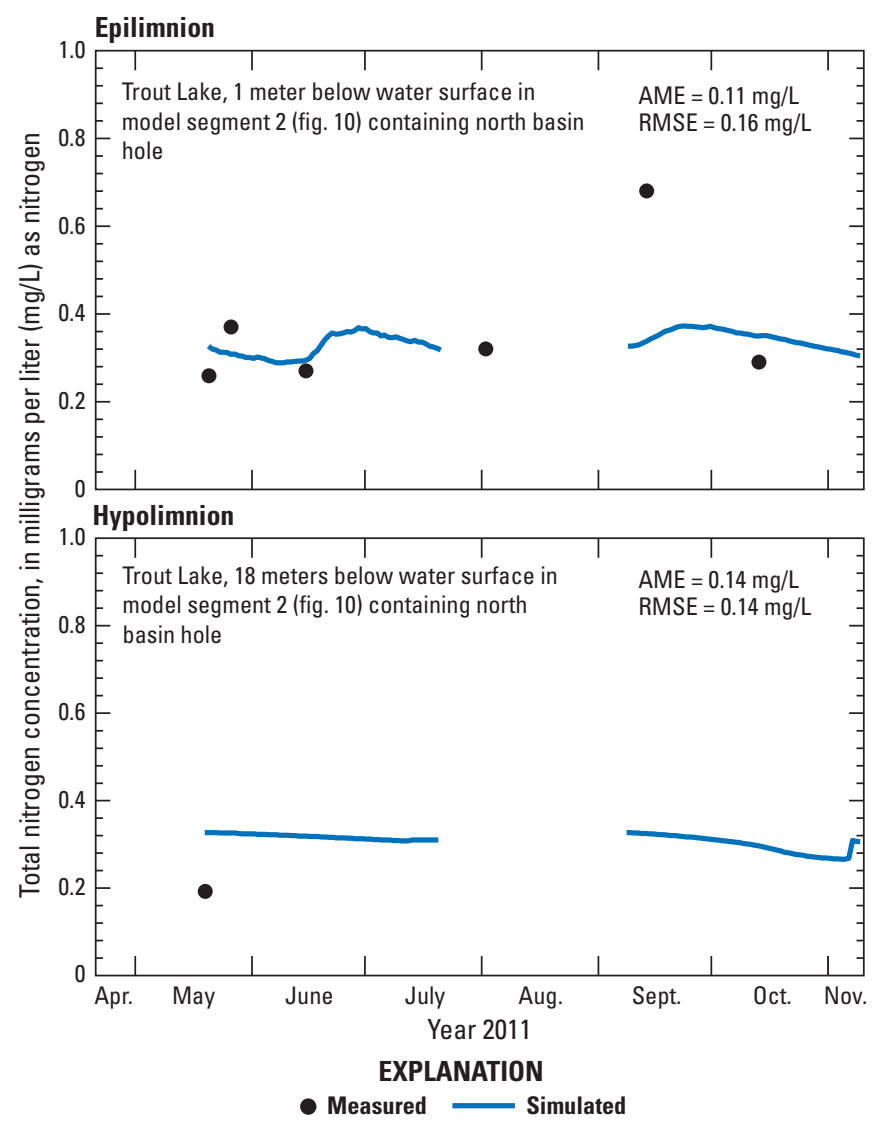

Figure 59. Simulated and measured total nitrogen concentrations for two depths at the north basin hole in Trout Lake, May 19, 2011, to July 20, 2011, and September 8, 2011, to November 9, 2011.

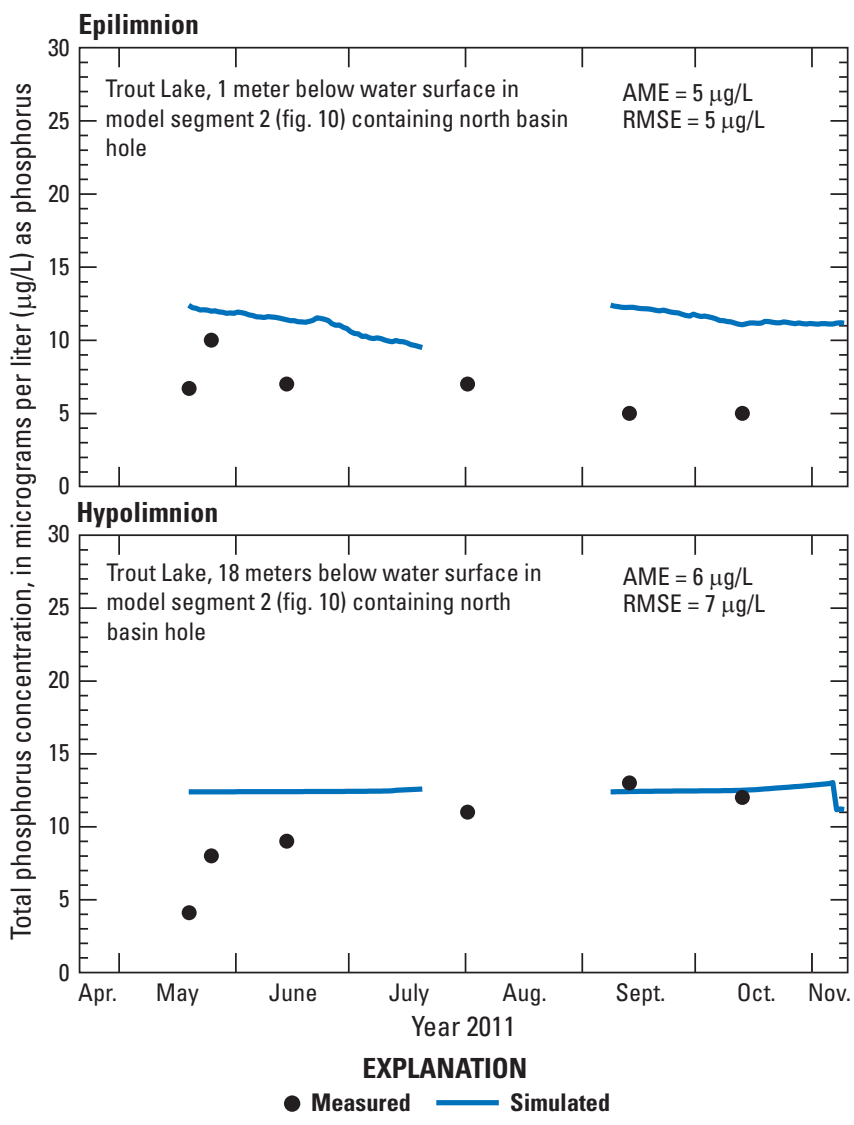

Figure 60. Simulated and measured total phosphorus concentrations for two depths at the north basin hole in Trout Lake, May 19, 2011, to July 20, 2011, and September 8, 2011, to November 9, 2011.

represent a dynamic system. Specific water-quality modules with shortcomings for the CE-QUAL-W2 model include the sediment oxygen demand (SOD), which is user-defined and is decoupled from the water column; SOD variation only occurs with temperature. A complete sediment diagenesis model, with a fully integrated sediment kinetics and the sedimentwater interface, does not currently exist within CE-QUAL-W2 v. 3.6. The macrophyte and zooplankton modules were also not included because of sparse data; instead, the effects of macrophytes and zooplankton were accounted for within the parameterization scheme of SOD and the algal dynamics as an attempt to address this deficiency.

Not only do data limitations exist, but structural selections such as segment geometry, the number of vertical layers, and the numerical transport scheme can potentially impose a bias in the model's outcome. Boundary conditions are not fixed in nature; however, boundary conditions are limited by the availability of data. In addition, extrapolation of the data was necessary to fit the requirements of the CE-QUALW2 model. For example, water-quality data were linearly (2008). Also, recognition must be made of the inher shortcomings of a fixed number of water-quality samples to 
interpolated between sampling dates, or the sampling data were used as input into load-estimation software to generate daily time steps for the model. Gaps within the continuous record also caused shorter calibration and validation periods than desired. As an example, Trout Lake outlet was limited for the 2011 validation period because of the loss of water-level transducer data during the summer months, thereby splitting the validation period into two sections rather than one continuous validation.

\section{Sensitivity Analysis}

A sensitivity analysis was completed to understand the effects on the model results of controlled departures in the calibrated model parameters and input loads. Because of the numerous calibrated parameters in each of the three lake models (table 4), only six different constituents were altered in the sensitivity analysis. For each of the following parameters or input loads, the calibrated lake model value was increased by 20 percent and decreased by 20 percent: wind sheltering coefficient, inflow phosphorus, inflow nitrogen, inflow organic matter, SOD, and the extinction coefficient. In the case of the extinction coefficient, all of the component light extinction coefficients were adjusted including the light extinction coefficients for pure water (parameter EXH20, table 4), inorganic suspended solids (parameter EXSS, table 4), organic suspended solids (parameter EXOM, table 4), and the three different algal groups (diatoms [parameter EXA1, table 4], green [parameter EXA2, table 4], and blue-green [parameter EXA3, table 4]). During model development and calibration, a more robust but less controlled sensitivity analysis was undertaken in each of the three lake models in order to attain a final calibrated model, meaning that more than the six different constituents underwent sensitivity analysis. However, the six constituents chosen for this analysis were found to be some of the most sensitive parameters or input loads, as well as in previous CE-QUAL-W2 lake models (Green and others, 2003; Sullivan and Rounds, 2005; Galloway and Green, 2006; Galloway and others, 2008). Vertical profiles (at 1-m intervals) of water temperature and concentrations of $\mathrm{DO}$, ammonia, nitrate plus nitrite, orthophosphorus, and chlorophyll $a$ were compared for Kecks Point for Lake Carlos, the south basin hole for Elk Lake, and the north basin hole for Trout Lake. Results are presented as the percent change from the calibrated value (table 7).

Water temperature in the Lake Carlos and Elk Lake models was most sensitive to alterations in the wind sheltering coefficient, whereas the coefficient had only a small effect on water temperature in the Trout Lake model. Because the wind sheltering coefficient adjusts the resultant wind speed, this will affect the amount of mixing that occurs in the vertical dimension and thereby the depth of the thermocline over time. Decreases in the wind sheltering coefficient will result in lower wind speeds and lead to a shallower thermocline and higher water temperatures at the lake surface. Increases in the wind sheltering coefficient will result in greater wind speeds and lead to a deeper thermocline and lower water temperatures at the lake surface. In comparing the three lakes for the effect of the wind sheltering coefficient on water temperature, it was found that the larger the lake, the more sensitive the water temperature is to alterations in the wind sheltering coefficient. However, care must be taken to generalize this effect, as this analysis only includes the three selected lakes, and this is more likely an illustration of the importance of collecting wind speed and direction close to the lake, especially for larger lakes. The only other parameter with a substantial effect on water temperature was the extinction coefficient. The strongest departures were observed in Trout Lake, but with only a 3 percent change when the extinction coefficient was decreased by 20 percent.

Dissolved oxygen in the Lake Carlos and Elk Lake models also was most sensitive to alterations in the wind sheltering and extinction coefficients. DO changes are strongly tied to water temperature dynamics, hence, the connection between water temperature and DO sensitivity. This also explains the smaller sensitivity in DO for Trout Lake, which had a minor departure for water temperature and DO in response to the wind sheltering coefficient. For the Lake Carlos and Elk Lake models, SOD is a major sink for DO, so departures in this parameter (parameter SOD, table 4) also had a strong effect. SOD is smaller in Trout Lake; therefore, the effect on DO is smaller.

Unlike water temperature and DO, nutrient concentrations were affected by several parameters or input loads (table 7). For Lake Carlos, ammonia was most affected by the wind sheltering coefficient and SOD. Because of the larger size of Lake Carlos compared to the other two lakes, changes in the input loads (phosphorus, nitrogen, organic matter) only had a small effect. The likely connection to the wind sheltering coefficient relates to the water temperature, which will affect the timing and magnitude of algal growth for the three different algal groups. Because the algal dynamics affect the ammonia concentrations during photosynthesis (uptake) and respiration (release), the effect of wind on water temperature will thereby affect algal growth and production. This also explains the same patterns of ammonia concentrations for Elk Lake and Trout Lake. Small perturbations in the ammonia concentrations were seen for changes in the input loads, although these effects were minor because of the size of the lake volume relative to the incoming load. SOD also affects the ammonia concentration by governing the rate at which bacteria and other organisms metabolize organic matter, which will eventually release ammonia back into the water column. Nitrate plus nitrite and orthophosphorus concentrations also were affected for the same reasons as ammonia, with a strong tie to factors that control algal dynamics. The percent differences vary between ammonia, nitrate plus nitrite, and orthophosphorus; however, the trends are the same with the exception of the SOD (table 7). Another departure from the above pattern occurs for orthophosphorus. Because orthophosphorus 
Table 7. Sensitivity analysis for the three separate lake models, in percent change from the calibration run.

[mg/L, milligrams per liter; $\mu \mathrm{g} / \mathrm{L}$, micrograms per liter]

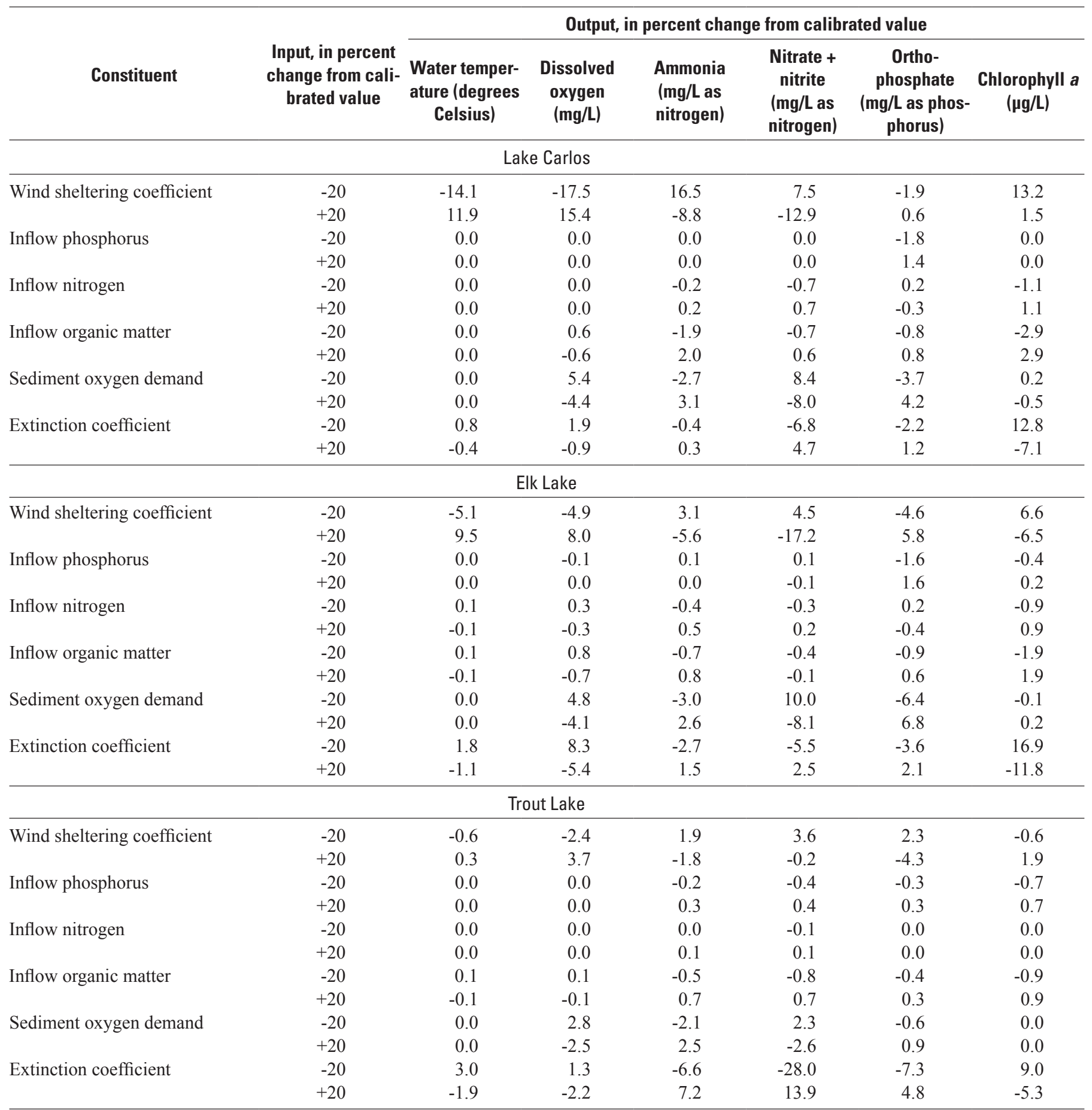


has a relatively small reservoir pool, alterations in the inflow phosphorus also had a minor effect on the orthophosphorus concentrations.

Chlorophyll $a$ is used as a surrogate for algal concentrations, so parameters with a strong effect on algal growth will affect chlorophyll $a$ concentrations. Wind sheltering coefficient had an effect on chlorophyll $a$ concentrations in all three lakes because of the tie to water temperature on algal growth dynamics. In Lake Carlos and Elk Lake, decreasing the wind sheltering coefficient caused the chlorophyll $a$ concentration to increase, which shifted the temperature regime towards enhanced production for the three algal groups; whereas increasing the wind sheltering coefficient caused a negative or smaller positive response in chlorophyll $a$ concentrations. In Trout Lake, the linkage between the wind sheltering coefficient and a change in the chlorophyll $a$ concentration was weak. The extinction coefficient also is important because the penetration of light into the water column will have a strong effect on photosynthetic rates for algal growth dynamics.

Finally, because the incoming loads of phosphorus and nitrogen are relatively low for all three lakes, only the inflow organic matter had a strong effect on algal growth. Because the organic matter pool is large, the eventual breakdown of the organic matter will lead to larger ammonia, nitrate plus nitrite, and orthophosphorus pools, which in turn will lead to increased algal growth. Alternatively, a decrease in the inflow organic matter will have the opposite effect.

\section{Summary}

In recent years, water-resource scientists have been making the case for focused assessments and monitoring of sentinel systems to address how these stress agents change lakes over the long term. Currently in Minnesota, a large-scale effort called "Sustaining Lakes in a Changing Environment" is underway that includes a focus on monitoring basic watershed, water quality, habitat, and fish indicators of 24 Minnesota sentinel lakes across a gradient of ecoregions, depths, and nutrient levels. As part of this effort, the U.S. Geological Survey, in cooperation with the Minnesota Department of Natural Resources, developed predictive water-quality models to assess water quality and habitat dynamics of three select deepwater lakes in Minnesota. The three lakes (Lake Carlos in Douglas County, Elk Lake in Clearwater County, and Trout Lake in Cook County) were assessed under recent (2010-11) meteorological conditions. The three selected lakes contain deep, coldwater habitats that remain viable during the summer months for coldwater fish species.

Hydrodynamics and water-quality characteristics for each of the three lakes were simulated using the CE-QUAL-W2 model, which is a carbon-based, laterally averaged, twodimensional water-quality model. The CE-QUAL-W2 models address the interaction between nutrient cycling, primary production, and trophic dynamics to predict responses in the distribution of temperature and oxygen in lakes. Adjustments to the water balance were made through changes to the gains and losses in the distributed tributary flow, which lumps all ungaged inflow and groundwater interactions together in one value. Within the CE-QUAL-W2 model, the distributed tributary flow could be positive or negative, and several iterations were completed before the water balance of the model was re-established. Before the temperature and water-quality calibration could proceed, the differences between the simulated and measured water-surface elevations was rectified. A water balance was considered complete when the absolute mean error and root mean square error quantities were less than 0.01 meter for the simulated water-surface elevation.

The Lake Carlos model was calibrated using data collected from April through November 2010 including vertical profiles of water temperature and dissolved oxygen concentration at a deep location in the northern part of Lake Carlos, and water-quality constituent concentrations collected in the epilimnion and hypolimnion at the same site. The calibrated model was validated with data collected from March through September 2011. The Elk Lake model was calibrated using data collected from April through November 2011 including vertical profiles of water temperature and dissolved oxygen concentration at a deep location in the southern part of Elk Lake, and water-quality constituent concentrations collected in the epilimnion and hypolimnion at the same site. The calibrated model was validated with data collected from July through November 2010. The Trout Lake model was calibrated using data collected from April through October 2010 including vertical profiles of water temperature and dissolved oxygen concentration at a deep location in the northeastern part of Trout Lake, and water-quality constituent concentrations collected in the epilimnion and hypolimnion at the same site. The calibrated Trout Lake model was validated with data collected during two separate periods from May through November 2011.

Simulation results indicated that the model adequately predicted the seasonal dynamics of physical and chemical parameters, including vertical profiles of water temperature and dissolved oxygen concentration as well as nutrient concentrations in the epilimnion and the hypolimnion. This high level of model performance was repeated throughout the three lake simulations. The CE-QUAL-W2 models for all three lakes successfully predicted water temperature, on the basis of the two metrics of absolute mean error and root mean square error, using measured inputs of water temperature and nutrients. One of the main calibration tools for CE-QUALW2 model development was the vertical profile temperature data, available for all three lakes. For all three lakes, the absolute mean error and root mean square error were less than 1.0 degree Celsius and 1.2 degrees Celsius, respectively, for the different depth ranges used for vertical profile comparisons. In Lake Carlos, simulated water temperatures compared better to measured water temperatures in the epilimnion than in the hypolimnion. The reverse was true for the other two lakes, Elk Lake and Trout Lake, where the simulated results 
were slightly better for the hypolimnion than the epilimnion. The model also was used to approximate the location of the thermocline throughout the simulation periods, approximately April to November, in all three lake models. Deviations between the simulated and measured water temperatures in the vertical lake profile commonly were because of an offset in the timing of thermocline shifts rather than the simulated results missing thermocline shifts altogether. A secondary water-temperature calibration tool was the continuous water-temperature records available for all of the primary outlets of each lake, such as the Long Prairie River in the case of Lake Carlos. Given that these continuous records indicate the temperature of shallow water leaving the lake, not of the lake itself, it was not surprising that the offset between simulated and measured results was larger than for the vertical temperature profiles of the lakes. Also, the absolute mean error and root mean square error are reported for temperatures of the primary outlets, but more importantly these comparisons were used more for the trend rather than the absolute calibration.

In addition to water temperature, the CE-QUAL-W2 models for all three lakes successfully predicted dissolved oxygen concentration based on the two metrics of absolute mean error and root mean square error. Simulated dissolved oxygen concentration generally tracked the measured dissolved oxygen concentration for the calibration and validation periods. Simulated vertical profiles of dissolved oxygen concentration generally matched the largest change in measured dissolved oxygen concentration, including the approximate depth, slope, and timing of large shifts. Specific examples of the model capabilities included comparisons between simulated and measured vertical profile data for the metalimnetic oxygen minimums for Lake Carlos and midwater column oxygen maximum for Elk Lake.

The ability of the model to simulate the physical and chemical components of lake ecosystem response went beyond the accurate tracking of vertical profiles from a specific date. The model also captured the trajectories of water temperature and dissolved oxygen concentration over time at multiple depths. This indicates that the model was accurately simulating the underlying metabolic processes in each lake. For Lake Carlos, the simulated dissolved oxygen concentration in the metalimnion tracked the dissolved oxygen concentration minimum by accurately simulating the oxygen demand associated with decomposition of algal carbon below the photic zone. In Elk Lake, the simulated metalimnetic chlorophyll maximum matched the measured metalimnetic oxygen maximum. In both cases, simulated in-lake processes of primary production, algal mortality, and carbon and nutrient recycling matched the measured dissolved oxygen dynamics. Both cases illustrate that the internal trophic dynamics in these deep, coldwater lakes are important factors controlling much of the observed biogeochemistry.

Boundary factors, such as topography and shoreline tree cover, can have a profound effect on wind mixing. Wind effects from these boundary factors were indirectly augmented through the wind sheltering coefficient. The assigned wind sheltering coefficient was found to be a sensitive parameter, which affected the amount of mixing that occurred in the vertical dimension and thereby the depth of the thermocline over time.

Algal dynamics were captured by three general groups: (1) diatoms, (2) green algae, and (3) blue-green algae. Simulated algal-growth temperature coefficients were consistent across all three lakes, in addition to the algal-growth rates and the light saturation intensity at the maximum photosynthetic rate. The focus for evaluating water quality included three constituents of nitrogen and two constituents of phosphorus: nitrate plus nitrite, ammonia, total nitrogen, orthophosphorus, and total phosphorus. Ammonia, nitrate plus nitrite, and orthophosphorus concentrations in all three lakes were largely affected by the inflows and the lake hydrodynamics; in general, the simulated concentrations compared well to the measured data. Simulated total nitrogen and total phosphorus concentrations did not compare as well to measured data, particularly in the hypolimnion.

\section{References Cited}

Ameel, John, Ruzycki, Elaine, and Axler, R.P., 1998, Analytical chemistry and quality assurance procedures for natural water samples, (6th ed.): Central Analytical Laboratory, Natural Resources Research Institute Technical Report NRRI/TR-98/03 revised annually.

Anderson, R.Y., Bradbury, J.P., Dean, W.E., and Stuiver, Minze, 1993, Chronology of Elk Lake sediments - Coring, sampling, and time-series construction, in Bradbury, J.P., and Dean, W.E., eds., Elk Lake, Minnesota—Evidence for rapid climate change in the north-central United States: Boulder, Colorado, Geological Society of America Special Paper 276, p. 135-158. (Also available at $h t t p: / / d x . d o i$. org/10.1130/SPE276-p37.)

Arar, E.J., 1997, Method 446.0 - In vitro determination of chlorophylls $a, b, c_{1}+c_{2}$ and pheopigments in marine and freshwater algae by visible spectrophotometry: Cincinnati, Ohio, National Exposure Research Laboratory, Office of Research and Development, U.S. Environmental Protection Agency Report EPA-446.0-1, 26 p.

Bradbury, J.P., and Dieterich-Rurup, K.V., 1993, Holocene diatom paleolimnology of Elk Lake, Minnesota, in Bradbury, J.P., and Dean, W.E., eds., Elk Lake, Minnesota-Evidence for rapid climate change in the north-central United States: Boulder, Colorado, Geological Society of America Special Paper 276, p. 215-238. (Also available at http:// dx.doi.org/10.1130/SPE276-p215.) 
Brunett, J.O., Barber, N.L., Burns, A.W., Fogelman, R.P., Gillies, D.C., Lidwin, R.A., and Mack, T.J., 1997, A qualityassurance plan for district ground-water activities of the U.S. Geological Survey: U.S. Geological Survey Open-File Report 97-11, 44 p. (Also available at http://water.usgs.gov/ ogw/pubs/OFR9711/.)

Buchanan, T.J., and Somers, W.P., 1969, Discharge measurements at gaging stations: U.S. Geological Survey Techniques of Water-Resources Investigations, book 3, chap. A8, 71 p. (Also available at $h t t p: / / p u b s . u s g s . g o v / t w r i / t w r i 3 a 8 /$.)

Carpenter, S.R., Benson, B.J., Biggs, Reinette, Chipman, J.W., Foley, J.A., Golding, S.A., Hammer, R.B., Hanson, P.C., Johnson, P.T.J., Kamarainen, A.M., Kratz, T.K., Lathrop, R.C., McMahon, K.D., Provencher, Bill, Rusak, J.A., and others, 2007, Understanding regional change-A comparison of two lake districts: BioScience, v. 57, no. 4, p. 323-335. (Also available at $h t t p: / / d x$.doi.org/10.1641/ B570407.)

Childress, C.J.O., Foreman, W.T., Connor, B.F., and Maloney, T.J., 1999, New reporting procedures based on longterm method detection levels and some considerations for interpretations of water-quality data provided by the U.S. Geological Survey National Water Quality Laboratory: U.S. Geological Survey Open-File Report 99-193, 19 p. (Also available at http://pubs.er.usgs.gov/publication/ofr99193.)

Cohn, T.A., Caulder, D.L., Gilroy, E.J., Zynjuk, L.D., and Summers, R.M., 1992, The validity of a simple log-linear model for estimating fluvial constituent loads-An empirical study involving nutrient loads entering Chesapeake Bay: Water Resources Research, v. 28, no. 9, p. 2353-2363. (Also available at $h t t p: / / d x$.doi.org/10.1029/92WR01008.)

Cole, T.M., and Wells, S.A., 2008, CE-QUAL-W2-A twodimensional, laterally averaged, hydrodynamic and water quality model, version 3.6: U.S. Army Corps of Engineers Instruction Report EL-08-1, 715 p.

Dean, W.E., 1993, Physical properties, mineralogy, and geochemistry of Holocene varved sediments from Elk Lake, Minnesota, in Bradbury, J.P., and Dean, W.E., eds., Elk Lake, Minnesota - Evidence for rapid climate change in the north-central United States: Boulder, Colorado, Geological Society of America Special Paper 276, p. 135-158. (Also available at $h t t p: / / d x$.doi.org/10.1130/SPE276-p135.)

De Stasio, B.T., Jr., Hill, D.K., Klienhans, J.M., Nibbelink, N.P., and Magnuson, J.J., 1996, Potential effects of global climate change on small north-temperate lakes-Physics, fish, and plankton: Limnology and Oceanography, v. 41, no. 5, p. 1136-1149. (Also available at http://www.jstor.org/ stable/2838806.)
Fang, Xing, and Stefan, H.G., 1999, Projections of climate change effects on water temperature characteristics of small lakes in the contiguous U.S.: Climatic Change, v. 42 , no. 2 , p. 377-412.

Fang, Xing, Jiang, Liping, Jacobson, P.C., Stefan, H.G., Alam, S.R., and Pereira, D.L., 2012, Identifying cisco refuge lakes in Minnesota under future climate scenarios: Transactions of the American Fisheries Society, v. 141, p. 1608-1621. (Also available at $h t t p: / / d x$.doi.org/10.1080/00028487.2012 .713888 .)

Fang, Xing, Stefan, H.G., Eaton, J.G., McCormick, J.H., and Alam, S.R., 2004a, Simulation of thermal/dissolved oxygen habitat for fishes in lakes under different climate scenarios-Part 1. Cool-water fish in the contiguous US: Ecological Modelling, v. 172, no. 1, p. 13-37. (Also available at http://dx.doi.org/10.1016/S0304-3800(03)00282-5.)

Fang, Xing, Stefan, H.G., Eaton, J.G., McCormick, J.H., and Alam, S.R., 2004b, Simulation of thermal/dissolved oxygen habitat for fishes in lakes under different climate scenarios-Part 2. Cold-water fish in the contiguous US: Ecological Modelling, v. 172, no. 1, p. 39-54. (Also available at http://dx.doi.org/10.1016/S0304-3800(03)00285-0.)

Fishman, M.J., ed., 1993, Methods of analysis by the U.S. Geological Survey National Water Quality LaboratoryDetermination of inorganic and organic constituents in water and fluvial sediments: U.S. Geological Survey OpenFile Report 93-125, 217 p. (Also available at $h t t p: / / p u b s$. er.usgs.gov/publication/ofr 93125 .)

Fishman, M.J., and Friedman, L.C., eds., 1989, Methods for determination of inorganic substances in water and fluvial sediments: U.S. Geological Survey Techniques of WaterResource Investigation 05-A1, 545 p. (Also available at http://pubs.er.usgs.gov/publication/twri05A1.)

Flowers, J.D., Hauck, L.M., and Kiesling, R.L., 2001, USDA Lake Waco-Bosque River Initiative-Water quality modeling of Lake Waco using CE-QUAL-W2 for assessment of phosphorus control strategies: Texas Institute for Applied Environmental Research TR0114, 73 p.

Galloway, J.M., and Green, W.R., 2006, Application of a twodimensional reservoir water-quality model of Beaver Lake, Arkansas, for the evaluation of simulated changes in input water quality, 2001-2003: U.S. Geological Survey Scientific Investigations Report 2006-5302, 39 p. (Also available at $h t t p: / / p u b s . u s g s . g o v /$ sir/2006/5302/.)

Galloway, J.M., Ortiz, R.F., Bales, J.D., and Mau, D.P., 2008, Simulation of hydrodynamics and water quality in Pueblo Reservoir, southeastern Colorado, for 1985 through 1987 and 1999 through 2002: U.S. Geological Survey Scientific Investigations Report 2008-5056, 67 p. (Also available at http://pubs.usgs.gov/sir/2008/5056/.) 
Gibs, Jacob, Wilde, F.D., and Heckathorn, H.A., 2012, Use of multiparameter instruments for routine field measurements: U.S. Geological Survey Techniques of Water-Resources Investigations, book 9, chap. A6., sec. 6.8, March 2012, accessed August 2013, from http://pubs.water.usgs.gov/ twri9A6/.

Green, W.R., Galloway, J.M., Richards, J.M., and Wesolowski, E.A., 2003, Simulation of hydrodynamics, temperature, and dissolved oxygen in Table Rock Lake, Missouri, 19961997: U.S. Geological Survey Water-Resources Investigations Report 2003-4237, 46 p. (Also available at $h t t p: / /$ pubs.er.usgs.gov/publication/wri034237/.)

Jacobson, P.C., Jones, T.S., Rivers, Pat, and Pereira, D.L., 2008, Field estimation of a lethal oxythermal niche boundary for adult ciscoes in Minnesota lakes: Transactions of the American Fisheries Society, v. 137, no. 5, p. 1464-1474. (Also available at $h t t p: / / d x . d o i . o r g / 10.1577 / T 07-148.1$.

Jassby, A.D., 1998, Interannual variability at three inland water sites-Implications for sentinel ecosystems: Ecological Applications, v. 8, no. 2, p. 277-287. (Also available at http://dx.doi.org/10.1890/1051-0761(1998)008[0277:IVATI W]2.0.CO;2.)

Lind, O.T., 1974, Handbook of common methods in limnology: St. Louis, the C.V. Mosby Company, p. 26-31.

Lindenberg, M.K., Hoilman, Gene, and Wood, T.M., 2008, Water quality conditions in Upper Klamath and Agency Lakes, Oregon, 2006: U.S. Geological Survey Scientific Investigations Report 2008-5201, 66 p. (Also available at http://pubs.usgs.gov/sir/2008/5201/.)

Lorenz, D.L., Sanocki, C.A., and Kocian, M.J., 2009, Techniques for estimating the magnitude and frequency of peak flows on small streams in Minnesota based on data through water year 2005: U.S. Geological Survey Scientific Investigations Report 2009-5250, 62 p. (Also available at http:// pubs.usgs.gov/sir/2009/5250/.)

Magner, J.A., and Brooks, K.N., 2008, Integrating sentinel watershed-systems into the monitoring and assessment of Minnesota's (USA) waters quality: Environmental Monitoring and Assessment, v. 138, no. 1-3, p. 149-158. (Also available at $h t t p: / / d x$.doi.org/10.1007/s10661-007-9752-9.)

Magnuson, J.J., Benson, B.J., and Kratz, T.K., 1990, Temporal coherence in the limnology of a suite of lakes in Wisconsin, U.S.A.: Freshwater Biology, v. 23, p. 145-159. (Also available at $h t t p: / / d x$.doi.org/10.1111/j.1365-2427.1990. tb00259.x.)

McDonald, T.L., 2003, Review of environmental monitoring methods-Survey designs: Environmental Monitoring and Assessment, v. 85, no. 3, p. 277-292. (Also available at http://dx.doi.org/10.1023/A:1023954311636.)
Minnesota Department of Health, 2013, Environmental laboratory sampling and analysis guide: accessed August 19, 2013, at http://www.health.state.mn.us/divs/phl/ environmental/handbook.pdf.

Minnesota Department of Natural Resources, 2010, Sustaining lakes in a changing environment-SLICE: accessed November 20, 2013, at http://files.dnr.state.mn.us/fish_ wildlife/fisheries/slice/rm.pdf.

Minnesota Department of Natural Resources, 2013a, North Shore Highlands subsection: accessed August 19, 2013, at http://www.dnr.state.mn.us/ecs/212Lb/index.html.

Minnesota Department of Natural Resources, 2013b, Minnesota lake watershed delineation (lakeshed) project: accessed August 19, 2013, at http://www.dnr.state.mn.us/watersheds/ lakeshed_project.html.

Minnesota Department of Natural Resources, 2013c, The DNR data deli: accessed August 19, 2013, at http://deli.dnr. state.mn.us/data_catalog.html.

Minnesota Department of Natural Resources, 2013d, Lake finder: accessed August 19, 2013, at http://www.dnr.state. mn.us/lakefind/index.html.

Minnesota Geospatial Information Office, 2013a, Lake bathymetry - Contours: accessed August 19, 2013, at http://www.mngeo.state.mn.us/chouse/water_lakes. html\#Hydrography/Bathymetry.

Minnesota Geospatial Information Office, 2013b, LiDAR elevation data for Minnesota: accessed August 19, 2013, at http://www.mngeo.state.mn.us/chouse/elevation/lidar.html.

Minnesota Pollution Control Agency, 2009a, Sentinel lake assessment report—Lake Carlos (21-0057), Douglas County, Minnesota: accessed August 19, 2013, at http:// files.dnr.state.mn.us/fish_wildlife/fisheries/slice/reports/ wq-2slice21-0057.pdf.

Minnesota Pollution Control Agency, 2009b, Sentinel lakesLake Carlos: accessed August 19, 2013, at http://files. dnr.state.mn.us/fish_wildlife/fisheries/slice/fact-sheets/ wq-slice21-0057.pdf.

Minnesota Pollution Control Agency, 2009c, Sentinel lakes—Elk Lake: accessed August 19, 2013, at http://files. dnr.state.mn.us/fish_wildlife/fisheries/slice/fact-sheets/ wq-slice15-0010.pdf.

Minnesota Pollution Control Agency, 2009d, Sentinel lakes-Trout Lake: accessed August 19, 2013, at http:// files.dnr.state.mn.us/fish_wildlife/fisheries/slice/fact-sheets/ wq-slice16-0049.pdf. 
Minnesota Pollution Control Agency, 2011a, Sentinel lake assessment report_Elk Lake (15-0010), Clearwater County, Minnesota: accessed August 19, 2013, at http://www.pca.state.mn.us/index.php/view-document. html?gid=15919.

Minnesota Pollution Control Agency, 2011b, Sentinel lake assessment report-Trout Lake (16-0049), Cook County, Minnesota: accessed August 19, 2013, at http://www.pca. state.mn.us/index.php/view-document.html? gid $=15772$.

McDonald, T.L., 2003, Review of environmental monitoring methods-Survey designs: Environmental Monitoring and Assessment, v. 85, no. 3, p. 277-292. (Also available at http://dx.doi.org/10.1023/A:1023954311636.)

Mueller, D.S., and Wagner, C.R., 2008, Measuring discharge with acoustic doppler current profilers from a moving boat: U.S. Geological Survey Techniques and Methods, book 3, chap. A22, 86 p. (Also available at http://pubs.usgs.gov/ $\mathrm{tm} / 3 \mathrm{a} 22 /$.)

National Climatic Data Center, 2013, Climate data online: accessed December 19, 2013, at http://www.ncdc.noaa.gov/ cdo.

Nuhfer, E.B., Anderson, R.Y., Bradbury, J.P., and Dean, W.E., 1993, Modern sedimentation in Elk Lake, Clearwater County, Minnesota, in Bradbury, J.P., and Dean, W.E., eds., Elk Lake, Minnesota_Evidence for rapid climate change in the north-central United States: Boulder, Colorado, Geological Society of America Special Papers 276, p. 75-96. (Also available at http://dx.doi.org/10.1130/SPE276-p75.)

Patton, C.J., and Kryskalla, J.R., 2011, Colorimetric determination of nitrate plus nitrite in water by enzymatic reduction, automated discrete analyzer methods: U.S. Geological Survey Techniques and Methods 5-B8, 34 p. (Also available at http://pubs.er.usgs.gov/publication/tm5B8).

Patton, C.J., and Truitt, E.P., 2000, Methods of analysis by the U.S. Geological Survey National Water Quality Laboratory; determination of ammonium plus organic nitrogen by a Kjeldahl digestion method and an automated photometric finish that includes digest cleanup by gas diffusion: U.S. Geological Survey Open-File Report 2000-170, 31 p. (Also available at http://pubs.er.usgs.gov/publication/ofr00170).

Portland State University, 2013, CE-QUAL-W2-Hydrodynamic and water quality model: accessed November 20 , 2013, at http://www.ce.pdx.edu/w2/.

Rantz, S.E., and others, 1982a, Measurement and computation of streamflow, volume 1. Measurement of stage and discharge: U.S. Geological Survey Water-Supply Paper 2175, v. 1, 313 p. (Also available at http://pubs.usgs.gov/ wsp/wsp2175/html/WSP2175_vol1.html.)
Rantz, S.E., and others, 1982b, Measurement and computation of streamflow, volume 2. Computation of discharge: U.S. Geological Survey Water-Supply Paper 2175, v. 2, 373 p. (Also available from http://pubs.usgs.gov/wsp/wsp2175/ html/wsp2175_vol2_pdf.html.)

Ries, K.G., III, Steeves, P.A., Coles, J.D., Rea, A.H., and Stewart, D.W., 2005, StreamStats-A U.S. Geological Survey Web application for stream information: U.S. Geological Survey Fact Sheet 2004-3115, 4 p. (Also available at http://md.water.usgs.gov/publications/fs-2004-3115/.)

Runkel, R.L., Crawford, C.G., and Cohn, T.A., 2004, Load estimator (LOADEST) -A FORTRAN program for estimating constituent loads in streams and rivers: U.S. Geological Survey Techniques and Methods, book 4, chap. A5, 69 p. (Also available at http://pubs.usgs.gov/tm/2005/ tm $4 A 5 /$.

Stefan, H.G., and Fang, Xing, 1994, Dissolved oxygen model for regional lake analysis: Ecological Modelling, v. 71, no. 1-3, p. 37-68. (Also available at http://dx.doi. org/10.1016/0304-3800(94)90075-2.)

Stefan, H.G., Hondzo, Midhat, Eaton, J.G., and McCormick, J.H., 1995, Predicted effects of global climate change on fishes in Minnesota lakes, in Beamish, R.J., ed., Climate change and northern fish populations: Ottawa Canada, National Research Council of Canada, Canadian Special Publication of Fisheries and Aquatic Sciences 121, p. 57-72.

Stefan, H.G., Hondzo, Midhat, and Fang, Xing, Eaton, J.G., and McCormick, J.H., 1996, Simulated long-term temperature and dissolved oxygen characteristics of lakes in the north-central United States and associated fish habitat limits: Limnology and Oceanography, v. 41, no. 5, p. 1124-1135. (Also available at http://www.jstor.org/ stable/2838805.)

Sullivan, A.B., and Rounds, S.A., 2004, Modeling hydrodynamics, temperature, and water quality in Henry Hagg Lake, Oregon, 2000-03: U.S. Geological Survey Scientific Investigations Report 2004-5261, 48 p. (Also available at http://pubs.usgs.gov/sir/2004/5261/.)

Sullivan, A.B., Rounds, S.A., Deas, M.L., Asbill, J.R., Wellman, R.E., Stewart, M.A., Johnston, M.W., and Sogutlugil, I.E., 2011, Modeling hydrodynamics, water temperature, and water quality in the Klamath River upstream of Keno Dam, Oregon, 2006-09: U.S. Geological Survey Scientific Investigations Report 2011-5105, 82 p. (Also available at http://pubs.usgs.gov/sir/2011/5105/.) 
Sullivan, A.B., Rounds, S.A., Sobieszczyk, Steven, and Bragg, H.M., 2007, Modeling hydrodynamics, water temperature, and suspended sediment in Detroit Lake, Oregon: U.S. Geological Survey Scientific Investigations Report 2007-5008, 52 p. (Also available at http://pubs.usgs.gov/ sir/2007/5008/.)

U.S. Environmental Protection Agency, 1993, Method 3651, determination of phosphorus by semi-automated colorimetry, Cincinnati Ohio, $17 \mathrm{p}$.

U.S. Environmental Protection Agency, 2002, Guidelines establishing test procedures for the analysis of pollutants (Part 136, Appendix B. Definition and procedure for the determination of the method detection limit-Revision 1.11): U.S. Code of Federal Regulations, Title 40, revised as of July 1, 2002, p. 635-638.

U.S. Geological Survey, 2013a, National Elevation Dataset: accessed August 19, 2013, at http://ned.usgs.gov/.

U.S. Geological Survey, 2013b, U.S. Geological Survey National Water Information System, water data for Minnesota-Web interface: accessed August 19, 2013, at http:// waterdata.usgs.gov/mn/nwis/nwis.

U.S. Geological Survey, 2013c, Branch of Quality Systems Laboratory Evaluation data and projects: accessed August 19, 2013, at http://bqs.usgs.gov/labEvaluation.php.

Van Dorn, W.G., 1956, Large-volume water-samplers: Transactions, American Geophysical Union, v. 37, no. 6, p. 682-684.

Wagner, R.J., Boulger, R.W., Jr., Oblinger, C.J., and Smith, B.A., 2006, Guidelines and standard procedures for continuous water-quality monitors - Station operation, record computation, and data reporting (ver. 1.0): U.S. Geological Survey Scientific Techniques and Methods 1-D3, $96 \mathrm{p}$. (Also available at $h t t p: / / p u b s . u s g s . g o v / t m / 2006 / t m 1 D 3 /$.
Wetzel, R.G., 2001, Limnology lake and river ecosystems (3d ed.): San Diego, Elsevier, 1,006 p.

Whitlock, Cathy, Bartlein, P.J., and Watts, W.A., 1993, Vegetation history of Elk Lake, in Bradbury, J.P., and Dean, W.E., eds., Elk Lake, Minnesota—Evidence for rapid climate change in the north-central United States: Boulder, Colorado, Geological Society of America Special Paper 276, p. 251-274. (Also available at $h t t p: / / d x . d o i . o r g / 10.1130 /$ SPE276-p251.)

Wilde, F.D., ed., 2004, Cleaning of equipment for water sampling (ver. 2.0): U.S. Geological Survey Techniques of Water-Resources Investigations, book 9, chap. A3, April 2004, accessed January 6, 2014, at http://pubs.water.usgs. gov/twri9A3/.

Wilde, F.D., and Radtke, D.B., 1998, National Field Manual for the collection of water-quality data: U.S. Geological Survey Techniques of Water-Resources Investigations, book 9, chap. A6, various pagination, accessed January 6, 2014, at $h t t p: / / p u b s . w a t e r . u s g s . g o v / t w r i 9 A 6 /$.

Williamson, C.E., Dodds, Walter, Kratz, T.K., and Palmer, M.A., 2008, Lakes and streams as sentinels of environmental change in terrestrial and atmospheric processes: Frontiers in Ecology and the Environment, v. 6, no. 5, p. 247-254. (Also available at $h t t p: / / w w w . j s t o r . o r g / s t a b l e / 20440885$.)

Wright, H.E., Jr., 1993, History of the landscape in the Itasca region, in Bradbury, J.P., and Dean, W.E., eds., Elk Lake, Minnesota-Evidence for rapid climate change in the north-central United States: Boulder, Colorado: Geological Society of America Special Paper 276, p. 7-17. (Also available at $h t t p: / / d x$.doi.org/10.1130/SPE276-p7.) 
Publishing support provided by:

Lafayette, Rolla, and Tacoma Publishing Service Centers

For more information concerning this publication, contact: Director, USGS Minnesota Water Science Center

2280 Woodale Drive

Mounds View, Minnesota 55112

(763) 783-3100

Or visit the Minnesota Water Science Center Web site at: http://mn.water.usgs.gov/ 

